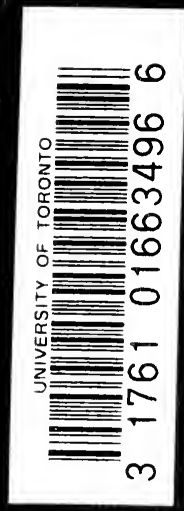


Digitized by the Internet Archive in 2007 with funding from Microsoft Corporation 



\title{
THE BALKANS A LABORATORY OF HISTORY
}

\author{
BY \\ WILLIAM M. SLOANE \\ Member of the American Academy; Professor of History in Columbia University \\ Author The French War and the Revolution; Napoleon Bonaparte: \\ A History; French Revolution and Religious Reform, etc.
}

NEW YORK : EATON \& MAINS CINCINNATI: JENNINGS \& GRAHAM 


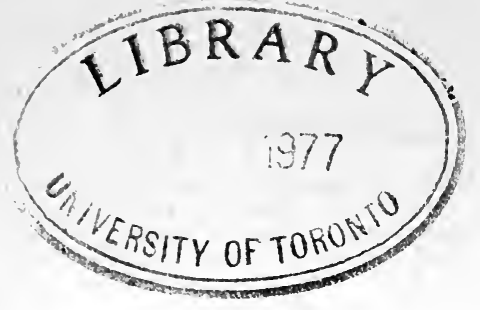

Copyright, 1914, by

WILLIAM M. SLOANE

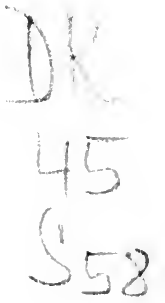




\section{CONTENTS}

\section{Chapter I \\ TURKEY AND EUROPEAN POLITICS}

What is broadly designated as the Balkan peninsula. A racial museum, 3. Fall of the Byzantine empire, 4. Turkish advance checked, 5. Extent of Turkish invasion and rule. Patriciate stripped of dignity and power, 6 . Alternatives offered by victorious Islam, 7. Ottoman, founder of power and fame of his line, 8. A season of chaos, 9. Outburst of violence and riot, ro. Apogee and decay of Turkish power. Characteristics of the Turkish soldiery, rr. The organization of the Janissaries, 12. Turkish administration, 13. Balkan States before 1453 , I4. The rise and reign of intrigue, 15. Efforts at unity in Christendom neutralized by petty jealousies, r6. The Turk in European politics. All Western nations compelled to make treaties with the Porte, I7. Napoleon's seizure of Egypt, I8.

\section{Chapter II}

\section{TURKISH RULE UNDER ABDUL HAMID}

Misconceptions concerning Turkey, 23. Comparative value of travel studies, 24. Some Turkish sketches-a. Personal, $25 ; b$. Official, 28. Claim of Abdul Hamid to be the successor of Mohammed, 29. The Turk as a financier, 30. A customs incident, 3I. The subtle Oriental mind, 32. Misconceptions as to current terms. The subject populations of Turkey, 33. Definite statement needed. The struggle for nationality, 34. Agitation produces restlts of a constructive kind, 35. Mysteries of the situation, 36. The Greek rayahs, 37. A general conviction relative to Greece, 38. Modern Greek, 39. Albania. Slavic uprising, 40. Macedonia, 4I. Turkey in Macedonia, 42. Lines of division in Macedonia, 43. The game of European politics, 44. Abdul Hamid, 45. Aversion of the Shiite Persians, 46. Contradictions noted in regard to true Turkish rule, 48. Balkan conflagration, 49. Primitive conceptions of finance and administration in the Balkan States, $5 \mathbf{I}$.

\section{Chapter III}

\section{THE BALKAN PEOPLES}

(I) Historical survey. The Thracians, 55. The Scythians. The Illyrians, 56. Early immigration. The era of chieftains, 57. Philip II, 58. Coming of the Romans. Interweaving of Greek and Roman influence, 59. Developments in Greece after the battle of Actium. Political instincts of the Greeks, 60. Rome in North Europe, 6r. The Thracians after Trajan's death, 63. Differentiation of the Goths 
on the north shore of the Euxine. The Visigoth migration, 64. The Byzantine emperor Anastasius. The Avar invasion, 65. The Slavs. The Bulgars, 66. Czar Stephen Dushan, 67. The Turks. (2) Racial characteristics: Turk, 68; Slav, Servian, 69; Montenegrin, Bulgarian, 70; Wallach, 73; Albanian, 75; Gypsy and Jew, 79.

\section{Chapter IV}

\section{THE BALKAN NATIONS}

Purpose of chapter. Environment and civilization, 83. The play of politics, 84. Pretext for overthrow of a rude and corrupt despotism, 85. Young Turkey at the helm, 86. The so-called new Turkey. The call of the clan, or racial antagonism, 87. Optimistic Europe, 88. Nicholas of Montenegro. Physical facts and figures, 89. Latest determinations of state-science, 9o. Montenegrin aim and aspiration. Guerilla warfare of Stephen, 9x. Intimacy existing between Danilo Petrowich and Czar Peter the Great, 92. Thirty years of peace, 95. The Montenegrin country and people, 97. Bitter poverty not keenly felt by people of Montenegro, 98. Grecian aims and influences, 99. Ten successive peoples settling portions of Hellas, roo. Greeks in Asia who are fanatical Moslems, ror. Subordination of the Servian Church, I02. The climax of Phanariote rule, I03. Greek uprisings, I04. The blood of the martyrs the seed of the church, I05. Grecian independence, I06. Grecian consolidation, 108. Prince Alfred the choice of the people, 109. Social life in the Balkans, IIO. Features of the public morals, III. Prosperity within the borders of Greece, 112 . Influence of Germany in Greece, $x_{13}$. Motto of King George, I I4.

\section{Chapter V}

\section{THE BALKAN NATIONS}

The Russian idea, II7. Disintegration and decay of Turkey during the Napoleonic epoch, I I8. Birth of Rumania, I I9. Cousa acknowledged as Alexander John I, Sovereign Prince of Rumania, I 20. Nature proves an enemy to his plan of reform, I20. Rumanian origins, I22. Rumania in war, I23. Social and economic organization of Rumania, 125. Bulgarian beginnings, 126. Religious secession, 127. Accession and reign of Alexander, 128. Accession and reign of Ferdinand, 130. Court and people, I3I. Sophia, 132. The rise of Servia, 133. Servian vicissitudes, 135. Reign of Milosh, I36. Revolt led by him, 137. Militant Michael and Alexander. Second reigns of Milosh and Michael, 138. The "Great Servia" idea, I39. Milan IV, r40. Alexander I, I4I. King Peter. General characteristics of Servia, I42. Religion as yet largely superstition, 143. The passion for control a species of imperial insanity, 144 .

\section{Chapter VI}

\section{THE REVOLUTION OF 1908 AND ITS CONSEQUENCES}

Turkish apathy and corruption, 147. Feebleness and futility of the Powers, 148. Balkan conditions: (I) Servia; (2) Montenegro, I49; (3) Bulgaria; (4) Greece, I50. Population and finance. Plight of 
the Powers, 151. Germany and Austria-Hungary, 152. The Young Turk Party, 153. Bulgaria technically a vassal state, 154. Sparks before the fire, 155. Crete votes to unite with Greece, 156. Fanning the flame, 157. Young Turks possessed of the courage of their convictions, I58. Italy adds fuel, I59. What Italy had feared, I60. The situation at Constantinople, I6r. The Balkans ablaze, r62. Progress of the war, 163. The sacrifices of Greece, I64. Success of the Allies, I65. Efforts for peace, I66. Progress of negotiations, 167. Rumania's valuation of herself, I68. Proposition submitted by London ambassadors, I69. Second stage of the war, I70. Indications of exhaustion, I71. Partial and temporary peace, I72. Discord among the Allies, I73. The armistice of Bulair, I74. The question of apportioning surrendered territories, 175. Expenditures of Germany and Russia for military equipment, I76. The panic on the Berlin Exchange, 177. The final terms of settlement, 178. The treaty of Constantinople. The new Albania, 179.

\section{Chapter VII}

\section{THE FORMATION OF THE BALKAN ALLIANCE}

The principle of nationality, I83. Futile efforts toward alliance, I84. The visit of Tricoupis to Belgrade, I85. Twenty years of diplomacy, 186. Balkan jealousy and strife. Turkey prepares the way, I88. The Young Turk movement military in character, 189. The political phenomenon of rgro. Dismay of the Young Turks, r9o. A common suffering unites the Balkans, 192. Arrangement of the Young Turks with Rumania, 193. Rumanian policy, 194. Greece and Bulgaria in concert, 195. Suggestions of full alliance, 196. Greco-Bulgarian treaty, I97. Bulgaria-Servian treaty, 198. Russian influence, 199. Principal industry of Servia, 200. Content of Serbo-Bulgarian treaty, 201. The military conventions. Montenegro joins, 202. Formation of the Balkan alliance, 204.

\section{Chapter VIII}

\section{NATIONAL CHARACTERISTICS IN THE LATEST WAR}

Racial strength and influence, 207. The folly of Pan-Slavism illustrated, 208. Macedonian characteristics, 2 I0. The completed partition of Turkey in Europe, 2II. The plight of Albania and Macedonia, 212. Lawlessness in Macedonia, 214. Conditions in Bosnia and the Herzegovina, 215. Naiveté of the Balkan claim of "Christian," 216. Atrocities of the war, 217. Facts proclaimed to the world, 2I8. Intellectual and moral corruption, 2 I9. Facsimile letters of Greek soldiers published at Sophia, 22I. Indications of the national temper. The secret treaty called a conspiracy, 224 . A disheartening conclusion, 225. Sir Edward Grey's declaration before Parliament, 226. The right to be judged justly, 227. The Powers and the treaty of peace, 228. Questions evaded by the statesmen assembled at London. Bulgaria's mistake, 229. Autonomy for Macedonia, 230. Why Greece opposed autonomy for all Macedonia, 23I. Enter Rumania, 232. The duty of a statesman, 233. Servia and Greece, 234. Difficulty of being just to Greece, 235. The Greek komitadjis, 237. Summary, 238. 
the original design requires, however, certain repetitions which the reader is asked to excuse for the sake of clearness.

It is therefore without apology, but with a full sense of their imperfection and incompleteness, that the author lays the results of his observation and investigation before the public. However the ultimate decision may turn in the Balkans, this book contains most, if not all, that will be generally known for some time. It strives, moreover, to state the political, social, and religious problems of the hour as the Balkan States must face them.

In prophecy it does not indulge because the experiments making in the historical laboratory are absolutely without previous indication or trial, and the elements entering in are difficult beyond measure to test and define. Should, however, the outcome be a second federation of the young Balkan States, including all six, even a temporary federation of some stability, a new epoch of European history will have begun. The fate of Constantinople and the Straits will be in its hands. There will be forced upon western Europe some kind of closer union for protection against a hostile invasion of inferior civilization composed of Slavic stock, Greek Catholicism, and Oriental government. Incidentally, Islam and its system will disappear entirely from Europe, and the Mohammedan peoples in Asia and Africa become the subjects of a bipartite Christendom. Pan-Slavism will be relegated indefinitely to the limbo of other phantasms evoked for dynastic purposes. W. M. S.

Princeton, March 15, 1914. 
I

TURKEY AND EUROPEAN POLITICS 


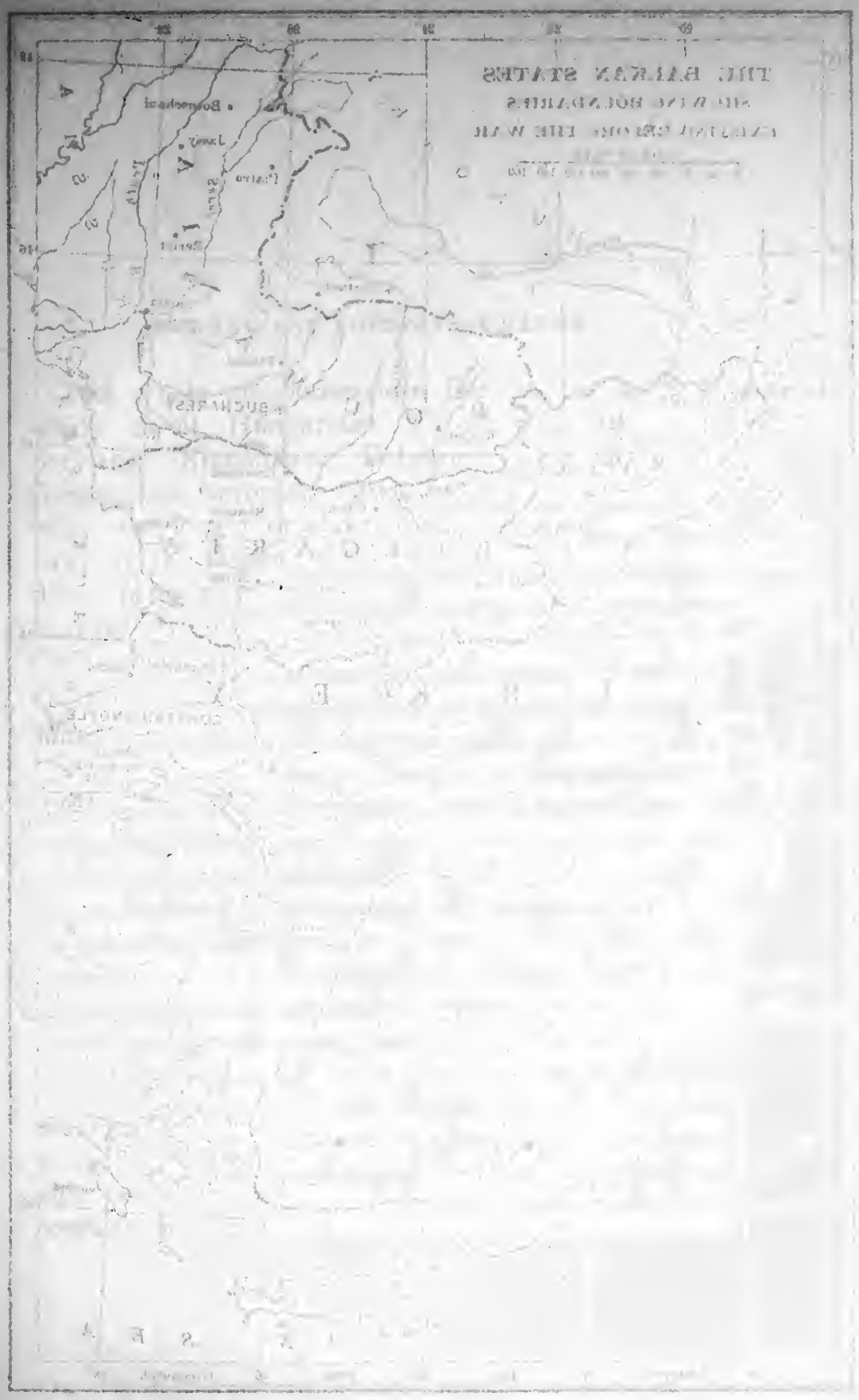




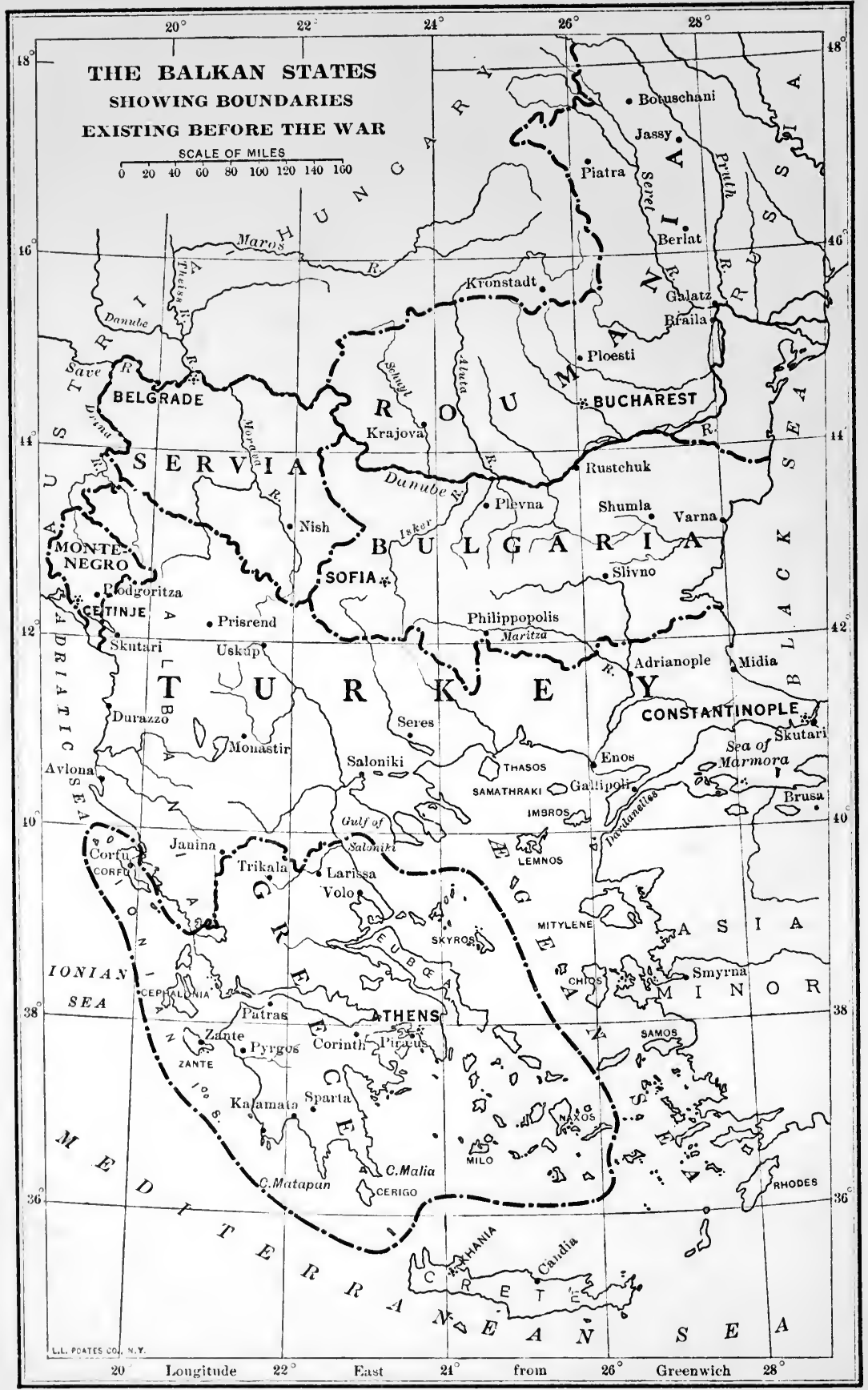




\section{I}

TURKEY AND EUROPEAN POLITICS

THE whole of southeastern Europe, the lands in A Racial which dwell Hungarians, Croatians, Dalmatians, Museum Servians, Rumanians, Bulgarians, Montenegrins, Greeks, and European Turks, has at one time or another, for longer or shorter periods, been under the sway of the Ottoman Turks, and has therefore for those periods been styled, politically, Turkey in Europe. Geographically considered, the territories of these peoples are comprised in the Balkans or the Balkan peninsula, a broad and comprehensive designation, which, though loose, is historically very useful. As time is measured in history these great domains were very recently under an Asiatic despotism and display throughout their extent certain surviving characteristics of its disastrous sway. While the boundaries of Turkey in Europe have steadily been receding to the eastward until now they are under the very walls of Adrianople, yet in the new states which have been established in the Balkans there remain a few Asiatic Turks and many European converts to Islam who are Turkish in sympathy and religious allegiance.

The southeastern portion of Europe is thus an ethnological museum, and what with the neighboring ethnic stocks of Asia Minor a trained observer was able very recently within a few brief hours to distinguish among those who crossed the Galata bridge 
in Constantinople representatives of thirty-eight different so-called nationalities. This word means persons belonging to loose unions of blood-related clans and tribes, which differ from each other in origin, institutions, habits, garb, and to a considerable extent in both religion and language. All these are found in greater or less proportion amid the inhabitants of Constantinople and its suburbs. Such variations mean, of course, successive strata of population and settlement due to conquest, or immigration, or merchandising, or missionary enterprise, or even mere temporary residence for some reason or another. But the Balkan States as a whole are inhabited by the South Slavs with an intermixture of Magyars, Bulgarians, Wallachs, Albanians, and Greeks. An account of their origin and distribution will be given in a following chapter.

Fall of Byzantine Empire

Opinions differ widely about every detail of the decline and fall of the East Roman, or Byzantine, empire. We are not at all certain, except in a very general way, as to the races, at least in their proportionate distribution, which inhabited its European territories, and while we justly characterize its administration as a pure despotism, we know with accuracy nothing about its workings except that, in general, the details correspond to those of Roman administration under Diocletian and Constantine the Great. But we do know that there was a continuous change, a devolution which weakened every activity of the state, deprived it of all offensive strength, and rendered its powers of resistance inefficient. Its disintegration began as early as the eleventh century, when the Seljuke Turks, a Mongolian horde from Central Asia, gained a foothold in Asia Minor, established themselves at Iconium as 
their capital, and began the forcible conversion of the surrounding populations to Mohammedanism. It was I46I, four centuries later, when David, the last socalled "Roman" ruler, yielded Trapezunt to the Osman Turks. Thereafter there was not a trace of "Roman," then synonymous with Greek, power in Asia; the name alone survived in that of the Greek-speaking population, the Romaike, a people already commingled in blood with the numerous Christian Slavs who had settled among them, and destined to become more and more a mixed race, preserving, however, as a bond of union, the cult of the Greek Church and the use of the Greek language.

Under Justinian (527-565) the Roman power extended from Persia to Portugal on all shores of the Mediterranean except where the Franks commanded Turkish Advance the mouth of the Rhone; by the year Iooo, though retaining Italy south of Naples, it was limited on the west by the Adriatic, and on the north by the Danube and the Euxine. Thereafter Turkish invaders in Asia from the eastward and the Latins (Venetians, Lombards, Dutch, and French) from the westward rendered its strength less and less considerable, its existence more and more precarious. It is therefore questionable whether the Turkish advance was an occupation or a conquest. One thing is sure, that when they met their first really vigorous and well-organized Western foe under John Sobieski, less than two hundred and fifty years ago, their advance was checked; the tide of their victories at once began to ebb. Hungary cast off their yoke with little difficulty, in spite of almost internecine civil wars, in I699; Servia followed the example a century later; Greece and Montenegro within the memory of our fathers, and in our own day 
Extent of Turkish Invasion and Rule

Rumania and Bulgaria have secured real independence; to Albania has been promised a high degree of autonomy.

Yet such a bald summary would leave a false impression of Turkish history and requires some illumination. The East Roman emperor regarded himself as in the line of succession from all the Roman emperors, but he spoke Greek and was a fanatical Christian of the Greek rite. He asserted the supremacy of state over church, but was crowned and anointed by the Greek patriarch, was set apart as an Oriental despot, was shut in by a pompous ceremonial and etiquette, and was exhibited as a demigod in gorgeous attire. $\mathrm{He}$ was at all times protected by a mercenary bodyguard and surrounded by sycophants and ingenious flatterers, who exercised such political and military power as by his will survived, to their own advantage and that of influential court favorites. All vestiges of West Roman institutions, such as the Consulate and Senate, were early swept away; even the patriciate was stripped of dignity and power, and the cities were deprived of all their liberties. The number of officeholders was proportionately enormous at the outset and steadily increased to the end. Through these, every single one of whom was directly dependent on the emperor, as he believed-on some courtier as a matter of fact-a feeble, ineffectual, and finally oppressive administration was carried on. The members of this service were divided into several ranks and dignities, each with separate privileges, income, style, garb, and title. Every province had a governor, or statholder, with whom an assessor, or legal official, was associated in the management of the courts. The taxes were farmed, these two chief officials being 
bound to the regular payment of enormous sums to the emperor, whose treasury was alike, with no pretence of distinction, imperial, fiscal, and personal. Besides, there were local taxes of grinding severity, levied without pity. What with perpetual rebellions and foreign wars, what with the terrific expense of maintaining mercenary fleets and armies, what with the lavish provision of games and feasts to propitiate the populace of the capital city or cities, there was no chance for Justinian's great law system to protect anybody or anything. There was some patriotism, much personal courage; there were instances of unselfish devotion, and at intervals were found many men of high personal character to give a certain relief to the dull, sorry level of social, political, and economic debauchery. But between the ruler and the ruled there was an aw ful gulf which neither cared to bridge, such was the sodden inertia of the system.

The incoming Turks were devout Moslems. Victorious, Islam from the outset offered three alternatives to its conquered foes: believe, pay tribute, or die. As the conquerors rolled in resistless flood ever farther and farther toward the west, they killed many; many more, the great majority of the working classes, preserved their Christian faith, found life sweet, and paid. Their tribute was no larger, their treatment no more merciless than before. A certain considerable proportion of the great proprietors and upper classes, hitherto of the Greek confession but without much religion except a ritual, accepted the faith of the conquerors and identified themselves with the new tyranny as they had with the old. The Turks who entered Europe were never very numerous relatively; they were courageous explorers and fighters, and after con- 
quest they substituted themselves for the Byzantine administrators and perpetuated the same oppressive system. Only now, the ruler had a faith which regarded the professing Christian as a dog, a hog, a chattel of the vilest type. The immense Christian population beneath him were thenceforth for centuries designated as the herd, the rayahs. Their treatment by the Turkish rulers was ever more leveling, ever more brutalizing; and the fiber of their Christian character, never morally very tough, was steadily relaxed until the weapons of the weak, deceit and falsehood, practiced almost without interruption, generation after generation, left no place in the spiritual arsenal for manly or Christian virtues, except those of a certain dogged industry and traditional fidelity, largely exercised under the compulsion of selfpreservation.

The earliest, or Seljuke, Turks had confined their warlike activities to Asia and were content to consolidate their power in four different centers under as many lines or families of leaders. They were at the climax of their power about the end of the eleventh century, controlling virtually all of Asia Minor and those parts of Persia where they first appear in historical tradition. There seem to have been at least three migrations of them from their original seats. Still another Turkish stock, small in number but fierce and capable, came into prominence during the following century, the Oghusians. These steadily encroached on the rule of the Seljukes, and finally a certain Ertogrul, son of Soleiman Khan, planted himself and his people firmly in northern Phrygia. It was his son Osman, Othman, or Ottoman, who founded the power and the fame of his line; and the son of Othman, 
Orchan, reduced Bithynia and Moesia to complete subjection. Establishing himself at Broussa as his capital, he crossed the Hellespont, captured Gallipolis on the European shore and made ready to attack the East Romans at the heart of their government. Murad I, his successor, with an army which he organized on a sound and permanent basis, extended the Ottoman dominions to both Caramania in the east and Thracia in the west. He perished in 1389 on the hard-fought field of battle (Kossowo Polje or Amselfeld), where the Servians were utterly routed. So far, the Turkish expansion was, in appearance at least, a real conquest, a series of victories over stubborn foes.

These foes, however, were neither united nor organized, as were the invaders. Seven years later Bajazet I, son of Murad, having overrun both Greece and Wallachia, was summoned to meet a coalition of the Christian powers under Sigismund of Hungary at Nikopolis. There was a desperate battle, and the Turks were victorious, but to no avail; Tamerlane swept in with his Mongols, defeated Bajazet at Angora in 1402 and drove him into an exile, whence he never returned. There were then eleven successive years of chaos before one of his four sons, Mahomet, succeeded in reconstructing Turkish power. Having done so, he kept the peace for eight years of recuperation. Murad II inaugurated another career of conquest and expansion: Thessalonica, Corinth, Patras, and part of Albania fell into his hands. But in the latter country he could not overcome the resistance of Scander Beg, fought indecisive battles with him, and was utterly defeated by Hunyadi, Prince of Transylvania, at Nissa in 1443 . $\mathrm{He}$ conquered at Varna in I444, and again at Kossowa in 1448 , however, leaving a substantial, united force, 
political and military to his son, the great Mahomet II, styled the Conqueror. $\mathrm{He}$ it was who crushed the East Roman empire, captured Constantinople in 1453 and made it the Turkish metropolis, thus establishing Turkey as a European power and opening a new epoch in European history. Six years later he turned Servia into a Turkish province (1459), and in further campaigns reduced to Turkish possession the island of Lesbos (1462), the most of Bosnia (1463), all of the Peloponnesus (1479) and Trapezunt (I46I). Five years later he subdued the stubborn Caramanians (1466) and after another breathing space reduced the Tatars of Crimea to subjection (I475). Still another five years later he landed an army in Italy, captured Otranto, and died in $148 \mathrm{r}$.

His dynasty and his people were sated for a time with conquest. Bajazet II reigned in outward peace for a generation, although the palace cabals, the jealousies of princes, and the rivalry of factions exhibited the inherent weakness of every Oriental despotism, whether Moslem or Christian. It was an outburst of violence and riot in the palace precincts which put his son Selim I on the throne. The scenes enacted were almost identical with those familiar in Byzantine annals, or in Saint Petersburg when Paul was murdered and Alexander I ascended the throne little more than a hundred years ago. The sequel, too, was parallel; the public attention was drawn from home disgrace to foreign conquest. It was Selim who hurled the Persians across the Tigris, abased the proud Mamelukes in the conquest of Syria and Egypt, and transmitted to his successors the title and spiritual supremacy of the Caliphate. Soleiman II ascended the throne in I519, two years later reduced the Hungarian frontier 
fortress of Belgrade, annihilated the Hungarian army at Mohacs, and after another eastern campaign established his power at Ofen, the Hungarian capital, in I529, declaring the kingdom of Hungary to be a vassal state. Here his fortunes began to wane. Dreaming of an advance into Germany, he besieged Vienna, but was driven off. In 1533 he concluded a peace which restored most of Hungary to semi-independence on condition of her paying a moderate tribute. But King Ferdinand of Austria revolted at the price and in I54I war was renewed, the Turk was victorious and Hungary became a Turkish province. Meantime Soleiman had wrested from the Knights of Saint John the island of Rhodes; from Persia Tabris, Van, and Mosool, together with the feudal suzerainty of Georgia. His fleets conquered and reduced to terrified subjection all the Barbary States and many of the Venetian possessions in the Ægean. The Turkish corsairs were feared in Spain and were not unknown on the African shores of the Atlantic; they even penetrated to the Indian Ocean. Soleiman died in 1566 on an expedition against a rebellious Hungarian city and left the Turkish power at its apogee, to begin its decay under the reign of a weakling successor, his son Selim II, and a century thereafter to accelerate the almost unbroken process of its fall.

No one has ever questioned the physical courage of the Turkish soldiery. Since their first appearance in history the Turkish forces, men and officers up to the highest rank, have been brave and resourceful on Characteristics of the Turkish Soldiery the battlefield; in tactics and strategy the case is far different. But to a very high degree, the success of Turkish arms in action was from the outset due to the famous corps of the Janissaries, a body of soldiery 
upon whose system of recruiting and organization that amazing military engine, Napoleon's Guard, appears to have been in a measure founded. The Janissaries were a corps of men separated in childhood from their relatives, trained to habits of discipline and unquestioning obedience, inured to hardship, pampered only in their vanity and pride of place. They had no family ties and no attachments of any sort except to each other; their commanding officers were humored with gratifications of money and rich uniforms; to all ranks was permitted every license which did not weaken their bodies or render effeminate their minds. Almost exclusively they were the sons of Christian captives; in other words, they were not Turks at all, but Greeks or Greek Slavs. The corps was at times, of course, a menace to constituted authority, being conscious of its strength and importance, but generally throughout its history it proved a trustworthy prop to the authority of the despot from whose hand it was fed. Through various vicissitudes it lasted to 1826 . In a broad generalization it may be said that the Turks owed their success as conquerors to the offspring of those who were conquered. The idea of such a corps was not, however, original; the Varangian guard of the Byzantine emperors, though widely different in constitution and organization, was nevertheless a body of struck and selected men, proud in its efficiency, devoted to its officers; and being stationed so far from the Western lands whence it was recruited, it knew no allegiance except to its commanders and their chief, the emperor. What was original in the organization of the Janissaries was the source of supply and the uses to which it was put as a model and stimulus to the whole army. 
The administration of the Ottoman empire, more- Turkish over, was in the main intrusted to men who were neither Turks nor even Moslems. The aristocratic Administraquarter of Constantinople was Phanar, where dwelt the wealthy, refined, and adroit Greeks of the capital. From among these shrewd and wily Phanariotes the Sultans selected their viceroys and administrators for most of the difficult posts. As conquerors (and at the outset) the Turks knew only nations as the units of administration; these nations were encouraged to keep their own organization, because it was much easier for the busy invaders to deal with a few leaders than with the vast horde of natives. To each Patriarch, Vicar, or Grand Rabbi and his advisers, suitable place and station were assigned in the capital, and the source of authority was thus easily accessible. Beneath the farreaching results of the sparse Turkish immigration still lay fallow the fact and the idea of Byzantium: there was the Greek Church in all the ramifications of its ecclesiastical order; and to the Moslem, religion, aside from material interest, was the strongest conceivable bond of nationality, as, indeed, was then and still remains the case with the devout Greek Catholic. This administrative system was a crude novelty, invented and operated because the court religion was not that of the masses, and, further, because there were sectarian divisions among these: three of the Greek Orthodox Church, two of the Armenian Gregorian Church, one each of the Roman Catholics and Jews. When, later, there came into being Reformed Congregations-American, German, English, and Greek-these were nominally regulated according to the same system. In one sense Turkish Islam has been tolerant in the widest extent-from necessity. Without some 
degree of contentment among its Christian subjects there would have been no revenues. But along with religious tolerance there was and is among orthodox Mohammedans a social intolerance of the most offensive sort. The contempt of the Moslem for the Christian is inexpressible. Occidental influences, however, began early to modify Mohammedanism, a religion which itself originated with the intestine schism of Shiites and Sunnites; such sectarian tendencies were speedily developed wherever it was established. The Eastern Roman empire had intimate friendly relations with the Western Caliphate, and vice versa; but with the fall of Constantinople an enormous interaction with Occidental Christendom was inaugurated on the political and social side. For this the Phanariotes furnished not merely men and measures and channels of communication but also favoring influences.

Balkan States Before 1453

The story of the Balkan States of to-day antecedent to 1453 is not in the scientific sense really historical. Their institutions, laws, organization, leaders, all have human interest, but they did not affect in any way the great central current of that history which explains the conditions of to-day-except in one regard: as the memory of Byzantium first stirred the modern Greeks to a revival of patriotism, so that of Czar Simeon's Bulgarian empire in the ninth century was a spur to the Bulgarians in the nineteenth; and that of Stephen Dushan's Servian empire in the fourteenth is the pride of the new Servia. These vague, far-distant historic traditions of the Balkans echo down through the centuries, profoundly stir patriotic emotions, arouse national aspirations and are incentives to action. So far, the story of the Balkans before the 
fifteenth century may be called historic, but that term can be correctly employed only from the date when the Ottoman empire became a European power.

There is no sense of the word in which the successive renascence periods of Western Europe can be called political. Feudalism was a social and economic The Rise and Reign of Intrigue system, the city commonwealths were mercantile concerns; the so-called kingdoms were unrelated aggregations of town and country units with no organic connection; Christianity in the fifteenth century had relapsed into paganism, and paganism of a rather degraded sort at that. The fall of Constantinople, the steady conquering advance of Islam against Christendom, the catastrophe of Rome, profoundly affected Western Europe and recalled the days of Charles Martel. There was burning indignation, and fierce debate and bitter lamentation. But there was no manly resolve followed by virile armament and resolute resistance. On the contrary, the Ottoman successes dazzled and hypnotized the Christian powers. Craft and guile were the weapons of the cringing weak. The Sublime Porte-such was the climax of swollen Oriental phraseology-became the resort and the jousting ring of diplomacy: the kings of Europe, its Popes and doges and emperors, were there represented by their most adroit and habile ministers. The fortunes of the Western world hung on the palace plots, and the successes of reigning favorites in securing the nod or wink of favor from some Moslem Padishah-lord of lords-with the sobriquet of Splendid, or Magnificent, or Conqueror. Our word "Sultan" is not theirs.

The establishment of Venetian, French, and Spanish power in parts of the Byzantine empire had, of course, already drawn the Balkan peninsula somewhat 
into the sphere of Western politics when Constantinople fell into Turkish hands. The further advance of the conquerors accentuated Europeans rivalries; Venice, Spain, and the Holy Roman Empire and the Pope entered into the Holy League of I 495 to check and turn back the oncoming Moslem tide. In vain; Venice was a despotic oligarchy and had no strong and settled policy. Losing Rhodes and the Peloponnesus, it cringed to the Sultan. Maximilian I, distracted by troubles internal and external, laid before the allies at Cambrai in 1517 a plan for the partition of Turkey, but the empire could raise neither soldiers nor funds to pay them, and the Hungarian nobles made terms with the Sultan, while both Austria and Bavaria lay wide open and unprotected against foreign invasion. Francis I, "the most Christian King" of France, with the support of all who feared the empire, concluded the treaty of I 535 with the Porte which made his nation the "most favored," and Venice paid contributions for the further strengthening of the Sultan's forces. Poland, under Sigismund II, and Russia, rising into a congruous and powerful nationality under Ivan the Terrible, were the only doughty foes of the Turks, who now had not only France but England as allies; both were irreconcilable enemies of the Hapsburgs in Spain and Austria. Such petty jealousies neutralized every effort at unity in Christendom, and the Popes, weakened in their spiritual supremacy by their unimportant secular power and their moral laxity as Italian princelets, were helpless to arouse Europe for organized action. Both Gregory $\mathrm{X}$ and Sixtus $\mathrm{V}$ exerted unsuccessful efforts; already the Reformation movement was in full swing and ecclesiasticism was daily more powerless. 


\section{TURKEY AND EUROPEAN POLITICS I7}

Thereafter the Ottoman empire, whether vigorous or feeble, was an integral part of the European statesystem, an element to be reckoned with in maintaining The Turk in European the balance of power; especially after the treaty of Westphalia, which recognized the secular as predominant over the ecclesiastical forces in its unstable equilibrium.

In its largest sense-spiritual, political, and economical-the world movement has in historic times been dependent upon the reciprocity of Orient and Occident in their exchange of relations. With the Porte all western nations, France at their head, were compelled to make treaties regulating religious and commercial affairs. From successive Sultans were secured, not of right but of grace, the concessions under which Latin Christianity could maintain its establishments within their realms, the so-called Capitulations. The diplomatic privileges of extra-territoriality and consular courts to protect resident Europeans of the west from the injurious administration of the Moslem law were likewise granted by the Padishah as favors. The Turkish successes of I 737-39 made diplomacy an interesting game, for Russia had now become for Turkey a waiting, watchful foe; the situation was parallel to that of Greece with Persia, Rome with Carthage and Parthia, medieval Christendom with Arabic Islam. Russia's aims have throughout been clear enough: she desires the key to her own door; claiming as the embodiment of Greek Christianity to be the successor of Byzantium, she wants Constantinople; the admitted incorporation of Slavic power, she wants the hegemony of the Slavic world. This end she has in the main pursued without external help: once she has had Austrian military aid against the Turks, but when a plan 
to divide Turkey in Europe between the two powers was laid before her it was filed away in dusty archives. Between her and her goal lies an obstacle difficult to surmount-two hostile nations: Hungary, the wondrous Magyar state, and Rumania, a rising power claiming to be Latin. By sea she is checked through Great Britain's vigilant guard of her Oriental trade through the Mediterranean.

Napoleon's seizure of Egypt was abhorrent, of course, to Russia, nor could the Sultan accept him as the chosen saviour of waning Turkish power; he seemed greatly to resemble a wolf in sheep's clothing. Thus England and Russia drew together, while the latter began to encourage and support both Servia and Montenegro in order to maintain some influence in the Balkans. She even lent a hand to Greece, and England made common cause; while France stepped into the arena as an abettor. All three were under the compulsion of popular sympathy with the oppressed. In vain and too late, Austria saw the mistake in her policy and was long a helpless observer, until circumstances over which she had little control gave her Bosnia and the Herzegovina. It was a strange spectacle when $\mathrm{Me}-$ hemet Ali of Egypt, asserting a sovereignty on the Nile and in Syria, threatened the existence of Turkey, and the speedy supplanting of a weak by a strong Moslem power at Constantinople. Russia was forced to support her sedulous foe, while both France and England sided with the rebel to secure their Egyptian interests. The Czar obtained in compensation for his help an obligation from the Sultan to close the Dardanelles against Russian foes; thereupon he assumed the protectorate of Greek Christians in Palestine, as France had that of the Latins since the treaty of 
Francis I, and so by religious influence Russian political influence became paramount in the Balkans. The Crimean War released Turkey from her bondage to a certain extent ; French influence gained the ascendency at Constantinople once again. As the second French empire waned, Russia's scheming, never remitted for an instant, secured once more a ground for intervention in behalf of the downtrodden rayahs, and the swift campaigns of Ignatieff with Rumanian aid as a determinative element of success were followed by the attempted dictation of a treaty at San Stefano almost within sight of Constantinople, which would have completely dismembered Turkey's European possessions. The great powers would not tolerate such high-handed procedure; the theatrical statesman then premier of Great Britain, Disraeli, sent a fleet through the Dardanelles and transported Indian troops to the Mediterranean. The Treaty of Berlin followed in I878; made only to be violated, it has since steadily and gradually fallen into desuetude, and the latest events have remitted it to the rummage chamber of antiquated public charters. 

II

TURKISH RULE UNDER ABDUL HAMID 

TURKISH RULE UNDER ABDUL HAMID

WHAT our grandfathers and fathers called Turkey in Europe was governed much as the Turkey in Europe of ten years ago was still governed. It was bounded by Austria, Russia, the Black Sea, the Bosporus, the Sea Misconceptions Concerning Turkey of Marmora, the Dardanelles, the Egean, Ionian, and Adriatic Seas. At that time the study of geography was strangely embryonic and imperfect. School children had spread before them maps upon which there were splashes of vivid color and unflinching lines of black which marked national boundaries. It is no exaggeration to say that the passing generation had in its youth little conception but that the homogeneity of nationality with which they were familiar at home was to be found within the territories represented by each of these dividing lines. If it was England for the English and France for the French and so on, why not Turkey for the Turks? Starting from this deepseated conviction, a few of the better educated and more intelligent read such delightful books of travel in Turkey and the Orient as Byron and Kinglake had rendered attractive and fashionable. Even from the perusal of them, there survived a general impression that within the Ottoman empire there were ruling Turks who were Mohammedans and gentlemen; that the aristocracy was fairly refined and likewise Mohammedan; and that there was otherwise a huge plebeian mob separated in refinement and culture from the rest by an impassable chasm. 
For this and other reasons, there was crass ignorance of the situation among those who twenty years ago constituted the overwhelming majority of Western nations throughout the Western world; Byzantium and the migrations of peoples in Eastern Europe were matters either of the vaguest knowledge or, more commonly, of total ignorance. They were not aware that Turkey in Europe, entire, and Turkey in Asia, in part, were populated by peoples who, whatever they might be, were not Turks at all, having no slightest relation with their masters in blood, religion, institutions, or aspirations. It is a humiliating fact that, even in the highest Western civilization, somehow the man on the street, the person who babbles about anything and everything, really forms that self-styled public opinion with which intelligence is in perpetual warfare. It is but a very short time since that kind of public opinion thought the question of Turkey to be no question at all. Why, of course, the Turks should have Turkey; certainly; what business is it of others to meddle with a man in his own home?

Comparative Value of Travel Studies

There seems to be a general agreement that travel is a highly commendable form both of recreation and study. In this impression there is some truth, but in reality there are only two kinds of observation by intelligent travelers which have real value for intelligent readers. Foreigners who live long in any land and make a careful study of its conditions, of its people, of its institutions and politics, probably produce the literature of travel which has the highest intrinsic value. Nevertheless, long residence among any people, particularly among Orientals, blunts original national character and conviction, diminishes the keenness of observation, and results in a subtle form of assimila- 
tion. Hence therefore the impressions of a mere tourist, wandering leisurely from place to place, coming little in contact with the people, but using his eyes and his judgment with the vigor of the person fresh from home and soon to return thither, have a value all their own, which is possibly quite as high as that in more elaborate studies. For this reason the author ventures to give some account of what, in the capacity of a tourist under the Hamidian regime, he himself saw and heard. Were it possible to give an exact reproduction of the impressions received by one making, as it were, a bound from the heart of the West into the heart of the Hither East, much would be made clear which is certainly even yet very dim to the great mass of educated people, whose only travels are those of the fireside.

If the population of what was two years ago called Turkey in Europe was, as is likely, about six millions, less than a third were Turks; and in those vast regions once under Turkish sway, the lands of Greece, Bosnia, Some Turkish Sketchesa. Personal the Herzegovina, Servia, Bulgaria, and Rumania, there are virtually no Turks at all. They can live only as they find dumb, servile human cattle to herd, drive, and slaughter. They never forget that they came from the upland steppes of Asia; they have always been careful, when possible, to bury their dead across the Bosporus in the soil of Asia. From Asia they came, to Asia they return with little regret; and being a totally unhistoric people, it is doubtful whether centuries of European abode would in their future tradition be much more than a tale of Scheherezade.

Of the primitive folk-stocks the Turk has retained nearly all the virtues, and they are many-so many as to make a normal Turkish gentleman a most agree- 
able and even lovable person. With his womankind uncontaminated by Western notions; with his faith in Islam-a faith not native but acquired and inheritedundisturbed either by Arabic mysticism or Occidental casuistry; with his pride of official rank and garb fully gratified or with scope for his unquestioned and oftproven ability as a soldier, the Turk exhibits many fine qualities. It matters not that his salary as an official is never paid; there is the land of "baksheesh" or bribery always open. It matters not that the shelter which we call his house is bare, rickety or in disrepair; is he not naturally a dweller in booths or tents? It matters not that his towns are filthy and unwholesome, that disease and death stalk abroad; his hour will strike only when fate ordains, as it would anyway. It matters not that there is plenty to-day and want to-morrow; such are the vicissitudes of life. If it rains, we are wet, that is all, but if the sun shines let us enjoy it; when battle is raging let us fight too, so Allah wills, and so on through the long range of human conditions and conduct.

To apprehend a resignation that verges on apathy we must reverse almost every concept we have; in order to understand and do justice to the Turk we need a fourth dimension. $\mathrm{He}$ is our antipodes. But he is domestic, hospitable within his possibilities, companionable, interested in you and in such life as touches his interests; he has a dignity, a repose, a pleasant way which are delightful. Above all, strange as it may sound at first, he can be, for reasons of expediency, the most tolerant of all human beings. There are in Turkey more faiths, sects, denominations, and religions, more license in profession and behavior, than in any other territorial expanse of equal size. If only the 
adherents of these various cults pay, often and enough, and if only they do not in act, word, or precept subvert existing rule and order, nothing else matters at all. Islam is the most democratic of all natural religions; there are no orders, no priestly intermediation, no governors, no hierarchy of any sort. The naturally independent temper of the Turk is thus confirmed by his faith. There is the caliph, the Padishah, the embodiment of theocratic power; and then there are all the rest, exalted or humbled, enriched or impoverished, preserved or destroyed, kept alive or killed, regulated in every relation of life by a power and conditions that affect all alike; birth, inheritance, fealty, no such mere accident counts in life at all.

Tolerant and democratic-both, in a contemptuous sort of way-the Turk is also in ordinary life a kindly, gentle soul. His women-folk are under no compulsion or discipline, he is generous to the very utmost; his slaves are scarcely aware of their bondage, so easy is the yoke. With divorce dependent upon his whim and accomplished by his own unfettered will, provided he can repay the wife's dowry, the rearrangement of domestic relations is so easy that social conditions are scarcely disturbed. A disordered mind makes its unhappy owner a public charge; beggars are humored, tolerated, and supported by alms, especially the halt, the maimed, and the blind; before their banishment, the dogs of Constantinople drove ladies from the sidewalks and made vehicles swerve by their sluggish inertia. Easy indifference and a liberal soul combine to make Turkish life a thing apart; a sort of genial inefficiency permeates it all. Yet beneath it is the volcano of indiscipline. Guile and the oiled feather first; then, if thwarted, fury and recklessness. Smooth 
promises with perpetual delay; then performance under compulsion with the Parthian arrows of atrocious bloodshed.

b. Official

Some such characterization, however imperfect, is essential to any grasp of the first principles of Turkish rule. In the apogee of its extent and greatness, those who immigrated and seated themselves as the mighty were, as was explained, in a minority, much as were the conquering Teutons in the western provinces of the Roman empire. In the exercise of a fanaticism, both physical and spiritual, they simply took what they found. The people on the soil were reduced to a dead level of peasant boorishness; the ruling class stripped land and people of all they dared to take without destroying the wellspring of supply. The arbitrary childishness of Turkish behavior to-day is probably a fair sample of what it always has been. After years of contact with Western ways they have, to be sure, acquired something of European shiftiness and duplicity, but it has served to strengthen their own naif rascality. My dragoman tells the customs inspector not to tumble the contents of my trunk; the police inspector discreetly turns his eye another way; the trunk is closed, and in a few moments the official comes trotting to receive his "gift," which he divides with him of the blind eye.

This is the whole system in miniature: the feint of honesty, the practice of roguery, a pretense of knowledge, the crassest ignorance in fact. The Ottoman empire has army, navy, police, treasury, foreign office, and all the paraphernalia of administration, internal and external. From beginning to end the whole machinery is an empty form, a mill that grinds no grist; and the palace clique or camarilla or kitchen cabinet, or 
a so-called "committee" of malcontents, or a harem intrigue, or the Sultan's wish determines the course of all affairs. A parliament met once under Abdul Hamid, was adjourned, and for the ensuing thirty years never met again until the latest revolution established or claimed to establish the semblance of another legislature. There is once again a paper constitution and a constitutional monarch-in name, as is all the rest. Warships float, but their inefficiency is notorious and ridiculous. When the United States grew restless in the demand for an indemnity due for the destruction of American property, a cruiser was ordered from an American shipyard; it arrived and anchored in the Golden Horn, where it ended its efficiency in peace; the published price contented the Turks and seemed, somehow, to cover the indemnity to us.

As is well known, Abdul Hamid, probably the last real Moslem Sultan, caliph, or Padishah, as he was styled, rarely left the inclosure of his royal borough, known as the Yildiz Kiosk. Within its carefully guarded, spacious inclosures, in its palaces and gardens he abode. Thence he reigned and ruled; and, claiming to be the successor of Mohammed, he performed public worship at the ceremony of the selamlik in a pompous procession and recession to and from the near-by mosque which he built for the purpose. Impressive as a spectacle, the selamlik was also impressive as a historic act, for in it Abdul Hamid appealed to the millions and millions of Islam as perpetuating its power and its system. He had not a single attribute which entitled him to arrogate the headship of Islam to himself, and millions of the faithful refused their fealty. But many millions more passively accepted his lordship and admitted the sanctity of decrees issued 
by his religious vice-regent, the sheik-ul-Islam. It was therefore an awful thing when a miscreant found his way into the very heart of Yildiz Kiosk and, during the selamlik, flung a bomb, the dastardly weapon of anarchy. But the thing did happen, and the momentous question arose as to how dynamite had been smuggled into the empire. What actually occurred sounds like a joke; but with a few other examples it may serve, being a fact, to illustrate what manner of men then ruled at Constantinople.

For years a British merchant had been importing and selling fireproof safes. A new consignment was in a ship just arriving. He was summoned to the customs stores to "open" them, for a wily official had guessed and suggested that the dreadful explosive had been concealed in these safes, and that more might be found in the newer ones. The owner appeared, glad to comply, and threw open wide the doors. The matter was not so simple; "opening" meant displaying the packing between the steel walls; and so with sledge and chisel the whole consignment was destroyed, and there was no redress. The familiar finance where the lender gives fifty, and the poor, eager borrower writes a hundred in the bond was long employed by the great usurers of the West when Turkey wanted a loan. Neither principal nor interest being paid, a result foreseen by the original parties, the various countries of Europe intervened in Turkish finance to "readjust" the debt for the creditors, a class of unsuspecting investors upon whom the obligations had been unloaded by the negotiators. So there exists in Constantinople a board of highly paid gentlemen, all but one from the West, who take a certain proportion of the customs into their own hands for paying interest and refunding principal. 
Compared with those in our own American Utopia, the customs dues in Turkey are (or rather were) trifling, averaging about eleven per cent. To the Porte, looking abroad at the triumphs of protection elsewhere, it seemed desirable to fill the official purses by raising the tariff an average of three per cent more. There was a mighty deliberation in all the state departments of the Occident. At last the measure was permitted, since the coffers of the commission in charge of the public debt would also profit thereby.

But many, many papers must first be signed in the ends of the earth before the law promulgated by the Sultan could be operative. The ambassadors of the Western powers deliberated day by day on the administrative measures. Meantime the Sultan received an invoice for glassware purchased in France, and to be used at Yildiz. No duty, of course, was to be paid on that. A high official, chief of the secret police, was sent to enter it. His mission was promptly and successfully discharged, but not merely his original mission; the great man, finding at the receipt of custom a large amount of money which the collector had received in the regular way for dues, carried off not only the imported service of glassware, which was his master's, but the money, too, which was also, as he considered, his master's and was, moreover, greatly needed at Yildiz.

The news of this characteristic behavior swiftly reached the meeting-place of the ambassadors; and the British representative, who was the latest signatory of the new tariff, hastened to the wharf and, finding the news true, at once withdrew the precious signmanual which gave Great Britain's consent. Consternation seized the high officers of his Ottoman majesty: 
why such supercilious behavior, such needless fuss about details? But they yielded, and the vital negotiation was at last concluded, with administrative arrangements to preclude the repetition of such naif proceedings by the Turks in Turkey. Why multiply instances? A professor entering Turkey from Greece has his Persian powder confiscated as an explosive; a trading firm sending into Asia Minor for eggs is suddenly confronted with total loss because, while the permit for eggs is correct, that for wood, the material of the cases, is not. And so on and so on.

It is vital that the degrees granted by the American school of medicine at Beirut should have official sanction. No trouble whatever to get the imperial decree; but the members of the commission were Turks of rank, and as such might not easily pass from place to place. Every year it was a matter of complicated negotiation by the American ambassador to secure for these officials the right to proceed on the business for which they have been duly and legally designated by their august and all-powerful master. It is very hard to believe that the machinery of Oriental government is as simple on the surface or as intricate in its workings as it appears, merely by reason of incapacity. The subtle Oriental mind secures some advantage in its efforts, or apparent efforts, to apply worn-out schemes to new conditions. At any rate, Turkish rule has survived expectation by half a century, and it is its very absurdity, with the aid of a more or less perfidious rivalry among the great powers of the West, which seems likely to perpetuate it indefinitely at Constantinople and in Asia Minor.

Comprehension of the Oriental question by western peoples is further impeded by their total failure to 
grasp the meaning of current terms, in particular the terms "nation" and "Christian," as employed in the Balkan peninsula and in Asia Minor. There are large numbers of Europeans in both: some, as we have mentioned, are there for religious purposes, as missionaries, others for purely secular reasons, chiefly commercial. While there seems no real hostility whatever between these two European groups, yet they see things from a different point of view and have widely varying opinions about many matters. The latter class, with no exception, as far as known to me and several other travelers whom I have consulted, considers the ruling Turk vastly superior to the so-called Christian peoples over whom he rules. Appearances are that way. In general, like all tyrants, whether patriarchal, theocratic, or merely personal, he is more human than those whom he oppresses. His victims must have time for recuperation before regeneration comes. We need not go far for a parallel. The Ashkenazi Jew, so called, whether he be really an Israelite or not, which is doubtful, when first emancipated from the horrid cruelties inflicted on his race in central Europe for centuries, continues, sometimes for a generation or two, the unpleasant practices by which he mitigated his bondage; but he finally becomes as little of a presuming parvenu as men of other blood, and as often exhibits the highest virtues of social life. This example is all around us.

The subject populations of Turkey were still styled rayahs; age after age they had been held in bondage, sometimes easy, generally most oppressive. Bond slaves find the practice of noble qualities extremely difficult. Most rayahs kept the faith of their fathers, many followed the example of their wealthier kin and
Misconception as to Current Terms 
sought, as elsewhere told, to mitigate their hard lot by professing Islam. In all the provinces once or still under the Sultan there are some Mohammedans, and in a few there are many, who have not a drop of Turkish or Arabian blood in their veins, being pure Aryans, or Japhetites, or Javanes, or whatever adjective best describes them. In the Herzegovina and Bosnia together they number about half a million. Though most carefully and considerately treated, they demand that their religious head shall be appointed from Constantinople, thus refusing incorporation in the Austrian system. The Mohammedans of Asiatic stock, Turks or Arabs, have mostly returned to the land whence their fathers came. The question of superiority can therefore be answered only by comparing those who were once rayahs, but are now independent self-rulers, with those who still rule in unemancipated lands, rulers

Definite Statement Needed

The Struggle with rulers. Of the result in the case of Bulgaria and Rumania there cannot be a question. Bosnia and the Herzegovina are under Austria's iron hand; Servia, though longer practiced in liberty, inherited peculiar conditions and horrified the world by the savage outburst of her unbridled wrath against a faithless king. The European peoples once subject to Turkey are therefore not of necessity Christian either by profession or practice, however widely they differ in many respects from the Turks. Moreover, they designate themselves as nations, using that word in a sense of their own-a sense similar to that in which it was used in central Europe during the middle ages. "Nationalities" would be a better expression.

for Nationality ica is New Europe. In whatever respects that may be true, in one there is an antipodal contrast. We are 
busy making, out of many widely different elements, a great nation, unilingual and homogeneous. Europe, having passed that way in the unification of France, Germany, and Italy, is now returning on its footsteps, and the passion for little nationalities is exhibited on every side. We are all familiar with the Irish question; we note with wondering interest the revived study of the Celtic tongue in Great Britain and the emphasis on institutions of another age. In Belgium the Flemish stock struggles for its language as never before. In Provence the revival of Provencal literature, so long cherished, is now followed by a blind struggle against total assimilation and by a demand for a measure of local independence in the interest of local industry. Throughout the Austro-Hungarian monarchy every one of the eighteen or more petty nationalities is asserting its right to live for and rule itself. The question of Sicily gives the house of Savoy at Rome much to consider, and separatism in the German empire furnishes themes for its journalists. Everywhere on the continent of Europe it is the same story, while simultaneously there is a growing nationalist agitation both in Egypt and India. This is the movement which brought Rumania, Bulgaria, and Servia into a more or less independent life; it is the movement which was long surging throughout Turkey in Europe and created the burning question in Macedonia, whence came, as of old, the bitter cry, "Come over and help us." This in a high degree was the cause of the war.

There is no use in describing the whole stir and struggle for nationality as senseless, a common designation which perfectly describes it to many minds. It is not senseless; the agitation is real, has produced vital results of a constructive kind, and in our day under- 
lay outbreaks of bloodshed and horrid cruelty in lands that are fair, among people who are innocent, capable, and urged onward by noble instincts. The dispersion of peoples, each with its own language, is represented in the scriptural account as a curse laid on men for high treason against Almighty God. Europe is doing its utmost to perpetuate the curse and make it lie heavy on millions of innocent men. Were science and its votaries modest, did theories affect the academic world solely, small harm would be done by self-appointed teachers. But ill-considered, unproven doctrines, by dint of iteration, are made to succeed each other as accepted rules of human conduct. Among many others the theoretical reconstruction of the Aryans, of the Turanians and of the various subdivisions of the same, has been distorted from a useful hypothesis into a maxim of moral guidance. Out of it have sprung the baneful all-Slav, all-German, allanything movements-devices one and all of dynastic land-grabbers eager to use an unselfish and romantic sentiment for their selfish ends. No man knows at this hour what is a Greco-Roman, a Celt, a Teuton, or a Slav. The philologists know the languages and language groups, but no man of standing has ever dared assert that the use of a language proves the blood in the veins of its user.

The movements of peoples, the origin of races, the transitions from type to type or the persistence of type-all these are mysteries. But men behave as if they were as concrete and usable as the multiplication table. In Western Europe there were types so strongly developed that at least there was some excuse for the common error. But when the doctrine spread eastward into less educated societies, it began to work and 
is working havoc with the gains of civilization. To use among such men and women phrases which contain the words "nation," "people," "patriotism," "history," etc., is to sow the whirlwind. When we read that the Rumanians are Latins; that the Bulgarians and the Servians are Slavs of different nationality; that Macedonians are Bulgarians or Servians, according to the opinion of this or that writer, or that they are Greek, as Greece contends, we get the common coin of diplomatic exchange; but it is spurious and counterfeit if passed as historical truth.

There was little interest as to the nationalities of the rayahs while Turkish rule was strong. They were The Greek Rayahs nearly all Christians of the Byzantine type, those in Europe at least, and were hence regarded as one people; for Oriental theocracy cannot conceive of nationality apart from religion. They themselves knew the differences in their origins and in such traditions as they had: some were Slavs, some Vlachs, and some Albanians; some had the blood of Trajan's legionaries in their veins, whatever that was. But they felt more deeply than they thought; the hardships of their common lot and the common worship of their church gave them a stronger sense of unity than of disunity; they were all non-Moslems, all rayahs, and in a sense all Greeks. Moreover, as explained in another connection, among the most useful servants of the Sultans were the old Greek Byzantine families who lived at Constantinople in the quarter of Phanar. These Phanariotes were invaluable as administrators and diplomats; resourceful, guileful, smooth, elegant, refined; and for their precious services they received great rewards. They were the Greeks par excellence; and, running to and fro within the empire, to and fro without, 
they impressed upon all that if there were a second race destined to restore the empire of Grecian Rome, they, their co-religionists, those who spoke their tongue, were the coming people.

Hence, within the memory of men still living it was the general conviction that a greater Greece would one day hold all Turkey in Europe, and that the light of Greek civilization, rekindled in Attica and on the Peloponnesus, would shoot northward to enlist the whole Greek Church within Turkish boundaries in the "great idea," to wit, the restoration of Byzantium in new and regenerate form. This, though it is now stoutly denied, is still the "great idea" of that portion of Turkey first to be emancipated, namely, the present kingdom of Greece, whose inhabitants speak a renovated Greek or Romaic, live on the ideals of ancient Greece, and have with set purpose forgotten the Albanian, Slavic, or other blood that flows in their veins. Coming from the West, travelers differ widely about the advance of modern Greece in Western civilization; but one familiar with the Orient, and coming to Greece from that quarter, realizes the enormous progress which the little population of about three millions has made in unifying, elevating, and purifying itself for the task it has set itself. So recently as the year before last (1912) it might have been truly asserted that the Greek government had made nothing but tactical mistakes, and that Greece had gathered no fruit from her national regeneration. But she bided her time, and the agitations among the Christian populations still left to Turkey in Europe were attributed in large measure, and in all likelihood correctly, to supplies of Greek men and money.

What and who are these modern Greeks? The ques- 
tion will be answered at greater length in another place. Modern For the present a paragraph must suffice. The most Greeks skeptical investigators admit that in most of them is some blood transmitted from ancient Greece, and that there is a proportion of Greek descent in Greece about equal to that of Anglo-Saxon descent in America. For the rest the modern Greeks are either Albanian or Slav or Vlach. Besides the Greeks in Greece there are other Greeks who far outnumber them. They are found on all the coasts of the Ottoman empire; Crete and the other islands, until very lately under Turkish sovereignty, have no other inhabitants important in numbers; they are numerous in Asia Minor, in Syria, and in Egypt. That they have a national type and a national character is undoubted, and they themselves estimate their numbers at twelve millions. This is at best an approximation and, as will be explained later, something of an exaggeration. For the most part these Greeks are faithful adherents of the Greek Catholic Church. While domiciled elsewhere, they remain passionate in devotion to the Greece they style Hellas, the modern kingdom whose people are called Hellenes; and, being masters of commerce and finance, many of them have gained enormous fortunes, from which they pour great sums into Athens particularly, but into Greece generally, for public buildings and endowments. To the outer barbarians who later deluged it, the East Roman empire, Greek as it was in speech and character, was known as Rome or Rom or Rum. The language spoken there has never ceased to be spoken. After eighteen hundred years of devolution or evolution, according to the point of view, it is still spoken by these millions, and, for the reason just given, it is by them called Romaic, to distinguish it from the 
Hellenic, which means either pure old Greek, or the modern written language of educated Greeks in Greece, a language really renovated and cultivated by enrichment from classical Greek. In this remodeling, modern Greek resembles modern Norwegian. The passion for nationality, equally strong in the extreme northwest and southeast of Europe, has in both had recourse to the same means for securing apartness and distinction.

Albania

Slavic

Uprising

At first sight it seems very curious that the national costume of modern Greece was adopted or adapted from that of a stock not Greek at all, a little folk the most remarkable of the European continent, namely, the Albanians, a people, as far as we know, absolutely without any close, or at least calculable, affinity with any other, whether of race, speech, or institutions; still using the oldest known European language; retaining, without unity of religion, habitat or manners, a unity of nature, appearance, and character which sets them absolutely apart from the surrounding populations, with whom they mingle freely but do not coalesce. The explanation is that in a high sense they are the makers of modern Greece.

But if modern Greece owes much to the Albanians, it seems as if her ambition were quenched, her destiny thwarted, by the rejuvenescence of another folk-stock which is not even approximately indigenous, but within historic times has come from afar. It is called Slavic because it uses a Slavic tongue, a language which the immigrant nomads brought with them and gradually forced upon populations which had known Roman culture. These populations were in a measure Aryan, that is, related in speech and structure to other Europeans, but with them was intermingled generously a middle Asiatic race called Bulgars. These elements 
gradually melted into one stem, which now comprises Servians, Illyrians, Croatians, Bosnians, Herzegovinians, Montenegrins, Macedonians, and Bulgarians. The two districts of Moldavia and Wallachia, which form the present kingdom of Rumania, were not entirely engulfed by the wandering hordes of Slavs; at least they retained the form of a Romance language, and in many districts they kept their Roman-Moesian blood fairly pure. Surrounded on all sides by Slavspeaking peoples, they have not escaped Slavic influences in vocabulary and social qualities, but they are as pure a race as any other not a recently mixed one, as are Turks, English, Americans, and their own Bulgarian neighbors.

Hence all the woes and sorrow and cruelty in Mace- Macedonia donia. This situation has indefinitely postponed the restoration of New Byzantium, the erection of a Greek imperial structure with its administrative center on the Bosporus. Its immediate result, however, was and is the heartbreaking situation of the people who dwell in the vales on the southern slopes of the Rhodope Mountains. The population of Macedonia is even more heterogeneous than that of the lands east or west. Here are all the Slavic stocks, or, rather, here is the collective stock, for the lines of division are most uncertain, some Macedonians tending toward Greece, some toward Servia, some toward Bulgaria. Moreover, though their language is sufficiently unitary, yet agitators and propagandists note the slightest local differences as a basis for determining whether the communities be Serb or Bulgar or possibly Greek, for in some of the communes a Romaic vocabulary beclouds the origin of the stock. The individuals thus differentiated, as we explain in the sequel, are not very 
firmly anchored in what they call their nationalities: a Bulgar of the exarchate, for example, who finds difficulty to-day in understanding the neighboring Serb of the patriarchate, may for an adequate consideration be Serb or Greek to-morrow. The situation may at any moment be reversed by a change of conditions, and the change is sometimes kaleidoscopic.

Turkey in

Macedonia

The Sublime Porte again and again promised such reform in the administration of Macedonia as would secure stability and peace. It promised anything the powers demanded as often as they demanded. Why not? There was no intention of performance, and there would not be the slightest possibility of performance, even if there were the best possible will. Besides the Slavs, Servian or Bulgarian, the Greeks and the Albanians, there is a great contingent of Vlachs, some in Epirus, some in Thessaly, many in Macedonia. These mysterious people claim to be Rumanians; they speak a Rumanian dialect, strongly impregnated, however, with words and constructions taken from contiguous peoples. They are industrious and thrifty, but they are scheming, and are regarded with anxious suspicion by their neighbors. On the questions which so agitate the world around them, their attitude is enigmatical; but, like all the rest, they are far from resigned and obedient to Turkish rule in any degree. In the main, they, like the Albanians, lean toward the Greeks, although, again as in Albania, there is a minority party otherwise disposed. Although widely different in habits, some of them living in villages while many are nomadic herdsmen, there is no question as to their essential unity.

This distracted country, therefore, is almost an anthropological museum; only, the specimens are shown 
in a chaotic mechanical mixture, not in orderly arrangement. Encouraged by the example of the three Danubian kingdoms, and especially by the experience of that anomalous portion of Bulgaria known as Rumelia, which fell off from Turkey with no battles except those of words, the natives of Macedonia long for deliverance, for entrance into the promised land of self-administration. Over the former borders there were Servia, Bulgaria, and Greece: all beckoning, all lusting for increase of territory, wealth, and population. Of the three, Bulgaria had in Abdul Hamid's time the advantage. It began to woo soonest; its language has certain suffixes like those used in Macedonia; it has a church using Slavic in its services and taking no minutest direction from the Turkish capital; and, above all, it had, in the year I9IO, an army believed to be of high morale, thoroughly equipped and drilled, quite ready for a coup like that which made Rumelia Bulgarian.

On the other hand, Greece had the money, and those who know Macedonia best have asserted that most of the agitation is due to unscrupulous bands that are half bandit, set on foot and supported by Greek cash. Servia kept her movement of agitation going, but her home affairs were a serious detriment to her ambitions. Three years ago the ablest Servian writer was contending that there are in Macedonia lines of division, racial, territorial and linguistic, and that the rivals should end their rivalry by a tripartite division, each taking its own. Meantime Turkey, under the wily Abdul Hamid, the one most accomplished opportunist in politics, had really nothing to do except to foment race hatred and division between Christians, continuing as of yore to collect heavy taxes where resistance 
was either spasmodic, unorganized, or thwarted by the internal dissension of the communes. There was cruelty and bloodshed and anarchy; the nominal administration probably abetted it all, certainly did not stop it; but the prime movers were the agitators, either native or imported. As was said before, Turkey could not keep a single promise of reform if she would, and would not if she could. Divide et impera. The Servian bands, the Bulgarian bands, the Greek bands entered Macedonia and worked their will on the natives and on each other; the Turk still collected his taxes, and possibly all the more easily because of the unrest and recurrent anarchy.

Abdul Hamid appeared to understand fairly well the game of European politics. Such extraordinary performances as take place within the Austro-Hungarian empire could not escape his notice. German against Slav and Magyar, Magyar against Slav and German and Rumanian, dire dissensions, even among the Slavs themselves, all in the sacred name of church, or nation, or language, or race, or whatever it may be-such a mess of centrifugal forces apparently does not make an Austria-Hungary very strong for external affairs. Yet the destiny of the "eastern realm," which is what Oesterreich means, is, in the minds of many both without and within it, down the Danube. Russia is never idle in the use of Pan-Slavism for her purposes, and by far the largest number of inhabitants in the Danube valley are Slavs. There was and probably still is a Slavic society, claiming an immense membership, of which the president is a Roman (not Greek) Catholic Russian general, continuously wooing these populations in Russia's interest. Its agents fulminated for years in books and papers against the sorrow ful effects 
of the "sauerkraut and sausage" civilization forced by Austria on the long-suffering Herzegovinians and Bosnians. Then there were the three quasi-independent kingdoms, which heartily detested one another. but finally did federate against Turkey and might even do so once more against either Austro-Hungarian or Russian predominance in the Danube valley and their peninsula generally.

These were the nearer cares of Sultan Abdul Hamid, but he prided himself on his intimate acquaintance with the international jealousies of the powers further west, being firmly convinced that the very existence of Turkey in Europe, since 1877, was due to his tact and nice discrimination. He was keenly aware of what public opinion in the West could accomplish, and of how it was formed. But he was also convinced that, constitutional government being everywhere a name and a form, the true Turk is less of a hypocrite in his absolutism than the head of any monarchical democracy.

Abdul Hamid himself was a contradiction, utterly Abdul Hamid inconsistent and incomprehensible to the Western mind, and likewise, as far as our information goes, to the Oriental mind. On the one hand, his interest appeared to be mainly European, and he made on occasion a great show of the very slender Western culture which he possessed. He mustered all his charm for those who represented the West, made desired concessions with the most graceful manner, appointed the friends of his friends to pleasant and lucrative positions in the Ottoman service, emphasized the position of his empire as a European state, and carefully attended to the question of alliances. After having been, as was his father, almost under the tutelage of Great 
Britain and her remarkable ambassador Lord Stratford de Redclyffe, he then turned and vented his bitterness upon that power when Egypt was occupied: finally he concluded that Germany and the German emperor were most likely to perpetuate his sway, at least for a few years, over what was left of European Turkey.

Yet, for perfect play in such a game, much is needed which either willfully or ignorantly he left undone and did not attempt. His real life was in the other and true side of his character. Privately he was most attentive to the Moslem traditions and to the practice of polygamy; and the seat of Turkish power was under his tarboosh, not in the divan of his ministers nor in the great administrative departments, whose palaces form a feature of the capital city. In the palace and almost to the exclusion of the anxious patriot proud of Turkey's past, eager for her well-being and desirous to reform a rotten administration, there appeared from time to time the willful, impatient, crafty, timid tyrant of Oriental tradition. Mewed up for all the days of the year, except perhaps half a dozen, behind the inclosures of Yildiz, he made all his public appearances in connection with the faith and practice of Islam. Though his ultimate fate seemed to depend on the Occident, his prestige, as he well knew, depended on the Orient. He had not a single claim to be caliph, being neither Arab nor lineally descended from the Prophet nor chosen by the Mohammedan world; yet by dint of assumption and agitation he was so recognized by a majority of the orthodox.

The Shiite Persians, of course, loathe the Sunnite orthodox, whether the Sultan be caliph or no, because they prevented the just succession of Ali, the Prophet's son, in the Caliphate; but the agents of the usurping 
Turk were found everywhere else throughout the Moslem world working in the interest of Pan-Islamism, with the Sultan as caliph and recognized head. In India, Central Asia, and China, in Java and in Africa, even in southern Russia, they moved the faithful to enthusiasm for the Sultan as the successor of Mohammed. This was his anchor to windward, and it gave him a strong mooring. It was not forgotten by him that both Great Britain and France have innumerable subjects, fanatic Mohammedans, who would see in violence, or even in a slight to the Sultan, a sacrilegious act against their cherished faith. It was for this reason that the weekly prayer which Abdul Hamid made in his own modest, personal mosque of Yildiz was the occasion of a ceremony, alike military and religious, devised and performed to impress the whole world of Islam. In this half hour's performance he was not the exquisite European who had traveled, who knows men and lands, who identifies himself with the general welfare of Europe and the West; he was the theocratic ruler over the fate and fortunes of millions upon millions of the world's elect, who alone have life, light, and immortality, who are sure of a world to come which dwarfs to vanishing the world that is.

It is trite to observe that no man can be double, no man can be the inscrutable Asiatic despot and the genial constitutional ruler of the West; yet during the selamlik, surrounded by a living wall of choice troops thousands in number, Abdul Hamid made his effort at the former role. As his fine equipage dashed past the visiting tourist who had secured admission to the inclosure by the kindness of the ambassador, there was seen, sitting on the front seat, facing his Sultan, the highest official of the empire. In the place of honor 
was a man of purest Turkish type, with curtained and mystical eye, prominent nose, and a full mouth, with hair and moustaches dyed a blue-black, with square shoulders that felt the weight of care, suspicion, and craft, but bore it doggedly-a man who claimed from the nations, peoples, and tribes of the empire the obedience due to an absolute master, from all Mohammedans wherever found the reverence due to the representative of the Prophet. The onlooker got but a glimpse, of course, but it was a most impressive moment. In the devotion of approach to the throne of Allah, the Padishah sat impassive while the imperial coachmen urged the splendid steeds; when he emerged from the house of prayer he took the reins in his own imperial hands, while his well-trained horses whirled him and his two attendants back to the palace and the harem.

This was the last of the contradictions noted in regard to true Turkish rule. Viewed logically in the light of homely common sense, the maintenance of such a system was utterly preposterous. When it is realized that Christians, of churches both orthodox and schismatic, are oppressed by unbelievers, that the holiest spots of Christian ground are in the keeping of infidels, that savagery and barbarism were fostered and perpetuated, and hideous cruelties practiced throughout this empire, that day and night the cries of the innocent, outraged and brutally murdered, ascended to heaven from lands otherwise beautiful and prosperous, and that all this was going on under and by virtue of European guarantees-no wonder that earnest men and women throughout Christendom assailed the ears of their rulers and cried in despair, "How long, how long?" This, however, is the obverse of the shield; the 
reverse is quite different. Whatever was the case a few years since-and no one now doubts that Turkish soldiers were then the criminal brutes-in the latest years of Hamidian rule everything was changed; the brigands who rendered Macedonia a hell on earth, were outlaws, supported and instigated by the selfstyled "patriots" of one or other of the three bordering Balkan States, while, under pressure from the European concert, Turkish troops make some outward show of repressing the disorder. Time and the chapter of accidents were the last resource of European statesmen regarding Turkey in Europe. It long seemed vital to peace and the balance of power elsewhere that the realm of the Sultan should be kept intact.

But European diplomacy suddenly saw a new and alarming vision, the great light of a general Balkan Balkan conflagration. Less than two years ago it would have seemed preposterous that four Balkan States should be permitted to wage open war for the possession or partition of Macedonia, that the area of desolation and oppression would thus be indefinitely extended in time and space. Yet their recent clandestine confederation and the ensuing war has had no other end or aim.

The atrocities of Macedonia, it must not be forgotten, were mainly the work of Christians. They were determined to force either European intervention or a Balkan war, and in the latter desperate adventure they were successful. In the summer of 1907 the Porte declared officially, and probably truthfully, that it knew of a hundred Greek bands, each numbering thirty and upward, financed by an Athens committee and commanded by Greek officers in disguise. The Serbs brought similar charges against Bulgaria, and vice versa, with Greece reiterating like indictments against 
both. Europe was willing to risk neither horn of the dilemma. The foremost interests of the West in the Hither East were commercial and missionary. Both were jeopardized by the possibility of any other rule over Turkish lands than the misrule which existed. The Slavic ideas of nationality do not include missions, either Roman or Protestant. Under the Hamidian regime these missions had a certain standing and protection. And no sooner has a new state been organized in the Balkans than the commercial door, open under Turkish control, was closed in the face of all the great trading nations, to be opened only on the basis of preference in some form or another. England, America, and Germany, therefore, had every selfish inducement to reform and perpetuate rather than to revolutionize the existing system, not only of Turkey in Asia but of Turkey in Europe. If the worst should come to the worst, as was thought and even proposed, trial might be made in Macedonia, as it had been made in the Lebanon and Syria, of a Turkish governor responsible to the powers through their ambassadors at Constantinople. Of course this would have been the assumption by the powers of almost complete responsibility, but it seemed a preferable alternative to that of opening the sluiceways of international rivalry among the Balkan States.

These states-Rumania, Bulgaria, Servia, Greece, and Montenegro-were, as has been remarked, most interesting political specimens, well worth a careful study as instances of the past in the present, of peoples working out in the twentieth century and in the Orient problems almost identical with those which occupied the West some two or three centuries ago. Neither individually nor collectively did they seem ripe to as- 
sume any further obligations than the weighty ones which already oppressed them. Their primitive conceptions of finance and administration, above all of international relations-indeed, even their rudimentary notions of what a state and a nation is-could one and all be enlarged and matured only by experience. They were not ready, as the event has proved, to solve the world problem of Constantinople and determine the destiny of the Levant. But they believed themselves to be, and had the presumption to make the effort. Their failure was due to their imperfect, almost rudimentary, development, as can be understood only by the patient consideration of their evolution. 



\section{III}

\section{THE BALKAN PEOPLES}





\section{III}

\section{THE BALKAN PEOPLES}

Of prehistoric man in the Balkan peninsula, little is known except from a few excavations, which make us familiar with his rude buildings, his graves, his ornaments, and some utensils that have withstood the ravages of perhaps thirty-five centuries. The dawn of history reveals the Illyrians on the Adriatic, the Thracians to the eastward south of the Danube, and the Scythians north of that river.

If, as is held, the primitive peoples were roundheaded and of the Mediterranean type, the Thracians, (I) Historical Survey of whom we have portraits in relief carved in stone, were of the North-European type. Their headdress, body garments, and trousers were elaborate in fold and design, the legs being clad either in wide, flowing pantaloons that hung in carefully arranged creases, or else in tight-fitting garments, equally elaborate in creasing and giving the effect of the leggings familiar to us as puttees. The garb of the Rumanian and some of the Servian peasants to-day is but a slight modification of the Thracian clothing combined with the Roman tunic. The ancient and modern footgear are identical, a sort of laced moccasin, styled, in the Slavic tongue, opankas. The elaborate Thracian hair-dressing also survives. Among the Thracian stocks were the Trojans, Dacians, and Getians, the Phrygians, Moesians, and Lydians. They were a numerous and mighty people, penetrating the Balkans as far as Boeotia and Attica, whence they were expelled by the Ionians.

The

Thracians 
The

Scythians

The

Illyrians

The word "Scythians" is frequently used to designate those Mongolians who overran northern India, but the great and powerful people here under consideration were, like the Thracians, a North-European stock who came, according to the latest indications, from the Baltic. They were a fair-skinned, blue-eyed, blonde-haired race, which, driven from its seats by the advancing Germans, moved southward into the heart of Europe and thence southeastward, coming into contact with the Thracians at many points. Their clothing consisted of tunic, trousers, and shoes somewhat like those described but widely different in important respects, as can be seen from the monuments. They carried bow, sword, and lance, were daring horsemen, steed and rider being sometimes incased in rough armor. Of their many stems the Parthians seem to have been the most important. They were not akin to either Finns or Turks. As they are portrayed in sculpture, and from the remains found in their excavated graves, they were clearly a northern folk. Experts declare their customs to have resembled those of ancient Germans, including the blood-covenant, the deification and worship of the war-god in the form of a sword, the sacrifice of horses, the drinking from skulls, and the use of twigs and beef-collops in augury. Similar, also, was their savagery in battle.

Of the third and possibly most important immigrant stock, the Illyrians, much less is known. They were Indo-European, they came from the north, and they completely occupied what to-day is Servia, Croatia, Dalmatia, and northern Italy. Many contend that they partially settled the entire Balkan peninsula, but there is no proof. The names of about a dozen Illyrian tribes occur in classical literature, the Venetians, Iapy- 
gians, and Liburnians being the most important. Their southward movement appears to have been arrested by the fact that the southern end of the peninsula was already occupied by an earlier people, the Hellenes or Greeks.

This earliest traceable immigration of settlers into the Balkan peninsula occurred probably about three thousand years before our era. The immigrants, we repeat, were of Aryan or Indo-European stock, descendants of Japhet. They came from the north and occupied, more or less completely, what we call to-day Transylvania, Rumania, and the entire country south of the line drawn from the head of the Adriatic eastward to the mouths of the Danube. Crossing the Bosporus, they spread over much of Asia Minor likewise. As classical antiquity knew them, Thracians, Scythians, Illyrians, Epirotes, Trojans, Phrygians, Mysians, Paphlagonians, and Armenians, one and all they were so split into clans and tribes that they never formed a national unity, as this word is now understood, nor played a role in history.

The Persians overran the lands of all these stocks as far as Adrianople in the valley of the Maritza; the The Era of Chieftains Athenians compelled their obedience in spite of stubborn resistance and guerilla warfare, at least on the shore lands where fleets could operate. During the fifth century before Christ there was established and maintained by a series of powerful chieftains a government which reduced to subjection its neighboring kinsfolk, who were tribes of rude hunters, living by rapine and plunder, compelled their obedience, and enforced primitive law. This was the dynasty of the Odryses; its seat was the Maritza valley and its most powerful monarch was King Teres. The dynasty was

Early

Immigration (1) 
overthrown in B. C. 383 by a clan chieftain of the same blood, known as Kotys. At his hands the Athenians suffered repeated defeats. The day of his dynasty was short, and tribal rivalries overthrew what semblance of government there was.

Then appeared on the scene another conqueror, who, like his predecessors and contemporaries, had founded a kingship, but further south in Macedonia, where the dynasty of Macedon, so eminent in history, had been established. This was Philip II. His will was so strong and his discipline so severe that troops of the Thracian-Illyrian stock proved invaluable to his descendant, Alexander the Great, the world-conqueror of the epoch. This strange youth, possessing alike all the primitive virtues and all the primitive vices of his race, their zeal, their faith, and their energy on the one hand, their self-indulgence, their fury, and their recklessness on the other, this commanding genius was by the intellectual training of Aristotle so imbued with Greek culture that his military triumphs carried a high Hellenic civilization into all the lands which came under his way.

When the master died and his generals established themselves as kings in various parts of his empire, the upper Balkan peoples threw off all restraint, reverted to their original clan system, and so weakened themselves and their resources that when, a century later, the Celts appeared in what are now Bosnia and the Herzegovina, no effectual resistance to the new Aryan invaders could be made. Many of the earlier settlers fled before them and founded south of the Narenta a government of some stability; the rest were oppressed almost to annihilation.

But the lordship of the Celts was brief, for, after 
the second Punic War, Roman legions appeared on the scene. The process of conquest was hard and weary. Coming of Finally in B. C. 167 King Genthios, who ruled south of the Narenta, was defeated and captured. A loose confederacy of the clans, dwelling north of that river and known as Dalmatians, had been formed to repel the Romans and proved to be an even more stubborn foe; it was not until B. C. I87 that the resistance of these tribes was overcome by L. Scipio, the proprætor of Illyria, and their lands incorporated into the Roman province of that name. The resistance of the Pannonians and Dalmatians was not entirely crushed until some six years after our era. Simultaneously, Lucullus and Crassus had overrun the eastern stock and combined the lands between the Danube, the Balkan Mountains, and the Black Sea into the province of Moesia. The Roman conquerors at both extremities of the peninsula, keenly alive to the importance of easy transportation, kept persistently building their famous military and commercial highways; they likewise taught the peoples how to wrest wealth from their fields and mines, and how to enjoy it by the adoption of Roman manners and culture.

The Greeks lost their political independence when in B. C. 146 Mummius conquered Corinth. Their political activities were not in the least diminished by that fact. Their country became the base of operations Interweaving of Greek and Roman Influence alike for the tremendous struggles of Rome in the conquest of the Orient, as well as for the civil wars which masked the death throes of the Roman commonwealth and the rise of the Roman empire. The influence of Greece had been great throughout the period of the republic; in politics, literature, and all the arts of refined living she gained and retained the mastery. 
Her pupil was, however, prominent in war, in jurisprudence, and in administration-and that to the last. But in the theory, art, and practice of both social and political life Rome was Hellenized, to the menace of all the severe and primitive Roman qualities which had made her supreme.

After the battle of Actium, Greece was incorporated into the empire as the province of Achaia. Her soil had been ravaged by the perpetual warfare of a century; her population, unable to support itself by agriculture, flocked to the towns in immense numbers to seek and find employment, while the impoverished few who remained on the land became a tenant peasantry. It was an age of elegant, luxurious living; the townsfolk throve on the industries contributing to such an existence; those in whose hands great country estates had accumulated spent little time at home, and the countryfolk steadily degenerated into rude drudges and boors under the exactions of hireling managers. The coast towns and some of the inland cities cultivated the applied arts in manufactures, exporting exquisite products into all lands; and their Roman masters used every effort to promote such a commerce.

It was in the cities that the political instincts of the Greeks still found room for activity, and by the means above indicated they retained their leadership in thought from the Atlantic to the eastern frontiers of Roman power. The university at Athens surpassed in brilliancy those of Rome, Alexandria, and Marseilles, attracting students from all parts of the empire. The conquerors were at first disposed to severity of rule and ruthlessly exploited the Greek sources of wealth for themselves. In time, however, the closer 
interchange of relations created a better understanding and induced a milder administration. Society grew more dignified under Roman influences, family life purer; and Christianity established woman in a position of responsibility where she could exert her grace and charm without licentiousness. By the third century of our era, the Greek passion for beauty and for science had spread far and near into the primitive lands of the east. Caracalla gave Roman citizenship to all the freemen of the empire, thus diminishing its value, to be sure, but nevertheless creating a certain unity of culture thereby. And finally, when, with the inroads of barbarous peoples, Italy ceased to be paramount in influence, Rome being absorbed in the struggle for self-preservation, the rise of Byzantium secured an almost complete ascendancy for Greece in the eastern portions of the civilized world. What the eminent emperors in Rome, Hadrian, Antonius Pius, and Marcus Aurelius, had begun, namely, the furtherance of literature and the fine arts by imperial support, was continued by those who ruled at Constantinople as a matter of course, as a part of their official prerogative and duty. This action was so progressive and efficient that at last Athens was forced to yield her palm of leadership in culture to the city on the Bosporus.

While the southern portions of Eastern Europe were thus more or less completely Hellenized by the Rome in North Europe intellectual power of Athens and Byzantium, the case was far different in the northern ones. As has been seen in another connection, there is a wide divergence of opinion as to the ethnic character of the people known to-day as Rumanians. The name indicates to those who bear it a Roman descent, as the language they speak is unquestionably of Roman origin in its 
essential quality. To the contention of Latin birth, neither history nor anthropology gives decisive support; quite the contrary. The so-called historic evidence is altogether indirect, and amounts to a claim that in a period of a hundred and sixty years, sparse Roman settlers, whose very existence is doubtful, modified the native population so far as to create a new race. Anthropology is as helpless as history. In Moldavia the majority are short-headed, in Wallachia, the reverse; in both the majority have clear-cut features, yet many are Roman-nosed, while quite as many have noses and lips of the Mongolian type. The mass have brown hair, but a quarter of them black; three per cent are blonde, two per cent red-haired. The brows of all are broad, and their eye-cavities large; three quarters are dark-eyed. Among the other quarter the eyes are gray, with here and there blue ones. Such indications afford no satisfactory solution. But that, antecedent to the third century of our era, Roman influence was there paramount admits of no question. The west Thracians were as thoroughly Romanized as those to the east were Hellenized. Dacia had cultivated the Roman style to the exclusion of all other influences; from among Trajan's legionaries who annihilated the power of King Decibalus, and his later Roman colonists there may have survived powerful leaders. In any case there was a combination of all the elements into a new people, using a language molded into Roman form; this tongue, still spoken, is, however, now blended with a substantial intermixture of Slavic, Turkish, and Persian forms, words, and expressions. The Rumanians have even borrowed words and expressions from the Magyars, the Albanians, and the Russians. The use of such a tongue no more proves 
the Latin descent of the users than that of English by the various elements of the United States indicates the Anglo-Saxon descent of them all.

After Trajan's death these semi-Romanized Thracians could no longer be held in subjection; during his short reign of three years, Maximin, himself a Thracian who had risen from the ranks to the purple, maintained a semblance of order among his kinsfolk, but to the natural restlessness of the people was now added a new cause of disturbance. The Goths had settled on the northern shore of the Euxine, the Vandals had boldly entered the province, and from the great plains further beyond was pouring out a flood of humanity which pressed hard upon both from behind, breaking through in places and emptying itself into the valley of the Danube. Hadrian was forced (270-275) to withdraw his troops to the right bank of that great river and rename the province Ripuarian Dacia. The left shore to the north was thus lost to the empire, but some of the Romans and much of the Romanized population continued to dwell there. These and the traders kept the prevalent low Latin a living tongue. About the year 450 the Huns, and a century later the Avars, permeated the land, until finally there was a mechanical mixture of races, peoples, and tongues in which the old order was utterly disintegrated and the way prepared for the latest inundation, that of the Slavs, whose very name, Slave, indicates the contempt in which they were long held.

That descendants of Thracians, Scythians, and Illyrians, of Greeks and Romans too, still survive in the Balkan peninsula no one doubts. How numerous, how free from miscegenation with later immigrant peoples is, of course, a question still to be answered, 
if at all, by anthropological and linguistic studies more thorough than any hitherto undertaken. At present there is the widest difference in hypotheses and deductions, as numerous, fleeting, and unsubstantial as moths flitting around a candle. For example, the ancient Greeks believed that a fabulous people whom they styled Pelasgians had preceded them in their homes, but had been driven back into the northwestern snow-capped mountains. Accordingly, there is some fine writing to-day about surviving direct descendants of the Pelasgians. There is no credulity like that of the inchoate, undeveloped, self-styled historical literature produced within thirty years by writers from or in the Balkan States.

The Visigoth Migration

Slowly the great horde of Goths on the north shore of the Euxine had differentiated itself into two stocks, somewhat different in character and widely different in their historical career; the west, or Visigoths, and the east, or Ostrogoths. The next important migration into the Balkan peninsula was that of the Visigoths under Alaric, who actually settled in the central portion of it in 382, in 395 threatened Constantinople and pressed on into Epirus and Hellas. It is to the ruthless occupation of the mainland by barbarians that the islands of Hellas owe to this day their almost homogeneous Greek population, descendants of the Greeks who nearly fourteen centuries ago fled before this Germanic invasion. In time the invaders were more or less Hellenized and established themselves in Epirus as vassals of the emperors at Constantinople. Restless and uncertain as was their temperament, they soon began to fear lest they should be further absorbed into Byzantium, and at last withdrew across the Adriatic to their kindred in Italy. 
During the period of their settlement in that peninsula they destroyed the art treasures of the country most ruthlessly, and the process which they began was continued by the Huns, who poured their Mongolian flood along the same highway of nations. These in turn were followed by the Ostrogoths under Theodoric, who laid waste the Peloponnesus, and by the Vandals, who perpetrated every form of theft and destruction along the Greek coast line; whatever was left after this devastating process substantially disappeared under the rule of the Bulgars, who in $5 \mathrm{I} 7$ ravaged Epirus and Thessaly as far as Thermopylæ.

The Byzantine emperor Anastasius sought to protect his capital behind the wall stretching from Propontis to the Euxine, a line of defense so often mentioned in this latest period, and abandoned all his unhappy provinces to their fate. $\mathrm{He}$ and his successor, Justin, were utterly paralyzed when the Slavs, abiding their time on the south shore of the Danube, began a further advance and established many permanent colonies in the districts deserted by their former inhabitants. Justinian, however $(527-565)$, was a man of different temper, and while he left the Slavic colonists already established in their new seats, yet he inaugurated a system of fortifications on the Danube and in the interior of his empire which checked any further inroads.

The last quarter of the sixth century is marked by the further invasion of the peninsula by the Avars, a The Avar Invasion people of extremely warlike nature. Coming from their previous home between the Caspian and the Sea of Azov, they had occupied the valley of the Theiss, whence for two and a half centuries they terrorized all their neighbors. They now pushed forward into the 
east Roman empire and found their advantage sometimes in supporting the emperor, sometimes in strengthening the Slavic invasion. They, too, succeeded in establishing settlements at various places in Greece, but, in the main, the result of all this confusion was the greater and greater preponderance of the Slav element. At the beginning of the sixth century there were more Avars to the north of the Danube than beyond it, and more Slavs to the south than on the other side.

The Slavs

Pliny, in the first century of our era, makes mention of the Slavs, and in their legendary lore the emperor Trajan occupies so important a position that many have thought there must have been some contact of a peaceful nature between him and the Slavic tribes. Inasmuch as Slavic folklore expresses nothing but kindness and admiration for the Roman powers, which were afterwards their bitterest enemies, their kindly relations may have continued to the end of the fourth century. Traces of prehistorical Slav migrations and settlements have been found clear across Europe as far as Hanover, but the Germans forced them back over the Elbe. Their primitive seat appears to have been the banks of the Dnieper River in what is known to-day as southern Russia. A prevailing hypothesis makes them descendants of, or close kin to, the Scythians, but so commingled with the race stocks just mentioned that they appear to be a composite race.

The Bulgars

The Bulgars, whose seats had been on the lower Volga, were nearest in kin to the Turks. From the time of their earliest appearance they, too, assimilated themselves, and very closely, with the nomads about them, and it was Bulgarized Slavs who founded the empire which included the lands of the Danube, Wal- 
lachia, with a part of Hungary, as well as their own territory - a mighty empire which lasted for over three centuries (702-IOI4). During their ascendancy three peoples of unknown descent-the Hungarians, a Ugrian-Turcoman folk from Asia, and two Turkish stocks, the Patzinakians and the Cumanians-entered the districts north of the Danube. It was into the very heart of the vast Slavic territory that the Hungarians drove themselves like a wedge; and for generations the northern and southern groups lived in different environments and under different conditions-a fact which created and perpetuated substantial variations. In type, language, and even in basic institutions they are perhaps as much differentiated as the Spanish from the Portuguese, much less than the Italians and Spanish or any other two of the Romance peoples. It was the south Slavs who were first discernible in the Balkans during the sixth century. In the seventh they began to settle westward of the Bulgarians, occupying the Roman province of Moesia, and it was there that they first received the contemptuous name which they still bear, that of Servians, Slaves. In the eighth century they accepted Christianity, and thence, down to the eleventh century they were at best a protectorate, and more often a dependency of Byzantium. Thereupon, separate stocks began successively and successfully to assert independence, and in I 165 they were united under a dynasty which in 1222 was recognized by both the Pope and by the emperor of Constantinople. They developed a civilization which was quite remarkable; and under the Czar Stephen Dushan (1330-1335) the empire embraced, in addition to its original domains, Macedonia, Albania, Thessaly, Bulgaria, and northern Greece. This great Servian con- 
queror reached the very gates of Constantinople with a summons to surrender, but there he died; and his lands, united only by his imperious will, fell apart, a prey to warring ambitions. It was in 1453 that Mahomet II, the great Osman Turk, mentioned in another connection, after capturing Constantinople, marched onward with his invincible horde and soon brought all the Balkans under Turkish sway, a grinding tyranny that lasted nearly four centuries.

The Turks

With the appearance in the Balkan peninsula of the Turks, an outline of whose career has already been given, the long roll-call of national and race elements in that distracted portion of Europe is completed. Not one of these elements has remained entirely pure. Of those considered, four have admitted alien strains, and the same is true of their languages and institutions; yet all survive, and all hold fast to their traditions, and all look forward to the restoration of their ancient dominion and glory. The situation is complicated by the strife of confession; Islam with Christianity-alas! a divided Christianity-the adherents of the Greek Church, at least among the masses, regarding those of the Roman confession as utter outcasts, and vice versa. Both churches are overlaid with superstitions, and with intolerance, with dogmatic and ritualistic corruptions; but the only wonder is that after so many centuries of oppression, abuse, and degradation the common folk are not worse than they are.

(2) Racial Characteristics

Turk

Briefly to characterize these variegated stocks is difficult, but a few indications may be given, The Turk is of middle stature, strongly Asiatic in type, and disposed to obesity. In character he is serious, courteous, hospitable, and brave, but fanatical to the verge of brutality. His ethnic composition is fairly displayed 
in the ingredients of his speech, the original forms and vocabulary of which are overlaid with a mixture of Slavic, Greek, Romanic, Spanish, Persian, and Arabic elements. These last two predominate, especially in the scanty literature of the language.

The Slavs of the peninsula are generally designated Slav as Serbo-Croats. They number at least nine millions. They are a powerful race, tall and yet sturdy, with heads so domelike and short as to attract the attention of the most casual observer. The Servians are Greek Catholics and use the Cyrillic alphabet. The Croats are almost exclusively Roman Catholics. Almost all of the so-called Turks of Bosnia and the Herzegovina are Mohammedan Slavs. The districts of the AustroHungarian monarchy known as Croatia, Carniola, Bosnia, the Herzegovina, Dalmatia, Slavonia, and Istria are peopled almost exclusively by Serbo-Croats, and there are many of them in Hungary, as well as in both Trieste and Fiume. Servia proper is, of course, almost exclusively theirs, as too is little Montenegro, and there are likewise many in Bulgaria and even in Rumania, in Macedonia, and in Albania. While they vary widely in religion, in costume, and to a certain extent in habits, they speak the same language and are indisputably homogeneous in race. Their language is relatively pure, purer than their original mixed blood.

Ages of oppression did not leave the Servian charac- Servian ter unharmed. Those who professed Islam, in terror, became in time thorough Moslems and so remained. These were the great land-owners who constituted what may be, with reserve, styled the aristocratic class. They retain, as they firmly believe, the native virtues of their stock, and upon these they have engrafted those which spring from Moslem morality. The great 
mass of the peasantry, true to its Christian faith, but oppressed by the taxation which approached the boundary of confiscation, slowly became secretive and finally tricky, lazy, and untrustworthy. Their religion could not counteract the degradation of their slavery, and the comparatively short period of their emancipation has not yet sufficed to put them into even the middle rank of stalwart manliness, except as soldiers. The life of Belgrade is in many respects sadly debased, the Servians proper being an ignorant peasantry with no leadership from an upper class, and, like all others in their condition, more receptive to the vices than to the virtues of Western civilization.

Montenegrin

The Montenegrins have as yet come little in contact with modern movements and shine, therefore, in the possession of many primitive virtues. The Croatians have greatly improved under the Austro-Hungarian rule, in which they share; and the Dalmatians, still primitive in many respects, have profited much by their close contact with the refined city life in that row of beautiful towns which were once the ornament of Venetia and still retain in a high measure the refinement of Italian life. For the most part, the south Slav, the Serbo-Croat, is a man of the fields, though his women do more of the burdensome work of tillage than elsewhere in the world. Few are devoted to trade, industry, or commerce, but these few seem fairly successful. Such exploitation of the great mineral and forest wealth in their country as there is-it is as yet inconsiderable-appears to be in the hands of foreigners, who obtain concessions with difficulty and are not over secure in their possession.

Bulgarian

The Bulgarians, like others among the strata of the great confused ethnic mass accumulated by the proc- 
esses just described, were brought into the fold of the Greek Catholic Church. After the fall of Constantinople many of them became Mohammedans and are known as Pomaks, but the proportion was smaller than in Bosnia and the Herzegovina. These Pomaks have not yet returned to the Greek communion; there survive also many real Turks who may emigrate but are not likely to be converted. ${ }^{1}$ Iteration makes impression, and it cannot be too often repeated that in important times and circumstances creed has determined nationality to the exclusion of all else. It does so still in the disdainful Turkish mind, the "millet," or faithunit, being likewise a Turkish unit of administration. Thus for ages the Greek Christians were considered both an ecclesiastical and a political unit. The Slavs, once under Turkish rule, held in abomination such a concept; they have been the intermediary through which the antipodal notion has prevailed: language has been associated with creed as the test of nationality. Bulgaria is struggling to emphasize slight differencesdifferences which seem negligible to curious outsiders, such, for example, as the place of the article, or rather particle, prefixed or suffixed, or the use of Old Slavic in the service book of the church, or the designation of an ecclesiastical overseer as Exarch instead of Patriarch; not only struggling, but almost exhausting itself in the struggle to make these serve as a sanction for a nationality ambitious to control the Balkan peninsula. In this, the un-Aryan, central Asiatic origin of the people reveals itself; the tribal concept is the stirp which, running under the surface, sends up hardy shoots at unexpected intervals. The notion of a nation-

1 Some estimates place the Moslem population of the new Bulgaria as high as 450,000. The patriots hope for the re-conversion of the Pomaks, who are fullblooded Bulgarians; more dispassionate observers are very doubtful. 
ality, based on both language and creed, Bulgaria has observed to the exclusion of every other; Servia, on the other hand, emphasizes blood and social institutions as the basis for determining nationality. It also has a national church, but the Servian Church recognizes the patriarch at Constantinople as superior to its own hierarchical head, while the Bulgarian Church stops with its own exarch and knows no superior. These Vulgarians, or Bulgarians, were originally an Altaic horde, who overran large portions of the Balkan peninsula as nomads do, but were driven back by the Bosnians, Servians, Albanians, and Turks into the districts which their descendants occupy, districts then settled to a considerable extent by south Slavs. These they subjugated; but, as so often occurs when a lower overcomes a higher civilization, the conquerors adopted the religion, manners, and speech of the conquered. They began at once to merge with the earlier people and so inaugurated a process which made the Bulgarian of to-day a Greek Catholic, which gave him a pure Slavic tongue with only trifling modifications. The Bulgarian can assert a separate nationality only in his history, in slight physical traces of Altaic origin and in a slender vocabulary of Altaic words now embodied in the speech of the country.

The Bulgarians number about four millions. They occupy Bulgaria and Eastern Rumelia, which together until the outbreak of the war formed their kingdom; they have many kinsfolk in Macedonia, to the east of Albania, and some thousands in Rumania. They are of medium height and powerful build; their heads are neither short nor long, but of a middle type quite their own, and they have oval faces with rather high cheek bones. In the northern districts a few of them exhibit 
a fairly strong Asiatic type, almost Mongolian; to the southward they are more and more purely Slav. Their character is very unlike that of the Servians and Rumanians. Disposed as they are to quick surges of passion and prompt revenge, they are also intelligent, laborious, and thrifty. Like the Servians, they are a peasant folk, but both their farming and gardening are admirable, which cannot be said of the Servians. They cling to their picturesque garb, and the women's costumes glow with rich color and effective though coarse embroideries.

Scattered far and near over the Balkans is a very Wallach enigmatical folk. They are irreclaimably nomadic, living mainly by the produce of small herds of goats or sheep. In Macedonia, Greece, Servia, and Bulgaria their little bands are everywhere found on the mountainsides and upland pastures. Investigators have counted twenty-two different designations by which they are known. The generally accepted name in anthropology is that of Aromunes-goat wanderersbut they are most widely known as Vlachs or Wallachs, sometimes as Kutzovlachs. Six hundred years ago they were exactly as they are to-day. They have not advanced a single step toward a higher civilization, having neither settled habitations nor even the most primitive agriculture. In the countries through which they wander repeated efforts have been made to subdue their vagabond propensities, and at wide intervals of time and space a small proportion has been established in villages, but the vast majority still roam as before. Their racial unity cannot be doubted. In the first place, they have a physical type of their own; middle stature, round faces, coarse but regular features, straight noses, large, full mouths, brownish yellow skins and, for the 
most part, black hair. The women are most unlovely and are careless in their attire-flowing, coarse garments of skins and rough woollen stuff. Though cautious and suspicious, when reassured they are lively, good-natured, and hospitable. Secondly, they all speak the same language, the Rumanian. They speak it, of course, with variations, and these extend so far that in Rumania, Hungary, the Bukowina, Russia, and some parts of Bulgaria and Carniola, their speech is called "Dacian Rumanian"; in Macedonia, northern Greece, Epirus, Albania, Servia, Bosnia, and other parts of Bulgaria it is styled "Arumanian;" in Istria and round Fiume, "Istrorumanian" and finally to the north of Salonica, "Meglen."

But these variations do not prevent the intercourse of all the stocks with each other, and the language, though composite, is a unit. Its three basic elements are, in the order of importance: Dacian, Latin, and Bulgarian, with a very considerable intermixture of Greek, Turkish, and Hungarian. Their garb is substantially identical, too, in all places, and utterly different from that of those among whom they mingle. Both men and women wear woolen jackets, pelisses of fur or skin, embroidered shirts (those of the males short, of the females long) over drawers and trousers, with laced sandals of leather, and leggings; the headdress is generally a fur cap, sometimes peaked, sometimes flat. They have the same skill as had the ancient Thracians in folds and plaits, and their passion for color produces a revel of shrieking contrasts. Sometimes the women wear felt hats, flat or tall, sometimes hoods with ribbon streamers, or again no headdress at all, in which case their hair is drawn straight back and plaited. They are still a prehistoric folk, living like 
Troglodytes, using hand mills and clay ovens. They squat in sitting, shake the head in affirmation, and nod in negation.

This extraordinary stock is, of course, most numerous in Rumania itself, the kingdom formed from the one-time Turkish provinces of Moldavia and Wallachia and now including the Dobrudja. Within this kingdom and in Hungary much has been accomplished in raising the living standard from that of the nomads who dwell without. Village life has been established, a firm government inaugurated, education regulated and improved, agriculture introduced. The land was from immemorial times in the possession of feudal owners, and the aristocratic families still give direction to the life and customs of the peasantry. For the most part they have been under Russian influence for generations, and have north Slavic blood in their veins, as well as north Slavic ideas in their minds. With great pride in the Roman origin which they claim, they turned after their emancipation away from Russian influence and the Turkish yoke toward French sources of culture. The refinements of French life have been widely introduced among them-in some cases and in certain ways to the advancement of a real civilization, in other ways and degrees to excesses due to moral unripeness.

The Albanians! This extraordinary folk is the rid- Albanian dle, the puzzle, the mystery of both science and politics in southeasten Europe. They populate a district of most uncertain boundaries, broadly styled Albania, almost to the exclusion of any other race element; within its limits Slavs are very rare and Slavism is detested. Some Albanians are Roman Catholics and despise Greek orthodoxy, alike that of the Slavs on 
their borders and that of their kinsfolk in Greece; many more are Moslems and loathe Christianity. There are north Albanians having very little intercourse with south Albanians. Within the uncertain boundaries of Albania they number but a quarter of a million, all told; it is likely that there are ninety thousand more in Greece, Italy, and elsewhere. In matters social and political they appear to represent a development arrested centuries ago, if not in prehistoric times. They are in the tribal stage, in some places in the patriarchal. They have the point of honor developed to the verge of absurdity, and each carries on his person a small arsenal of arms and ammunition. They shave their heads close, except for one untonsured circle on the crown; here is left the traditional hair plume which is the badge of their nationality. They wear gaudy and embroidered garments, which are often neither clean nor whole, and they strut the earth like lords. They have been called the armed children of Europe.

Yet they are admirable as tillers of the soil, obstinate in the defense of their rights, courageous as few others, passionate in their patriotism, loyal to their chiefs, and hospitable to strangers who learn and observe their ways. They are of middle stature and spare frame, lithe and active, and are in almost equal proportion blonde and brunette. They regard themselves as one people because they have one territory and one language, one tradition, and, as they believe, one origin. The Skumbi River divides the Ghegs of the north from the Toscs of the south; and though the dialects of the two differ so widely as to make intercourse difficult, yet the differences are those of forms and expression, not of grammar and vocabulary. The 
language is made up of very diverse elements. Of the 5, I 40 principal words, about one half are importations; 1,420 are Rumanian, I,180 Turkish, 840 Greek, and 540 Slav; less than 400 are taken to be of ancient Illyrian origin.

The name "Albanian" was given to them by the ancient Byzantines. Their designation for themselves is "Skipitari" - the eagle's brood. Among the Ghegs there are living about equal numbers of Mohammedans and Roman Catholics, but the former are the aristocracy, haughty and exclusive, living like Scottish clans in their mountain fastnesses. The Toscs, on the other hand, entertain many Greek and Vlach settlers within their territory, and live on friendly terms with their neighbors. They are partly Moslems, partly Greek Catholics. The Ghegs have furnished the two national heroes: Scander Beg (1467) and Prenk-BibDoda; but the latter, after brilliant feats of arms as patriot, was drawn into the service of the Sultan and lost caste. While the Ghegs are renowned for their independence and warlike temper, the Toscs have furnished the warrior best known in our day as the Greek hero, Marco Bozzaris, who, with his Suliote band, did noble work for the liberation of the Greeks.

The generally accepted hypothesis as to the origin of the Albanians is that when the Thracians were driven from their seats they migrated westward, commingled with the Illyrians in the fastnesses of the Albanian Alps, an inaccessible, defensible range of majestic snow-capped peaks and narrow vales, where eventually a few Goths and some Serbo-Croats gained admission, and that the resultant of all these elements is the persistent, primitive, obdurate Albanian people. Their nearest kin are to be found in certain districts 
of the Herzegovina, where in type, garb, and character a few communities strongly resemble the Albanians. These recognize a degree of relationship, but are slowly being absorbed into the somewhat higher civilization arising under Austrian rule.

Although there are three confessed religious authorities, yet the Roman Catholic Albanians notoriously behave as they please without reference to the Pope, while Greeks and Moslems are alike indifferent to Caliph or patriarch. The obedience of all Albanians to any authority is dubious. They defied the Congress of Berlin, refusing to Servia and Montenegro the districts and towns of their land assigned by that august body to those states. They long preferred the slack reign of Turkish rule because for them that rule was hardly more than nominal. Now and then an army from Constantinople would best them for a time, but they were restless under control and made trouble when not left to themselves. The old Hamidian regime grossly abused its little power, but it was so feeble that it dared not impinge deeply on the tribal self-government. The Young Turks, in the effort to bring Albania into their constitutional regime, employed military force, but they succeeded only in exasperating the clans, especially the Mirdites and Mallisores of north Albania, into a resistance that could be broken only by extermination.

The Albanians are superbly built, active and enduring, ready alike for peace or for war, with excellent qualities of heart and mind. Roughly, the territory they assert as their own corresponds to the Epirus of ancient Greece. It is needless to say that learning and culture have made no greater progress in this province than they had in the days of King Pyrrhus. So hope- 
less was the effort of the Young Turks that, under pressure from the Great Powers, the Constantinople authorities were forced to abandon their scheme of amalgamation. The wild tribes of the north secured all their demands; in the south almost equal concessions were made, and Albania felt itself nearer to a united and half-sovereign independence than ever before. The bulwark of Turkey against Slav encroachments was thus outwardly maintained up to the outbreak of the war, but only by the reversal of the widely heralded policy of "Turkification."

There are two other unorganized elements of the Balkan peninsula which, although not numerous relaGypsy and tively, are actually so busy and pervasive that they are everywhere in evidence. The Gypsies are tinkers and metal workers. Generally, they are nomadic, but in Servia, Bosnia, and the Dobrudja there are numerous villages in which they regularly dwell, for the greater part of the year at least. Ragged, unkempt, filthy, importunate, they play an important role in necessary occupations which the natives disdain. Finally there are the Jews, almost exclusively of the Ashkenazi branch-peddlers, shopkeepers, money-lenders or, euphemistically, bankers. They are sternly orthodox in their inflexible ritual and dogmatic and mysterious in their business transactions. For the most part, they speak the Yiddish dialect of German and Hebrew, a tongue unfamiliar to those among whom they live. They are hated and feared; and, in Rumania, where they are very numerous, they are in some places and at some times savagely persecuted. The superstitious, ignorant folk, made to suffer at the hands of the Jews for their unthrift and recklessness in money matters, are easily roused to fury. In Constantinople and in Sa- 
lonica, and to a less degree in rural Macedonia, there are colonies of Sephardim, or Spanish-Portuguese Israelites, whose characteristics are entirely different from those of the Ashkenazi, and who generally are respected, often admired, by those among whom they live. 


\section{IV}

\section{THE BALKAN NATIONS}





\section{IV}

\section{THE BALKAN NATIONS}

The wild world of to-day is not Western America, Purpose of but southeastern Europe and the confines of Asia. It Chapter has, we trust, been made sufficiently clear that one of the causes for its lamentable backwardness is its defective and arrested social development, which, for the most part, is that of the early patriarchal state. Where it appears economically more advanced, the fact may be traced to a benevolent and concealed despotism, or at best to a half theocratic clanship or tribal form of government under some exceptional leader. The purpose of this chapter is rapidly and somewhat superficially to examine the nature of the monarchies that have been established as centers of order.

It is, of course, a platitude that in this vast area of territory, utterly unknown to the majority of intelligent men from the West, physical geography, as Environment and Civilization elsewhere, determines to a high degree the social structure of the inhabitants. Nowhere is the relation between man and his habitat closer; nowhere is politics more sternly conditioned by natural resources and climate. If there is ever to be a high civilization in the Balkan peninsula, it must, for this reason, be of a sort unfamiliar to modern Europeans, not as yet dimly apprehended by its own inhabitants, and demanding for generations to come charitable and considerate treatment from those enjoying a higher civilization without; a patient, parental behavior from the 
native statesmen who strive to guide the evolution from within. Before the onslaught of the Allies upon Turkey there was perpetual friction, there were frequent clashes with those who claimed authority, and there was much bloodshed. While elsewhere there was the hush of armed peace, among the tribesmen of Morocco and the clansmen of the Balkans there was the babble of tongues, the shouting of captains, the violence of barbarism, the menace of a spreading conflagration, which shocked the Western world as an anachronism. Warfare, so scientific in the equilibrium of its forces elsewhere, was there primitive and brutal. The chaos, it was widely believed, was due to the inflaming of local passions, of tribal jealousy by foreign agents, as part of the game of world politics played by the Western powers.

The Play of Politics

To what extent the great powers are responsible, only history, as written long hence, can determine. For instance, we are to-day fully aware of the three widely different policies which made a united Italy. These were respectively exemplified in the work of Mazzini, Cavour, and Garibaldi, and though, as we get a longer perspective, we see how their efforts converged to one result, it is clear that their aims were widely at variance. Again, the transformations in Cuba and Mexico have, in a large measure, been due, as is generally believed, to the work of daring adventurers, backed by private capital, unscrupulously concealing their motives behind such slogans as patriotism and liberty, choosing for their seat of war the frontier of a powerful and jealous nation, so that a temporarily constituted authority might be menaced with intervention and serve merely as a transition to annexation by the stronger power. 
With affairs in Morocco we have strictly nothing to do, but attention should be called in this connection to the skill with which the policing of the frontier has been made by France the pretext for the overthrow of a rude and corrupt despotism. The game in that part of the world, as played by the Great Powers just before and since the Algeciras Conference, has been a sort of double dummy with the cards open on the board. In some mysterious way, not one, but all of the players win. Germany secured a slice of the French Congo to widen her possessions in the Cameroons; France, a protectorate over Morocco, rounding out her vast colonial empire in northwestern Africa; Spain recognition as a power and an enlargement of her African possessions; Great Britain the open door. For that desirable end there were interminable negotiations, emphasized by the presence of a warship here and of an army there, and the equipment of a fleet somewhere else; but there was no overt war.

Something similar was going on between the spring of I9II and the autumn of I9I2 in the Balkans; in miniature, perhaps, but still on a sufficient scale to make Young Turkey shiver, to compel the mobilization of armies, and to force the new government in Constantinople to fulfill some few of the many promises it made when, three years earlier, Abdul Hamid had been unseated and sent a prisoner to Salonica. The earlier regime has been sufficiently described; the anxious complots of Abdul Hamid, his espionage, bribery, peculations, poses, tergiversations, and hypocrisies seemed, when the writer was a second time in the Balkans, to be working as well, if not better, than ever. The sudden overthrow of the despot was the work of men who, having long lived, as previously 
remarked, in Western Europe, at Paris, or elsewherebut unfortunately in self-contained groups, misapprehending entirely the aims and methods of European statecraft-believed they had found in the superficial observation of their surroundings, and in the perspective of distance from home, a solution for all the woes of Turkey. Remarking what slender influence was exerted in the West by religious, confessional, and even race distinctions, they conceived the possibility of melting together Moslems of every sect, Christians of all denominations, and races of every variety within the boundaries of Turkey, into a type citizen, a Turk. These were to be tolerant one of the other, were to cooperate in the creation of a modern nation, naturally under the leadership of the Turkish Moslem minority, and thus perpetuate the Ottoman empire.

Young

Turkey at the Helm

They had an elaborate plan. The first step was to secure the cooperation of an army, composed, they thought, of first-class material, and trained, they believed, by the best German teachers. Succeeding in this, they accomplished a coup d'état as theatrical and ruthless as any known to history. Thereupon they set up what they called, and what did have some resemblance to, a constitutional government-elections, parliament, checks on the crown and its functions, administrative, judicial, and military. For a few months there was the outward semblance of free institutions. During that period of deceitful calm there was no change, however, in race prejudice, nor in the wild nature of the human beings, who still sought each his own advantage in the destruction of others; who cultivated each his own traditions to the detestation of everyone else's; who had learned to despise order, because the price of order had been the endur- 
ance of an oppressive and savagely enforced rule, under commands given in ignorance and sanctioned by brutality.

Nor was there any change perceptible in the methods of administration; there were only promises. The army had made the so-called New Turkey; the generals were masters of the country. Founded on force, this new government must appeal to force at every crisis. There was no perceptible effort to promote true reform. It was frankly asserted in private circles, it could even be read between the lines of the newspapers, that the greater the apparent change in Turkey, the more persistent was its identity. It was sneeringly repeated on every side that the only single change was that for the white (silver) baksheesh, the new authorities had substituted the yellow (gold). To get anything done required ten times the secret service money necessary under Abdul Hamid, for the simple reason that there was a division of powers, and the oil in the can of bribery had more pivots to lubricate than before. Fleet and army equipment, foreign relations, constitutional adaptation, anything and everything except internal reform, occupied the attention of Constantinople and of the newspaper correspondents kept there to supply news to the Western world. The single vital problem, that of Turkey's local and tribal affairs, remained untouched.

The old disintegrating ideals were, after the revolution, more lively in action than ever. The six millions of Romaic-speaking Greeks planned, plotted, and furnished money as before for their "great idea" of an The Call of the Clan, or Racial Antagonism enlarged Hellas and the restoration of Byzantium. The Moslem Arabs of the great desert peninsula on the Red Sea demanded governors who were not licensed 
robbers, and a caliph who should be an Arab Moslem, not a Turkish half-Giaour. The Macedonians called for an end of rapine and murder. The Serbo-Croats agitated more than ever for a Great Servia. Bulgaria was keenly alive to the possibility of enlarging her borders and her prestige in the disorders which her statesmen foresaw. She, from one side, and Greece, from the other, kept dispatching their guerilla bands into Macedonia, incessantly troubling the racial and confessional waters of that distracted land. Montenegro had deep-laid schemes for an advance into Albania. Rumania alone appeared quiescent, but she, too, was brooding a plan, but lately revealed, for aggrandizement; she, too, had her agents in Macedonia, knitting up with her interests those of the wild Vlachs scattered throughout various parts of that province. All this was known at Constantinople, and was peevishly attributed to the activities of secret Russian agents. The Government, feebly constituted, though backed by an obedient army, could not supply the menstrutum to dissolve all these mutually repellent elements into even an inchoate nationality.

Optimistic Europe

The only really interesting phenomenon of the time was the curious confidence of optimists throughout Europe. They seemed actually to believe that the Balkan question had been settled for many years by this effort to "Turkify" Turkey in Europe. The German and Austro-Hungarian writers naturally were the most confident, and summoned their economic hosts to the rich trade banquet set before them. The economic struggle for southeastern Europe with its magnificent mineral and agricultural resources was to be renewed with vigor. As if to justify their confidence, the trade of German lands with all the Balkan kingdoms revived 
for a time in a most satisfactory way. Hungary was not quite so successful as Germany and Austria; having on her hands a problem similar to Turkey's and almost equally exasperating-the "Magyarization" of recalcitrant Germans, Rumanians, Slavs, Jews, and Gypsies within her borders.

The few who did not share this optimism were not disappointed when, beginning with the early spring of I9II, the race volcano exploded once again and the political earth began to quake. The origin, and in part at least, the continuance of that seismic storm were ascribed by many to the reviving ambition of a ruler who, moved by dynastic reasons, and permitted by other dynasties, had but lately changed his style of prince to that of king, Nicholas of Montenegro. The direct occasion for the incipient warfare has been mentioned; it was the discontent of the Albanian tribes who had hitherto been his bitter foes. They could not, and would not, endure the humiliations put upon them in the inchoate efforts made in their bleak and dreary home to Turkify them.

How bleak and how dreary not only their country, but that of Montenegro is, cannot be imagined; in this case, as in few others, seeing is believing. The northPhysical Facts and Features ern portion of Albania and the western half of Montenegro is a country that seems to have been cursed with barrenness. It is purely alpine, and alpine of that wilderness type known as "karst," cragged limestone weathered black. To one who has never seen the "Black Mountains" words cannot describe the forbidding, awe-inspiring nakedness of the "karst." Yet everywhere among these rocks is human society of primitive type. As the earth fires cooled, they left here and there little, irregular, volcanic funnels, varying in 
breadth from fifty to five hundred feet. These, either by natural attrition and mold formation, or by artificial filling with earth, painfully gathered by hand from the interstices of the rock, or by both means, are now fairly full of soil which, were sun and temperature more gracious, would yield fair little crops. On the lower levels, indeed, there grow the better grains and fruits, but on the inclement mountain sides there are to be seen only a kind of buckwheat, potatoes, and the coarser hay grasses.

Elsewhere than in these pockets there are scattered blades of grass, scrubby bush growth of several varieties, with an occasional growth of undaunted dwarf beech or birch, and sometimes a real tree. Here and there in this wilderness are vales of fertile soil, but as yet these are forest thickets or malarial marshes. Less frequent are stretches, a few miles long, where the tillage is admirable. The extent of these karst regions is very great; they begin as far westward as Carniola and appear at frequent intervals in great expanses over the whole of Europe south of the Danube ; but it is in Montenegro and upper Albania that the dismal supremacy of "karst" is undisputed either by nature or by man. Each successive district of Albania southward is more fertile and better tilled, but in all of them the social conditions are primitive.

Our latest state-science has determined that mountain ranges, and not river channels, form proper boundary lines. Such slopes and summits as we have described are not only a frontier, but are a naturally fortified and garrisoned frontier. The nomad herdsmen who range them are born soldiers, and each carries in his capacious belt his own arsenal of weapons and ammunition. 
It may seem utterly absurd and ridiculous that a kingdom so tiny and likewise so infertile, with a population no larger than a good-sized town, should be Montenegro Aim and Aspiration an aspirant for Servian leadership; but an aspirant it is, and for reasons which can only be explained by some account of its scanty annals. In the fourteenth century, the little district between Cattaro on the Adriatic and the high-lying lake of Scutari, some forty miles distant in the bosom of the Albanian Alps, was known, from the name of the stream which waters and drains it, as the principality of Zeta, and was a dependency of the great Servian empire, its few inhabitants being pure Servians then as they are to-day. When the great Servia was overrun by the Turks the conquerors barely penetrated to these mountain fastnesses, and in this Chernagora, or Black Mountain, principality there was a semi-independent line of chieftains, at once bishops and secular princes, under whom the defense was defiantly successful against all efforts at subjugation.

In the fifteenth century a conspicuous warrior fixed on the land the then already current name, which seems destined to permanency on the lips of its people, Chernagora, Monte Negro-Black Mountains. This Stephen founded, in 1485 , the cloister which is the nucleus of the little capital city, Cettigne, formed an alliance with Venice, and, in triumphant guerilla warfare, drove the Turks before his companies and scattered their forces wherever they appeared as invaders. His grandson was the notorious Scander Beg, a pervert to Islam, who, for a period, ruled as Turkish viceroy; but heathen rule was intolerable to the Christian folk with its tradition of heroic victory over Moslem foes, and in 1516 the bishop (Vladika) Vavil 
headed a successful revolt. It was, however, as separate clans and not as a nation, that the people repulsed their hated foes; and for a time there was a reversion to blood feuds, personal and tribal. Nothing but the renewed and powerful attack of the Turks could unite them; and the Moslem advance seemed irresistible until in the person of another bishop-prince (Danilo, I697-I 735) a barbaric bond of union was formed and every non-Christian in the land was on a preconcerted signal seized and killed. It was a rude retributionthe Montenegrin vespers of I III.

Thereupon this Danilo Petrowich, son of Peter, entered into relations of closest intimacy with another ruler of the iron hand, Czar Peter the Great, relations which, for historic and sentimental reasons, have never been broken by the successors of either. With Turkey's embittered foe on the other side, the then still powerful commonwealth of Venice, he also formed an alliance, joined ranks with hers and conducted a victorious campaign against the Crescent. He then made the episcopate hereditary in his line, the family of Nyegosh, but intrusted the secular authority to a governor who was to be second in position. This worked so ill that for a time, over fifty years ( 1625 I68I ), the governor was the superior, winning the respect and uniting the hearts of the warlike clans on the Black Mountains.

But Peter I ended this insubordination, and, a hardhitting prelate himself, led the Montenegrin forces against the Porte in the campaigns of I788-I79I, defeating the great Pasha Kara-Mahmoud at Krusa. In the fifteen long years of peace which ensued he proved as capable in administration as he had been in war, unified his people by tactful diplomacy, and in 1798 
promulgated a code of laws. But the affair of Montenegrin men is war; and wherever Russian armies fought there were the fierce mountaineers, generally under the vladika-woiwode, or bishop-prince. Peter I and his soldiers won glory in 1808 against the French in Ragusa; in I8I3-I8I4, with the help of English men-of-war, he captured Cattaro from the same foe; but at the end of the Napoleonic wars he was forced by the treaty of Vienna to abandon his longed-for access to the sea and surrender it to Austria. His people so adored him that on his death he was canonized.

Peter II was a no less amazing personage; a poet, priest, warrior, and administrator, enforcing the law, creating a legislature, ordering the machinery of state and inaugurating a school system. He was likewise the greatest poet who ever has sung in the Servian tongue. His nephew, Danilo I, was his successor. While Peter II had abolished the office of governor, the new ruler reversed the action; he resigned the dignity of bishop and announced himself as a secular prince; the style he assumed, with the assent of Russia, was prince and lord of Montenegro and the Burda. This prince was a great statesman. In the nine years of his reign, $185 \mathrm{I}-1860$, he crushed out the clan feuds, extirpated the vendetta, reformed the code and its administration, introduced the taxation of land, and established universal military service. The day was passing swiftly, alike of chieftains and hero-worship, of hereditary war-power and of particularism. The value of Danilo's reforms was twice proven; once when, in I852, the Turks threatened invasion and were withheld by the protest of Austria, and again in 1858 , when they were soundly beaten at Grahovo. On the first occasion it was the prince's gigantic strength of mind 
and body which set on foot a formidable army and led Austria to intervene; on the second, it was the prowess of an army actually made and trained by him that won the battle against Omar Pasha and a superior force. Such masterful men make embittered foes, and he was assassinated by one of his own subjects, but not before a boundary line between Montenegro and Turkey, satisfactory except in one small district, had been surveyed and established.

His nephew, Nicholas, was his successor. Born in I84I, educated in Trieste and Paris, he was called at the age of nineteen to a tremendous task: the Herzegovina had risen in revolt against Turkey, the Montenegrins were lending aid, and two famous Turkish generals, Omar and Derwish, were at the gates of Cettigne. The situation was too critical for rash adventure, and peace had to be made at Scutari, as the Powers willed. But by this time it was evident that the good will of Montenegro was of the first importance to Turkey; and Sultan Abdul Aziz not merely settled the existing boundary trouble but gave Nicholas access to the sea by the cession of Novosella. There followed twelve years of peace and of internal organization; but when, in 1876 , Servia declared war against Turkey, the fighting spirit of the still wild mountaineers was too strong to be checked, and the Montenegrin forces took the field.

Repulsed in their first encounter, they won two successive victories of the first importance, at Vucido and on the Fundina, both of which fields were bitterly contested. Russia intervened to end the conflict for her own reasons, but Montenegro felt assured of additions to her territory as indemnity. This the great powers, in the conference of 1877 , refused, and Montenegro took 
the field alone. Turkey sent her two most renowned generals, Soleiman and Ali Saib, at the head of powerful armies, to annihilate the little state. There were ten days of stubborn conflict before the Turks were forced back into Albania. At once Nicholas passed on, conquered the town and fortress of Nikshich (September eighth), captured Spush, in January, I878, and stormed the medieval fortress of Antivari on the Adriatic. Such military triumphs could not be overlooked, and by the Treaty of Berlin not only was the territory of Montenegro more than doubled, but her complete independence was formally recognized. Her recent boundaries were fixed by an exchange with Turkey, welcome to both parties. The Porte regained a part of Albania, essential to the strength of the Turkish frontier; Nicholas secured another stretch of coast land, including the one-time robber nest and fine harbor of Dulcigno. All nations have struggled with boundary questions due to ignorance of geography and imperfect surveying; one such remained unsettled between Turkey and Montenegro.

For thirty years there was peace in those rude borders. The miniature capital of Cettigne has a certain number of good public edifices and three embassies lodged in stately buildings. But its broad streets are flanked with low, one-story village houses, small and primitive. The only conspicuous shops are those of the tailors, whose windows are a revel of gold galloon and gay colors. The splendor of Montenegrin costume is exhibited in the stately saunterings of the men on the public squares. With the consent of the powers, Nicholas, as stated, has crowned himself a king. His consort is a model wife, mother, and queen, and the modest state of his home does not shock the 
still primitive peasantry who are his subjects. $\mathrm{He}$ has improved every department of public life and service, especially in the creation of an active legislature, of an improved judioiary, and of an efficient educational system. The crown prince Danilo led to the altar the daughter of an opulent Trieste merchant. His other children have married into powerful royal houses, and dynastic politics are still of the first importance east of the Leitha River and the Adriatic. The old friendship with Russia has been further strengthened, and the most conspicuous evidence of her bounties is to be found in the capital. The foreign language cultivated and spoken in Cettigne is Italian-a significant fact, as is the use by polite society of French in Bucharest, and, for the most part, of German in both Sophia and Belgrade. While in central Europe English is the foreign tongue most affected, it proves of little service to the traveler to the eastward, whether north or south, though most cultivated Russians can speak it if they will.

I have dwelt at some length on Montenegro as I did on Albania. Until I9I I they stood in armed clefiance; one the bulwark of Slavism on the south, the other Turkey's rock of defense to the northwest. For a short time the two peoples were warm friends. Those parts of Albania once Turkish and mainly Mohammedan, assigned to Nicholas by the Treaty of Berlin, or taken in exchange, were content under Montenegrin rule; the wildest clansmen of the Albanian Alps were kindly entreated when they rose in rebellion and, defeated, were refugees across the Montenegrin border. Strange and unforeseen rearrangement of relations! What was the cause? The drawing together was not a permanent one; merely a sign of the coming era in 
Turkish politics. In any case there, on an imaginary line across the great lake of Scutari, is certainly what has proven to be the weather-corner of European politics. Is it astonishing that Montenegro aspires to leadership in the great Servian movement?

The territory of Montenegro comprises about thirty-four hundred square miles, and its inhabitants number two hundred and seventy thousand. The western part to the banks of the river Zeta-Chernagora, Black Mountains, proper-is the bleak "karst," or waterless rocky-mountain land already described; the snow-capped Lortshen is nearly six thousand feet high. The eastern or Burda district is mountainous, too, but fertile and well watered; it contains the Dormitor, a peak eight thousand feet in height; within it are superb primitive forests and much wild, luxuriant vegetation. A third portion, southward and toward the sea, is semitropical and superbly fertile, awaiting only the canalization of the Boyanna River, outlet of the lake of Scutari, to be one among the garden spots of the world, as will likewise be the left or Albanian bank, so admirable is the tillage of the Albanian population on both. The wine and tobacco of certain districts are renowned.

This tiny and still indigent people of Montenegro has worked some miracles. There is already built a system of excellent highways on which motor post coaches run, and more such roads are surveyed; there are thirty post and twenty-four telegraph offices with nearly five hundred miles of telegraph line. In the capital are two high schools, one for boys and one for girls, and a normal school; and scattered throughout the country in convenient places are eighty primary schools. Two newspapers are printed in the national

The

Montenegrin Country and People 
printing office in Cettigne, and a second printer is established in Nikshich. The army system makes every male a soldier from sixteen to sixty-two, and military service is compulsory during a portion of every year. The king has a bodyguard of one hundred professional soldiers. The constitutional system, conceded by the prince in 1905, works with such impulse as a sovereign, virtually absolute, gives to it; and that is considerable. The exports are to the value of about four hundred thousand dollars, and the imports a million.

The visitor to Montenegro has a sense of its bitter poverty, which the people themselves do not feel. As was said of Greece, the estimate of the tourist depends on his point of view; amid the wild surrounding peoples Montenegro is in a state of advanced civilization, a model and a stimulus. But a Montenegrin country home! Four stone walls and a roof, thatch or slate, with no chimneys, the smoke oozing out through every cranny of the eaves, the unglazed windows and open doors. Within is a clay floor, with smoldering embers in the middle, and wide couches round about: the cattle are in a lean-to at the end, with their hoard of manure cherished like the treasure it is. Some houses are better, some worse than this faithful description, but the average is very low. The men in stately, though soiled garb, give orders and march with warrior mien; the women powerfully accomplish the work of house, byre, and field, with a minimum of assistance from their lords. The physique of the adults is fine and their vigor great, although they suffer sadly from rheumatism. The religious instincts are primitive and their church feeling intolerant. Their minds dwell on tradition and song, on the mighty deeds of their ances- 
try, and their tempers are easily fired to warlike energy. They are temperate in food, and, for the most part, in drink; hospitable, polite, and obliging. The best judges declare that the stranger, male or female, is safe in body and estate in the remotest districts, though others are not of this opinion. To a rude peasantry like this, the meanest house in Cettigne with chimneys, glass windows, tight doors, and plastered walls seems a palace in comparison with their own hovels. The self-complacency mirrored on the faces of the dwellers in the capital is charming.

On the southern frontier of Montenegro are the Grecian Aims Albanians, who have secured at the hands of a Euroand Influence pean conference the final delimitation of their frontiers by an international commission. North and south and beyond lie the districts which are already partly Greek and destined apparently to become entirely so. Modern Greece owes much to the Albanians, who, during the years of their revolt against Turkey, came frequently, though spasmodically, to assist in their struggle for liberty. So grateful were the Greeks that, as previously told, they adopted as their national costume the picturesque garb of their allies. It is rather a shock to one familiar with the remains of classical antiquity and sculptures representing the exquisite garments which its refined taste provided alike for the men and women of ancient Greece, to come upon the Greek of to-day in the half-barbaric holiday dress, which his fathers adopted and which seems destined to hold its own. The tasseled tarboosh, the ruffled shirt, the gaudy jacket, the swelling fustanella, or kilt, with its hundreds of folds of soiled linen, the woollen hose, and the feet clad in Oriental, heelless shoes, turned up at the toes and adorned with a ball of wool- 
len yarn-this combination, picturesque enough in itself, does not appear exactly to express the ancestry which the Greeks of to-day claim for themselves.

When writing earlier of their origins it was narrated that the inhabitants of the Egean Isles, of some portions of the Peloponnesus, and of a few districts upon the mainland of Hellas, might well claim a fairly unmixed ancestry; but it was likewise explained how large an admixture of other race stocks there must necessarily be among them. We have enumerated no fewer than ten successive peoples overrunning and settling more or less completely portions of Hellas. After prehistoric man came the first migrations of Thracians, Scythians, and Illyrians; then successively of Celts, of Romans, of Goths, Vandals, and Huns, of Avars, Bulgars, Slavs and Turks. Nevertheless, the ages have done a marvelous work of amalgamation, and the modern Greek may probably claim to be a Greek quite as much as the Romance peoples of Europe claim to be either Celtic or Roman.

They themselves, as previously stated, estimate their numbers in Greece proper and in the Levant, including Constantinople, at twelve millions; their bitterest foes admit that in the Balkan peninsula alone they number six. The probability is that this should be increased by two, and that elsewhere there are two millions more. In the great cities of the eastern Mediterranean they are shrewd and successful merchants, and many of them have amassed enormous fortunes, which, as we have said, they liberally distribute for the promotion of Greek interests, both in the smaller and greater Hellas. But their agricultural capacities are limited and somewhat inferior. In Greece proper there are numbers of Albanians, possibly some tens of thou- 
sands, who have retained their language and their original character, altogether avoiding intermarriage with the Greeks; yet they feel themselves as Greek as their neighbors. In one respect only are these colonist Albanians and the native Greeks completely united; they are nearly all of the orthodox Greek confession, which, in the parts of Europe with which we are dealing, is a powerful bond. Of course, there are other ties, especially the common tradition of bitter hatred for the Turks, inasmuch as they are both descendants of the men who suffered from Turkish oppression at its worst. They have also in common-and this is perhaps the strongest tie-the omnipresent "Great Idea," the restoration of the Byzantine empire with Constantinople once more as its capital.

A certain rather small portion of the Greeks in Asia and Crete were, and very few still are, fanatical Moslems; of these many use the Turkish language, written in Greek characters. This fact does not altogether alienate them from their nearer or remoter kinsfolk, neither the millions in the Levant nor the hundreds of thousands in America. The islands, we repeat, including Crete and the others so lately under Turkish sovereignty, have no other inhabitants, important in numbers, than Greeks. This must not be forgotten because it makes the ultimate settlement of their fate most difficult. Those who go to and fro in that part of the world, immediately discover the undoubted national type and national character.

Every people has a right to be judged from its own standpoint. The Greeks, having really created the Greek Church, retained, when all else was lost, their passionate devotion for what was the one remaining outward expression of their national unity. The con- 
querors of Constantinople, never very sure of their position in a Christian world, followed in the administration of their conquests the line of least resistance. The Greek patriarch at Constantinople, throughout a long succession of four centuries, was always a facile tool in the hands of the Sultans who appointed him. His power was alike ecclesiastical and civil. The Greek quarters of the city became the administrative center of European Turkey. Contemptuous Islam could see only its own face reflected in other social systems; for it the communities professing the Greek faith, whatever their race or origin, were Greeks. Scattered from the Black Sea to the Adriatic, these communities were therefore administered as a nation, or nations, through the Greek patriarch by means of Phanariote agents, who, according to the manner of Oriental tyranny, were unrestrained by their masters and kept in office as long as the required taxes were paid into the Sultan's treasury. Many, if not all of these agents, enriched themselves, lived in great state, and frequently combined to resist the Sultan's decrees in their own interests. It was, therefore, not difficult for them, within the limits of their administrative districts, to subordinate everything to Greek interest. The rather stupid Slavic peoples, stupid at least in comparison with the wily Greek, were overridden and crushed into dull indifference, until they frequently professed themselves Greeks in sheer despair.

By Phanariote influence the Servian Church in I 766 and the Bulgarian a year later were subordinated to the patriarchate at Constantinople. In Bulgaria the popular speech almost disappeared from use, except in the houses of the lowly or in the privacy of the better classes; in church and school the only permitted 
language was Greek. As late as the middle of the eighteenth century there were Hellenic schools even in villages where not a single Greek resided. To assert any position whatever, it was necessary to feel, to think, and to speak like a Greek; "Bulgar" and "vulgar" were synonymous. The Servians were more tenacious, but the Bulgarians abroad, as well as at home, posed as anything but Bulgarians. It was only in a few peasant huts that the hereditary hatred for Greece and for the Greek Church was outspoken, being especially bitter against the Greek clergy, who virtually purchased from their superiors the positions which they held, and exacted the price of their simony from the poor wretches whose spiritual guides they professed to be. As if to obliterate any possible retention by Bulgarians of national character, even the literary remains of the one-time powerful Bulgarian empire, preserved in cloisters or in the patriarchate library at Tirnovo, were committed to the flames. There survived but a few popular romances and spoken tradition; from these uncertain sources a monk of Mount Athos in 1762 committed to writing what purported to be a Slovene-Bulgarian history.

Probably, however, the climax of Phanariote rule was reached in two provinces known to us as Wallachia and Moldavia, now united to form the kingdom of Rumania. In those principalities, which were in a sense frontier lands, the administrators received from the Sultan both official titles and most extended powers. Their seats were firmer than elsewhere in the Ottoman empire. For that reason, great numbers of their compatriots followed in their train across the Danube, colonized the most fertile districts, and exercised so beneficent an influence upon the half-barbarous native 
Greek

Uprisings

population that they inaugurated a process of assimilation which made those principalities more Greek than any others, except those of Greece proper. Most of the Phanariote voivodes, or princes, were able and admirable men; they founded Greek schools, introduced the use of the Greek language, provided instruction in Greek philosophy, and generally elevated the life of the towns to a high level of Hellenic civilization. But the Rumanians, like the native Servians, were stubborn in retaining their speech and institutions, so that even where the Phanariote rule (disregarding a few notorious and shocking exceptions) was generally excellent, it was probably the least acceptable.

Such considerations as these explain the pertinacity with which the true Hellenes cherished in their hearts what seems to so many the insane idea of a restored Byzantium. It was the mainspring of the rebellion which culminated in 1830 by the recognition of their independence. The church had never suffered to grow dormant the idea of restoring to its members their political liberties. Their innate capacity for trade and for administration kept them in high places. Furnished with abundant means, they sent their youth to be educated in Western lands. As early as 1796 men thus educated began to agitate. At the Congress of Vienna many plenipotentiaries were won to the Hellenic cause by Kapo d'Istrias, president of the Greek society in Athens known as the Hetairia. This association moved upon a plane rather too high for the common Greeks, and a similar one for the plain people was founded in I8I4. Its leaders proclaimed that they aimed not merely at the enancipation of Greece, but at the restoration of Byzantium, an idea which, for a hundred years, has appeared utterly fanciful. 
So effectual were the agitations of both these societies that Russia, the ever-present and persistently embittered foe of Turkey, began in I82I to heed their call. Trusting to the Czar's personal interest and privately expressed sympathies, Alexander Ypsilanti, son of a Wallachian hospodar or Grand Duke, collected a band of followers in southern Russia, marched over the frontier into Jassy, and issued a proclamation calling his kinsfolk to arms. The action was too precipitate. The foreign relations of Russia compelled her openly to disapprove of the movement. Undismayed, Nicholas Ypsilanti, the brother of Alexander, took up the banner and, in spite of every discouragement, disunion, desertion, and treason, succeeded in raising a still larger body of Greeks and Greek sympathizers. The two Pashas of Silistria and Braila collected a force for the national defense, and utterly destroyed the rebel army on the nineteenth of June. Alexander sought protection on Hungarian soil, where his exile lasted for more than six years, and was ended only by the intercession of the Czar Nicholas.

But in this case the blood of the martyrs was literally the seed of the church. The word "Ypsilanti" aroused enthusiasm among all lovers of liberty throughout the Western world, and an American city which bears the name is perhaps their most enduring monument. The Greeks themselves were aroused to unprecedented energy, and rebellion broke out in the Peloponnesus almost immediately. The Turks were thoroughly frightened; there was inaugurated that series of shocking and atrocious outrages which have been, and still are, a dark blot upon Balkan history. In mad fury, the most frightful and bloody revenge was taken upon all who had participated in the uprising, and the 
wholesale massacres of the Greeks in the island of Chios roused Europe to a pitch of enthusiasm for the Greek cause, which, in the long run, proved its most valuable asset. A flotilla of armed fishing smacks and a few larger ships, under Kanaris, annihilated the Turkish fleet in the Egean. The Mainotes surrounded the Turkish troops, drove them into Tripolitza, invested the town, and finally captured it. The first national Greek Assembly met on New Year's Day, I822. Lord Byron published his amazing verse, and together with William Müller, in Germany, fanned the philhellenic sentiment of Western Europe. For some three years the irregular Greek bands were successful in their encounters with their oppressors. The Sultan, in his despair, sought help from Mehemet Ali in Egypt, bribing the insubordinate viceroy with the promise of Crete and the Peloponnesus. Before his disciplined ranks the Greeks could make no stand; the seat of war was turned into a scene of torture, of rapine, and ruthless bloodshed; volunteers from Western Europe, who, in their enthusiasm, had joined the ranks of the wild Greeks, were fellow victims in the common butchery ; Lord Byron perished at Missolonghi and the philhellenists of the civilized world, those of England and France in particular, began to demand intervention.

Grecian Independence

Europe was weary of the Metternich system. On December I, I825, Alexander of Russia died, and his successor, Nicholas I, was hostile to the Austrian leadership. Canning took the decisive step, and the Duke of Wellington, under his instructions, negotiated an agreement at Saint Petersburg for the autonomy of Greece as a state tributary to the Ottoman empire. The French were, perhaps, the most enthusiastic philhellenes of Europe; their government was forced to 
join the movement. A fleet consisting of war vessels belonging to different powers was assembled within Greek waters. The battle of Navarino, on October 20 , 1827, was begun probably by an accident, but it resulted in the annihilation of the Turkish-Egyptian fleet. Who was to reap the advantages of this undesired and perplexing victory? The philhellenic coalition fell apart; Kapo d'Istrias, president of the Greek Assembly, was believed to be under Russian influence; a French army drove the Turkish and Egyptain force out of the Peloponnesus. Canning was dead; England, under new leadership, was jealous of both powers, and for a short period sided with the Sultan against Greece-particularly after the outbreak of the war between Russia and Turkey in 1828 . The Russians had pressed forward and were under the walls of Adrianople, where they dictated the peace of September I4, 1829. By its terms the Porte agreed to cede certain Asiatic lands, to raze several fortifications in Wallachia, and to accept the terms of an international conference held in London regarding Greece. On February 3, I830, the Powers declared the independence of Greece, and on April 24 the Sultan recognized it. Meantime Greek armed forces had met with great success in Greece itself, a success which created jealousy and suspicion among the various leaders and threatened to undo the work of the past eight years. The Greek Assembly, however, under pressure from without, selected as king of the new little state Leopold of Saxe Coburg. It was not amazing that he declined. Incipient civil war was raging in Greece; Admiral Miaulis had virtually destroyed the fleet of his own country for personal reasons; and Kapo d'Istrias was assassinated by fellow patriots at Nauplia. Thereupon 
Grecian

Consolidation

the London Conference declared Greece a hereditary monarchy and the crown was offered to Otto of Bavaria, son of King Lewis I, a most ardent philhellene.

The subsequent history of Greece is a story of its consolidation. King Otto made his formal entry into Nauplia, the then capital, on February 7, 1833. His people were splintered into factions, barbarized by their long guerilla warfare; the country was even more distracted by the machinations of foreign diplomacy; Austria, in particular, then, as for the most part since, being more favorable to the integrity of Turkey than to the establishment of strong Christian powers on her eastward frontier. In 1835 the capital was transferred to Athens; in 1837 a university was established there, and in I84I a national bank; in I850 the Greek Church was emancipated from control by the patriarch at Constantinople. When the Crimean War broke out, in I853, the Greeks naturally hoped for an expansion of their territories in Thessaly, Macedonia, and Epirus, and under Greek guidance fires of rebellion were kindled in all three provinces. Great Britain and France united in dispatching a fleet to the Piræus with a virtual command that such agitation should immediately cease; they were not ready for the dismemberment of Turkey at the hands of Russia.

This diplomatic rebuff intensified the feeling of distaste for the German bureaucratic rule of the king. Otto, moreover, was of necessity influenced to a high degree by the pressure of European diplomacy, while his people thought him utterly indifferent to their cherished plan of national aggrandizement. During his absence on a visit to a remote district of the Peloponnesus, a provisional government was organized at Athens without his knowledge, and declared the throne 
vacant. He returned, under protest, in 1862 to his native land.

The choice of the people for the succession was the second son of Queen Victoria, Prince Alfred. But this was counter to the agreement between the three protecting powers, and accordingly, in 1863 , the Danish Prince William was chosen, who ascended the throne as George I, king of the Hellenes, in 1863 . Not long afterward Great Britain ceded to Greece the Ionian Isles, but in spite of such an increase of territory, the struggle for consolidation and financial independence was for a considerable time bitter and not very successful. When, in I866, Crete rose in rebellion, it obtained money, arms, and troops from the mainland. For three years Turkey seemed to hold its own, and in I869 a European conference compelled Greece to refrain from further activity; Crete remained a part of the Ottoman empire down to the events of these latest days. Until within a very short period of time the Greek population showed little capacity for constitutional government. Ministries rose and fell with a rapidity that indicated a public feeling not marked by self-restraint; and there was an absence of financial ability, which was distressing and created great uneasiness throughout Europe. It was found necessary to put Greek finances under foreign control, and amid the ever recurring disorders in Servia and at Constantinople Greece showed such a lack of common sense in its politics and of selfrestraint in its administration, that its best friends began to despair of its ultimate success.

But all this was changed, as if by miracle, when the nation became aware of the movements in Turkey, which were sure to result in so general a disintegration of the Ottoman power, that nothing but stern discipline 
Social Life in the Balkans

and rigid self-control, calmness amid social storm, could enable it to seize its opportunity and insure that enlargement of the national borders which they felt certain would result in national stability.

The social order familiar to the West has three strata -a patrician class, a burgher and farmer class, a labor class; these, at least in America, are in perpetual flux, men and families passing easily from one to the other. Although they have comparatively little permanency, they are nevertheless continuously in grinding opposition to each other, the victory being at one time with this, again with that. It seems a most beneficent arrangement, because of the perpetual vigilance, the imperious self-restraint, the wholesale discipline required to rise to and maintain a position; the fittest have every chance, the unfit find relief in agitation. In the Balkans there is among the indigenous population at any moment, in any place except the largest towns, not one of these social factors; all, whether farmers, mechanics, traders, or herdsmen, are confused into one dead level of peasantry and hand labor. Those who emerge as popular representatives to run what is called a constitutional government do not and cannot bring their family environment with them; it is not suited for publicity, pure and simple as it may be. Officers of state and army dress and appear like their kind elsewhere, but the atmosphere of refinement does not envelope them and control them.

Even the dynasties, which the masterful people, through their chiefs and in conjunction with the dynastic powers, have mechanically set to rule over them, possess no court circle in the proper sense. There is no controlling influence of woman in her indispensable role of social arbiter. Whether a mere worldling or 
noble in a spiritual aspiration, the Western woman is in every walk of life an uplifting power commanding good manners and decency, outwardly at least; and obscure immorality is not so degrading to the world as flaunting vice. Where for ages the great we e Moslems and the harem was the sphere of feminine activity, while the Christian, the petty worker, employed his women as beasts of burden, the totality of female eclipse was disastrous; and the small folk who now compose almost exclusively the Balkan populations have not recovered from its effects. The public morals are not merely without the regulating checks of social influence, but too often they exhibit the license of a harlotry which has injected itself into the lives of certain controlling men. To what has just been said there are superb exceptions ; but without mention of the humiliating truth that the Balkan man holds the Balkan woman in low esteem, everything that shocks and grieves, in certain events which are notorious, is utterly incomprehensible.

This would not be true if the dynastic influences were strong and pure. The stage of development which the Balkan peoples have reached demands a person and a family as a standard. In one case, at least, the influences of the ruling house are strong and impure; in another, pure but weak; in a third, entirely negative as yet; and only in one are they a combination of strength and purity such as furnishes an elevating example to a peasant folk and gives them a rallying point for a national patriotism.

George, the late king of the Hellenes, was elected to his office December 22, I862, and but for his assassination would have celebrated his fifty-year jubilee in 1912. A Danish prince himself, his queen was a 
Russian princess. Their progeny is numerous; both sons and daughters have admirable characters; the family life has been a shining example; and Constantine, the new king, a nephew of Queen Alexandra and a brother-in-law of Emperor William II, has displayed many qualities which fit him for his place. Father and son have, in the main, applied themselves to the duties of their rank with diligence and ability. The government, with one exceptional moment, later to be noticed, has been constitutional; and while the modern Greeks display much of the mercurial, turbulent temper of the ancients, yet, nevertheless, in this half century important advance has been made, partly by their mistakes, partly by their own initiative due to bitter lessons, partly under the tutelage of that upper class of governments we call the great powers. The only conspicuous failure has been noted. It is in the conduct of finance, which was so wasteful that a commission of the public debt, now established and composed of foreigners, became essential.

But, on the other hand, there is peace, good order, and much prosperity within the borders of Greece, while her sons without amass and pour treasures, great, even when measured by Western standards, into her educational coffers. Approached from the west, Athens disappoints many visitors; but to those coming from the east and considering the low estate of all lands once or now Turkish, the state both of the capital city and of the country as a whole is amazing in what it is, and promises. Both army and navy, small as they are, have been reorganized and rendered efficient, and it is a tribute to national discipline that the behests of other governments which forbade their annexation of Crete and other Greek 
islands were so long obeyed. The cries of the oppressed wrung the hearts of their compatriots, but these abided their time with wonderful self-restraint, content with a complete reform, in Crete at least, under the guidance of Prince George.

Even a casual observer will note the enormous influence of Germany in Greece, intellectually and morally. Greek statesmen, on occasions, when speaking of German culture, art, and science, indulge in a turgid rhetoric, which does not ring sincere, but beneath the exaggeration of their language there is much truth. It is not without result that Emperor William spends part of every year in Corfu, that German scholars ransack Greek territories in the interest of art and history, and that Greek armaments are modeled, albeit in miniature, upon those of Germany. Yet when all this is said, it remains true that Greek royalty was in itself and until lately rather an ornament than an indigenous growth on a national life. If the dynasty maintains itself for a generation or two longer, its influence will grow stronger in geometrical ratio. If Germany be, next to the United States, the worst (or best) hated of the great nations, efforts to undermine her influence and its supports will not be lacking. There are times when the legs of the throne have tottered; but King Gecrge went far to realize his motto-" $M y$ power rests on the love of my people."

The revival of dynastic influence in Europe is striking and unmistakable. Throughout these latest wars, republican France has been true to her traditions of philhellenism and her support, moral and material, has been invaluable to Greece. But Constantine was far more effusive at Berlin than at Paris. The prospective 
heir to the Rumanian throne, Carol, son of the crown prince, has at twenty years of age just been betrothed to a Russian grand duchess, while his sister at twentyone is announced as the coming bride of George, crown prince of Greece. From the dynastic point of view there are three state systems in Europe-Roman Catholic, Greek Catholic, and Protestant. They keep fairly distinct, but Protestant princesses become Greek and even Roman Catholic in their marriages, and a common interest as well as common blood combines all three. There is a determined effort to bring dynastic influences to bear in uplifting the civilization of the Christian Balkan States. 


\section{V}

\section{THE BALKAN NATIONS}





\section{V}

\section{THE BALKAN NATIONS}

"Great IdEAs," we repeat, play an almost determinative role in Eastern Europe. The "great idea" of The Russian Russia demands for her the successorship to Byzantium, ecclesiastically as well as politically. Her cherished passion for the acquisition of Constantinople is not merely economic, but sentimental and religious. Being the foremost Slavic nation, her Byzantium would be Slavic. She has therefore always had a double aversion-that to Turkey, of which such frequent mention has been made, but likewise, as emerges from the various considerations presented in these pages, to Greece and the Greeks as well as to Rumania and the Rumanians.

Both these peoples have an enormous admixture of Slavic blood in their veins, but neither has Slavic aspirations; those of Rumania are Latin and Roman, those of Greece, Byzantine and Greek. There is no question more acute in that part of the world than the degree of influence which Russia exerts, and is to exert, either by an appeal to kinship, or by diplomacy, or by secret agitations, or by open warfare upon the various countries of Eastern Europe. To a high degree the Treaty of Kutschuk-Kainardje ( I774) long remained a public charter in the Hither East. It established Russia not merely as the protector of the Danubian principalities, but, what was far more important, of all the Greek Christians in the Ottoman empire. Somewhat later the great Cath- 
arine of Russia and the enlightened Joseph of Austria joined hands to realize immediately the establishment of a new Byzantium with Catharine's grandson, Constantine, as the ruling monarch. Austria was to have Bosnia and Servia; Russia the Crimea and Otchakoff; the Danubian principalities were to have a real independence under an orthodox ruler.

Throughout the Napoleonic epoch Russia and Austria were otherwise engaged, and for Turkey in Europe the period was one of disintegration and decay. Robber chieftains ravaged its territories at will and established virtually independent powers in its principal towns. One of these, a Bosnian Mohammedan, Osman Pasvanoglu, collected so many Turks, Bulgarians, and Albanians about his standard that he even threatened to overthrow the Sultan. His star rose ever higher until I806, and his devastating conquests extended across the Danube into Wallachia. It was Russia who crushed him and thus further strengthened her influence in the principalities. It may be said that Wallachia was substantially a Russian province as late as I8I2, and that in Moldavia, Austria, preponderant at the close of the eighteenth century because of her relations with the Porte, was compelled to withdraw from both the Bukowina and the Dobrudja before the combined assaults of Russia and the Servians in I8Io. What might have happened may be guessed; but when Napoleon began his preparations for his march on Moscow, Russia made speedy terms with her foes in the peace of Bucharest, I8I2, securing the fertile and splendid province of Bessarabia. Servia obtained from Turkey amnesty for her rebels and the right at least to local selfgovernment. 
These facts explain the enormous influence of Russia in both the Danubian principalities, and what has previously been said of the Greek uprising makes clear that the Porte could no longer intrust the administration of those districts to Phanariote voivodes. In I822 Ghika was made chief administrator of Wallachia, and Sturdza of Moldavia. Both were able men and conscientious; both made Herculean efforts to introduce necessary reforms and improve in every respect the condition of the populations; but Russia looked on with deep concern, fearing the rise of an independent national feeling within two provinces containing a people so closely related, if not in language, at least in institutions and interests. She could not contemplate the aggregation on her frontiers of even moderate forces unsympathetic with her ambitions. Until 1833 the real ruler of both principalities was the Russian general, Kisseleff, commander of the protecting Russian forces, who actually promulgated a sort of liberal charter, although the nominal suzerainty was still in the Porte. It was by his influence that both Ghika and Sturdza lost all hold upon their place and all their influence upon the people. When the insurrection sympathetic with Greek movements broke out, Turkish and Russian troops combined to suppress it. By 1849 the old conditions were virtually restored; in both principalities new voivodes were inaugurated, and for a space of four years their efforts to relieve the general misery of the people met with fair success.

But when in 1853 the operations of the Crimean War began, Russia overran and temporarily adminisBirth of Rumania tered both principalities; and in 1854 the Austrians beset them in order to prevent Russia's advance upon the Balkans. By the treaty of Paris ( $185^{6}$ ) both 
were again restored to Turkish suzerainty and placed under the protection of the great powers. Both received new rulers, and at last it dawned upon the inhabitants of both that in their union there might be some degree of security and some hope of peace. So overwhelming was the tide of feeling that it could not be restrained, and on February I7, I859, a national assembly of Wallachians elected as their prince Alexander Cousa, who had already been chosen by a similar assembly to be Prince of Moldavia, thus creating the embryo of a new kingdom.

Napoleon III, contemplating war with Austria to emancipate Italy and to maintain the balance of power in Western Europe, discerned in this newborn "Latin" land of Rumania a possible ally, and by his influence the Sultan Abdul Medjid, on December 2, 186r, acknowledged Cousa as Alexander John I, Sovereign Prince of Rumania. Once again Russian influence attempted to thwart the creation of a Rumanian nationality, being exerted through the channel of great Russian landowners in both principalities, the boyars, who intervened and meddled with internal affairs at every possible juncture. On May I4, I864, Cousa, keenly alive to the procedures of French politics, organized his own coup d'état and promulgated a Napoleonic constitution providing for two chambers. $\mathrm{He}$ had been so faithful to the best interests of his realm that he enjoyed an almost boundless popularity. His success was therefore apparently complete, and the new administration was set going in all its departments.

But nature proved an implacable enemy to his plan of reform. In 1865 the harvests failed completely, and this, in a country almost purely agricultural, meant 
famine. The introduction of the new system, though far from finished, had already cost enormous sums, and financial embarrassment intensified the general wretchedness. A conspiracy was formed, which, on the twenty-second of February, by the aid of the army, forced his resignation, and a provisional government immediately offered the throne to Philip of Flanders, brother of the king of Belgium. That prince fortunately declined; and on April 14, I866, the second choice fell upon Prince Charles of Hohenzollern-Sigmaringen, a choice bitterly distasteful to both Austria and France. But Charles was fearless and did not hesitate to accept a very difficult and onerous task, especially for a German prince-that of upbuilding a would-be Latin state of no great size in population or extent of territory, in the very heart of hostile Slavic populations, and with the moral support of but a single great European power. As Carol I, he has piloted his ship of state through many devious channels and through many devastating storms, and has somehow managed to create both in his people and in other lands the firm conviction that Rumanian nationality is viable.

Moreover, the moral support of Germany must necessarily be of a very uncertain sort, for while dynastic politics still play their part in Europe, as we have said, yet it is, in this case, a very minor one indeed. When it is considered how very distant is the relationship between the German emperor and the Rumanian king, it will be seen that Germany's interest in Rumania, if based upon that alone, would be purely sentimental. The Rumanian nation boasts an origin far different from that of the Germans.

This question of their origin appears, even in the 
Rumanian Origins

light of the latest investigations, to be insoluble. They have a very definite theory as to who they are and whence they came, but the cold light of science shows gaps in their reasoning; indeed, is seems to show that the foundation is unsafe. It is an accepted principle among ethnographers that language is a will-o'-the wisp in their prehistoric investigations, unless used merely as confirmatory evidence. Their own conviction, to wit, that they are the direct descendants of Roman legionaries and of the Coloni of old Dacia Trajana, is untenable. In the first place, Vopiscus declares that Aurelian withdrew the Roman soldiery across the Danube out of old Dacia, and abandoned the province; in the second place, there is a period of a thousand years, which furnishes no evidence that Roman Coloni existed north of the Danube at all; finally, place names are the most persistent archæological records and of Rumanian place names, virtually none are of Latin origin. The great weight of authority is for regarding the present population as a back surge from Dacia Aureliana (Bulgaria and Servia) occurring toward the end of the twelfth century. Stated in another way, the Rumanians may have had an original ancestry of Romanized Thracians, which, in time, absorbed from the Slovenians so much of their speech and their blood that they became more than half Slavs. For this there is very considerable evidence in their folklore and folk poetry, which, according to Emil Fischer, an ethnologist, who lives and works among them, displays both Slavic and Romance temperament. He finds alike the wild passion and brooding melancholy of the true Slav commingled in almost equal proportions with the Roman's sound, yet sensitive grasp on reality. 
We have thus briefly resumed what was said in another connection in order to explain why Rumania has no overpowering, all-mastering ambition like those of Greece, Bulgaria, and Servia. Of course, they have most serious problems of their own. A large proportion of their kinsfolk reside across the Carpathians in Hungarian lands, where they are ruthlessly Magyarized. They are bitterly discontented that Russia forced upon them the exchange of fertile Bessarabia for the swampy, dreary Dobrudja.

Rumania has been at peace since 1877 . Their share in the Russian-Turkish war forms the most brilliant Rumania chapter of their history. Already, out of the most unpromising material, the Hohenzollern prince had created an excellent army. At the beginning of the war the nation was between two fires; the Turks still regarded both provinces as vassal states; the Russians looked upon Rumanians as their natural auxiliaries. The choice between the two interests was far from easy. The friendship of Russia was by no means unselfish. She had deliberately selected $\mathrm{Ru}-$ mania's territory as the scene of her impending conflict with Turkey. It was the firm conviction of most Rumanians that their ultimate doom was annexation to the dreaded empire of the north, and, in particular, they were well aware that one of their most cherished possessions, Bessarabia, was to Russia a Naboth's vineyard. Accordingly, a convention was negotiated, permitting the Russian armies to pass, with guarantee that no unfriendly act should be committed by the way.

The marching officers were keen observers, and noted, with some dismay, the enormous increase of Rumania's military strength during the eleven years 
of the new administration. Of incorporating such a force under their own command there could be no question. The Hohenzollern prince held himself ready for the event, whatever it might be, unhindered and uncontrolled by either belligerent. The Russians had met with a stubborn and unexpected resistance on their march toward Constantinople, and at Plevna they found themselves in a desperate plight. On August 5, I877, the Grand Duke Nicholas, grasping at the last straw, telegraphed Prince Charles: "Come to our help; cross the Danube where you choose, under any conditions you care to make, but come and come quickly; we are surrounded by the Turks." With thirty-five thousand admirably equipped and welldisciplined men, and a hundred and eight efficient cannons, the Rumanians advanced victoriously through Califatu, Nikopolis, Rahoba, and Smordanu. Before Plevna, Prince Charles and his men distinguished themselves in the storm of its most powerful fort, determined the final outcome of the great struggle, and actually captured Osman Pasha, the Turkish commander-in-chief. These successes were, of course, bought at an immense cost of life and property, but the price did not seem too high for the glory that had been won and its effect in consolidating the Rumanian nation; but when peace was dictated at San Stefano, and when later the plenipotentiaries met in Berlin, Rumania's reward was only the measure of the contempt which Russia felt for her. Her sovereignty obtained recognition, but she lost her most pleasant and valuable province. For this the compensation of the worthless Dobrudja was an insult.

This painful experience was stamped with European approval in the capital of Germany. By this time 
Charles and his poetess consort, now king and queen of an independent state, had made themselves type Rumanians; they had organized a modest court, the influence of which has always been profound and beneficent. The monarch had performed the double task of discovering the deeply hidden wellsprings of national life among his subjects and of developing them into a vigorous stream of national activities.

This new nation, emphasizing its Latin origins, Social and began, as if in defiance both of Slavic and Germanic culture, to cultivate more than ever the Latin style. Its social organization is, of course, aristocratic, since Economic Aspects of Rumania the great landowners have at least the dignity belonging to large estates, yet democratic Paris is the Mecca of its pilgrimages, and the French manner reigns supreme at Bucharest, whether in army, in society, or in literature and art.

The capital city has three recognizable rings of growth: the outer is mean, rural, rough, and somewhat Turkish even now ; the next is an interesting transition toward a higher style of life; and the inner nucleus is a small "city of light," like its exemplar-startling in its beauty, style, and brilliancy. In this constitution of its parts Bucharest is a microcosm of the country as a whole; at first sight unorganized, disconnected, a mechanical mixture of unrelated parts. But this, when closely considered, is in itself a characteristic quality; a long soaking of the refractory materials is required before disintegration sets in, or reintegration can commence. Yet the integration is there. This fact is largely the work of a government making and administering laws adapted to the conditions of its people, establishing and conducting a system of education quite above the average of Eastern Europe; ruling 
firmly very disparate populations; showing a brave front to its mighty neighbor on the north and its restless rival on the south; content with the nationality in sight, and eschewing the general Balkan tendency of dwelling mainly on the grandeur of a past, somehow to be reproduced in a visionary, dreamy future.

Under the most discouraging conditions, and from beginnings which were the most unpromising possible, the court, the aristocracy, and the administration of Rumania have already met and solved many problems which appeared to be insoluble. It seems likely that even the two most pressing and terrific questions demanding an answer will sooner or later find one: that of land tenure and that of the reactionary Jew usurer-questions which are a menace to the cohesion of national elements, which are a riddle to Western minds judging a far-off land from the standpoint of Western civilization, questions which must be examined on the spot to have even a glimpse of their meaning revealed. The relations between a brutalized peasantry and the rather overrefined absentee landlords are so strained as at times to threaten all orderly living throughout the kingdom. The Jew usurer is a parasite of terrible energy, threatening, in hundreds of communities, the utter extinction of enterprise and energy among the populations.

Bulgarian Beginnings

The most recent events have focused the attention of all Western peoples upon Bulgaria. At the end of the twelfth and the beginning of the thirteenth century of our era Bulgaria enjoyed a short period of independence, but by the end of the thirteenth century it was a Servian who was Czar of the Bulgars. In close alliance, the Serbs and Bulgars joined Charles $\boldsymbol{I}$ of Anjou, for the overthrow of Byzantium. Soon after 
there was a fresh migration of Tatars into Bulgarian lands, and before their assaults, the enfeebled Bulgaria was crushed. As far as there was a Slavic organization in the peninsula, Servia now assumed and kept the hegemony, until at last all semblance of Bulgarian power disappeared before the crushing victories of Sultan Murad. As was previously related, there seemed for centuries to be no Bulgarians, and least of all a Bulgaria. Longer than any other ethnic stock they groaned under the oppression of the Turkish yoke. The first symptom of reviving spirit may be observed in their literature. As early as the first quarter of the nineteenth century Bulgarian schools began to reappear. They were supplied by the efforts of Bulgarian merchants in foreign lands with fairly good textbooks. Then came the author, previously mentioned, who wrote what purported to be a Bulgarian history. In I844 there appeared the first Bulgarian periodical. From beginning to end, this intellectual uprising was directed against the Phanariotes and the aspirations of the panhellenists.

On Easter Day, I86o, the Bulgarians resident in Constantinople summoned sufficient courage to commit Religious a daring act, and declared the secession of the Bulgarian Church from the control of the Greek patriarchate. So terrified were these ecclesiastical rebels by their own daring that a large number of Bulgarians actually contemplated union with the Roman Church. It was soon evident, however, that they could not carry the mass of their people with them. Already the Pope had named an archbishop for the united Bulgarian Church, but his life was not safe from the moment he began his activities, and he finally fled. So extensive were these disturbances that on February 28, 1870, the 
Porte intervened, and founded the Bulgarian exarchate, whose high priest was to be chosen by the people and confirmed by the Sultan. Ecclesiastical was to be followed by civil and political independence.

Accession and Reign of Alexander

What with the decline and fall of Turkey, the conflicting ambitions of Russia and Austria-Hungary, Bulgarian aspirations were conditioned almost completely by intrinsic affairs. At the outset the pressure of Russia upon and her influence in the territories where Bulgarians lived were paramount. It was really by her impulse that on April 29, 1879, a national assembly of Bulgarians declared a conditional and partial independence, the establishment of a principality, and chose a nephew of the Russian Czar, Prince Alexander of Battenberg, to be the first occupant of the princely throne. His seat was so uneasy, party strife was so savage, the general temper of factions so uncertain, that on May 9, I88I, the prince declared he would abandon his task, were he not endowed with extraordinary powers for the creation of an orderly government. Two months later his conditions were accepted by the assembly.

It was immediately manifest that Russia's intention was gradually to turn Bulgaria into a province of her own. The storms of factional politics raged more fiercely than ever, and amid them there appeared the beginnings of two real parties, radical and conservative. Under a radical ministry there was organized among an intoxicated and overelated population the Pan-Bulgarian agitation, whose workings have in this latest struggle proven so disastrous to the normal evolution of a Bulgarian nation. This movement, of course, aimed primarily at the immediate incorporation of all East Rumelia, which was peopled by Bulgarians 
almost exclusively, and also of Macedonia, in part at least, into the rising Bulgarian kingdom. It was so far successful that in 1885 the Bulgarians of East Rumelia rose. Alexander appeared at Philippopolis, and declared the union of the province with Bulgaria proper.

It has never been clear how far Russia shared in these movements, nor how she viewed an evolution over which she had but little control; but the neighbor state of Servia saw in them a menace to the Balkan balance of power, and divined, what was the truth, that Bulgarian ambitions aimed at the immediate hegemony of the whole peninsula. Accordingly, the worthless Servian King Milan declared war, and within a fortnight saw his forces, if not annihilated, at least utterly humiliated. Austria intervened, and a peace was signed at Bucharest on March 3, I886, which virtually restored the status quo ante, except that Alexander was appointed governor-general of East Rumelia. The personality of Prince Alexander does not appear to have been conciliatory, and he was a foreigner, representative at that, as many Bulgarians felt in their newly awakened national consciousness, of Russian influence aiming to thwart their ulterior ambitions. In the night of August 20, I886, the Konak, or residence, of the prince was surrounded by Bulgarian soldiers, under the command of the highest Bulgarian officers, and Alexander was escorted, without ceremony, into Russian territory, whence later he was permitted to make his way to Lemberg, in Austrian Poland. Such a ruler was a broken reed, and though another Bulgarian party gained the overhand and sought to recall him, yet Russia felt him to be a weak support, and on the seventh of September he 
Accession and Reign of Ferdinand

abdicated finally. The national assembly chose Prince Waldemar of Denmark for the succession on September the seventh, but he had no inclination for the task set before him, and politely refused the invitation.

The house of Saxe Coburg has had a wonderful history, furnishing, as it did, from its insignificant political power, a series of most successful royalties. Kings and empresses, princes of the highest degree, its leading menbers, have cherished boundless ambition, and their ambitions have been realized by the use of their abundant private wealth and the exercise of their daring characteristics. It was to one of these, Prince Ferdinand, that Bulgaria now turned. The national assembly offered to him the reversion of their little throne, and on July 7,1887 , he entered upon the performance of his duties.

From among the peasant people had arisen a man endowed with great political insight, whose name was Stambuloff. To him Russian interference was intolerable; he desired complete independence for his country; he realized that the national evolution must be slow and self-disciplined; and it was under his leadership that Prince Ferdinand began to reign, and, indeed, to rule, as far as Stambuloff's policies were his own. It must not be forgotten that from first to last we have been dealing with peoples who have barely entered upon the highroad of civilization. Whatever may be thought of Russian standards in the conduct of foreign affairs and in the administration of internal ones, no one can deny that for the furtherance of her plans she has never hesitated to adopt whatever methods seemed expedient and efficient among those she desired to influence. Stambuloff was assassinated on July 15,1895 , and immediately Prince Ferdinand, 
forced, as he believed, to adopt an opportunist policy, entered into more friendly relations with Saint Petersburg. He has been permitted to consolidate the two portions of Bulgaria, to have himself crowned Czar of the Bulgarians in their ancient capital city, and while his day as Bulgarian king has been brief, yet he has exhibited certain very remarkable qualities.

The court at Sophia seems to exert but little power in securing widespread and permeating influences of Court and refinement throughout the country at large. This is no reflection upon its members, for the Bulgarians are an obdurate folk, a peasant people with peasant faults and peasant virtues. Turbulent scenes occur in their national assembly, and frequently arouse a suspicion elsewhere that government is insecure. They are, however, not much worse, though perhaps more frequent, than those which occur in the great capitals of the Western world, at Westminster or in Washington, not to mention Paris or Vienna. The Bulgarians are a testy folk, quick to cry out, quick to act; the influence of American ideas in Bulgaria has been and remains enormous, thanks to the American seats of learning on the Bosporus. As might be expected, these ideas have been exaggerated and warped until Bulgarian notions of liberty, rights, and equality are often grotesque. No wonder! Liberty under the severe restraint of law is not an initial, but a final state of mind in free government. The best-informed outsiders, however, believe and say that, on the whole, the dynasty suits the people over whom it reigns; that the court in the main sets a good example; that if the father may not be a devoted and devout Greek Catholic of the national church, the son and heir-apparent Boris is; that careful consideration is shown for the 
Bulgarian temper; that the constitutional development of politics is not hindered by the meddling of the executive to any important degree.

Sophia

If Bucharest be a type of Rumania, Sophia is no less so of Bulgaria. There is a palace, and there are other solid buildings, also a few modern streets; but the city has no pronounced architectural type. There are great avenues and an extended network of street-car lines; but the promise is greater than the fulfillment. There is an old, unkempt Turkish district not yet destroyed; there are gypsies squatted in unsavory settlements on the outskirts of the town, and these exhibit their unspeakable squalor without shame in the thoroughfares.

Sophia is a city of the future. It was not without regard to the future that it was chosen to be the capital, for its site is not far distant from the then existing southern frontier: in order to be central, Macedonia in great part was to be secured. It is but a short time since the future seemed near. The process of transformation went swiftly forward, alike as to the personalities of the Bulgarian people, their institutions, and their material expression in dress and housing. Nowhere in the Balkan peninsula is the visitor so tempted to feel that he is in the laboratory of history, where experiments are being made, some with, some without, success. Of other Bulgarian towns so much cannot be said; they remain strangely quiescent in the rudeness to which Turkish rule reduced them. In spite of the latest events, it must be admitted that of all the Balkan armies, the Bulgarian was and is the best in organization, morale, and personnel; and where there are garrisons improvement in the towns is noticeable. 
The frightful humiliations to which in the early summer of I9I3 both nation and army were subjected have been due to a type of insubordination which might perhaps be expected in so young a country; the insubordination, namely, of a prime minister and a commander-in-chief to the plain dictates of common sense; their feeble yielding to a vague and lurid national ambition, and their adoption in warfare of a brutal and barbaric system of retaliatory cruelties, which, it must be confessed, had largely been evolved by the three sets of Bulgarian, Servian, and Greek komitadjis active for so many years in the disgraceful horrors which have given Macedonia so sad a renown. Throughout the country generally the life of the people is the life of well-tilled fields and simple, peaceful villages. Education of the common sort is only fair; that of the higher type is scarcely more than embryonic. The fine designations of the Western world are used for their institutions of learning, but they do not connote even approximately the same things. The sum of the whole matter is that Bulgaria, though a child in its qualities, often very naughty, and as yet with little discipline, would be a very fine child indeed and full of promise if it could only rub its eyes and see distinctly how wild has been its cherished ideal, the "Great Idea" of the Greater Bulgaria.

The first of the nationalities whose territories were overrun by Turkey successfully to emancipate The Rise of Servia itself from Turkish rule was, of course, Hungary. The story of the struggle is a curious one. Sometimes the resistance was well organized and determined; at others there existed between conquered and conquerors a kind of half-armed peace, some districts rejoicing in 
their native rulers, while their immediate neighbors endured Turkish administration as best they might. When the long struggle ended, the recognized boundary of Turkey in Europe to the westward was the river Save. Where that splendid river unites its flood with the still more majestic Danube lay the great frontier fortress of Belgrade. The great bluff upon which it stands lent itself completely in the days of rather primitive warfare to the erection of a well-nigh impregnable fortress, comparable in the splendor of its situation only with that of Quebec. Behind this lay the land of Servia, inhabited by people more typically south Slav than any others; though converted to Christianity under Cyril and Methodius, their civil institutions had not materially changed since the primitive days of heathendom. The separate clans had each a patriarchal government, being ruled according to the law of seniority, struggling perpetually for supremacy one with the other, until at last a certain Stephen established a type of monarchy known in their tongue as the Zupanate. By the vote of heads of families, one was chosen as the first among equals, to coordinate, control, and defend the common interests of the larger community. These elder stocks have often been called an aristocracy, but they were not in the modern sense of the term. The monarchy itself was only nominal, since the limitations put upon it by the many peasant proprietors, speaking for their respective communes, reduced it in time of peace to substantial inactivity.

In the thirteenth century the Servian Church was still controlled by a Roman archbishop. It was the same Stephen I Nemanya, who subordinated it to the Greek patriarchate, instituting for Servia an arch- 
bishopric with his own son as the first Oriental occupant of the place. His official style was Sava, and his residence was Zica, where Servian kings should thereafter be crowned. Twelve bishoprics were likewise instituted, each with a Servian bishop. About the middle of the thirteenth century the Servian Church was recognized as independent, and a hundred years later the great Stephen Dushan raised the archbishop to the dignity of Patriarch. As between this church, with its spiritual power and the now self-assertive kingship, there was no difference of policy; on the contrary, almost an identity of purpose. In like measure with the rise of church and state, the successive Patriarchs had become patricians, and the patricians successfully asserted for themselves the privileges of nobles. Royalty with its associated clergy and nobility constituted, of course, a very small ruling class. All other Servians were serfs, living in a dead level of humble servitude, ignorant, stupid, and dumb.

This was the Servia which for five centuries maintained a certain identity and unity, in spite of ByzanServian Vicissitudes tine and Turkish dominion. Its power rose and fell in exact proportion to the personal character of its ruler. The feeble government of Byzantium had serious troubles alternately with Servia and Bulgaria; just as, alternately, one of the two sister states was more powerful than another. The climax of Servian strength was reached under Stephen Dushan in the fourteenth century, the depth of its humiliation under the conquering Sultan Murad. Its further fortunes were comparable only to those of Bulgaria, already mentioned; but Servia was institutionally stronger than the sister people. Its clan system was more deeply embedded in popular feeling; it preserved a 
higher degree of ecclesiastical individuality; its folklore was richer, and while it probably had no such literary efflorescence as had Bulgaria under Simeon, yet there was a literary tradition and a body of ecclesiastical literature, which aided in perpetuating a national continuity.

Just in proportion as Turkish rule was maintained with increasing difficulty by a steadily declining central power, did the local Turkish administration become more oppressive, ruthless, and intolerable. At the beginning of the nineteenth century the Servians were menaced with extinction, so brutal had the desperate Turkish officials become. It was, therefore, like the turning of the crushed worm when, in I804, a movement for self-protection was feebly organized and an appeal was made to arms. The insurgents had no thought of liberation at the outset; they wanted some guarantee for personal and material security. Naturally, Russia remarked the uprising with interest; being encouraged in its Pan-Slavic designs by the expansion of Servian rebellion, and ever ready to take advantage of Turkish weakness. The peace of Bucharest in I8I 2 provided Servia with a measure of internal and financial autonomy; the old frowning fortresses, however, Belgrade included, remained in the hands of Turkish garrisons.

Reign of Milosh

No sooner had Servian efforts been crowned with this measure of success than factional quarrels imposed upon suffering Servia the unhappy conditions under which it has ever since labored. The leaders of the insurrection were partly of noble origin, or at least boasted a family tree reaching back to the days of Servia's glory, and partly able men sprung from the stock of serfs and peasants. Of the latter, the most 
commanding personage was Black George (Karageorge); of the former Milosh Obrenovich. Russia's attention being absorbed by the Napoleonic invasion, the Turks began to wreak a bloody vengeance upon the unhappy Servians. The peasant leaders fled over the border into Austria, and finally found refuge in Russia. On the other hand, on Palm Sunday, April I I, I8I5, Milosh, who had concealed himself at home, appeared at Takovo with the old royal standard of Servia, inaugurated another revolt, made a successful resistance to the enfeebled Turks, dictated his own terms, and on November 6, I8I7, promulgated, with the consent of Ali Pasha, the Turkish governor, an autonomous constitution. Meantime Karageorge had returned, and manifestly with the intention of sharing in the new organization of his country. Under the auspices of Milosh and the Turks he was assassinated. Reference has been made to the interaction of the successful Greek uprising and the attempted emancipation of other Balkan peoples. However turbulent and unruly the Greeks were in the early stages of their liberation, they were nevertheless at heart inclined to constitutional government, and a constitutional monarchy was finally founded by them with no great difficulty. In this respect the Servian temperament was quite antipodal.

As has so frequently been noticed in peoples temperamentally and radically democratic, institutions vacillate between poorly organized local rule and general tyranny. No sooner were the Napoleonic wars ended than Russia renewed her attentions to Servia. For this reason partly, and partly because Turkish garrisons were still in Servian citadels, Milosh assumed the style and state of an Oriental despot, ruling with- 
out the semblance of constitutional government, without once referring his measures to a national assembly. There were occasional movements of protest, but such rebellions were pitilessly crushed, and often with much bloodshed. The democratic feeling of the Servians, therefore, was forced to organize itself in secret, and in this, with Russian aid, it was successful. Curiously enough, the Porte, when aware, as it soon was, of the incipient rebellion, favored it as efficiently as did Russia. By the combined action of these three agencies, what was called a "statute" was laboriously formulated, the substance of which was that if Milosh would not cooperate with a National Assembly, at least his powers must be regulated by a senate. This was promulgated in 1838 ; Milosh accepted the inevitable, and took an oath of adhesion to this ustav, as the expression of the popular will. He abdicated, however, in I839, was succeeded by his son Milan, who died a few weeks after ascending the throne, and was in turn succeeded by his apparently worthless brother, Michael III, who was compelled to abdicate in 1842 . The

Milan and Michael and Alexander

Second

Reign of Milosh and Michael National Assembly, or Skupchina, proceeded to the election of a successor. Weary for the moment of the Obrenovich aristocrats, it chose the son of Black George, Alexander Karageorgevich. He proved a fairly successful ruler, but fretted under Russian influence until, at the time of the Hungarian revolution in I848, he furnished a corps of volunteers to aid Austria in suppressing the revolt, and took his cue in public affairs almost completely from Vienna.

Between the senate, created by the statute of 1838 , and the National Assembly, there was little unity of purpose. The former was self-assertive, and in the main inclined to the support of the Obrenovich line. 
In $185^{8}$ Alexander came to an open rupture with the senate, was deposed, and when the new Skupchina met, it most unwisely recalled the octogenarian Milosh to the throne. For two years he ruled with willful ruthlessness, and in 1860 was succeeded a second time by his son, Michael III, who thus also came a second time to the throne. In the eight years of his administration he proved wiser than was expected, and important political changes took place in Servia: for the senate was substituted a council of state; a constitution guaranteed a meeting of the Skupchina at least once in three years; a general obligatory military service was introduced; and there was a substantial period of national recuperation. Many young Servians had been sent westward for their education; these were now returning, and in their young manhood began to share in the political life of what seemed a rising nationality. They, however, cherished too fondly the "Great Servia" idea, and by them was organized a more or less secret association, whose aim was the creation at an early date of a Servia, including Bosnia and the Herzegovina, arrayed in pronounced hostility against the power of Hungary across the Danube. It was the events which were taking place in Rumania that interrupted these activities, alike of the prince and his people. There was absolute unanimity of feeling in Belgrade that the Turkish garrisons must be driven out of Servia, too; street brawls between Turks and Servians became frequent, and finally Turkish cannon hurled shot and shell from the lofty fortress upon the houses and streets of the city below. Representatives of the Powers met in Constantinople; by Austria's insistency the Porte was brought first to evacuate Belgrade, and finally the other fortresses. 
On March 6, 1867, the last Turkish companies marched over the frontier out of Servia.

Milan IV Left thus in complete control of their own affairs, the Servians displayed once more to a puzzled world the cleft between two irreconcilable factions. The supporters of the Karageorgevich line in part, together with some who hoped to secure privileges they had lost under constitutional government, conspired together and assassinated Michael in the park of Topshider near Belgrade on June 29, I868. There was but one surviving member of the Obrenovich line, a young student in Paris, and he was called to the throne as Milan IV, reigning from I868 until I889.

The defeat of the Servians in their short war with Bulgaria was perhaps a perfectly honorable one, but it was a sorry counterpart to the victories they had so recently won in Turkey. Nish, Pirot, and Turn they had incorporated into Servia and plumed themselves upon their warlike spirit; but less than ten years later the most important of these towns had been surrendered to the Bulgarians, and they would have been overwhelmed except for the intervention of Austria. What with these humiliations and the shameful quarrels about the throne and in the rival claimant families, there was no possibility of a healthy evolution. Their finances were shockingly mismanaged; they had no respect for their rulers; to the traveler it seemed as if languor was their most striking quality. A kind of sullen discontent was mirrored in their faces, and they brooded ineffectually over the dismemberment of their nationality: indifferent to their own regeneration, they were deeply concerned about the hundred thousands of Serbs in Hungaria, Croatia, Dalmatia, Bosnia, Macedonia, and Old Servia, with whom no 
organic union seemed possible, and who, moreover, were not enthusiastic for the leadership of a Servia branded with so many disgraceful scars.

The events of Milan's reign do not, therefore, conAlexander I stitute a brilliant chapter in Servian history. His hold upon the people was steadily relaxed, yet he nevertheless succeeded in securing from the Skupchina a constitution of a still more modern type than that which it had previously adopted. On March 6, I889, he voluntarily abdicated in favor of his son, Alexander I, still a mere boy. When the heir ascended his shaky throne the plots and counterplots of Russia and Austria-Hungary were steadily undermining the small remainder of national morality; indeed, there was no national force, moral or otherwise. Perpetual efforts were made to amend the situation by amending the constitution. The young king chose as his consort a woman whose beauty and charm had hitherto adorned only the basest stratum of gay society. Ashamed of their queen, the ministers and their sovereign became entangled in backstairs conspiracy and debased, theatrical politics. It is only ten years since the king, the queen, the queen's brother, two ministers of state and fifty other persons were brutally murdered in the palace of Belgrade; and the woman's corpse, flung from a window onto the grassy terrace bordering the main street, lay for hours and hours for the baser sort to gloat over, until the ambassador of a foreign power, whether from a sense of guilty complicity or from compassionate humanity, intervened to give it decent burial. Whatever indictments may be brought against the private and public lives of Alexander and Draga, last of the Obrenovich line-and weighty ones would lie against them-the deed was one of shame, en- 
gendered in disgraceful conspiracy by those who lusted for power at any cost.

Peter The rival Karageorgevich line came to the throne in the person of the reigning monarch, King Peter; and after such an interval, down to the opening of the latest war, when masses were at last sometimes said over the unmarked graves of his predecessors, no one had lifted up a voice to say that the latter state of the unhappy land was better than the former. Somehow, time alone did not produce oblivion; and when, after such an interval, arrangements were made only three years ago for an official visit of the Servian king to Vienna, it proved a happy evasion of what highminded people stigmatized as a scandal, politics or no politics, that the Emperor Francis Joseph caught a heavy cold, which at his advanced age was a sufficient excuse for the postponement of the call. We cannot recollect that any personage within or without the Servian kingdom entertained even a dim suspicion of the true Servian nature, a nature which under chastisement has renewed its courage, and in many hardfought battlefields has exhibited an unsuspected capacity for discipline.

General Characteristics

After a hundred years Belgrade remains a commonplace, unthrifty town with a provincial Austrian, rather than Servian, impress. The heir to the throne is a dissipated youth of no character. The king's daughter, educated at a foreign court, is married to a Russian scion of royalty; but the rehabilitation of Servian royalty among the reigning houses of Europe has sadly halted. Corruption in public life is a widespread disease, and where money bribery is minimized, place bribery stalks unabashed. As long as a British ministry could see no shame in the proposition 
to confer a title in exchange for a vote in Parliament, it is unfair to besmirch even Servian public life on this account; yet at Belgrade the trade of politics has been on a level unknown elsewhere, unless it be at Constantinople. The overthrow of one king and the settingup of another was a matter of money, and it was the Russian ambassador in Belgrade who provided the needed funds. The whole conspiracy has been patiently traced to its sources and outlined in all its details: there is not a step for which the documentary evidence cannot be produced.

Public opinion there, as elsewhere, refuses to fix the guilt of bloodshed in high places and on great names, where national policies are concerned. Slowly but surely, at Belgrade, the red-handed criminals have one by one paid the penalties of a scandalous, unclean, shocking series of crimes. Those who profited are likely to remain under the ban, whatever diplomacy demands in the face of accomplished facts. No wonder that of all Balkan lands, poor Servia has been the least advanced, that her training in school and army was as embryonic as her visions were preposterous. Being at the mercy of a single great state, with no outlet or inlet uncontrolled by others, her economic plight has been sad; but it neither explains nor palliates her deplorable moral plight. Religion is as yet largely superstition; social organization of a modern sort barely exists, and her leaders stimulate national ambition with the exhibit of political toys and the emphasis of primitive manners as the cohesive force for a great empire! They appeared to be and in a measure still are a peasant folk poisoned by the virus of a showy civilization for which they have no receptivity. Their agriculture is rude, their manu- 
factures inchoate, their natural resources of lumber and mines in the hands of foreign exploiters. Nothing but the abandonment of false gods can restore the pristine virtues of which they boast.

This is the land which by reason of its name and its language aspires to leadership and control in the creation of the Greater Servia. The passion for this ideal among all Serbo-Croats is a species of imperial insanity. The Servians of little Servia expound it in their newspapers, they set it forth in their schoolbooks, nourishing their young on wind; it is the stock in trade of the demagogue, the theme of the rhymer, the subject of baby talk and cradle song. 


\section{VI}

\section{THE REVOLUTION OF 1908 AND ITS CONSEQUENCES}





\section{VI}

THE REVOLUTION OF 1908 AND ITS CONSEQUENCES ${ }^{1}$

THE outline of tyrannical methods given in a pre- Turkish vious chapter sufficiently indicates the character of Apathy and Oriental despotism as practiced by Abdul Hamid. Corruption Kitchen cabinets had substituted terror and spying for paternal government; farmers of the taxes had reduced the Christian peoples to despair in the provinces and had even driven the few agricultural Turks into a dull, fatalistic apathy by the same process of exaction. There was an army, but it was neither clad, fed, nor paid. Under German instruction it had been drilled into what was believed to be an efficient fighting machine, although this conviction was based rather on the native courage and fatalistic doggedness of the Turkish peasantry than upon any proof of their military efficiency.

The international commission, provided for in 1878 by the Treaty of Berlin, met and made suggestions for reforms in the European Vilayets which Turkey had been permitted to retain. The Turkish government would not ratify this so-called law, remained utterly passive, and shrewdly relied upon the reciprocal jealousies of the great powers as a guarantee against their active enforcement of their wishes. Of the then inchoate nationalities in the Balkans (Albanians were not then so considered), the Macedonians alone had

\footnotetext{
ISee Political Science Quarterly, March, I913, Dg. 95-123, Professor S. P. Duggan.
} 
received no measure of autonomy from the Treaty of Berlin. They regarded with hungry eyes the surrounding peoples who had. At the risk of repetition it must be recalled that while Macedonian villages contained for the most part people claiming to be of a single nationality, to wit, Turkish or Greek or Servian or Bulgarian, yet in each district there were villages of each variety; and that under the hideous compulsion of the komitadjis a village might be Greek one day and Bulgarian the next, or vice versa. While this "conversion" was due in the main to the exercise of shocking cruelties, yet so lacerated had the human fiber become, so hungry and so destitute the women and children, that shrewd bribery frequently served the same purpose.

Feebleness and Futility of the Powers

In I903 Austria-Hungary and Russia sent representatives to Mürzteg on October the ninth, and these well-meaning gentlemen proceeded to draw up a program for the regeneration of bleeding Macedonia. Personal representatives of these two great powers were to supervise on the spot the carrying out of reforms; there was to be a body of mounted military police under the control of some foreign general with an associated staff of officers selected by the great powers. Two years later provision was made by representatives of France, Germany, Russia, and Italy for a series of financial reforms. These had a specious appearance, but the agents of reform had no backing whatever from the Turkish officials, who were just as sullen and inactive as ever. There was only one result of all this futility: authentic news of massacre and outrage did penetrate to the Western world. In 1907 Austria-Hungary accepted as compensation for the abandonment of such pretense a concession to 
connect her railway lines in Bosnia with the Turkish one from Monastir to Salonica across the Sanjak of Novi-Bazar. Russia exhibited no feeling of outrage at this procedure, and matters went on as before. Reports from the new agents resident in Macedonia were, however, specific; British opinion was greatly stirred; and in 1908 the Czar and King Edward VII met at Reval, where a fairly elaborate program for efficient supervision and compulsion of the recalcitrant Turkish authority was devised. It is possible that the menace of the Reval program was one of the causes working for the overthrow of Abdul Hamid. This is not very likely, although it may have quickened the march of events.

We have already recounted the palace scandals of Belgrade. For five years thereafter Servian politics had no consistency and the nation drifted without effiBalkan Conditions (I) Servia cient leadership. The concession to Austria-Hungary for her Novi-Bazar railway outraged the Servians, for it rendered even more complete the possibility of domination by the Dual Monarchy in economic matters. Their hope of annexing that district in order to be conterminous with the Serbs of Montenegro vanished. In the dark pall which seemed settling upon Servia there was but one light-ray-a commercial arrangement concluded in 1906 with Bulgaria, whereby in the last resort she could find an outlet down the Danube and through Bulgarian harbors into the Black Sea. The state of Servian opinion at this juncture may be described as one of desperation. Quite otherwise was that of her neighbor Montenegro, whose advances in many directions had rendered its (2) Montepeople, after a prolonged period of peace, quite as eager for warlike advance as ever before in its history. negro 
(3) Bulgaria

As to Bulgaria, she possessed a double advantage over the other minor states of the Balkans. The founders of the new Bulgaria had been educated in large numbers at Robert College, the American institution of learning at Constantinople, where they. had been taught at least the principles of common honesty in public finance, the practice of which had kept her, in marked contrast to both Servia and Greece, mistress of her own purse and independent of foreign financial control. While taxation was not unduly heavy, its proceeds were honestly used to create an efficient army, to improve all the means of transportation throughout the kingdom and, to a certain extent, in the upbuilding of an educational system. It was in this last regard that they experienced the greatest trouble, partly because of fanaticism in the Greek Church, partly because of the perfervid zeal for politics among the young, and partly because young Bulgarians, like old ones, are extremely restive under the exercise of stern discipline in civil affairs. Naturally, the relations between Bulgaria and Turkey were strained; those with Greece were scarcely better because of their rivalry in the Macedonian brutalities.

(4) Greece

The plight of Greece in 1908 seemed outwardly sorry enough. Political factions had made consistent government impossible. Greek finances were in the iron hand of a foreign commission, and so thoroughly senseless had been the proclamation of Greek ambitions that the world looked on in puzzled wonder. Her attempts to "convert" the Rumanian Vlachs within her borders had exasperated Rumania until there was no semblance of diplomatic intercourse with her, while that with Bulgaria was scarcely better, because of the favor received by the Greek bands in Mace- 
donia at the hands of the Turkish authorities. Crete was clamoring for annexation, but the powers forced the unhappy little kingdom to maintain the status quo.

At this time the relative populations of the Balkan States in Europe were about as follows: Of Turkey, out of a total of thirty-five millions, about six; of Bulgaria, over four; of Rumania, about seven; of Servia, nearly three; of Greece, two and a half ; and of Montenegro, a quarter of a million. Their public debts were respectively in the same order: Six hundred million dollars, a hundred and two, two hundred and fifty-six, a hundred and thirty-five, a hundred and thirty-eight, and a million and a quarter dollars. When, however, it comes to estimating the revenues, the situation is quite different. Turkey had about a hundred and thirtyeight millions; Bulgaria, thirty-six millions; Servia, twenty-eight millions; Greece, twenty-nine millions; and Montenegro less than ten thousand dollars.

Matters might have been worse in Turkey and Servia and in Greece, but they were sufficiently bad to Plight of the render the great powers of the West extremely timid. The old legend of Turkey as a sick man, whose heirs were waiting to divide his fortune, might be precipitated into reality at any moment. Russia had been brought to the verge of inanition by her war with Japan. No one feared her, and in the Balkans her prestige was at the lowest ebb. Great Britain has in India and Egypt so many millions of Moslem subjects, and her commercial interests are so extended, that for long years she had done little at Constantinople but give advice and exert moral pressure. Indeed, so jealous is her control of the Mediterranean that it was her influence which kept Crete in the balance between the Porte and Greece. France, too, was utterly impotent.

Population and Finance 
After Great Britain she had become, through the enormous expansion of her African colonial empire, the ruler of more Mohammedan subjects than any other power; moreover, she was entangled in the web of Moroccan difficulties. Her financial institutions had loaned millions of dollars in the Balkan peninsula, and with her thrifty peasants in possession of the ballot, and consequently of political power, her foreign policy had become almost entirely economic and mercantile. Italy, though a member of the Triple Alliance and awake to the necessities of reform in Macedonia, was rendered inactive by her own double problem, to the southward in Africa, and to the eastward across the Adriatic. For some time the bitterness between her and Austria-Hungary had been enhanced by rivalry for the control of the eastern shore of the Adriatic. There had developed as the almost pivotal principle of her foreign policy the determination that that shore should be kept in weak hands. Thousands of Albanians inhabit Italy, and in all this seething furnace of sordid, petty politics the Albanians at home, the Albanians in Greece, and the Albanians in Italy were beginning to ask, "If a Macedonian nationality is to emerge from all these troubles, why not an Albanian?" With an Albania created, so to speak, under the Italian ægis, Italy's position across the narrow sea would be greatly strengthened.

Of Germany and Austria-Hungary we may speak in this connection as of a single great power, so thorough was their understanding and so unified were their interests. From the Ottoman government at Constantinople they had secured immense privilege. The latter already held Bosnia and the Herzegovina, and was expecting an outlet to the $\mathbb{E} g e a n$, with possibly 
a joint occupation of the Sanjak of Novi-Bazar with Turkey. This would further weaken the Pan-Slavic movement, and effectually quench the Servian ambitions for a boundary conterminous with Montenegro. The former, on the other hand, the stronger partner in the coalition, had maintained at Constantinople an ambassador, Marshall von Bieberstein, so shrewd that he virtually nullified British influence at the Porte. He wooed Abdul Hamid openly by the imperial visit of William II to Constantinople, and had finally obtained a series of railway concessions in Asia Minor which actually bade fair to put the shortest highway between Great Britain and her Indian empire into German hands. To show how enthusiastic the Ottoman empire was in its German sympathy, as late as June, 1908, Turkish subjects in the Far East were transferred from the protectorate of France to that of Germany.

For long years there had resided in Paris a number of Turks who, associating almost exclusively with The Young Turk Party each other, had finally evolved a chimerical idea that Turkey could, under proper guidance, ignore its past and emerge like a butterfly from the chrysalis suddenly and instantly into sistership with the European powers. No one doubts their sincerity, but everyone did doubt their capacity. It was, therefore, an event more startling than the sound of the firebell by night when a so-called Committee of Union and Progress, having secretly wooed the Turkish army stationed in the Balkan provinces, persuaded its generals to march upon Constantinople, depose and imprison Abdul Hamid, and mete out retrospective justice under lynch law to all Turkish notables who had supported the Hamidian regime. This revolution began on July 24, 
1908, and within a few days the Young Turk idealists of Western Europe were at the helm of affairs in their own land in the extreme east of that continent. In the retrospect of a few years, with its doleful tale of failure and humiliation, it is hard to realize the elation of spirit felt not only at Constantinople, but throughout the Western world, by honest idealists who believed that a regenerated and constitutional Turkey was not only possible, but in the process of formation. After ten years of quiescence, British diplomacy at Constantinople suddenly regained its ascendancy. The British ambassador was the most popular figure on the streets of the city; a British admiral began the reorganization of the fleet; a British agent assumed the task of rehabilitating the finances; and a British engineer was put in charge of the public works.

So swift and specious was the immediate advance that all European authorities felt forced to behave as if the gain were permanent. Not only the civil and military officials of foreign powers, but the komitadji bands alike disappeared from Macedonia, being withdrawn so that order might be restored under constitutional government. Religious liberty and racial equality were terms no longer essential, because every inhabitant of the Ottoman empire was to become a loyal Ottoman citizen. There was to be an obliteration of race and religious antipathy; there was to be an introduction of legal reforms so radical as to insure the equality of Christians before the courts and in the military services by land and by sea; the ballot was to be free. Throughout the pleasant summer months of that year there was a period of general rejoicing and complete inactivity.

As yet, Bulgaria was technically a vassal state, bound 
to pay an annual tribute to the Sultan. For years no one had considered the technicality as otherwise than a farce, but when the new government at ConstanSparks Before the Fire tinople, late in September, summoned the resident diplomats to a banquet, they deliberately overlooked the Bulgarian agent, who was not technically a diplomatist. Within a fortnight Bulgaria declared her complete independence, and when a strike broke out on the Oriental railway, in Rumelia, Bulgaria restored order and assumed the control of all Turkish railways within its boundaries. It likewise denounced the system of capitulations as no longer operative in Eastern Rumelia. This high-handed procedure was mildly deprecated by the great powers as a breach of the Treaty of Berlin, but Bulgaria retorted that she had not been a party to that compact.

With the fringes of that public charter thus mutilated, Austria-Hungary almost simultaneously announced to the world that her protectorate of Bosnia and the Herzegovina had ceased, and that those provinces were now an integral part of the dual monarchy. The Treaty of Berlin, violated from the beginning by each of its signatories, according to their respective interests, had virtually ceased to exist. The two provinces, solidly populated by Slavs, had regarded the Young Turk Revolution as a guarantee of their own freedom and of the full electoral rights which under the Austrian protectorate they had never enjoyed. For this reason they had begun an agitation and announced their aspirations as loyal subjects of the Sultan to be represented in the parliament at Constantinople. This precipitated the annexation. Russia and Great Britain were indignant and remonstrated with Austria-Hungary. To their joint note the Austro- 
Hungarian foreign minister, Aehrenthal, gave answer that no limitation had been set to the Austro-Hungarian occupation of the provinces, either as to time or to control; that his country had made enormous sacrifices for the improvement of the provinces; that their annexation was a settled matter, never to be submitted to a European congress. On March 22, I909, Germany notified Russia that if her consent were not given, Servia, having mobilized its army and called out its reserves to back a claim for territorial compensation, would immediately be invaded by AustroHungarian troops. Through the channel by which this information was conveyed there rang an imperious note; Russia submitted; Italy was bound by the Triple Alliance; England and France were pacific; all talk of a European conference ceased.

Crete thought its opportunity had come, and voted its union with Greece. This little folk, however, had so often endured serious castigation at the hands of the Powers, that it humbly asked for their sanction, which was disallowed by them immediately.

Here, then, was the Young Turk government, proclaiming the unity of the Ottoman empire, at once and disastrously stripped of two great vassal territories and menaced with the loss of a third. They dared not fight Bulgaria with arms, and least of all Austria-Hungary. As regards the latter power, recourse was had to a complete boycott of her wares; a boycott so complete that it entailed enormous losses, amply retrieved, however, by exploiting the natural resources of Bosnia and the Herzegovina. In order to end the boycott, Austria finally paid eleven million dollars as compensation for church property and other lands claimed by the Porte within these two provinces; and it was likewise a 
clever move of the Young Turks to levy heavy customs on goods from Eastern Rumelia, hitherto free from that exaction because it was nominally a tributary province. Bulgaria therefore agreed to an indemnity of sixteen million dollars payment partly for the railway and partly as compensation for the tribute technically due to the Sultan. The new Turkish government defied Greece in the matter of Cretan annexation, but gave formal assent to the annexation of Bosnia and the Herzegovina by the dual monarchy and recognized the independence of Bulgaria.

Although the central doctrine of Islam is resignation, yet from the days of Mohammed onward there Fanning the Flame have been in every Mohammedan state a party of progress and a party of reaction. The blindly fanatical, reactionary adherents of their religion were bitterly opposed to a political situation antagonistic to the precepts of the Koran. In particular, the half-savage Kurds rose in a blind fury; there was a hideous massacre of Christians in Asia Minor, and the Arabs in Yemen threatened secession from the empire. Among the rank and file of the Turkish soldiery there was, it is said, great murmuring. They could fight for a cause in harmony with their faith, but the Europeanized Turks who were leading this disastrous movement made no pretense of being faithful to the religion of Islam as the lower classes understood it. On April 13, 1909, there was an effort to oust the Committee of Union and Progress from power. Mahmud Shefket Pasha marched swiftly into the city with twenty-five thousand men at his back and crushed all opposition, establishing a military government and showing no regard for the constitution.

The general himself became minister of war. 
Educated in Germany, he intrusted the reorganization of the army to a distinguished German officer, von der Golz, and thereafter the military power was in intimate relations with the Triple Alliance. Young Turkey, nominally constitutional rulers, in reality a mere annex of the army, slowly assumed the same attitude. Fearing the partition of Persia between Russia and Great Britain, they sent troops to the Persian frontier in order to prevent encroachments on their own boundaries. Both the great powers concerned exhibited impatience and remonstrated against the action. Manifestly, too, Great Britain and France sympathized with the Cretan people in its desire for annexation with Greece. These facts went far to alienate the Young Turks from the Triple Entente; and financial ruin stared them in the face, since no assistance was to be had from any one of its three members. Without the assent of the public-debt administration there could be no increase in customs duties. Of the powers represented in that body, Austria-Hungary and Germany had combined to permit an increase of the tariff in I9IO; and had assented to heavy taxes upon alien merchants. Both of them assumed a disinterested attitude in the Cretan matter, and Marshall regained by a skillful use of these facts the position of influence which he had occupied under the Hamidian regime. Rumania and Turkey, for reasons previously given, were embittered against Greece, and in proportion as Greece and Bulgaria seemed to draw together it appeared essential that they, too, should make common cause against a power hostile to both, which was assuming portentous dimensions.

It must be said of the Young Turks that at least they had the courage of their convictions. Not for 
one instant did they relax the effort to centralize government authority; and the ruthless process of Turkification throughout the empire went steadily forward. Kurds, Arabs, and Albanians were recalcitrant because of their respective but primitive civil constitutions; the Macedonians were infuriated as they saw their hope of autonomy disappear. It will be recalled that Turkification, in itself an absurdity, was always initially thwarted by the fact that the Ottoman empire, in so far as it had an organization, was a church ruling other churches, and unfamiliar with the concept of true nationality in its most rudimentary form. The effort to strip the Christian communities of the bitterness accumulated during five centuries of oppression within a few weeks was worse than futile -it was incendiary. It was the cause of the rebellion in Albania which destroyed the Turkish bulwark against the Slavs; it brought about the renascence of race patriotism among the Albanians; it ended in humiliating surrender. Forced to grant an amnesty, the Young Turk government yielded every one of twelve radical demands formulated by the rebel Albanians. This process, moreover, as we have elsewhere said, kindled the conflagration of revolt in Macedonia.

The cup of their humiliation ran over when one of the great powers preempted its share in the disintegraItaly Adds tion of the Ottoman empire. On September 28, I9r I, Italy announced to a somewhat startled world that she was about to occupy Tripoli and the Cyrenaica; and she promptly made good the menace of her proclamation by transporting an army into Africa. The significance of this act for the government at Constantinople has not been fully understood. These were the 
only two remaining purely Mohammedan provinces of the Turkish empire. What does a Caliph amount to who has no believers over whom he may preside without the intervention of heretical states? Islam knows no distinction between civil and spiritual power; a spiritual sovereign with no secular authority is to a faithful Moslem a simple absurdity. The wayfaring man could understand, and did, that this situation had been created under Young Turkish rule. Throughout the confines of Mohammedanism there was murmuring and much discussion as to whether the Padishah at Constantinople were fit to be the spiritual head of the true believers. Islam as a system alike of spiritual and secular control was reduced to its deepest humiliation. Nothing so degrading had occurred throughout its long history.

Italy had feared lest the annexation by AustriaHungary of Bosnia and the Herzegovina would diminish, and perhaps annihilate the influence in Albania she had so dexterously inaugurated and increased. Her emigrant population could find no place of settlement except under foreign control. In the Treaty of Berlin, when other powers had enriched themselves territorially, she had received nothing. The time seemed ripe to proclaim her position as a truly great power by demanding a share in the partition of Africa which had been so diligently carried on now these many years by England, France, and Germany. The minister for foreign affairs of Austria-Hungary demanded and obtained the assurance that Italy's operations should not extend to the Balkans, and thereafter every European state regarded Italy's procedure with apparent indifference. Turkey could not dispatch troops by land to Tripoli because Egypt was in the possession 
of Great Britain, nor could it send them by transport ships, for it had no navy to protect them. The best the party in power could do was to dispatch an able general, Enver Bey, to organize the resistance of the scanty Turkish garrisons and the brave but undisciplined Arabs.

What Turkey actually accomplished was an unpleasant surprise to Italy. It so protracted the struggle as to involve Italian finances seriously. It destroyed the important trade of the Italians with the cities of Asia Minor. In short, it so crippled the government at Rome that the Italian fleet was sent to occupy twelve northern islands of the Egean and to threaten the Dardanelles in the hope of intimidating the Porte. At once the Dardanelles was closed to all ships; the door was locked in the face of Russia; the neutral commerce of the world suffered serious damage; and exasperation among the Western peoples succeeded to apparent indifference. With the sense of having at least done its best, and under the moral pressure of Europe, Turkey opened negotiations for peace in July, I9I2, and on October I 5 the treaty of Lausanne was signed by the two powers; the Porte renouncing its sovereignty over Tripoli and Cyrenaica, and provision being made for the exercise of the Sultan's religious authority among the African Moslems. The Ægean Islands were to be restored to Turkey under guarantees for reform in the treatment of their Christian inhabitants.

The situation at Constantinople had become more perplexing than ever. The best Turks seemed stupified and withdrew from all active participation in affairs. The governing Committee of Union and The Situation at Constantinople Progress was now composed of professional politi- 
The Balkans Ablaze

cians. Familiar with their task, its members, partly by thorough organization, partly by intimidation, secured in April, I9I2, a majority of faithful adherents in the Chamber; a majority, however, which did not represent public opinion, and was therefore inefficient from the outset. In July the government fell and made way for a new political group, known as the "Party of Liberal Accord." Ghazi Mukhtar Pasha assembled a group of excellent men as a ministry.

The new government immediately proceeded to punish the leaders in a riot, which had occurred in December, I9II, at Ishtib and had eventuated in a terrible massacre of Christians. Almost instantly, early in August, another atrocity of the same sort was perpetrated upon the Bulgarians at Kochana. The new ministry was thwarted in its admirable purpose to bring these latest offenders to justice and carry out a policy of strong conciliation by a chamber which had now grown hostile. The party of Union and Progress returned to power. Guerilla fighting began on the frontiers of both Montenegro and Bulgaria. Thereupon news of the Balkan Alliance reached Constantinople. In the crisis thus precipitated, Kiamil Pasha, the only preeminent figure in Turkish affairs commanding general confidence, became Grand Vizier. On October first Bulgaria mobilized its troops; the other Balkan States did likewise; and by the eighth of October there was an army of a half million foes along the north and of a hundred thousand along the south. The government at Constantinople confiscated all war material which they thought belonged to the Allies, and seized a hundred Greek merchant vessels.

Western Europe, of course, did not remain in entire ignorance. There was a general consensus of opinion 


\section{THE REVOLUTION OF 1908 ' 163}

that the inevitable struggle must be localized. AustriaHungary avowed her intention of protecting her interests in the Sanjak of Novi-Bazar, and put on foot a great army along the Danube. Russia was exasperated, and arrayed her forces upon the Galician frontier. There was real danger of a general European conflagration, but France succeeded in preventing the outbreak of any actual hostility between the great powers. Under its leadership their several governments agreed: first, to condemn any belligerent action; second, in case it could not be prevented, to permit no modification of existing territorial boundaries; third, to take efficient action for securing reforms necessary to the welfare of the Christians of European Turkey. These were embodied in a joint note presented at Cettigne on October eighth; in consequence Montenegro immediately and defiantly declared war against Turkey. This precipitancy was attributed to Russian influence. The other Balkan States presented an ultimatum to the Porte demanding autonomy for Macedonia, Christian governors for the Christian Vilayets, the withdrawal of Turkish troops and the substitution of local militia. The answer of Turkey was the declaration of war against Bulgaria and Servia on October I7, 1912; and thereupon Greece declared war against Turkey.

The course of the war displayed no carefully studied strategic plan, at least as far as the Turks were conProgress of the War cerned. After its preliminary stages, hostilities centered about the three great fortified places of Scutari, Janina, and Adrianople. Elsewhere, the Turkish armies displayed little resisting power, to the intense mortification of Germany, which had supplied them with war material and had trained them to what was be- 
lieved to be a high degree of efficiency; but in these three places the Turkish resistance was superb, commanding the unwilling admiration even of their foes. In the result it was clear that, accidental as had been this development, it had really exhausted the resources of the Allies. At the close of hostilities, experts expressed the opinion that General Savoff had made the Bulgarian army "the finest fighting engine of its size in Europe." The Bulgarian people for ten years had concentrated all its passionate effort to be ready for the inevitable struggle.

Possibly the sacrifices of the Greeks were even more remarkable. The little land had secretly accumulated a very substantial reserve of war funds. From Crete it had accepted as prime minister Venezelos, admittedly a man of the highest power as a statesman. From France it obtained a general, a number of staff officers, and the necessary artillery and equipment. As if by special grace, financial administration became thrifty and excellent. It was under Greek auspices that comparative union of purpose and action had been secured. The Servia of I9I 2 was far different from the Servia of I888. Travelers had been disposed, in view of court and government scandals, to despise the Servian morale and to belittle the fighting strength of the Servians; yet, when tested, the Servian army was found efficient. Her politicians had been sobered, her court chastened, and her recuperation completed. She, too, had somehow found or saved sufficient money to refit her offensive power. As to Montenegro, enough has been said. There is no question of people and army; these are one. Their munition, although somewhat antiquated, was more complete than had been expected; indeed, it was remarkable 
that a land so poor had accumulated war supplies at all.

The Allies had four armies, numbering in all seven hundred thousand men; Turkey had barely half the Success of number. It is now claimed that the reforms of von der Golz had been in the main theoretical and not actual; that the Young Turk government had rewarded its supporters by substituting young politicians for the former experienced officers. We hear that their system of transportation was contemptible, their commissariat worthless, and the troops themselves half starved. This may be true, but it is curious that Europe thought quite otherwise until, within three weeks after the declaration of war, Turkish military strength had almost vanished from consideration, except within the great fortresses. The theater of the war was, of course, almost entirely the mountain districts by reason of which the Balkan peninsula is designated as it is; the word "Balkan" meaning "mountains." The Greeks, Bulgarians, and Servians alike pushed forward through the frontier passes of the various mountain ranges into Thrace, Macedonia, Old Servia, Thessaly, and Epirus. The ensuing engagements were naturally and necessarily of minor dimensions, resulting in an apparently prearranged unbroken withdrawal of the Turks. This lasted for a week, when to the westward the Servians and a part of the Bulgarians pushed onward in four columns in order to gain touch with Montenegro. While the northern army of the Allies captured Pristina, pushing slowly and with difficulty onward, the southern army had even greater difficulty in reaching Kumanovo, where a junction was to be effected. They met with stubborn resistance from Turkish columns, with which 
they fought steadily and successfully for three days, from the twenty-first to the twenty-fourth of October. Again the Turks slowly withdrew, and the way to a junction of the three allied armies was opened. Ueskub and Koprulu were occupied, and soon after there was a successful advance upon the all-important harbor city of Salonica from the north. Meanwhile the Greeks had successfully pushed onward through Thessaly and were upon the edge of the plain in which Salonica stands. The Bulgarians were approaching through the valleys of the Druma and Mesta and had cut the railway line between Salonica and Constantinople.

In this way the Turkish army of the west was separated from that of the east. Everything depended upon the result of the struggle before Constantinople between the main armies of Turkey and her foes. The Bulgarians advanced in separate columns with a front stretching from Tirnovo to the Maritza River. This was a necessary risk, but the adventure succeeded. They passed the mountain range successfully, and met the Turkish enemy at Kirk-Kilisseh. Again the Turks drew off and the Bulgarians invested Adrianople. The principal Turkish force, after several days of desultory fighting, lasting from the twenty-ninth of October to the second of November, withdrew for a last stand behind the lines of Chataldja.

Efforts for Peace

This seemed to France the proper moment for European intervention, on the basis of recognizing the political changes wrought by the war, and guaranteeing the Turkish sovereignty in Constantinople with a small bordering territory to the westward. The Powers could not agree. Before December first, the Servians had defied Austria-Hungary and occupied Durazzo on the Adriatic. The Greeks justly claimed to have 
captured Salonica, although a vanguard of Bulgarians insisted on being admitted as part of the garrison. The Chataldja lines held firm. All parties by this time began to feel the strain, and on December third, an armistice was signed as between Turkey on the one side, Bulgaria, Servia, and Montenegro on the other, Greece refusing its signature because as yet Janina, invested by its forces, had not fallen, nor had the Greek fleet been able to occupy the islands of the Egean. A Peace Conference composed of representatives of all the belligerents met at London on December thirteenth. The proposals of the Allies and the counter proposals of the Turks exhibited so wide a difference of feeling that the ensuing debates were utterly aside from the mark and almost absurd. Nevertheless, when on New Year's Day, I9I3, the Turkish delegates presented what they called an irreducible minimum, their terms still seemed to the Allies quite as impossible as before, suggesting as they did a virtual dissolution of the alliance and offering inadequate concessions of territory. In fact, Turkey appeared to the Western world rather like an Oriental merchant haggling in a bazaar than like a serious negotiator.

Should the new Ottoman empire still retain Adrianople, which the Turks regarded as their Holy City Progress of Negotiations and the Bulgarians as an indispensable frontier fortress? Could Turkey be permitted to retain the Greek islands of Imbros, Tenedos, and Lemnos because she held them essential to the protection of the Dardanelles, and others such as Mitylene because she thought them a part of Asiatic Turkey? Apparently, too, the Balkan Allies had agreed to "partition" A1bania among themselves. Austria-Hungary with the 
moral support of Italy imperatively demanded that the doubtful boundaries of that land should be settled and that some kind of autonomy should be given in recognition of its inchoate nationality. How should the European usurers who had loaned money to the Ottoman empire on the security of its former possessions apportion to the enlarged Balkan States the respective shares of the obligations they should assume? Finally, what was to become of the railway lines, nominally belonging to the Turkish government, in reality to Austro-Hungarian companies, who held their obligations? In view of the very delicate nature of the Balkan alliance, these questions were really of appalling importance, a fact well understood by the Turkish delegates in the Peace Conference. The sequel proved how shrewd and unscrupulous they were in the use of these centrifugal forces. Throughout the month of January they practiced dilatory tactics, and the war went on. Turkish forces repulsed all the attacks upon the Chataldja lines, upon the fortresses of Adrianople, Janina, and Scutari. Public opinion in Constantinople became defiant. The ministry of Kiamil, aware that the Balkan Allies were exhausting their resources, struggled to allay the rising war spirit.

Rumania scouts the idea that she is a Balkan State, holding herself vastly superior in all respects to her Slav neighbors on both sides. She had long demanded what she called the rectification of her Bulgarian frontier. In other words, her military preparations being now complete, she was awaiting a propitious moment to demand from Bulgaria both Silistria, as an indispensable frontier fortress, and Varna, as a desirable harbor on the Euxine. What was the extent of her land greed did not actually appear. Simultaneously 
with the sessions of the peace negotiators in London were held meetings of the ambassadors to Great Britain from the great powers. During their conferences, Austria-Hungary, as the frontier state of civilized Europe, made very insistent demands. Servia should have no harbor on the Adriatic. The war cry of the Allies was "The Balkan peninsula for the Balkan peoples." Very well ; the Albanians are a Balkan people; why should they be put under Slav dominion if Slavs were to be freed from that of the Turks? Accordingly, the principle, at least, of Albanian autonomy and Albanian nationality was admitted, with the single modification that in some way Servia should receive on the Adriatic a free harbor and unrestrained use of a railway connection with it.

Naturally, all these dilatory and contradictory recommendations let loose a flood of discussion. Feeling rose so high in the Balkan States, and, indeed, throughout Europe, that finally the ambassadors in London proposed that the corresponding ambassadors at Constantinople should bring pressure to bear upon the Porte for the conclusion of peace. In pursuance of this recommendation, a collective note was written and presented on January I7, I9I3, advising the cession of Adrianople to the Allies and the reference to the Powers of what would be the ultimate disposition of the Egean Islands. With proper caution the ministry summoned the Grand Council of the Ottoman empire, and on January twenty-second that august body accepted the "advice" so imperiously given. Young Turkey was furious, and the very next morning Enver Bey, who had successfully engineered the latest revolution, who had covered himself with glory in Tripolis, and was the darling of the Young Turks, 
headed a mob and demanded the resignation of Kiamil and his colleagues. A new ministry was formed with Mahmud Shefket Pasha as Grand Vizier. To this ministry a week was granted for formulating a reply to the collective note. Meantime, all the belligerents had been resting on their arms during a very uneasy armistice. The new Turkish ministry could come to no agreement, and on January 29 the peace representatives of the Balkan States at London denounced the armistice and ordered the resumption of hostilities on February 3. This action produced immediate results. On the first of February the Grand Vizier replied to the collective note that Turkey would accede to the proposition about the Ægean Islands, but demanded that the portion of Adrianople on the left bank of the Maritza River, containing the Turkish sanctuaries and a Turkish population, should remain Turkish. Two days later the representatives of Great Britain and Germany at Sophia, the latter in rather peremptory language, urged upon the Bulgarian government the acceptance of this offer. To this they replied that the Turkish communication was only another subterfuge in the long game of procrastination, which had already lasted two months, and that very evening the bombard-

Second Stage of the War ment of Adrianople was renewed.

This marked the second stage of the war between Turkey and the Balkan Allies. From the military point of view it was quite different from the first. The chief strength of both parties was concentrated on either side of the Chataldja lines. There the opposing forces remained, jealously observing one the other, manifestly in a state of considerable exhaustion. For tactical reasons the Bulgarians retreated a short distance from their previous position. To the chief com- 
manders of both hostile forces a direct frontal attack seemed impossible, and what movements there were tended toward the execution, if opportunity should present, of flank movements, the Allies with a view to advancing toward Constantinople, the Turks toward Adrianople. Persistent and continuous efforts were made by Turkey to land fresh forces in the harbor cities along the coasts of the Black Sea and on the shores of the Sea of Marmora; the almost microscopic navy of Bulgaria and the larger, better-equipped, and more efficient sea power of Greece rendered these efforts completely futile. The Turks could neither surround the Bulgarians nor did the Bulgarians succeed in occupying the peninsula of Gallipoli.

About all these movements there was an air of lassitude, characteristic of exhaustion. The siege operations, however, were energetic in the highest degree, and after a superb and heroic resistance Adrianople fell on the twenty-sixth of March. Two weeks earlier Janina, beset by the Greeks after a series of minor victories in Epirus, had opened its gates to the conquerors. The surviving fragments of Turkish military power in the west surrendered on the Lake of Ochrida, although they were much diminished in number by the withdrawal of many bands under Djavid into Albania. Scutari had displayed powers of resistance which almost paralyzed the Servian and Montenegrin forces for a time; but the gallant garrison, threatened with starvation, finally marched out with all the honors of war. Whether or not the surrender was entirely in good faith is a mooted question. Many believed there was a secret bargain with certain leaders among the besieged. King Nicholas entered and celebrated the Greek Easter festival within the fortifications amid the 
ruins of the town, but his tenure of the place which he announced to be the future capital of Montenegro and his exultation were of short duration. The Allies were now in possession of all Turkey in Europe west of the Chataldja lines, but the insistence of Austria that some kind of national existence should be secured for Albania, rendered imperative an international occupation of Scutari, and it was a crestfallen monarch who, as gracefully as he might, handed over the fruits of his hard-earned victory to a composite force of marines under the command of a British admiral. As we have indicated, the movements of the Balkan fleets were of considerable importance, but they were not marked by any tactical regularity, and had absolutely no connection with the military movements by land.

Partial and Temporary Peace

All Europe had lived throughout these portions of the war in a state of nervous uneasiness lest the Western powers should be drawn to a greater or less degree into hostile relations with each other. Indeed, at one juncture, both Russia and Austria-Hungary mobilized a considerable portion of their respective armies, but their reciprocal fears were allayed by the dispositions of the ambassadorial conferences in London, and by the acquiescence of the Balkan plenipotentiaries at the same capital in a peace which fixed the western boundary of Turkey in Europe by a line extending more or less irregularly from Enos, a village on the Egean, to Midia, a town on the Black Sea. In this temporary peace the question of the Ægean Islands, alike those which command the entrance to the Dardanelles and those so close to the shores of Asia Minor that they virtually dominate it strategically, was left unsettled. It was understood that the Balkan States had already 
agreed as to the division among themselves of all the Ottoman possessions in Europe. This was true, had the Albanian question not been opened as it was. If there were to be a semiautonomous Albania, all previous calculations were overthrown, and the apple of discord was flung into the very midst of an alliance formed with difficulty, marked by mutual suspicion, and existing under the most favorable circumstances in unstable equilibrium.

Accordingly, on the conclusion of this so-called peace, marking the end of the second stage of the war, not one of the Balkan powers began to disarm. Quite Discord Among the Allies the contrary; they put forth spasmodic, and in some cases efficient, efforts to increase their military power. Were Bulgaria to retain all the lands marked by her for annexation before the outbreak of the war, she would have a territorial aggrandizement completely oversetting the Balkan balance of power; while, if Albania were to be withdrawn from the respective shares of Greece, Montenegro, and Servia, their expectations of enlargement would be bitterly disappointed, at least as to degree. Whether wittingly or not, Bulgaria left upon an observant world an impression of dictatorial arrogance. It was she who had furnished for the conflict, as her people firmly believed, the most efficient army, had borne the fiercest brunt of battle, and who ought therefore to secure the largest share in the booty. Suddenly Rumania unmasked her plans. She appeared to herself and others in the light of a Balkan arbitrator. With a shrewd though selfish policy, and managed by a wise, experienced band of statesmen, headed by a trusted sovereign, she was also backed by a superb army. It was perfectly clear that she would not permit the readjustment of frontiers so as to leave 
herself without such compensations as to insure at least her equality in the Balkan balance of power. The tension after the so-called peace was like that of a live electric wire, and it could only be a question whether in the third stage of Balkan struggles the larger Europe could again refrain from intervention and leave the ultimate decision in the hands of the weary but not discouraged combatants.

On the nineteenth of April the armistice of Bulair had been signed by Bulgaria, Greece, and Servia. Scutari had fallen into the hands of Montenegro on the twenty-third; the truce had then become general and thereupon hostilities between Turkey and the Balkan allies came to an end, at least for the time being. It has already been explained that for her own particular reasons Austria-Hungary made the creation of an autonomous Albania a basic condition of the ultimate settlement. Throughout Russia the fall of Scutari had created an almost universal enthusiasm, while, on the other hand, the powers of Western and Central Europe demanded, and secured, almost instantly, the evacuation of the town by the Montenegrins. On the fourteenth of May representatives of the Six Powers took possession of the place on behalf of the inchoate principality of Albania. Thus, and thus only, was it possible to prevent the outbreak of hostilities between Russia and Austria-Hungary. Shortly after, delegates from the states engaged in the war met at London and opened a second conference. Under the pressure of the Six Great Powers, exercised in a cogent warning by Sir Edward Grey, an agreement was reached and a treaty signed on the thirtieth of that month. Turkey was to surrender Crete and all the continental land west of the Enos-Midia line. The delimitation of Al- 
bania and the question of the Agean Islands were to be the affair of the Powers, and financial questions were to be adjusted by an international commission, which would be summoned in due time to meet at Paris.

Immediately thereafter, however, the question of how to apportion the surrendered territories among the victors became acute. Bulgaria was persistent in claiming most of Macedonia, including Salonica and Monastir; Servia clamored for that greater share of Macedonia which the Serbo-Bulgarian treaty of March 13, I912, had allotted to her; Greece avowed her right to both Salonica and Kavala on the basis of conquest; Rumania demanded from Bulgaria, as compensation for her neutrality, a cession of important territories in order to secure her share of the booty and a strategic frontier. So alarming was the state of public opinion in each of these states that the Czar proposed to mediate. He met with a chilling repulse, and Bulgaria, encouraged, as is generally believed, by Austro-Hungarian influence, gradually renewed hostilities not only with her one-time allies but with Turkey and Rumania as well. There were conflicts with the Greeks in the neighborhood of Panghaion and a three days' battle at Slatovo with the Servians. This was on the thirtieth of June. Five days later diplomatic relations with Greece and Servia were suspended, and Montenegro declared war against Bulgaria. Her example was followed by Rumania on the tenth, and, as if by prearrangement, the Turks advanced on Adrianople, reoccupying it on the twenty-second of July.

To the Rumanian invasion no resistance was made, but against the advance of the Greeks there was a show of orderly warfare. The Greek armies could not be checked, and, while those of Rumania were advanc- 
ing toward Sophia from the north, those of Greece were coming up the Struma River toward the same goal. The Servian armies were likewise successful in their movements, and were menacing the Bulgarian town of Kustendil, whence they, too, threatened to move upon Sophia. Surrounded on all sides by successful invaders, Bulgaria expressed the desire to treat for peace. Unable to enforce any claims whatsoever, with an army utterly exhausted, and compassed about by victorious enemies embittered more than ever before, she assented to the terms laid down at Bucharest by the representatives of her foes and emerged from the long struggle not only shorn of her military prestige but with territorial gains almost contemptible. The frontier demanded by Rumania was granted; to Servia were ceded Kotchana and Radovisht ; to Greece, Salonica, Doiran, Demir-Hissar, Seres, Drama, and Kavala. From all her exorbitant claims in Macedonia she secured only the town of Strumnitza and those districts of the Ægean shore between the rivers Mesta and Maritza. The line between Servia and Greece was so drawn that Monastir fell to the former, Vodena and Florina to the latter. Montenegro received from Servia about one half of the Sanjak of Novi-Bazar.

It is fairly claimed by the dismayed opponents of armed peace that the recent enormous expenditure imposed by Germany upon herself in order to raise the peace footing of her army to 900,000 men, an expenditure of $\$ 300,000,000$ in our money, which will result in an increase of the annual budget by $\$ 45,000,000$, is altogether due to the rise of Slavic power in Eastern Europe. Since her humiliation by Japan, Russia has virtually doubled her military strength, and now the south Slavs have become a force of the first 
importance. Simultaneously, France has reestablished the three years' period of compulsory military service and expended $\$ 200,000,000$ on her army and navy. Austria-Hungary demands $\$ 240,000,000$ to make her military force by land and sea more efficient; as well as a permanent increase in her annual budget, in order that she may enlarge her standing army by 80,000 men. About these figures there is absolute certitude. Italy is occupied with similar designs, while Great Britain, followed by Spain and the lesser powers, has caught the infection.

In the panic on the Berlin Exchange, brought on by the declaration of hostilities in the Balkans, there was a shrinkage in values of $\$ 1,000,000,000$, and the other money centers of Europe were similarly affected. The financial disturbances of recent years began when Austria-Hungary announced the annexation of Bosnia and the Herzegovina. Instantly, Bulgaria asserted her claims and displayed a like contempt for the Treaty of Berlin, for thirty years the public law of Europe. A little later Italy seized Tripoli, and the climax of the whole disorder was the Balkan War of I9r3. The results are not edifying and probably insecure. Bul-

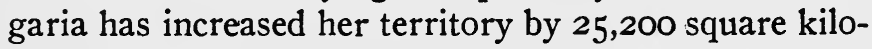
meters and nearly one half a million inhabitants, Servia by 35,500 square kilometers and $I, 290,000$ inhabitants ; Greece by 56,000 square kilometers and $1,900,000$ inhabitants. On the other side of the balance sheet are these mournful facts: Servia lost 71,000, dead and wounded; Montenegro, I I,200; Greece, 68,000; Bulgaria, I56,000; Turkey, I50,000. These appalling losses were of soldiers in the ranks. It is not possible, even approximately, to estimate those who died from outrage, massacre, and disease. For military purposes, 
the maintenance and mobilization of armies, and the distribution of war materials, these countries expended about one and a half billion dollars. The economic disaster consequent upon losses in commerce, manufactures, and agriculture cannot possibly be represented in figures.

These wars, as we have explained, were ostensibly, and we are fain to believe, in a measure, really undertaken to emancipate from the horrors of Turkish misgovernment the kinsfolk of the various nationalities. Beyond any peradventure they turned almost immediately into a freebooting expedition to despoil Turkey; their close was marked by the most shocking exhibitions of greed and violence in the distribution of the spoils. $^{1}$

Furthermore, the final terms of settlement, as laid down in the treaty of Bucharest on August Io, paid little regard to the "nationalities" of the inhabitants living on the various lands apportioned to the combatants. A glance at a good ethnographic map will show that Rumania, by the extension of her southeastern frontier, acquired many new subjects, a majority of whom were Turks; that Bulgaria under compulsion abandoned great numbers of those whom she had loudly declared to be her kinsfolk in Kotchana and Radovisht to Servia on the one side, and on the other to Greece a great slice of Macedonia, including Salonica and Kavala, which presumably swarmed with so-called Bulgarians. The Greeks had to be content when their kinspeople in Monastir were assigned to Servia, while Servia granted to Montenegro, as has

${ }^{2}$ A Few Lessons Taught by the Balkan War, by Alfred H. Friend, published in the International Conciliation Series. 
been told, about one half of the coveted Sanjak of Novi-Bazar with its Servian population.

By the treaty of Constantinople the line between Turkey and Bulgaria, the two contracting powers, was arranged partly with reference to the mandate of the great powers concerning the Enos-Midia line, but by substantial deviations at both ends and in such a way. as to keep Adrianople under Turkish rule. Bulgaria could not even secure control of the railway connections with the one new port on the Egean which she had acquired, and incurred serious losses in establishing her authority over the portion of Thrace allotted to her.

There is a sense in which the new Albania may be considered almost a joke. A recent traveler in Epirus declares the Albanian nation to be a myth. Its inhabitants roundly and persistently declare themselves to be Greeks. Even the Mussulmans of that land permit no one to call them Albanians, asserting their undiluted Hellenic character. The next generation of their descendants, it is declared, await only a sufficient inducement on the part of the Greek government to become orthodox Greek Christians, as their remote ancestors were. The international commissions have been steadily at work determining the frontiers and announce their work as completed, but the guerilla warfare directed against the Servians did not until within a doubtful recent limit stop for a moment, if, indeed, it ever will, and there is probably no greater hotbed of Hellenism than Koritza, which has been assigned to Albania. When, finally, the frontiers shall have been not only definitely surveyed, but accepted, it will take years of constant, watchful intervention on the part of the Western powers to 
maintain anything like order, and the moral effect of trampling under foot the whole doctrine of nationality, for which war was ostensibly waged, will be deplorable. The Hoti and Gruda tribes of the north have refused to acknowledge Montenegrin sovereignty, and the town of Tuzi has been seized and occupied by the Malissores. When Servia finally crossed the northern border and captured a chieftain of the Albanian marauders, Austria-Hungary presented an ultimatum at Belgrade demanding the prompt withdrawal of Servian troops behind their own frontier and Servia acquiesced. For a time there was a provisional "republic," styling itself a government, at Avlona, and a native Albanian "king" reigning at Durazzo, while a British admiral governed Scutari. An attempt in January of this year (1914) to create a throne for a Turkish prince was thwarted by the joint military action of the great powers and the vigilance of Italy. The International Commission of Control has its seat at Avlona. There are six members, representing the Six Great Powers, which by correspondence have finally agreed upon Prince William Frederick of Wied, a German Protestant and a nephew of Queen Elizabeth of Rumania, as the first ruler of the autonomous Albania, yet to be. His subjects will comprise not only Mussulmans but Catholic Christians, both Greek and Roman. How these three antagonistic elements can endure the sway of a Protestant remains to be seen. He himself regards the dignity of such a throne without enthusiasm. The task, however, appeals to his sense of duty. He enters upon it with a full comprehension of the problem, and has displayed great firmness in securing an auspicious beginning. 


\section{VII}

\section{THE FORMATION OF THE BALKAN ALLIANCE}





\section{VII}

THE FORMATION OF THE BALKAN ALLIANCE ${ }^{1}$

THE states of the Balkan peninsula are, as we have probably made clear in the preceding chapters, still in The Principle the condition of political apprentices. Certain of the prominent principles of European politics they have grasped with a firmness which amounts in many cases to foolish obstinacy. For example, they have a fanatical regard for what they call "the principle of nationality," a principle not well understood even in Western Europe, and by them based upon preposterous assumptions. They likewise know only too well the whole sad story of the Balance-of-Power doctrine in Western Europe, and its corollary, the idea of Compensation; of Constitutions they are continuously prating in a way which makes perfectly clear that the alphabet of constitutional government has not yet been learned by them. In preceding chapters, the difficulties which lie athwart the formation of a permanent Balkan alliance have presented themselves in every connection.

In one of his admirable political studies, James $\mid$ Bryce, after a comprehensive examination, made apparently upon the spot, of the Balkan peoples, suggested that there was but one possible solution of the problem as to how Turkish tyranny and oppression were to be ended definitely in Europe. He spoke of a federation including all the then independent and semi-

${ }^{1}$ Compare a series of articles in the London Times published between June 6 and $16,1913$. 
independent young states, which could both throw off the Turkish yoke and if cemented by reciprocal good will could best solve the problem of Constantinople. We propose to outline as accurately as the information obtainable will permit how the temporary federation for this purpose was secured.

After the Russo-Turkish war of 1877 , and the adoption of those principles for international control known as the Treaty of Berlin, suggestions of alliance secured some slight attention even in the Balkan States. The Treaty of Berlin utterly ignored the so-called principle of nationality. At the time, and since, the leaders in each of those states sought diligently some basis for lines of national demarcation. In the case of Rumania, as we have seen, it was not difficult to find them, and, in a way, the Greek nation was likewise discernible; but when it came to distinguishing Servians from Croats, to determining exactly what the Bulgarian was and where he dwelled; when, further, it came to settling the question of how Rumanians and Kutzovlachs who did not live within the kingdom of Rumania were to be treated by the other race elements, there appeared powerful and uncontrollable centrifugal forces.

Futile Efforts

Toward Alliance

Servia has not produced many statesmen. One of the few, Ristitch, suggested that a reformed and constitutional Turkey might cooperate with Bulgaria, Greece, and Servia in a confederation for the improvement of conditions which had become intolerable. King Charles of Rumania and Prince Alexander of Bulgaria expressed some interest in such a project. When, however, Eastern Rumelic, rose in revolt in 1885 and was substantially incorporated in a Bulgaria quite different in dimensions from that contemplated by the 
Treaty of Berlin, neither Servia nor Greece would any longer entertain the idea. Bulgaria, thus aggrandized, was already a menace to the balance of power in the Balkans, and both these states demanded compensation. As we have seen, Milan, the king of Servia, supported by Austria-Hungary, actually went to war with Bulgaria, but suffered a humiliating defeat at its hands. The powers of Western Europe joined in a naval demonstration against Greece in order to quench her ambitions, and Russia, by means of her secret agents at Sophia, brought about the fall of Prince Alexander. Thereafter, for a considerable time, the situation was exactly reversed as regarded the exercise of Russian influence in the Balkans. Stambuloff, the Bulgarian prime minister, resisted the Czar's influence successfully, while Servia became his creature. The feeling between these two states was therefore even more embittered than hitherto. Austria-Hungary gave at least her moral support to Ferdinand, the new prince of Bulgaria. It seemed as if the idea of a Balkan alliance could be nothing more than a dream.

In I89I, however, Tricoupis, the well-known Greek statesman, paid a personal visit to both Belgrade and Sophia in the hope of reviving the idea and securing military support for a campaign against Turkey. Naturally, the question of dividing what remained of Turkey in Europe among the three was uppermost in the minds of all. With characteristic insight, he had convinced himself that, in the case of an attack upon the Ottoman power, the Western nations would not interfere. He must likewise have had a secret understanding of Rumania's policy of isolation, for he did not visit Bucharest. At both Belgrade and Sophia he thoroughly discussed the principle of mutual concession 
Twenty

Years of

Diplomacy when the time should be ripe for the partition of the Turkish possessions. This principle, however, remained and is likely always to remain very hazy in the minds of all who are influential in the conduct of Balkan affairs. At that time there was a complication of circumstances which perhaps justified the exaggerated and blustering patriotism of all four governments. Ferdinand felt that for the consolidation of his power any adventurous policy would be very dangerous. At any rate, the facts came to the knowledge of the Porte and were by it made sufficiently public to prevent any further agitation of the plan.

For twenty years the scheme of a Balkan federation remained in abeyance. The shrewdest observers expressed the opinion that such an alliance was impossible. The guerilla bands of Greece, Servia, and Bulgaria ravaged Macedonia throughout all its borders. Mutual envy and spite were kept at fever heat by the perpetual agitations for securing money and men for this nefarious warfare in all three of the states. There was no sense, no reason in the procedure; merely a wild, vague conception that when the inevitable climax should come, the partition would be made on the principle that the more national bandits the greater the national share of the booty.

Throughout this period of twenty years, diplomacy was degraded almost to the level of conspiracy. Mention has been made of the "Great Ideas" entertained by the respective nations of Eastern Europe. Among these, as has been said, that of Russia is her succession to the influence and power of Byzantium as the allinclusive Greek empire. Austria-Hungary, on the other hand, has had a history so extraordinary that her chief aim is to prevent what may be called Greek and Slavic 
aggression upon the eastern frontier of the Hapsburg lands. Her general policy, therefore, has been to create dissensions among the various Slavic stocks, to embitter their relations one with the other, and to prevent whatever strength there might be in union. Any combination, however temporary or preposterous, which is hostile to Russian pretenses, is sure to find powerful support with the authorities at Vienna and Buda-Pesth. Accordingly, this period of outward peace was really one of fierce diplomatic warfare. While the inner history of the time has been carefully concealed, yet there seems no doubt that, when in 1897 Greece entered upon a period of foolish warfare with Turkey, Russia and Austria-Hungary combined to prevent Servia and Bulgaria from joining in the hostilities. The most recent events seem to prove that Rumania had some secret understanding, probably with Servia, whereby she was, if necessary, to attack Bulgaria and secure in compensation a considerable portion of Eastern Rumelia. Whatever the reasons, Bulgaria rejected overtures from Greece for a portion of Macedonia with a harbor on the Egean. Russia and Austria-Hungary were harmonious for the moment in preventing Bulgaria from joining the federation, and in keeping active the Bulgarian policy of friendship with Turkey. Utterly futile was the effort, the origin of which is not clear, to secure in I90r some arrangement between Greece and Rumania. King Charles and the late King George were for some time visitors together at an Austrian watering place on the Adriatic. A body of Rumanian students organized a tour to Athens, where they were warmly welcomed. It is inconceivable that there should have been any serious statesmanship concerned in such a movement. 
Balkan Jealousy and Strife
Turkey

Prepares the Way
The effort for reform in Macedonian conditions under a combined Austro-Russian control was equally futile. The emissaries of Abdul Hamid ranged the province and intensified the conflict of races and creeds. The Greek komitadjis, or bandits, became more and more numerous. Their special aim was to complete the process, begun in I903, of "converting" the Vlach settlements, and in the autumn of 1905 the diplomatic relations between Greece and Rumania came to an end. Bulgaria began to persecute the Greeks within her borders, and, in short, Macedonia was turned into a hell on earth. In I905 there was talk of a customs union between Servia and Bulgaria, but it remained empty talk. As late as I9II, therefore, intelligent visitors to that distracted portion of Eastern Europe could see no light in the darkness. The rivalries of Russia and Austria-Hungary, the contemptuous tyranny of Turkey, the half-barbarous tribal conflicts, the barbaric rage shown by the Balkan powers to each other-these created a situation which was the despair alike of wild and of civilized Europe.

Curiously enough, it was out of darkest Turkey that the partial solution of the problem came. The Young Turk Revolution was based upon a chimera, but a most glittering and attractive one. Promising liberty, justice, and equality for all, it would, if successful, regenerate Turkey in Europe, make possible the long-since abandoned conception of a peaceful federation between the Balkan States, with Turkey as one of its important members, and produce, at all events, a period for recuperation and reflection. In all the extraordinary story of Turkish rule over Christian peoples there is no series of events so enlightening, from an historical point of view, as those 
which constituted the so-called Young Turk Revolution. It was the effort of the vanishing race and religion to assume the garb of Western constitutional government and thereby retain, for a time at least, its ascendancy over the Christian subject races, to ward off for a period the menace of European intervention, and to abolish the capitulations which had hitherto secured some degree of tolerance to Christian nationalities within the Ottoman empire.

The Young Turk movement, it must be remembered, was essentially military in its character. Based solely and entirely on military power, it was an alliance of so-called statesmen with an ignorant soldiery, in reality of scheming politicians with a uniformed, fanatical Moslem peasantry. Nevertheless, in the glamor of its earliest stages, the more enlightened sentiment of the Balkan powers began to assert itself. In I908 Bulgaria had proclaimed her absolute independence and thereby put a considerable strain upon her relations with jealous neighbors; but when Austria-Hungary formally proclaimed to the world her annexation of Bosnia and the Herzegovina, the two purely Slavic states of the peninsula, Servia and Montenegro, began to tremble for their very existence, and relations which had been rendered hostile almost to the point of rupture, partly by the dynastic scandals at Belgrade and partly by the machinations of radicals in Cettigne, were slowly renewed in the face of the common foe. Both these states mobilized their armies and agreed on the terms of a military convention. The apparent ease with which two governments, so long posing as deadly foes, laid aside their animosity and combined for self-preservation may fairly be regarded as a sign of the times. 
The next strange and unexpected political phenomenon occurred in I910, when the Albanians, keenly alive to the success of other populations round about, began to assert their nationality, and thereby threatened the further disintegration of Turkey. Young Turkey regarded the movement with great uneasiness. Hitherto the devout Albanian Moslems had been an impregnable barrier against Slav aggression from the north. The movement for nationality in Albania was a menace to the very existence of Turkey in Europe, and the revolt was accordingly suppressed without pity or mercy wherever Turkish troops could march. But into the mountain fastnesses occupied by the two wildest clans, those known as the Mirdites and Mallissores, troops could not penetrate in regular military formation. Those wild tribes, moreover, were Christians and members of the Roman Church. Along the frontier line between them and Montenegro they made a brave stand for what they called their liberties, but in a comparatively short time their scanty resources were exhausted, and they threw themselves upon the mercy of little Montenegro, a land of Slavs who professed Christianity of the Greek form. What was perhaps still more amazing, these fanatical Greek Christians received the equally fanatical Roman Christians with kindness, afforded them protection, and, at great cost, supplied them with the necessities of life.

The Young Turks were naturally dismayed, but in Albania proper they had nevertheless outwardly restored peace. It was a peace like that described by Tacitus - the peace of a desert. The population was disarmed, and the new Sultan made a royal progress, stimulating the religious zeal of the people, as he and 
his followers vainly supposed, by the pompous ceremonies known as the selamlik. Entirely content with their success in pacifying Albania, the Young Turks resolved upon a similar treatment of Macedonia. The public has been very well informed as to what happened in Albania, but there has been a conspiracy of silence on the part of the great powers as regards the events of that terrible period in Macedonia. As yet, not one of the consular reports has been published by any government of Western Europe, and, what is still more extraordinary, the entire European press has seemed to combine to prevent the publication of any letters from its correspondents. Whatever the facts, the result was that the Christian races of Macedonia began to act in harmony. They forced their prelates of high and low degree, those professing allegiance to the Greek patriarch, as well as to the Exarch of Bulgaria, into a kind of political leadership. Another miracle had been wrought, and even amid the Greek peasants of southern Macedonia, there was formed the conviction that the cause of Bulgarians and Servians within the possessions of Turkey in Europe was really their own. King Nicholas of Montenegro had invited King Ferdinand of Bulgaria, and the crown princes of Servia and Greece as well, to celebrate his jubilee with him at Cettigne, and they came-which was another proof that public opinion throughout the Balkan States was at least embryonic and liable to develop. Very shortly afterward it leaked out that should Turkey and Bulgaria renew hostilities, the army of Rumania would cooperate with that of Turkey. What would happen in other parts of the Balkans should Bulgaria be defeated by a combination of Young Turkey and Rumania? As the best authority (Bouchier) has de- 
A Common Suffering Unites the Balkans

clared, this was the moment when the instinct of selfpreservation was awakened.

The revolution at Constantinople, therefore, was indirectly the cause of the truce between the Christian nationalities, especially those of Bulgaria and Greece, which seemed to give promise of a gradual reconciliation. Since the opening of this century the condition of Macedonia could only be likened to that of a primitive giant, lacerated and bound, at times seemingly in its death throes, yet recuperating its strength in every short interval of hostile lassitude. In 1903 the state of affairs appeared so bad that it could not be worse. In I9I0, after the revolution of 1908 had ended the administration of Hamidian Turkey, matters were at least as bad, if not worse, but this time it was due to the grim determination of the Young Turk administrators to obliterate all feeling of nationality in its population and enforce the doctrine of Turkish citizenship without regard to race or religion, and to the ruthlessness with which all resistance was overwhelmed. Diverse as are the race elements in Macedonia, yet famine and rapine have been, to a certain extent, elements in the amalgamation. To preserve their children alive, and their families from violation, even the village leaders were disposed in their extreme discouragement to submission. It is said that Abdul Hamid, hearing in his enforced retirement of the conditions, chuckled vindictively and prophesied the ultimate destruction of Young Turkey, when Greeks and Bulgarians should be even partially reconciled. It was the climax of their common sufferings which brought about just that degree of reconciliation which was necessary to ruin Young Turkey. 
In consequence of their arrangement with Rumania, the Young Turks began in the early winter of I9rorgI I to assemble along the Greek and Bulgarian frontiers masses of soldiers brought from Asia Minor. This appears to have been in part merely a threat to prevent Bulgaria from urging further the junction of the Bulgarian and Macedonian railway systems. Bulgaria and Greece had alike prolonged their railways to their respective frontiers, but Turkey, controlling the connection with Central Europe, had stubbornly refused any connection of these railway lines with its own. To this hour Athens has no railway connection with Europe. The junction will, of course, be made at the earliest possible moment; work has already begun. Simultaneously, the question of Crete, whose inhabitants were determined upon annexation with the kingdom of the Hellenes, had become acute. Turkey, trusting in the European concert to prevent the further disintegration of her territory, inaugurated an almost complete boycott of Greek commerce in Salonica, and the Greeks, within or without the kingdom, felt the sting, alike of their humiliation and their money losses, to such a degree that the powerful organization known as the Military League began to revolt against the pacific policy of the Greek government.

The unquestioned leadership of Hellenic agitation in Crete was in the hands of Venezelos. This remarkable man was persuaded by the discontented at Athens to come thither for consultation. Within a few months he had so impressed both King George and the political leaders in Greece with his good judgment and his administrative power that a general agreement was reached whereby Turkey was, at least temporarily, to 
be conciliated, in order that the Greek army might be reorganized and the navy refitted antecedent to any offensive movement. Venezelos undertook to form a new government, and became the foremost Greek of his time. Almost simultaneously Gueshoff, a commanding figure in Bulgarian affairs, had advocated, in a powerful and widely read speech, a similar policy for Bulgaria. King Ferdinand and his people felt the force of the reasoning, and he was called to form a government which would carry out his plan.

Rumanian policy has, of course, been chiefly determined by the fact that its border is Russia. For the same reason there has always been more or less mystery about her attitude in the politics of Eastern Europe. During the negotiations with Turkey, Bratiano had been prime minister at Bucharest, the exponent of vigorous military measures to secure for his country compensation offsetting the enlargement of Bulgaria's borders. Naturally, his vigorous foreign policy had reacted, and not in a conciliatory way, upon the internal politics of the kingdom, and in January, I9I I, being unable to control his government any longer, he resigned. For the moment Rumania was eliminated from the question to be considered by Bulgaria, Greece, and Servia. Venezelos and Gueshoff were just proceeding to make overtures at Constantinople when suddenly their plans were completely thwarted by a violent agitation in the Turkish press, which regarded the appointment of a Cretan rebel as Greek premier in the light of an insult to Turkey. In consequence, the entire Greek boycott became more harassing. The murders of Christian leaders in Macedonia increased in number, and all pretense of treating Macedonia with moderation was abandoned. 
Already, in 1910, the Austro-Hungarian Minister for Foreign Affairs had warned the Young Turks of the imminent danger, and had made perfectly clear to the Grand Vizier that their policies would inevitably produce a Balkan alliance: it was, indeed, at the very moment when the Turkish newspapers were breathing fire and slaughter that he expostulated with the Young Turk government in terms which could not be disregarded. Deferentially and hypocritically, the government pretended to woo the Greek patriarch and publicly announced an inchoate understanding; but the deeds of their agents in the harbor cities and in Macedonia continued to be quite as hostile as before. Professions therefore produced no effect upon Greek sentiment. At the two extremities of the Ottoman empire, in Yemen and the Albanian mountains, insurrection grew more determined, while the temper in Macedonia became alike more rebellious and more hopeful.

Venezelos then formally proposed to the Bulgarian government that the two powers should cooperate in the pressure exerted on the Porte, in the efforts of the Greece and Bulgaria in Concert ecclesiastical authorities at Constantinople, which were working in harmony, and in making such representations to Western Europe as would secure the assistance of the Powers. This document was presented at Sophia in April, I9II. Brief and to the point, it proposed common action for the defense of the Christians in Turkey and eventually a defensive alliance, should Turkey attack either of the two contracting parties. This step was taken with the full knowledge and approval of King George, but in such secrecy, that no outsider, not even a Greek, was aware of the fact. This secrecy was as complete at Sophia as at Athens, and it was not until after weeks, when a 
diplomatic basis for negotiation had to be established, that even members of the Greek and Bulgarian governments were informed. Bulgaria was very slow to act. King Ferdinand is a farseeing and extremely cautious ruler. Whatever Macedonian peasants claiming to be Bulgarians might feel with regard to their fellow peasants claiming to be Greeks, the authorities at Sophia were slow to accept the sincerity of official Greek professions. Moreover, the Bulgarian government had unlimited confidence in its own army and distrusted the efficiency of the Greek armaments. To be sure, Venezelos had already secured French and British instructors for the Greek forces by land and sea, but Bulgaria, trained and armed under German guidance, was disposed to be contemptuous and adopted a passive attitude. The only indication of her tendency was given when, in August, the Bulgarian Parliament, sitting at Tirnovo, amended the Constitution in a way to invest the Crown with enlarged powers of treaty-making. There was also more frequent intercourse between subjects of the two nations. Bulgarian students visited Athens and were kindly entreated; the Bulgarian Exarch, the Armenian and Chaldean patriarchs united for the first time in modern history to make a joint representation at Constantinople concerning the rights of Christian communities in Turkey.

Suggestions of Full Alliance

Into this entangled skein of affairs there entered a further element of confusion when war broke out between Italy and Turkey. King Nicholas promptly proposed immediate mobilization to all his fellow sovereigns in the Balkans. Turkey was forced to consolidate her armies on the Greek and Bulgarian frontiers, and it was not until Italy promised to re- 
spect the situation in the peninsula, that peace was momentarily assured. The effect, however, upon the Balkan States was noteworthy. While the Greco-Bulgarian proposition was apparently held in suspense, the government at Sophia made advances to that at Belgrade. This was in November, I9II, and early in I9I2, on February 2, the crown princes of all the Balkan States assembled in Sophia to celebrate the coming of age of Prince Boris, the Bulgarian heir apparent. The Bulgarian prime minister had intended that this demonstration should be understood, as it was, to be an indication of an inchoate alliance.

On May 29 the Greco-Bulgarian treaty was signed at Sophia by Gueshoff and the Greek ambassador, both declaring that the two kingdoms firmly desired GrecoBulgarian Treaty peace. The document states that this object can best be reached by a defensive alliance, by the creation of political equality among the different nationalities in Turkey, and by the careful observation of treaty rights. To this end the two nations would cooperate to promote correct relations with the Porte and to consolidate the good will already existing between Greeks and Bulgarians in Turkey.

Furthermore, the two powers agreed that if either was attacked by Turkey, they would aid each other with their entire forces, and conclude peace only by reciprocal agreement. Both states were to use their influence to the uttermost with their kindred populations in Macedonia for securing a peaceful solution of their previous animosities, and offer active reciprocal assistance in order that they might conjointly impress on Turkey and the great powers alike the importance of such representations as were made to assure the performance of treaty obligations. 
The treaty was to run for three years, and for a fourth unless denounced six months in advance, and must be kept absolutely secret between the two contracting parties. Bulgaria would not intervene in the settlement of the Cretan question, and would remain neutral should war break out between Greece and Turkey regarding the admission of Cretan delegates to the Greek parliament. To all outward appearance, this compact appeared pacific in its intentions, being not merely defensive, but containing the pledge that both states would avoid aggression or provocation and would bring pressure upon their kinsfolk within the Ottoman empire to live peacefully with each other and with their Turkish fellow subjects. Its aim appears to have been the exertion of efficient diplomatic pressure at Constantinople and in the capitals of Western Europe.

BulgariaServia Treaty
Antecedent to the signature of this document, a similar agreement had been reached between Bulgaria and Servia. It must not be forgotten that, to all Servians in Servia proper, Austria-Hungary appeared in the light of a deadly foe, a malicious viper, engaged in strangling a small but courageous enemy. I have here and there in these pages narrated personal experiences in Belgrade, where the effort to exaggerate the importance of the Servian population in Macedonia seemed ludicrous. There was one, and only one, reality underlying the Servian braggadocio. In the districts known as the Kosovo and Old Servia there were and are many of unquestioned Servian stock. The Servians in general did not impress me as a fighting people, and in those two districts Albanian robbers and bandits were permitted by Young Turkey to work their will with the Servians. Whether this was active insti- 


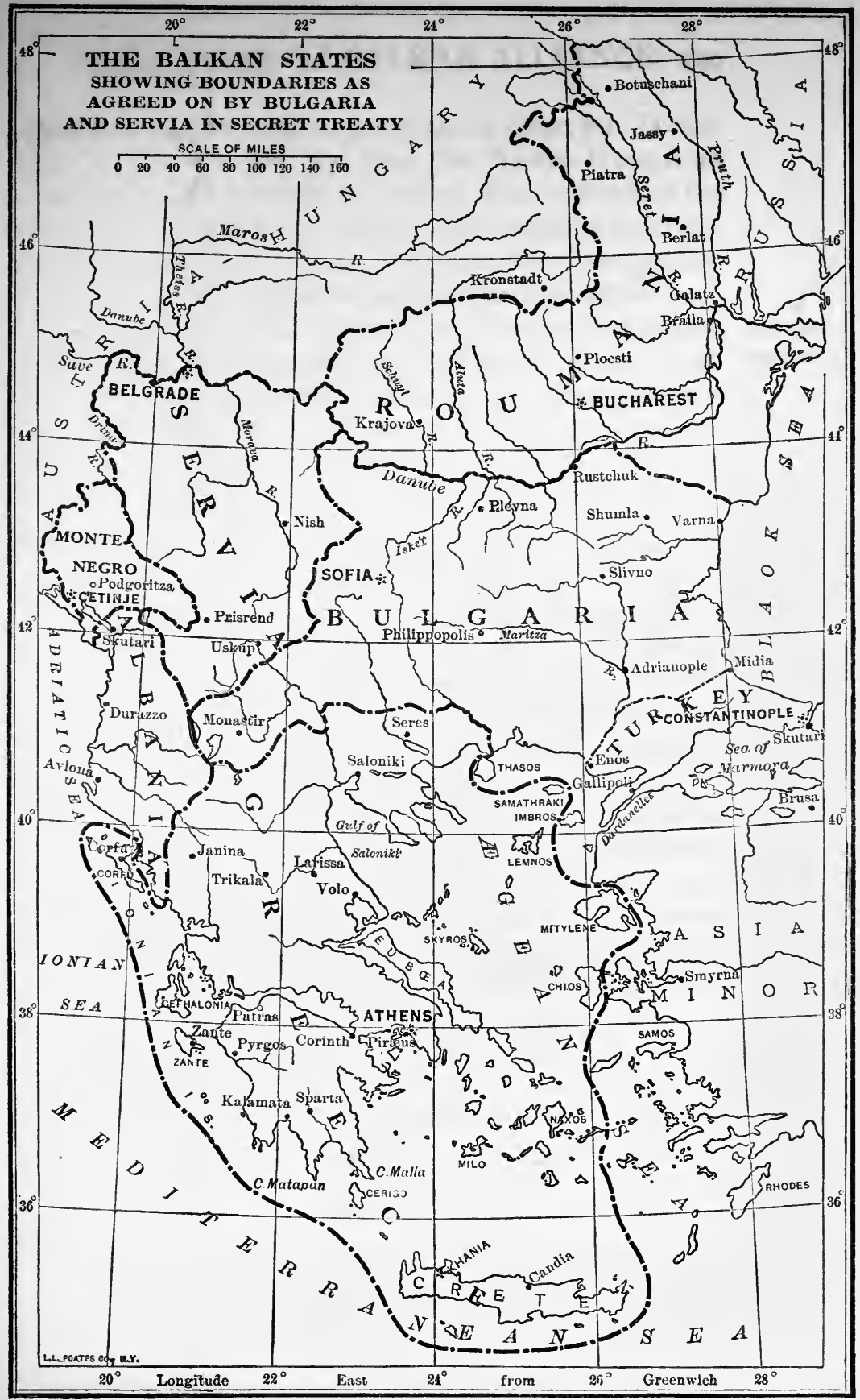

This map indicates the intended partition of Macedonia only : the author has found no trust- 
gation or passive indifference was not clear, but Turkey was a less dreaded foe than the Austro-Hungarian monarchy, and hostility to Turkey was confined in the main to an exhibition, mainly upon paper and in the school textbooks, of how important the Servian element in western Macedonia should be considered.

Among the many visions of Russian statesmen, there is that of hegemony in a Pan-Slavic world. Such Russian Influence a world must, of course, embrace both Bulgarians and Servians. Intermittently, therefore, Russian influence had long been exerted to create harmony between the two states. Servia, of course, dreading Austro-Hungarian hostility, was naturally more heartily inclined to such an understanding. For the Bulgarian patriot as for the Russian the real enemy was Turkey, and whether or no Austria-Hungary penetrated to Salonica on the Ægean was a matter of small importance compared with Turkish maladministration to the south and east of Sophia. The Bulgarian plan had been to secure autonomy for Macedonia in the expectancy of eventual annexation. To Greece particularly, and to Servia in a high degree, such a prospect was most distasteful. Both demanded their share in the respective spheres of influence of a tripartite Macedonia and sought to secure it in the guerilla warfare to which frequent reference has been made.

It was in 1902 that, in the Shipka Pass, Russia exhibited the degree of her influence among South Slavs in a series of apparently spontaneous demonstrations made by them. In the following year, 1903, the revolt of Bulgarians in western Macedonia took the form of a succession of manifestations favorable to Russian aspirations. The Czar sought to inaugurate a substantial Serbo-Bulgarian understanding, but 
the effort was thwarted by a rumor which was promulgated far and near, probably by Turkish agents, that what Russia wanted was such a readjustment as she had outlined in the treaty of San Stefano, which would have given even greater ascendancy to Bulgaria. King Peter and his advisers in Belgrade grew more and more suspicious. Large and numerous Servian bands were sent into Macedonia, where, for the most part, they cooperated with similar Greek ones. The Young Turk Revolution of 1908 brought about no real change. The Bulgarians were still regarded as the most dangerous element in Macedonia; many churches, schools, and monasteries, which they claimed, were, in one way or another, put under Servian control, and for three years Young Turkey and Servia were friendly to each other.

The principal industry of Servia is the raising of swine. It was through Turkish territory that she was able to export her wares. In 1906 the tension with Austria-Hungary was such that the hostile demonstrations known as the Pig War resulted in the complete closing of the Austrian frontier. Matters reached a climax when Bulgaria seemed to approve the annexation of Bosnia and the Herzegovina by the Austro-Hungarian Monarchy. In regard to this, however, there was a complete misunderstanding, because King Ferdinand had declined to cooperate in the overthrow and extinction of Servian independence. It is clear, therefore, that something most remarkable occurred in securing Servian support for the Balkan alliance. The common gossip is that the revolution in feeling was the work of a Montenegrin princess, who had become the consort of a Russian grand duke, and had urged Iswolsky, the Russian minister, to make 
friendly and attractive suggestions to Milovanovich, the Servian prime minister, as early as March, I9ro.

We have referred to the preliminary conversations at Sophia in I9II. The definite proposition was the direct consequence of the Turco-Italian war, and formal negotiations were inaugurated almost immediately at Sophia. These negotiations were likewise intended to be secret, but two Bulgarian statesmen and one Servian minister were admitted to the discussion; and, further, one Russian grand duke, present at Sophia when Prince Boris came of age, somehow. learned what was going on. Accordingly, as might have been expected, some one of the initiated was indiscreet, and the Serbo-Bulgarian treaty was known to the world earlier than was that between Greece and Bulgaria, which actually preceded it in point of time. This treaty was almost identical with the other, except that it contained a series of territorial delimitations, provided there should be a conflict with Turkey and the event be a success.

This addition was due to the greater military strength of Bulgaria and the desire of Servia to have a due share in the booty. It was the weak spot in the compact, because it endeavored to combine the Servian plan of partition with the Bulgarian scheme for Macedonian autonomy. Old Servia and the Sanjak of Novi-Bazar, lying between the Rhodope and Shar mountain ranges, were to be Servian; the territory south and east of the Rhodope and the Struma River was to be Bulgarian; what lay between was to be an autonomous Macedonia. Moreover, this treaty exhibits some elements of distrust in the fact that, in order to render it more solemn, it was signed personally by both Servian and Bulgarian kings.

Content of SerboBulgarian Treaty 
The

Military

Conventions

Montenegro

Joins
Within a comparatively short time the military arrangements between the three Balkan powers were completed, and had taken definite shape before the general mobilization of September, 30. Bulgaria was to mobilize 200,000 men; Servia 150,000 as a minimum. In fact, when their armies took the field they were twice these numbers. Anticipating that Macedonia would be the battlefield, Bulgaria was to dispatch I00,000 men into Thrace, and as many more to Macedonia. Were Austria-Hungary to intervene, Bulgaria would send 200,000 men to Servia's aid, while Servia promised 100,000 for use against Turkey. Their anticipation was, of course, based upon reckoning which proved to be false; and subsequently, of necessity, the Servian and Bulgarian military staffs were compelled to draw up a series of conventions which abrogated the military arrangements of the treaty. As between Greece and Bulgaria, the military convention was signed on September 25, 1912, four months after that between Servia and Bulgaria, whereby Bulgaria undertook to put 300,000 men in the field and Greece I 20,000. Should Turkey attack either, these forces were to be joined, although each power retained the right of forming and adopting its own plan of campaign. The Greek fleet was to control the Egean, and prevent Turkey in Europe from drawing upon the resources of Turkey in Asia.

The Balkan alliance was completed by the adhesion of Montenegro. Indeed, as early as I888 King Nicholas had memorialized Russia on the subject of such an alliance. These representations were renewed by him in July, I9I I, before the outbreak of war between Turkey and Italy, and, immediately thereafter, he made general proposals to his three stronger neigh- 
bors-Servia, Bulgaria, and Greece. From time to time slight advances were made, and finally his arrangements, purely defensive in nature at the outset, with each of the three powers, were completed during the summer of I9I2. The only important reserve was in the treaty of alliance with Servia, wherein it was stipulated that there should be no combination of military forces and no joint occupation of any Turkish town or village. During the war with Turkey only one event gave umbrage to Montenegro- the march of the Servian troops on Allessio and Durazzo.

The house of Nyegosch has seemingly sought to emulate the policy of the house of Savoy, with which it has now at least a marriage alliance, the queen of Italy being a Montenegrin princess. It was long ago said that Italy was taken leaf by leaf as a man eats an artichoke. King Nicholas, therefore, regarded, as did his ministers, this latest conflict with Turkey as a means for the enlargement of Montenegrin territory. Since the days of Peter the Great, Montenegro had owed the considerable measure of independence it has enjoyed almost entirely to Russian patronage. By the Treaty of Berlin the kingdom had secured an outlet to the sea. What the Montenegrin Slavs believed to be their natural boundaries were mutilated by the Austrian occupation of Dalmatia. In that direction expansion was hopeless; it now seemed possible at the expense of Turkey. To quote again the highest Balkan authority, Bouchier, an English resident of Sophia: "The country had been at peace for thirtyfour years, a period unprecedented in its history. The mountaineers were spoiling for a fight; their yatagans were rusting in their scabbards; and the intervention of Europe, with a scheme of Macedonian 
reform, threatened to deprive them of their heart's desire. The liberation of the Macedonian rayahs was only a secondary consideration from the Montenegrin point of view; the main object was to obtain a 'place in the sun,' and, in order to achieve it, King Nicholas determined to force the hand of his allies." Accordingly, he took the field in advance of them all and opened hostilities, without a formal declaration of war, by an advance on the Albanian frontier.

There is, therefore, in the formation of the Balkan alliance much the same sort of historical evolution as underlies all important events, however startling they appear when announced to an unsuspecting world. What had been considered outside the range of human possibility had really come to pass. At the same time, even this short account of the evolution suffices to exhibit how powerful were the elements of dissension, both in national temper and interest. The real wonder is that the alliance lasted as long as it did, and was, during its short life, fairly efficient, and worked with as little friction as the outside world, at least, was able to observe. ${ }^{1}$

\footnotetext{
1 The treaties and military convention as published by the Paris "Matin" are given in the appendix.
} 


\section{VIII \\ NATIONAL CHARACTERISTICS IN THE LATEST WAR}





\section{VIII}

NATIONAL CHARACTERISTICS IN THE LATEST WAR

Some time since, a careful statistician published a Racial series of tables to exhibit the relative growths attained within the limits of the nineteenth century by AngloStrength and Saxons, Latins, Slavs, and Teutons. Influence, as the word is used, means square miles of the earth's surface and numbers of dwellers therein, whatever their race or color, now under the sway of the four white race stocks. The increase of Anglo-Saxon power is nearly five times; of Latin, nearly four; of Slav, exactly four; and of Teuton, two and a half. The elements in this calculation are, of course, somewhat uncertain, but it does seem to be significant that, contrary to general impression, Latin and Slav are not so far apart in their advance, while the Teuton is far behind, with the Anglo-Saxon an easy first. Considering the immense military superiority of the Teuton, and how amazingly prolific he is in comparison with his Western neighbors, the result in his case is surprising.

But one thing emerges distinctly: that even Teuton civilization, high and militant as it is, has a terrific struggle for life on its eastern frontier in the expansion of Slav power and numbers. The sovereign states of the Balkan peninsula so far enumerated are, with the exception of Greece, virtually Slavic, one and all; so, too, is the European portion of the one sovereign power still to be mentioned, Turkey itself- 
or (excluding Albania) what was known to late geographical parlance as Thrace and Macedonia. AustriaHungary has twenty-eight million Slavs within its borders-more than half its population; Prussia has probably six million and Russia about a hundred and fifty-five million Slavs; Turkey in Europe, with its ante-bellum extent of sixty-six thousand five hundred square miles, had a population under six million, and of these fully four million were Slavs. If anything appears to be manifest, it is that Eastern Europe, with a population overwhelmingly Slav-about two hundred million-is to be totally and entirely Slav; that it is to be composed of a federation of Slav states, larger or smaller. The few Turks remaining must return to their earliest home or be annihilated. This is PanSlavism, and the notion has a possibility so attractive to the peoples of that stock as to make this remoter ideal a real force in European politics. But, closely examined, it is a chimera, and this is best exhibited in the case of Macedonia.

The Folly of Pan-Slavism Illustrated
The term "Macedonia" is here used in its narrower sense, excluding Albania. This leaves a territory of about fifty thousand square miles, with a population of three million five hundred thousand, of whom possibly two hundred thousand are real Turks and perhaps as many more European Moslems. What the rest are has already been indicated: they are overwhelmingly Slavs-South Slavs. But what kind of Slavs? Bulgarian, Servian, or Greek? This knotty question has also already been broached in another connection; possibly a little, but only a very little, more light can be thrown upon it.

From the times of earliest recorded history there has been in Macedonia the cry, "Come over and help 
us." No other land in Europe has suffered so continuously from the desolation of battles, sieges, ravagings, burnings, forays. As has been remarked by one writer, it was a German Thirty Years' War prolonged to many, many centuries; the hand of every man against every other man, whether in state, province, village, or family. Pelasgians, Greeks, Romans, Byzantines, Crusaders, Genoese, Venetians, Huns, Avars, Bulgarians, Servians, Wallachs, Albanians, and Turks have overrun, devastated, settled, fled from, and turned back to its borders. What would otherwise be a garden-such are its splendid resources in soil, minerals, rivers, forests, and pastures-has been kept almost a desolation. It could support in peace many, many times its present population; but peace seems further off than ever. Before the war bandits were derailing railway trains, Bulgarian bands were stirring up strife, robbers were holding European captives for ransom, Albanian rangers were threatening the villagers and herdsmen, feeble Turkish authority was reveling, wherever it formed its camps, in harsh repression. What else was going on news gatherers did not discover; but beyond a peradventure there was rapine and bloodshed to an extent which beggars description. Bouchier, so often mentioned as the very foremost authority among Englishmen in regard to the Balkans, a resident of Sophia, but well-known and welcome at the other Balkan capitals, openly charged a newspaper conspiracy to suppress horrid truths which were known. His explanation was that the Jews of Europe and America, having secured control of the most widely read newspapers, desired that the atrocities perpetrated by Young Turkey should not be known, at least not before the Turkification plan 
had had a longer trial. Moslems against Christians, he asserted that the powerful Jewish influence has been historically and must be temperamentally with the former.

Beyond a question the Slavs of Macedonia are Bulgarians, Servians, and Wallachs, but in most uncertain proportion. As far as Pan-Slavic aspiration goes, it has so far been blocked by the fact that five Balkan monarchies of Slavic character, besides Turkey, were each simply lusting for the possession of the other Slavic land. Besides, these South Slavs are separated by the whole orb in religion, strongest as yet in those parts of all the social bonds: some are Roman, some Greek, and some Moslem. For the ruling Turk there was no distinction between Bulgar and Serb, Roman and Greek; all were, in his own elegant language, "hogs in a sty." Accordingly, his task under the new regime could be formulated much more simply than under the old. The latter taxed and tolerated; it ruled pitilessly, but made no effort at political conversion. Snarling curs when cowed are less dangerous than conspiring rebels with civic recognition. The new regime purposed to tax and tolerate, but also to rule: and to give an unreconcilable peasantry an ostensible responsibility by further trituration in the mortar of administration with the pestle of compulsion. Said a well-known Prussian monarch to one of his subjects "Love me, hang you; I command you to love me." Said Constantinople to the Macedonians, "Be Turks, hang you; I command you to be Turks."

Macedonian Characteristics
It was an amazing idea for a constitutional Sultan to make a progress in Macedonia, exhibiting to its population in his personal presence the reformation, or, rather, the revolution, of Turkish politics-and by 
what? By the selamlik, as earlier stated, the defiant ceremony which emphasizes as often as performed the reactionary nature of Ottoman rule. It must be confessed these strange constitutionalists had some excuse: if the same Macedonian village could within the space of ten years be first Bulgarian and then Servian and then Greek, why not Turkish? The fact of such easy conversion in the Macedonian communities is attested by the best possible evidence. Why not? Life is sweet, and home and harvest and subsistence, however primitive and mean, are things to be desired. Bribery, too, is efficient in such communities. A French consul is reported as saying that with a few million francs he could make all Macedonia French. He would found schools and teach the children that all Macedonians were descendants of the French crusaders, who in the twelfth century had conquered and occupied Salonica. The nimble coin, simple bribery, would do the rest. What truths are spoken in bitter jest!

In a very broad and loose sense the Treaty of Berlin in 1878 was the partition, or at least the completed partition, of Turkey in Europe among the peoples who dwelt in it, Macedonia alone excepted. Only one of the Powers made a direct gain in territory: Great Britain took Cyprus and, thanks to the stupidity of her partners, has since taken Egypt. Had there been given to Macedonia a measure of the independence bestowed on the other Balkan States, or had her districts been divided among the new conterminous powers, the Turk would have departed from Europe altogether, as he has already in great measure. By nature a nomad, using his European house much as his forbears used an Asiatic tent, he has refused to re- 
main and obey where once he commanded; and pure Turks, not Moslem Slavs, have migrated over the Bosporus in vast numbers. But all the jealous European states represented at Berlin desired a weak and buffer power at Constantinople, and Macedonia paid the price. The solid profits pocketed by Great Britain long embittered the sister powers. Austria has since annexed the provinces intrusted to her administration and is quit. She holds them beneficently on the whole, and they enjoy a measure of autonomy, while making great advances in social and economic lines. There is far less discontent than had been expected. But Macedonia, the beautiful martyr, and Albania, undaunted, untamed, the only bulwark against a further swell of the Slavic wave-what of them?

The Plight of Albania and Macedonia

The work of Turkification began in Macedonian cities-Salonica, Monastir, and Ueskub. In them was garrisoned the flower of the Turkish army created by Abdul Hamid, and the Young Turks won the troops for their plans. Terrorizing could go no further than it had gone; soon there would be no Macedonia to rule or tax. Europe would intervene and Ottoman rule in Europe, already burning low, would be extinguished entirely. The revolution was accomplished and the will-o'-the-wisp began to dance. But the Albanians were distrustful of marsh gas. Fed on promises for a time, they found that nothing happened, not a single substantial gain for their cherished hopes; the price of Albanian loyalty was not paid, there was not even earnest money. Tosks and Ghegs, Moslems and Christians, they grew restless and bitter. Finally, rebellion burst forth. The new Turkey knew no other methods of procedure than those of the old. The 
former conditions were bad, the latter worse. It was only by the united behests of Russia and Austria-Hungary that the conflagration was held in bounds, kept an internal Turkish question; and that through wholesale concessions which only emboldened the wild Albanians to demand more and more. It is the dread of extinction which forces Young Turkey to desist from utterly Turkifying Malissores and Mirdites. Wildest, rudest of their blood, Roman Catholics at that, these Albanians have rebelled; they fought and won; the Albanian was to wear his arms, perform his military service at home, have his own schools conducted in his own language, be ruled by Albanian, not Turkish officials-in short, secure his substantial autonomy as the price of refraining from further agitation or from making common cause with Montenegro, which in turn was assured of Servian support in case of trouble.

As for Macedonia, her latter state was even then worse than the former: and equally wholesale concession must be the order there as well. But Albania is a political person-composite of clans, stocks, and chieftains, but yet united-and there is a party of the second part to close a contract. In Macedonia there is no such artificial personage, and it is surely the intention of the partitioning states that none should be set up. The way out was not then in sight. The dilemma appeared to be either perpetual outrage; or a European congress to make Turkish rule nominal, by setting up Christian governments like those in Crete and Syria or Egypt ; or finally the outbreak of war-war of the Christian states against the one surviving Moslem power, and then possibly war among the Balkan States themselves over the division of spoils, since spoils for some one there must be. The hatred and distrust- 
not suspicion, but utter conviction of bad faith-felt for the Turkish government and the men in power by their Christian subjects rendered regeneration absolutely impossible under Turkish rule.

The pleasant land of Macedonia could four years since be seen only from the railway, except by the adventurous. Daring Europeans were waylaid and held for ransom by banditti almost within the suburbs of the cities; instances occurred as late as I9I I near Salonica and Ueskub. The American public has nearly forgotten the capture of Miss Stone, the missionary, though it was less than ten years ago that it took place; but the seizure of Professor Richter by Greek komitadjis is still recalled. Lives of the natives were being ruthlessly taken by the ruffians; those of captured tourists were a valuable source of funds. This means of securing money would have been indefinitely extended had travelers been rash enough to penetrate further, even though their lives should be spared. In Albania it is doubtful whether for some time to come the life of a tourist would be safe for any reason in the hands of the fierce, untamed rangers.

The railway line from Constantinople to Salonica is about six hundred miles in length, that from Salonica to Ueskub about four hundred. It is not long since the principal occupation of the Turkish army was the guarding of these railways and the protecting of roadway, bridges, tunnels, and trains ; passengers saw from their windows more soldiers than civilians. While there was hope for the fulfillment of the lavish promises made by the Young Turks, a relaxation of vigilance was possible; but hope soon vanished and the operations of the bands were immediately renewed. Their forays were intermittent but frequent, and out- 
rages on the lines were numerous. There was every prospect that without military protection the railways would soon again be unsafe.

The general aspect of the country between stations was probably that of the remoter parts also: wilderness and thicket, with here and there sparse groups of tired peasants, cultivating enough land for subsistence, but with the discouraged air of those who sow where they may not reap. Discouragement is a word which utterly fails to express the Macedonian mind: the people lived in blank despair. It is doubtful whether they still have energy enough even to hope; they certainly have not enough for any efficient action.

It is not very long since the writer had an opportunity to look at refugees from the villages of both northern and southern Macedonia: some in Sophia, orphan children for the most part, whose parents had been foully murdered either by Turkish soldiery or by the abandoned, infuriated komitadjis of various nationalities, others in Athens, families composed of husbands, wives, and children. The aspect of the poor souls was heartrending; lack-luster eyes, slack limbs, dragging movements, general indifference; utter worthlessness would be the first verdict. But it was amazing how quickly they responded to kindness, regaining their powers as rest and nourishment revived body and soul. But their physical recuperation is simpler and easier than their moral regeneration. Generations must probably elapse before manhood is revived, intelligence reawakened, and some initiative aroused.

The state of Bosnia and the Herzegovina was never as low as that of Macedonia, yet even in those provinces the evil qualities engendered in the Christian

Conditions in Bosnia and the Herzegovina 
population by cruelty and tyranny are far from being eradicated. Almost universally, the well-informed in those provinces express much hopelessness as to the improvement of the present conditions. The native Christians are charged with guile, effrontery, deceit, and idleness. As a dweller in the country said in conversation: "They are as idle as the dormouse, as bold as the bedbug, and as deceitful as three Galician Jews. These creatures," he continued, "could only be managed by the Turks, who understood them and trusted them not at all, enforcing a day's work for a day's pay, compelling every outward sign of deference and punishing delinquencies without mercy." Making all allowance for the exasperation of an employer-indeed, the language quoted was evoked by a cringing, servile effort to collect a pittance for services never rendered-discounting all the exasperation produced by race hatred, there is yet certainly a large deposit of truth at the bottom. No wonder the tricky laborers are what they are described as being; probably the wretched Macedonians may be worse. Yet it makes little difference who perpetrated the foul wrong which degraded so many of God's noblest creatures; the problem was urgent and difficult. Alas, that the revolution at Constantinople, could do little, indeed worse than nothing, to improve anything; that events in Albania, even the latest, will probably aggravate the Macedonian situation to the limit; and that the policies of the great powers seem to block any hope of progress.

Näiveté of

Balkan

Claim of "Christians"
In the primitive days of the theater the stage-setting was so innocently naif that a rude boor needed only to declare that as he stood there he was a wall, and that as he held up his hand and opened his fingers in two groups this was the chink through which lovers, 
otherwise separated, might exchange their vows; the imagination of the onlookers supplied all the rest and the deceit was utterly forgotten. We of the Western world are quite as naif as our ancestors of centuries ago in our consideration and judgment of the Balkan peoples. They have placed themselves in the center of the stage with a claim to represent a high civilization in revolt against a degraded one; they have proclaimed to the world that they were Christians practicing Christian virtues, organizing under frightful discouragements Christian civilizations. The nations of Europe have been disposed for their own purposes to accept these claims in measure, but it is no overstatement to say that the masses in our own country and in other Western nations have accepted them literally. For perhaps a decennium tourists who considered themselves adventurous have visited, to their great delight and to the furtherance of their education, many portions of the Balkan peninsula. Being one of them, the author has compared his own observations with those of others like himself, and found it, even after a certain degree of experience, impossible to think otherwise than well and kindly of the South Slav peoples.

No wonder, therefore, that the general impression about them was what it was. The recent conflicts Atrocities of the War have caused terrible disillusionment. As far as regular warfare was concerned, each of the Balkan nations was under the tutelage or followed the tradition of some Western power. The brief outline of the campaigns previously given, though a mere sketch, has made manifest that the decisive struggles were not those of well-ordered battlefields; even the sieges, which were in a measure decisive, have been conducted 
to a successful end by the exhibition of rude, personal, furious courage, rather than by a scientific cooperation of the forces engaged. But as far as the truth, difficult at all times and everywhere to secure, has been permitted to be told, despite the rigid censorship of both civilian officials and military officers of the various nationalities, it seems manifest that victories have been won with an exhibition of atrocious brutality, indicating a desperate barbarism among the combatants. The atrocities practiced by Turks and Moslems at the beginning unquestionably set an awful example, but that these so-called Christians have perpetrated worse horrors no longer admits of any doubt. It is with sorrowful regret that we admit our disenchantment, especially in regard to Greece, where such brave beginnings in the arts of peace, in the development of humane sentiment, and in the foundation of an enduring civilization have been made. Fury begets fury we must admit, and somewhere there was a beginning of horror. Whether efforts have been made by enlightened leaders to check the frenzies of those in the ranks we cannot know. The awful truths constitute an indictment which lies not against any one of the combatants, but certainly against two to the highest degree, and probably against the other two as well.

In their mutual recriminations, hard facts, probably exaggerated, but nevertheless facts, have been proclaimed to the world by the highest royal, military, and civil officials. We have heard of children murdered, of women ravaged, of men maimed; we have read about the gouging of eyes, the hewing of limbs, the slashing of faces; we are told of human beings saturated with oil and set on fire; of persons buried to the neck and abandoned to a slow death with 
basins of food and water before their eyes; of bags found by the wayside filled with women's ears that still contained the inexpensive earrings for whose sake the hurried ruffians had amputated them with swords; we might add an almost endless catalogue of shame and crime, but it is needless. Such bestial license is attributed to the example of the lawless banditti, the execrable komitadjis; such atrocious deeds have been practiced for long years unchecked in the villages and districts for which the respective Balkan nations lusted; and all this has been in the name of nationality.

Our foremost English authority, to quote Mr. Bouchier once again, a personage kindly received not only at every court, as we have said, but in every household, either peasant or patrician, has published as his deliberate opinion that every one of the combatants has in greater or less degree been guilty of such atrocious excesses.

That there are honorable, high-minded, humane strata in the societies of all these people no one doubts; but, on the other hand, it does appear as if even Intellectual and Moral Corruption they had indulged in pitiful fallacies, and had been contaminated by the memory and repetition of phrases and deeds. Quite possibly, such charges may not be proven against the operations of regular soldiers, but like a band of demons the bloody guerillas hovered on the outskirts of every army; they proclaimed their law to be that of retaliation; they declared that all was fair in war; they created chaos and anarchy on every side; it does appear as if they finally succeeded in finding support for the doctrine that what elsewhere under other conditions would be immoral, disgraceful, and shocking was then and there perhaps peculiar, but great, good, and grand. Their light became darkness; 
their humanity became a perverse and criminal brutality. Perhaps the most dreadful publication in this connection has been that of a translation made by the Greek poet, Paul Nirvana, from the rhapsodies of a Bulgarian writer, Ivan Arkudoff, who, according to some reports, is a person favorably received in the highest Bulgarian circles. Here is a specimen:

"Before the day-star marks the seventh degree above the horizon shall the sea of blood, which thy sword unseals, flow seven fathoms higher. Behold the aged cripple, who drags along his wretched, senile life to escape death and thy fury. Trample him under foot with iron heel; gouge out his dimming eyes, unworthy ever to mirror Bulgaria's grandeur.

"Why linger, young Bulgarian? Forward, ever forward!

"Softer than the flowery meads of spring is the carpet woven from the corpses of murdered women and boys. Refresh thy soul in the perfume of their youth, and then, tipsy with passion and heroism, strew flowers upon the earth, and march forth as if you were treading the velvet rugs of a palace."

The Greek translator speaks with sneers of this Bulgarian Pindar, poet to the court; denounces him with execration and scorn. While as yet the Bulgarian retort has not been given entire to the world, and while one shudders at its possible content, considering the charges of murder, rapine, and desperate brutality already made against both Greeks and Turks, yet what this Bulgarian has written, he has written, and no primitive savagery, no desperate barbarism, no shred of the wildest war-song of primitive man has ever furnished anything comparable to it. The words and the spectacle are alike disheartening and repellent. 
During the last stage of the war Bulgaria was so hemmed in on every side that virtually all communication with the outside world was temporarily shut off. No sooner, however, were treaties of peace signed and communication restored than the Bulgarians became aware that they were a subject of reprobation to the entire civilized West. They immediately organized a service of emissaries to go to and fro in America and Europe in order to present their version of what had actually occurred in regard to the atrocities with which they were charged. A Bulgarian officer challenged the well-known Frenchman of letters, whose pseudonym is Pierre Loti, to a duel because of what the writer had said and published in reprobation of Bulgaria's barbarism.

The government at Sophia has likewise published and circulated two pamphlets containing letters in facsimile of Greek soldiers of the Nineteenth Regiment, written from various camps to their homes and intercepted between the 14th and 27th of July, 1913. Short excerpts from two of these letters may fairly represent the substance of them all. A certain Philippos writes, on the I Ith of July: "This war has been very painful. We have burned all the villages abandoned by the Bulgarians. They burned the Greek villages and we the Bulgarian. They massacre, we massacre. And against all those of that dishonest nation who fell into our hands the Männlicher rifle has done its work. Of the twelve hundred prisoners we took at Nigrita only forty-one remain in the prisons, and everywhere we have been we have not left a single root of this race." Another common soldier, Karka, on the 12th of July, 1913, indited these words: "By order of the king we burned all the Bul- 
garian villages because the Bulgarians burned the beautiful town of Seres, Nigrita, and several Greek villages. We have behaved much more cruelly than the Bulgarians, because we have violated all the young women we have seized." Other sentences which occur here and there in various epistles are as follows: "We have only taken a few prisoners, which we have killed; such are our orders. I took five Bulgarians and a girl from Seres. The girl was killed and the Bulgarians also suffered. We picked out their eyes while they were still alive." Still a third: "It is impossible to describe what happens. God knows where this will end. The time has come for us to start eating one another." As a supplement to the text, there are given declarations from the inhabitants of the town of Seres, who describe their escape from Greek atrocities as miraculous, and also photographs of the victims showing ghastly wounds inflicted upon them by the Greek soldiery. These photographs are comparable only to such as might have been taken in the shambles of unskilled butchers.

As, of course, was to be expected, these narratives have been stigmatized by the Greeks as awkward forgeries. Where the truth lies it is hard to discern, but certainly as yet even most dispassionate judges have been more severe in meting out just reprobation to Bulgaria than to Greece. The substance of the Bulgarian plea, official and unofficial, is for a suspension of judgment in view of anterior provocation. King Nicholas of Montenegro, it is declared by the pleaders, accompanied by the Greek, Servian, and Bulgarian ministers at his court, visited the hospitals in Tzetique, and found in one of them, lying beside a patient, a bag which on examination proved to contain noses cut 
from the faces of Turkish soldiers. This, of course, sounds like a counterplea for the bag of ears cut from Greek women for the sake of the little earrings which they still contained. Furthermore, a captive whose name was Beleff, one of those who had escaped from among the heaps of Bulgarians massacred in the town of Seres, bore testimony to the brutality and ruthlessness with which the Greeks had treated their prisoners. He himself had six wounds, each of which would have been considered fatal. This again, though strictly true, is a " $t u$ quoque" to the familiar Greek charges. In the same connection, however, Professor Mattheeff admits that under cruel provocation even Bulgarian regulars have not acted with self-restraint, and that the komitadji bands, each of which had some special wrong to avenge, have not clean hands in the matter of atrocious murder. He asks merely that Bulgarians should not be considered monsters, while the Greeks are held up as saints.

This kind of pleading is familiar to all who have the slightest acquaintance among people of primitive civilization. To the rather childish excuse he adds the significant remark: "The Eastern question is as far from being solved as ever. . . . Our mistakes never merited such a humiliation, nor such a despoilment, one without precedent." The Greeks, he further declares, when withdrawing from territories once occupied by them, but now assigned to Bulgaria, burn and destroy every vestige of property which had escaped destruction during the eight months' warfare, and announce to the world that this destruction is the work of the inhabitants who cannot endure the thought of living under Bulgarian rule. In another published plea Professor Stephanove denies that Bulgaria was 
the aggressor in the renewal of the Balkan wars. His colleague admits that quite possibly Bulgaria had not acted wisely in the renewal of hostilities! That although her cause was just, quite possibly she should not have exacted the letter of her bond!

Such a parallel between two apologists indicates the national temper. No one dreams for a moment that the Bulgarians are, without exception, utter savages. What has previously been said sufficiently proves how marvelous has been the development of the people under leaders educated in the arts of peace. But, after all, in every nation, the foremost men, the best elements in the population, feel their responsibility in the behavior of the nation as a whole, and whatever may have been the sins of others, there is a profound impression throughout the Western world that the Bulgarian outrages were the most frightful perpetrated, with the exception of those committed by the Turkish Bashi-bazooks; and that during the conflict these outrages were well known at headquarters, and were not reprobated sufficiently even to mitigate them.

Professor Stephanove calls the secret treaty concluded in May, I9I3, between Turkey and Greece, a conspiracy. Bulgaria at the height of victory was not an inspiring spectacle. She permitted substantially no news to reach the outside world, and the little which did percolate through various channels to foreign ears led to the general belief that her conduct of the war was ruthless and that her victories were largely won by brutality. Add to that fact the further profound conviction that her guerilla bands were quite the most active and apparently the most desperate; furthermore, that as time went by she manifestly intended to reap where she had not sown, as, for instance, in the 
case or Salonica. Can we wonder that Rumania, Servia, and Greece saw in her a power destined, unless checked, to become dominant in the Balkans? Was there any fallacy in the reasoning that it would be better to curb that power at once than permit themselves to be annihilated in the near future? In any case, an understanding was reached, whether honorable or dishonorable, whereby Greece promised armed assistance to Turkey for the reoccupation of Adrianople in return for Turkish aid in the seizure of southeastern Thrace by Greece. It was then that Rumania intervened, attacked Bulgaria in the rear, compelled a cessation of hostilities and eventually the disarmament of her southern neighbor.

In the effort, therefore, to judge the situation dispassionately we come to the disheartening conclusion that dishonor, atrocious brutality, and entire absence of chivalry have marked the conduct of the war by most, if not all, of the combatants. We might have been disposed to think Servia the most innocent, were it not that the commission of the Carnegie Peace Foundation in its efforts to secure the truth and enlighten public opinion far and near, and to stamp with authoritative if not final judgments the numberless rumors, met with such scanty courtesy in Belgrade at the hands of the Servians, who seemed utterly unwilling to give evidence sufficient to acquit them of very similar behavior. We cannot think that the choice of Professor Milyukoff to head that commission was entirely wise. It is true, indeed, that he is a man of high quality, thoroughly familiar with south Slavic conditions, and a genuine liberal. But he is nevertheless a Russian and, therefore, subject to the suspicion, however unmerited, of sympathy with Bulgaria. The 
commission passed on under his leadership to Salonica, where it found more consideration at the hands of the Greeks.

Sir Edward Grey emphatically declared before Parliament that Europe had not often, if ever, witnessed a more distressing spectacle than the progressive events of these wars. Beginning on the plea of liberation, they became a struggle for conquest and ended as a war of extermination. This latest word, "extermination," was first used in southeastern Europe itself, and the British statesman hesitates to accept it as literally true. But alas! the more we know the more we feel that all the conflicts have been no better than a human conflagration. The wars must be over, for there is no physical strength or available property, real or personal, which has not been exhaustively used in the struggle.

Corroborative evidence of this fact has just been published in a report from Ashmead Bartlett, whose name is a guarantee, both for his keenness as an observer and the accuracy of his descriptions. He says: "I have been fifty kilometers beyond the Turkish advanced posts, and I am the first independent eyewitness who has visited these parts since the outbreak of the war. I have just seen sights and have been through experiences which I never wish to go through again. I have had deputations of the surviving inhabitants. Both Greeks and Mussulmans beg me with tears in their eyes to do something for them, to expose their wrongs to Europe, and to lay their cause before the Powers so that something may be done for them in the future. . . . The state of these districts west of the Maritza which I visited defies all description. The country looks as if it had been swept by a 
terrible earthquake, or as if a horde of Huns under some modern Attila had made a clean sweep of everything in their onward progress. . . . Again I can only repeat, let an impartial commission be sent out to investigate the truth of the charges I am obliged to make against the Bulgarian army. It is almost impossible to believe one is living in the twentieth century with such evidences of man's ferocity all around. The experience is more like reading some chapter of ancient history describing the sweeping away of the decaying Roman empire by hordes of barbarians from the North; but in a telegram it is impossible to do justice to what I have seen."

It is a maxim of justice that every person and all peoples have a right to be judged from the standpoint of their own position and culture. The more closely peoples in different stages of development have been brought in contact with each other and under observation, therefore, by critical travelers alike of the upper and the lower strata from each and all the nations, the more severe has become the condemnation of the faults and vices of the foreigners. The Balkan peninsula has been properly called an historical laboratory. Not only are scores of race elements there commingled, but the identical influences and similar manners which were at work further west three centuries ago are still dominant. It is, therefore, utterly unjust to regard the recent infernal and atrocious conduct of the Balkan peoples, which it distresses us even to mention, from the point of view of what is styled in our Western world humane warfare. To the dispassionate observer it is manifest that these people, tottering as are their footsteps, unchastened as are their passions, childish as is their disci- 
pline, are nevertheless struggling forward along the path of progress. We dare not condone their faults nor mitigate any outraged estimate of their behavior, but we should and must offer them a helping hand. It is our bounden duty to lay upon them the rod of moral correction, and, above all, we should offer for this crude but nevertheless dawning civilization the type of example which far transcends in its influence either indignation or attempted tutelage.

The Powers and the Treaty of Peace
The alliance of the South Slavic powers was, of course, a mere temporary expedient; but it worked for a time, and deserved more respect from those who were parties to it than was manifest in the shocking outburst of greed exhibited even before the boundary line of European Turkey had tentatively been fixed by the European conference, and the treaty of peace as between Turkey and the alliance signed by the plenipotentiaries. The concert between the great powers themselves was loyally maintained. When all the considerations, historic, economic, racial, and religious, which have hung in the balance, are taken into account, it is amazing that a body of statesmen, sharply divided into two groups by the Triple Alliance and the Triple Entente, should, for the single reason of preserving peace, have been able to arrange what was at least something more than a truce, a temporary treaty. Retribution as regards nations is almost as certain as in the case of individuals. The repeated and defiant violations of the Treaty of Berlin within the first thirty years after it had been so carefully promulgated as the public charter for all Europe did not pass unnoticed in Turkey or in the Balkan States. There was a day when men talked at least about the inviolability of treaties. For two generations 
past the great treaties have been made apparently only as prize fighters spar for wind and gain time by feints.

Nevertheless, the statesmen assembled at London evaded the most difficult of all the questions arising from Turkish discomfiture: the question, to wit, of how the victorious Allies would divide among themselves the conquered territory. One of them has declared that they "trusted, as all Europe and as all the world trusted, that this would be found to be a matter for mutual and friendly agreement between the parties concerned." Immediately before them, and under their very eyes, had been, in the meeting of the plenipotentiaries from the various states concerned in the war, a perfect example of Oriental diplomacy, procrastination, and guile. The ambassadors were indeed a trustful body, and their trust was the more simple in that they, they alone, were responsible for having injected into the already seething, boiling caldron of Balkan politics an absolute novelty; the delimitation of Albania and the settlement of how far it should or could be self-governed, and of how far it should be a protectorate, and of whom.

Enough has been said about Bulgaria to indicate Bulgaria's that little surprise was felt when it appeared that she Mistake proposed for herself the lion's share of the prey, which, as considering herself the lion in the onslaught, was hers by right. This was, for the time being at least, her undoing and the cause of her deepest humiliation. She has never since the declaration of her independence found herself in a plight so sorry. It taxed all her powers, and to the very utmost, to meet the main forces of Turkey, which was her task in the war; and it was in a panting exhaustion that her troops 
entered Adrianople. Had she been in the hands of really able statesmen, and her troops been led by a wise commander-in-chief, she would have realized her incapacity, at least at the moment and for years to come, to make real the vision of a Great Bulgaria. Through the storm of recrimination it is hard to discern how far Prime Minister Daneff and Commanderin-Chief Savoff represented public feeling or yielded to an irresistible public pressure, when they assumed an arrogant offensive against their recent allies and reopened the bloody strife. Whatever the case, great men would somehow have restrained the mob and by constitutional measures secured the necessary delay for recuperation. As it was, it is now manifest that in the mad venture Bulgaria could gain nothing and must lose much.

Autonomy for Macedonia

Balkan statesmen, so called, are charged with being utterly disingenuous; and in support of the charge it is pointed out that Bulgaria's demand and policy as regards Macedonia is what is known as flying a kite. She naturally expects to cast off her sackcloth and ashes; she still hopes for pity and protection from a Western world which so long admired her as a patient, powerful people, developing high qualities under firstclass statesmanship; what she still desires is exhibited in the proposals she has vainly struggled to enforce for the complete autonomy of Macedonia. There seems no doubt that, having secured so much, she would exert efforts to bring about with an autonomous Macedonia what previously happened with an autonomous Rumelia. Having shown, on the whole, a higher capacity than any of the conterminous states for selfgovernment, she obtained a hearing for the incessant iteration of a truth; that the districts of Monastir and 
Ochrida were Bulgarian. About this there was such a perpetual clatter that Greece could get no hearing as to what was equally true, namely, that Chalcidice, Drama, and the whole shore line were Greek, except that the trading city of Salonica, with its wonderful harbor, is first Jewish and secondly Greek.

From these considerations it is perfectly evident why Greece bitterly opposed autonomy for all Macedonia, but urged it for the Greek-speaking districts of that province, a proposition quite as far from being disinterested as that of Bulgaria, inasmuch as when time and opportunity were ripe an autonomous Greek province would fall into the lap of Greece. Either proposition would simply have reproduced the old horrible conditions. Bulgarian bands would be making propaganda in such a Greek principality, and in an entire Macedonia the identical, unregenerate komitadjis of Bulgaria, Greece, and Servia would be carrying on their fell work. Quite possibly, the fate of Salonica is a question by itself. There has been a suggestion that it should be jointly occupied and held by Greece, Servia, and Bulgaria; another that Bulgaria should occupy it and not possess it, being the only one of the three powers likely to develop sufficient strength to protect it, and that in the long run she would seize and hold it anyhow. Then there were the questions of Servia's access to the Adriatic, of territorial compensation for Montenegro, and of the neutralization of possibly the most important sea channel of the Adriatic, namely, the Straits of Corfu between that island and the mainland. The situation contemplated in the London treaty, which sought to establish the Enos-Midia boundary line for Turkey, contemplated a state of things which within two months appeared as anti- 
quated as if the interval had been two centuries, so swift was the crumbling of Bulgarian power.

The perpetual cry was "Peace, peace," but apparently there could be no peace until all the parties to this quarrel admitted their utter exhaustion and negotiated among themselves some patchwork containing provisions to which they would pay regard only as long as their exhaustion lasted. An English statesman admitted in Parliament that armed intervention by Great Britain was impossible. $\mathrm{He}$ dared not state, but he must have considered, that to compel peace, decency, and amicable relations among these semicivilized peoples, intoxicated with Western ideas, utterly unsuited to them, and which stormed through their veins like poison, was chimerical.

Enter

Rumania

This was the juncture where Rumania entered upon the scene and invaded Bulgaria. Were a nation a personality, its neighbors might charge Rumania with a policy of cold, calculating selfishness. While wars were raging to the south, she was strengthening her finances, perfecting her military power, and consolidating public opinion within her borders. Her wily leaders were on the Balkan watch tower, viewing the southern horizon, keenly eager to seize the swiftly coming opportunity for aggrandizement-regulating the balance of Balkan power, they called it-by swooping down upon what they intended to be their share of a booty, in the capture of which they had not in the least assisted. The tendency, however, to speak of nations as if they were human personalities, has become the most subtle fallacy of modern life. Nations can feel human emotions collectively only in so far as they have common worldly and material interests. Devotion to a common form of Christianity is universal in the Bal- 
kans, but it has produced no Christian virtues in international relations; quite the awful contrary. Neither spiritual nor æsthetic community of interest can allay material rivalries.

It is the plain, unvarnished truth that a statesman's duty is to safeguard the material interests of his nation in the first instance; to remember that what does not grow is dead or dying; that the higher welfare of those whose interests he represents is a sequel to the peace and contentment which come from comfortable living. National afflictions, like human sorrow, are necessary for reproof and chastisement, but it is not the concern of statesmen or princes deliberately to provoke them. Viewed from this standpoint, Rumania's conduct has been marked by the highest degree of worldly wisdom and common sense. It is accepted as a fact, though as yet there is no proof, that at any time she would have joined hands with Bulgaria to "correct their common frontier"; in other words, secure from Bulgaria an important cession of territory. Reproaches are heaped upon Bulgarian statesmen that they did not accept such an opportunity, yield to Rumania the desired piece of shore line on the Euxine, by her aid hold firmly the much more valuable lands won from Turkey, and then force upon both Greece and Servia a settlement equable to all, which would have forever laid the devilish spirits which have held Macedonia as a fief of Satan himself. Whether or not the Rumanians are fine soldiers, their generals great strategists and tacticians, is of course uncertain, and therefore there is nothing to be said about the behavior either of them or of their kinsfolk, the wild Vlachs, amid the horrors of war. They were not called into activity and we know nothing of their 
possible behavior; we only know that at the hands of the komitadjis their related tribes in Macedonia have suffered little molestation and have remained strangely passive.

As once before, Albanian turbulence may at any time menace, if not disrupt, the bonds of Balkan peace. In October, I9I3, civil war was raging among the clansmen of the new nation. The provisional minister of war, Mufid, was marshaling the Turkish sympathizers against the rebels under Essad, who unfurls the Austrian standard. Albanian emissaries were appealing for support to their compatriots within Servian boundaries. The Servian government, convinced that this was the work of former foes, was preparing to reoccupy the strategic points she once held but abandoned at the behest of Western Europe. Similar events have been recurring ever since.

Servia and Greece

Thus far the most striking phenomenon of contemporary Balkan history is not the awakening of national consciousness in Albania, as many claim. Most cool observers believe that feeling, if not actually created, at least to have been artificially promoted by the two great powers of the Adriatic in order to secure the tenure of its eastern shore by feeble and quarreling little nations.

Nor, it must be confessed, has Montenegro fulfilled the promise of her early history: her men have fought gallantly, her women have slaved uncomplainingly, but her achievement was, after all, slight. What military strength and personal courage could not accomplish, the capture of Scutari, was, it is to be feared, brought about by a rather low conspiracy in part; in part by stolid endurance, and was concluded with a showy boastfulness that made the performance theatri- 
cal and tawdry. The central, outstanding, commanding fact of the conflict has been the moral revival of both Servia and Greece. At no time were the Servian komitadjis as numerous or as vicious as those of the other powers, and the reactionary effect of komitadji brutalities was less than in Greece. Moreover, the people are vastly less impressionable and mercurial than the Greeks, being of pure Slav blood and having no intermixture of Mediterranean excitability and vivacity in their stock. They have not developed great statesmanship, and the blot of conspiracy still deprives their royal house of any luster; nor have they developed any extraordinary military leadership. But they have shown admirable powers of organization, cooperation, and self-restraint; they have fought stubbornly and even gallantly; and their military leaders, if not brilliant, have at least been safe. The result of all this must be the final emancipation of Servia from the galling economic tyranny of her neighbors, a substantial increase of territory, and a sobriety in the conduct of her affairs. Her temptation, of course, is the "Great Idea" of the Great Servia, but she has before her the awful warning of what happened to Bulgaria in the mad pursuit of the corresponding "Great Bulgaria" idea.

It is difficult to be just to Greece. She owes her existence in a measure to the spirit of her own people, but in still higher degree to the philhellenism of the Western world. There have been epochs in her newer life when her conduct was altogether creditable, but there have been longer epochs where she has behaved like a naughty and irresponsible child, squandering her fortunes, jeopardizing her repute among the nations, boasting an enterprise which she did not possess, 
and generally perplexing the friends and lovers of a land felt to be consecrated in the history of thought, of culture, and of art.

As if in the twinkling of an eye her peoples became grave; they formed and cherished a solemn purpose; they made immense sacrifices, and that without observation, to accumulate a substantial war fund; they passed through a constitutional revolution fomented by military circles without civil war or anarchy; they subjected themselves to the sternest discipline after its completion; they restored free government and knitted up a strong and working national organism. Thoroughly prepared and equipped in a measure disproportionate to their slender resources, alike by land and sea, they advanced on the outbreak of war to the fulfillment of the obligations they had assumed when the Balkan alliance was formed. Like their remote ancestors, they have always been a seafaring folk, and their new navy, tiny in comparison with others, effectually policed a great extent of waters, and won many victories which, though materially slight, were morally all-important. The base assassination of their king inspired them with a determination even more grim.

There came to the throne an excellent ruler, familiar throughout his life with the qualities of his people, educated in the best traditions of royalty by his parents and his consort, and exhibiting substantial capacity alike for statesmanship and for warfare. The so-called military revolution, a movement for producing greater efficiency in both army and navy, inspired by the officers of both, originated in 1909 and was successfully concluded in I9IO. For a time it actually suspended constitutional government. Neither Con- 
stantine nor his pleasure-loving brother was slow to learn the lessons it so thoroughly taught. The new king is a devoted soldier. But, what was more interesting still, the hour produced the man-the statesman of controlling, constructive power. From among the Greeks of Crete there was brought to Athens a statesman inferior to none now living and superior to most. It appeared as if the strength and wisdom of Venezelos had taken possession of all the millions, speaking modern Greek within and without the kingdom of the Hellenes. In the ministerial Cabinet, in the deliberations of diplomatists, and in the formation of national and international opinion alike, his has been a commanding figure. The regular troops of Greece have throughout the war distinguished themselves by discipline and undaunted courage. The blot upon the good name of the nation was not created by national temper or impulse.

The Greek komitadjis have always been savage frontier banditti, lurking amid inaccessible cliffs, existing by murder and confiscation, and, in short, yielding in savagery to no others. That they have had some pecuniary assistance from individuals in the more civilized parts of Greece, from Greeks abroad, and quite possibly from agents of the Western powers, is the suspicion of great numbers. They have likewise enjoyed the sympathy of many sentimentalists among their own and other peoples, who could not possibly have been aware of their terrible deeds. For these reasons their romantic daring has had some retroactive effect in Greece itself. It was a matter for wonder and for some reflection when there began to emanate from Greek sources long telegraphic dispatches calling the attention of the civilized world 
to the atrocities permitted by Bulgaria. The question was, had the Greeks been practicing the guile for which of old they were renowned, and taking a leaf from the Bulgarian book? The agents they dispatched with much publicity to investigate the shameful deeds of others about which there was no question, might possibly have been better employed in investigating their own kinsfolk and ending forever the activities of both the Greek and the Turkish komitadjis along the frontiers of the northeast.

Summary

But whatever sadness may be felt in this regard by those without, there is no doubt that Greece and Servia alike have seen a new light, cherish new hopes, and have become powerful rivals for the hegemony of the Balkans to either Bulgaria or Rumania. That Rumania's intervention in the role of arbiter, especially in compelling peace, gives her a position of great eminence, must be unquestioned; but Greece has the foremost statesman, Servia holds the most critical frontier post, Bulgaria claims the strongest powers of recuperation. Turkey has been eliminated as a political force in Europe, except in so far as her tenure of Constantinople and her spiritual leadership of the Moslem world must ever keep her in wardship to the balance of power in Western Europe. May the temporary, if not final, readjustment of relations on the Balkan peninsula be sufficiently enduring for the respective states to indulge in a long period of selfexamination; may they recall at every moment the hideousness of the struggle in which they have been engaged, and may some elements of humanity, some sense of duty, some sacrifice of ambition to simple expediency enter into their public policies and permeate the private lives of their inhabitants. 


\section{THE SIX POWERS AND THE BALKAN WARS}




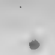




\section{IX}

THE SIX POWERS AND THE BALKAN WARS

"Le moment où je parle est déjà loin de moi," was Attitude and said of the swift movements in events a century ago by John Quincy Adams, in June, I8r3. It seems highly Temper of probable that our essay in contemporary history may "The Powers" be antiquated before it is printed. In the perspective of a few years hence, however, the temper of the great powers will certainly be seen to have undergone in this epoch a marked change from that which it had exhibited in the previous one. Already many writers occupy themselves with discovering reasons why their relations one to another and collectively to the rest of the world were marked by so high a degree of selfrestraint. Some insist that they were unready for war, or at least that they had not completed their arrangements for the increase of their armaments in a proportionate degree. Another opinion is that their dispassionate attitude was due to their fixed resolve not to allow any one of the Balkan powers or a federation of them to acquire strength sufficient to entitle them to consideration as a seventh great power. While it is true that the so-called balance of power and the peace prevailing between the great nations were in a condition of very unstable equilibrium, yet the course of events justifies our conviction that, as far as the public opinion of Europe was concerned, the new humane spirit which is everywhere manifest among the intelligent, intellectual, and thoughtful 
classes was sufficiently powerful to compel recognition, especially as the horrors of the struggle, growing ever more shocking, served as an awful example to the military and bellicose minority everywhere.

In any case, we have heard on the highest authority that from the beginning the Foreign Offices of London, Berlin, Saint Petersburg, Vienna, Rome, and Paris were of one mind as to the vital question of localizing the war. In this, throughout the long sessions of their ambassadors in Saint James's Palace, the two different sets of Allies heartily agreed.

Agreements

Their first care, of course, was to convince the general public that what had passed for axiomatic was utterly fallacious, namely, that should war break out in the Balkans, one or more of the great powers would of necessity be involved in it, and that the peace of all Europe might be endangered. This accomplished, they turned their attention to what issues were believed to be of vital importance to them all. From their discussions there emerged the fact that unity of action could be secured only by a self-denying ordinance, and accordingly they agreed one and all that no one of them should make any effort to increase its territorial possessions in any part of the world. ${ }^{1}$ To both of the inevitable questions, questions without a satisfactory settlement of which agreement among all six was impossible, reference has frequently been made, namely, to the creation of a new minor state, Albania, and to the disposition of the Ægean Islands. In no uncertain tones they gave the warring powers to understand that Constantinople, the Straits, and Asiatic Turkey were not to be involved in the field

\footnotetext{
1The world does move. The reader will note in this a temper utterly different from that displayed at Berlin in $\mathbf{1 8 7 8}$.
} 
of operations; in other words, that whatever the outcome of the war, and however diminished her European possessions might be, there was to be at the close a Turkey in Europe that should be the seat of power for the head of Islam ruling as caliph in the spiritual affairs of all Mohammedans, and as secular prince over the lands of Asia where a majority of the population were Turks.

It is extremely difficult to bring into being a nationality which probably never existed, and would not Creating a Nation now be in existence except for the exigencies of European politics. It was, therefore, the main work of the negotiators at London to secure unanimity as to the boundary lines of an Albania which was to be not merely a geographical expression, but an administrative district sharply delimited without much reference to what types of nationality composed its population. Perplexing in itself, this question was further complicated by that of emancipating Servia from the economic tyranny of her neighbors by securing to her commerce free access to the Adriatic. This agreement was finally, in outline at least, substantially as follows:

Albanian boundaries were to be fixed partly by the ambassadors themselves and partly by an international commission of inquiry studying on the spot the ethnographic frontiers. This work has been accomplished, and a suggestion has been made for that portion of their labors which relates to the south and southeastern frontier, where a district of about fifteen thousand square miles is, according to their proposition, to be divided between Albania and Greece. The new state, when delimited by surveyors, will have about eight hundred and forty thousand inhabitants. Its area 
under the Ottoman empire, was divided into thirty-one kazas, or administrative districts, in ten of which there was no semblance of any Turkish control whatsoever. The wild clansmen of these last paid no taxes, regarded no laws, kept the peace as they were disposed, and practiced the vendetta to an extent more shocking than anywhere else in the world. As soon as the boundaries were fixed, another international commission was at once established to take over, temporarily at least, the control of this strange people, heterogeneous in habits and religion, by means of a constabulary under officers chosen from some neutral power, as Sweden, Belgium, or Holland. Their procedure had, of course, to be determined by circumstances, and so far their success has been slight, the real power in the Albanian valleys being apparently that of Essad. Yet they hope to renew a truce which is fondly believed already to exist among the tribes; to pay all the bloodmoney considered due by the various parties; to close each tribal area to the males of any other tribe which may at the moment be "owing blood"; thus to terminate all existing feuds, and then to provide the funds necessary for the restoration of agriculture and trade. Such a system is far from giving even a complete autonomy to Albania, but it is intended that when order shall have been restored, the great powers shall fix upon his throne the prince they have selected, promulgate a constitution, and inaugurate a government; this would provide a semi-autonomy which is likely, considering the feeling of the population, to have a closer relation to the monarchy at Constantinople than to any other.

Such artificial state-making, considered in itself, is not an impressive spectacle, but whatever the future 
has in store, for the time being at least, this agreement and this procedure have had the dignity-yes, even the glory- of preserving the peace of Europe outside the Balkan peninsula.

As regards the Egean Islands, the situation is, in some respects, quite as perplexing. Their inhabitants The Egean are in overwhelming majority Romaic-that is, Greek, in the current use of the word. If the doctrine of nationality, which has been proclaimed from the housetop until the whole heart is sick, were to determine their fate, they would, one and all, be incorporated into the kingdom of the Hellenes; but some of them are the most important strategic positions of the East, commanding, as they do, the entrance to the Straits. A Turkey which could not control the Straits would be an absurdity. Others of the islands, as we have elsewhere stated, are so close to the shores of Asia Minor that to all intents and purposes they are Asiatic, and not European. The possession of them by another power would menace the existence of Turkish rule on the mainland. Certain of these islands, again, are held in pawn by the Italians, who seized them during their war with Turkey, ostensibly for purposes of negotiation, quite possibly, however, under pressure from the great numbers of Italians resident in the Levant, who dreamed that somehow and at some time Italian influence might be restored where once it was dominant. By the treaty negotiated at Lausanne, between Turkey and Italy, these islands are to be restored to Turkish control as soon as Turkish military power disappears from the Cyrenaica. Thus far, either of set purpose or for lack of transportation, the Cyrenaica has not been completely and literally evacuated, and consequently the islands held by Italy have not been restored, though 
Turkey has disavowed and placed "hors cadres" the officers remaining in Tripoli.

In spite of all the difficulties thus indicated, an agreement has nevertheless been reached among the great powers. The principle has been formulated and solemnly accepted that the fate of all the islands, even those temporarily occupied by Italy, is a matter not of dual but general international concern; that the great powers must settle the question eventually, and that no one of them is to retain one of these islands for itself. This, although not so momentous a conclusion as that concerning Albania, is proof of good faith and harmonious agreement among all the Six Powers. Time alone will determine the strength of this agreement, but for the present the guardianship of the islands and their ultimate disposal are the affairs of the European concert. Justice is likely to be done in the end.

Dividing the Spoil, or Treaties of London and Bucharest

It cannot be denied that a certain nervousness still exists. The treaty of London was supposed to have laid down the broad lines for the distribution of the huge territorial booty which the Balkan federation had wrested from Turkey. Quite the most important of its determinations was that of fixing the western boundary of Turkey in Europe; it selected what was known as the Enos-Midia line. Within the space of a few days, weeks at most, the federation was dissolved, the parties to it were engaged in desperate warfare with each other, and Turkey, which had been on the defensive behind the Chataldja lines, was advancing to the reconquest of her sacred city, Adrianople. Rumania was invading Bulgaria in order to "correct her frontier," that is, to secure some compensation in the Balkan settlement for the gains 


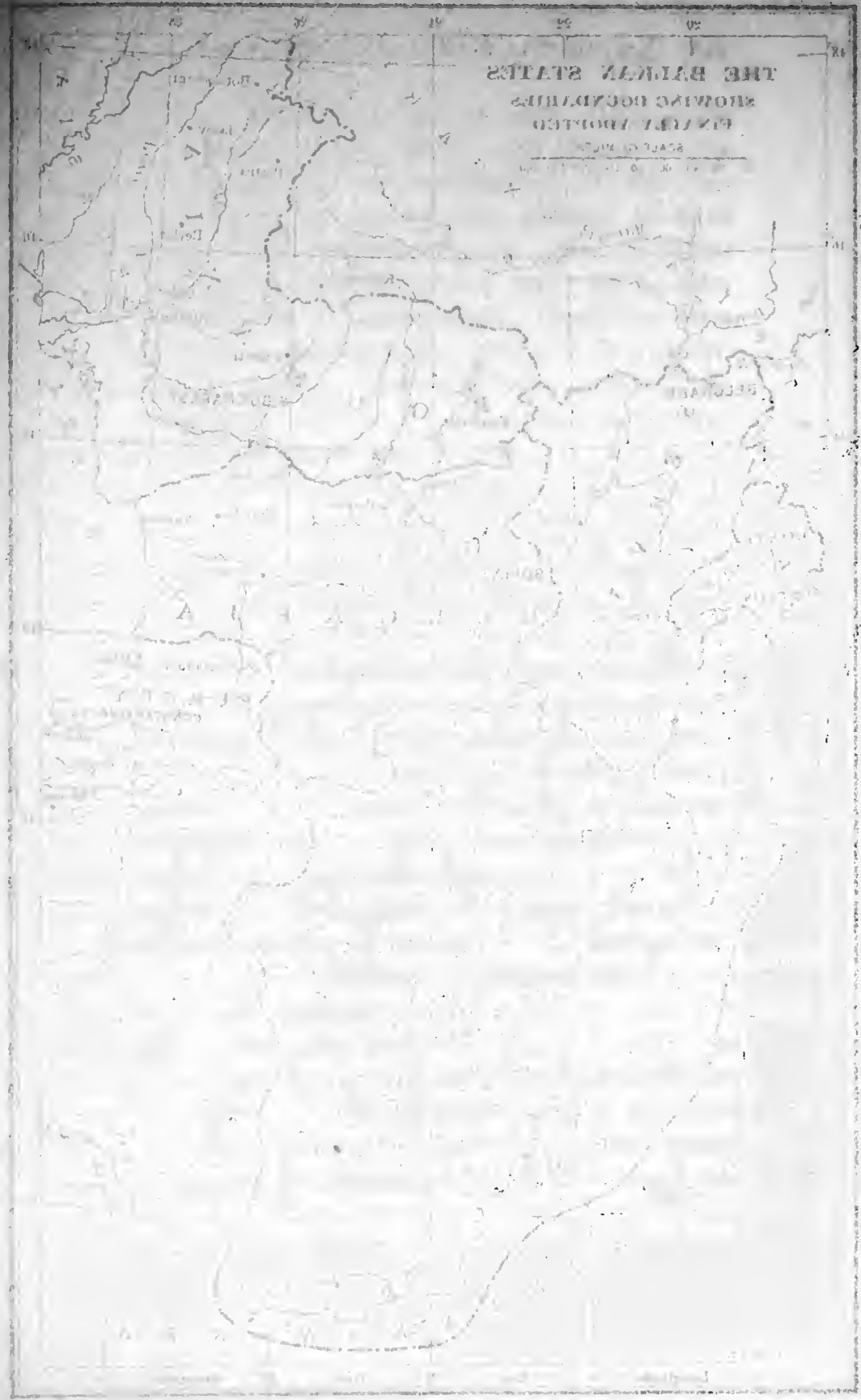




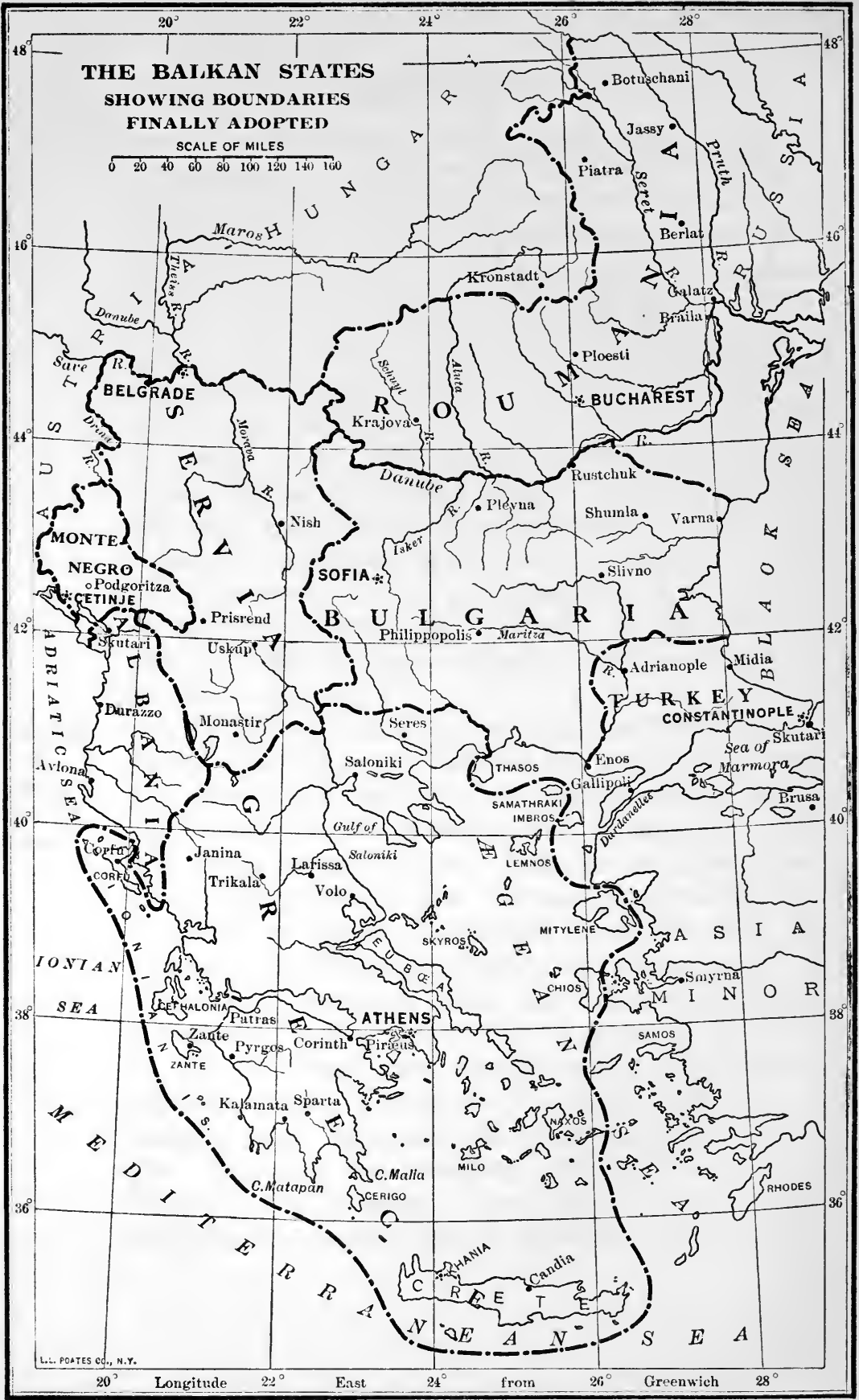


of the three other Christian powers. Macedonia was again soaked with blood, and Thrace was devastated almost to the extinction of her resources, by those very powers who claimed to have been fighting for the regeneration of both. Recrimination is perfectly futile; how the treaty of London came to be violated is unimportant. Hostilities were now over and a second treaty, that of Bucharest, negotiated in August, was concluded among the Balkan kingdoms, while still a third ffas been negotiated between Bulgaria and Turkey. The original intentions expressed in the treaty of London have been largely set aside in order that what the Balkan powers consider best may be the basis for what at most is only an armed truce. Perhaps it will be more enduring than one based upon the treaty of London or even upon the treaty of Bucharest. The substance of the present agreement is a shifting of the Turkish boundary to the north and west of the EnosMidia line and giving it such a spinal curvature that it retains for Turkey Adrianople and Kirk-Kilisseh; Bulgaria, which, in the pride of conquest, had occupied and hoped to retain by far the largest portion of the conquered territory, is permitted to retain a little triangle on the Black Sea, and an area of about five thousand square miles in western Thrace with access to the Ægean. The substantive gains, gains of the very first importance in the expansion of power and territory, have been made by Servia and Greece. The facility with which in the very latest negotiations Bulgaria has yielded one by one all the towns which were the scenes of her military glory to Turkish pretensions is a very dangerous symptom indeed. Her people are not a prey to discouragement, nor are they 
dazed by the strokes of misfortune. They abide the hour, distant perhaps, but sure to strike, when they return to the struggle not only for national aggrandizement but for revenge.

Nationality in the Treaty, or in the Balkans

The treaty of Bucharest was criticized sharply and declared to be unworkable because it paid little or no attention to the much vaunted doctrine of nationality. Should the reader have an opportunity to consult Kiepert's or any good ethnographic map of the Balkans, he will perceive that the distribution of so-called nationalities is such that scattered groups of one lie upon a fairly solid background of another; that the lines of demarcation, even where they are continuous, are so contorted as to make anything like reasonable frontiers on that basis out of the question and impossible. It is my own firm conviction that national assertiveness, that institutional differences, even that traditions, are almost entirely artificial in the Balkans and the work of paid agents faithfully serving dynasties or governments whose interest it is to divide and rule. The press campaigns of the last few years have been very skillfully conducted, and leave one to imagine the still greater skill with which agitations on the spot are carried on. It has been reiterated until we believe it, that the Christian population of Thrace is almost entirely Greek, and that under Bulgarian rule the cruelties have been even more horrid than they were under Turkish control. But a letter has been recently published from a trustworthy witness, riding from town to town, and from village to village throughout eastern Thrace but westward of the EnosMidia line. Most of these villages are smoldering heaps of embers, the Turks having burned them in their retreat. The surviving Christians he found 
assembled in Demotika, Kirk-Kilisseh, Lule-Burgas, Bunar Hissar, and similar places. For the most part he lodged with Greeks. He heard no complaints and saw no sign of ill-treatment. The populationsGreeks, Armenians, Bulgarians, and Jews-lived peacefully together on the best of terms. The Greek shopkeepers charged exorbitant prices for their wares, but they were honestly paid by the Bulgarian troops. Racial and religious tolerance characterized the occupation by Bulgarians of the country. There were even left behind a few Turks who seemed to have no cause whatever for complaint.

The term "nationality" in the Balkan States is, as there used, a word almost meaningless to us, and the word "ethnographic" is scarcely less so. In earlier pages we were at some pains to describe the processes of trituration, commingling, and almost hydraulic pressure, whereby the oldest nationalities had vanished under Turkish rule. At this hour the most patriotic Greeks bear Slavic names; but language, as we know, is no criterion, for the Bulgars are not Slavs. Another careful traveler, a long resident in the Balkans, published an indignant letter when King Ferdinand proclaimed the city of Monastir to be a part of unredeemed Bulgaria. Basing his indignation upon statistics taken by himself, he strove to show that barely one half of the population were even constructively Bulgarians. In another connection we have endeavored to exhibit on the best of testimony the state of things in Macedonia as one which renders absurd and ridiculous any claim throughout that land to any nationality, except that to the sorely degraded one of Macedonian.

Every visitor to the Balkan States would admit that 
at the respective capitals and in the districts which surround them there are sufficient differences to constitute something like a recognizable nationality: such differences as, for instance, would be perfectly manifest to a traveler, passing by rail from Stuttgart to Bern, between the Germans of Wurtemberg and Switzerland. The German of Berlin is not the German of Munich, nor the German of Munich the German of Stuttgart, nor of Bern; but they are all alike Germans. In the case of the Bernese, there is a perfectly manifest pride in a nationality which is alike German, French, and Italian. In the same way the Alsatian of Strassburg, German by blood, in language and even, to a high degree, in institutions and laws, shows the effect of the two centuries of French rule and influence. Such considerations, although all comparisons halt, nevertheless throw some light upon the distinctions which can be observed as between Montenegro, Servia, and Bulgaria. Did there exist in those countries a large middle or burgher class, it is quite possible that the differences between them in speech, blood, and character, almost insignificant as they are, could be further emphasized and enlarged so as to create inchoate nationalities, as we use that word in the West; but the overwhelming majority of the people in all three, wherever they reside, are peasants; the patriotism which stirs them to frenzy is recent and highly artificial and, as one of the bits of testimony we have cited avers, when circumstances throw them together under common conditions they are conscious of little difference between themselves, instinctively feeling their brotherhood even with Greeks and Rumanians speaking widely different languages.

Such confusions are the more remarkable because 


\section{SIX POWERS AND BALKAN WARS 25 I}

the climatic variations throughout the Balkans are not such as easily transform race stocks and confound them one with the other. The process of assimilating all types of humanity goes on from year to year without rest or cessation within the boundaries of the United States. One reason is the willingness, even eagerness, with which its population yield to what may be called broadly American influences. Exactly the reverse is true in the Balkans, and the disuniting influences within the Christian lands which were once Turkish are strengthened and promoted with an iron will and an unyielding purpose, which is the motive power that really underlies all the recent commotions.

Whether these incipient states are viable or not, time alone can determine. As yet they have all the marks of turbulent youth, even of petulant childhood: their eruptive diseases are loathsome. Not one of them has hitherto exhibited a moral standard noticeably higher than that of the others. They have disregarded the treaty of London and the treaty of $\mathrm{Bu}-$ charest, and an agreement between Rumania and Bulgaria made at Saint Petersburg, and their own alliance under which they fought side by side-disregarded them all with an absence of principle most disheartening and distressing. We confess to our shame that the higher civilizations of the West have on many occasions set them a bad example, but bad example is no excuse for utter dissoluteness; especially when, as is the case with all these peoples, they profess with a fanaticism unknown in Central and Western Europe a form of Christianity, the precepts of which apparently make no impression upon behavior. Greek Christianity, like orthodox Judaism, is very largely an affair of ritualism, and it is greatly to be feared 
that the repetitions of their prayer book, the complicated functions and elaborate crossings, genuflections, and anointings are, as far as public matters go, utterly vain.

My own experiences as a traveler, I repeat, were mainly such as would endear the unsophisticated masses of these countries to any sympathetic observer of mankind. The simple lives of the peasantry, their plain living, their frank manners, their picturesque customs, their occupation in the fields, their wonderful fruit orchards, and, in Bulgaria, their boundless rose gardens which yield the priceless Attar, the sleek and comfortabe cattle, the smiling valleys-all this combines into a most pleasing composite impression. On the other hand, even the slightest acquaintance with city life appears to transform such folk into an unrecognizable product that cannot elsewhere be seen. There is no organized society in our sense of the term. The influence of woman is utterly insignificant; one strains the vision to note chivalric manners. There is a recklessness in many matters, both private and personal, a greed for place and office, an aimlessness of walk and conversation, a lounging indolence, a friction and a creaking; the town seems not a home but, in short, a perplexing melting-pot of unbridled human passion. You felt that nothing but war was needed to exhibit on the great stage of the world the barbaric, unripe genius of people playing a role to which they were not trained. It is a sad business, setting a boy to do a man's work: and correct modern warfare is the work, sorry and sad to be sure, but the work of men who are not in a state of pupilage, not amateurs, but professionals and expert.

From what we have said it seems to be manifest 
that of public opinion in the ordinary sense there is little or none in any of the Balkan States, with perhaps the possible exception of Greece, where, in connection with the so-called military revolution mentioned above, there was a very fine exhibition indeed of a sane and safe public opinion. Even in the Western world it is not easy to find the seat of public opinion. The advanced democracy of the globe has made such an effort extremely difficult, but it is not uninteresting to summarize, as far as possible, the questions which, as far as the nations are at all interested in the Balkan question, are discussed more or less on the street and in the newspapers.

The government organs of Russia have throughout Russia exhibited a rather unusual restraint in their utterances. We are left in doubt whether there is any definite opinion at Saint Petersburg as to whether Russia has gained or lost in prestige and moral power by the temporary settlement as far as it has been reached. Her special protégés were Bulgaria and Montenegro; although, of course, she feels herself in a very high sense the patron and protector of the Greek Church in general, and of its Slavic members in particular. Montenegro has made very trifling gains in the settlement and feels herself profoundly humiliated because compelled to abandon Scutari and look on while it becomes the capital city of a people naturally hostile, and that, too, at a distance of only a few miles on the great inland lake which she had proposed to make entirely her own, as it already is in part. Bulgaria feels herself in a position of intolerable humiliation, and whatever may have been the relations between Sophia and Saint Petersburg, Rumania appears to have established more advantageous ones, securing, as

Public

Opinion as to Balkan Situation

\section{reng}


she has, a substantial and valuable addition to her territories apparently with Russia's assent. Then, furthermore, there is a curious crossing of purposes between Paris and Saint Petersburg, firm allies as France and Russia are. In pretension to Byzantine leadership, Greece is the avowed rival of Russia, yet nevertheless the moral support of France throughout the struggle has been given to Greece and in the felicitations over the event of the war, the newspapers of Athens and of Paris have vied with each other in such compliments and mutual congratulations as are familiar and usual in the intercourse of Mediterranean peoples. Exactly how much they mean is difficult for others to understand.

AustriaHungary

Iteration and reiteration are necessary to enforce at a distance the fact of extreme tension all along the frontier line between Slavs and Germans. Even the avowed pacifist would be considerate and thoughtful if he realized that Germany and the German peoples in the widest sense believe themselves engaged in a never-ending struggle for the supremacy of a higher over a lower civilization. The German empire is on the whole so loyal to its various state governments, so intelligent in its apprehension of historical problems, and so enormously powerful in its armaments that its feeling in regard to its eastern neighbor is, though somewhat apprehensive, generally one of calm assurance. The case is far otherwise with the dual monarchy of Austria-Hungary. Its only bond of union is the staunch loyalty of strangely divergent peoples to the house of Hapsburg. In order that this personal union may find some outward expression and create political efficiency, the Hapsburg monarchy has already become, what its style indicates, dual. The 
emperor of Austria is the king of Hungary, and the relations of these two otherwise independent states are minimized almost to the point of breaking. The figures of the Slavic populations in this dual monarchy have elsewhere been given. They are proportionately so large that an imperious demand is now heard for a federate Slavic monarchy within the limits of the existing monarchy, at least as independent and autonomous as the Hungarian-united with Austria and Hungary only by a common sovereign and a common control of finance and military service in so far as they affect foreign relations. These Austro-Hungarian Slavs, especially in Croatia and Dalmatia, have shown a very disturbing sympathy with the aspirations of Servia. The reigning house of the monarchy is German. The most populous city, Vienna, is German. The powerful aristocracy which is the bulwark of the Hapsbung throne is in the main German, although the magnates of Hungary are not one whit less loyal, nor inferior in wealth to those of German Austria. Whether or not the German power in the monarchy can maintain itself is a very serious question. For long periods paramount and haughty, it has been humiliated at least into an equality with that of the other elements, and many think its force is steadily diminishing. Within their own boundaries the Austro-German men of power and influence are strangely reticent. Without them, in traveling, they express without reserve a sense of the most profound discouragement. It is no exaggeration to say that millions of German Austrians desire incorporation with the German empire.

Were it not for the moral support of Germany, Austria-Hungary would be forced to play a very in- 
ferior role in the affairs of the Hither East. With it, she has made a bold stand, exhibited a brave front, and secured enough throughout the conduct of the war to save her face and enhance somewhat her prestige. The relations of the dual monarchy with the German empire were for a time less warm than usual, even chilly. The Austro-Hungarians expected stronger support in their Adriatic politics. But the friendship has again improved, as the results grow more discernible. Albania has been created, Dalmatian and Croatian discontents have been suppressed, and the Slavic movement generally appears to have made losses rather than gains, especially since the finest branch of the Slav Austrians, the Bohemians, have made such sorry work of the finances intrusted to their charge, and have bankrupted their so-called kingdom in part, and its great capital of Prague almost completely.

Servia

Whence has come the moral and financial support of Servia remains mysterious. Of all the Slavic peoples the Servians have so far been personally and publicly the most improvident. Servian banking is little more than pawnbroking. There has recently been published by a Frenchman, resident for many years in Servia and conversant with Servian affairs from long participation in them, a very valuable study, one item of which throws a strange light upon the recklessness of the people. It has degenerated, as far as the government is concerned, largely into a police state. The Servian burgher finds his chief occupation, therefore, not in politics, not in commencial and industrial enterprises of stability, but in discounting the future. The writer gives the single instance of a bank in the important city of Nisch which was founded some five years ago by two partners with a capital of 
six hundred dollars. With that security they borrowed about half as much more and opened their doors to lend money at twelve per cent discount. They soon capitalized the institution at one hundred thousand dollars. Of these shares half are retained in the treasury and half have been bought by the public. The bank owns a handsome countinghouse, and its business expands by leaps and bounds. Every borrower that has desired a loan of one hundred dollars gave his note, properly indorsed by some friend, as security. He then received seventy dollars in cash and thinty dollars in stock, the par value of the shares being ten dollars. As our author remarks, this is far from a solitary instance; the passion for borrowing is a cancer which slowly eats out the vitals of the Servian organism. These and similar charges have never been denied, and with such a temper and such slack habits of finance it is quite possible that some portion of the national loans were easily negotiated among Servians themselves. But even if this were so, what could be so raised would be utterly insufficient, and there must have been a system of borrowing in other lands which has not been generally known to the public. Every wild guess has been made: that there was actually a secret understanding between the bankers of Constantinople and Belgrade, that the ever-vigilant Russia secretly provided funds, that ammunition and guns were secured on credit-in short, nothing seems too monstrous for the gullibility of yellow journalism. The plain fact is that we know nothing and can express only amazement at Servia's achievements. Long hence it will doubtless appear that Turkey and the Young Turks were diplomatically fishing in troubled waters from beginning to end at 
Belgrade, as well as in other Balkan capitals, eating the bread of humility secretly in their desperate efforts to retain the semblance of the Turkish empire. Even superficial observers suspect that these struggles produced some effect in Rumania.

Whoever was the backer of Servia, it assuredly was no one hostile to Austria-Hungary. The western frontier of Servia has not advanced an inch and it is even yet uncertain how she is to be given the promised commercial access to the Adriatic. That important portion of the Mediterranean is still controlled by Austria-Hungary and Italy. Italy too, as we recall, still occupies the islands in the Ægean, which she has held as a guarantee for the treaty of Lausanne.

Italy

This, of course, gives Italy an advantageous position from which to negotiate, especially if the border skirmishes between Servia and Albania develop into more important warfare; or even if Servia, stimulated by Turkey's successful recalcitrancy, should attempt to secure a boundary including certain small districts it claimed alike at London and at Bucharest, but which were not yielded to her. In the general belligerency of the last years Italy has gained much. It is not merely that she has secured a substantial portion of the north African shore lands. She has consolidated her nationality and exhibited its power in such a way as to command respect from the other five great powers.

Germany

The German empire has seized the occasion enormously to strengthen its military forces by land and sea. Probably the whole world better understands this policy in consequence of the Balkan wars; certainly Germany herself has secured a clear vision of the fact that the most serious menace to her civiliza- 
tion lies along her eastern frontier. Not that she is warlike in the sense of seeking a quarrel. The great warlord has proven himself for twenty-five years to be the great peacelord of the European world. It is not the tradition of the Hohenzollerns to expand for the sake of expansion, but it has been throughout the long and not entirely inglorious history of the family their unbroken effort to consolidate German lands and German populations for German welfare; to defend what has been won; to create a majestic organism; and to assert the place of Germany among the great reciprocal forces, the powerful interacting influences of the modern world. We have no reason to believe that there has been any change in this impressive policy. This seems more probable in proportion as the barbaric and atrocious excesses of Slavs have exposed in glaring exactness not so much what they desire the warfare to be in which they engage, as what with their temperament and nature it necessarily must be. The German empire has been absolutely loyal to the self-denying ordinance passed when the representatives of the Six Powers first met at London.

If Germany was, as she was, well aware that her France resources must be husbanded as a bulwark against uncertain conditions and impending menace to the eastward, France, with the brilliant galaxy of statesmen now controlling her destinies, was equally impressed with her own enormous task in reducing Morocco to even partial subjection and consolidating a colonial empire which, in the forty-odd years since the Franco-Prussian War, has become so vast as to be unwieldy, being a source of enormous expense to the home government and producing, at least as yet, scanty returns for the national treasury. She, too, has 
been entirely loyal to her earliest engagements; but, believing herself by tradition and sympathy deeply concerned in the progress of Greece, she has not hesitated to cheer on that nation, to rejoice in its victories and to take great satisfaction in the evidences of self-restrained power which it has furnished to the world.

Great Britain

But, after all, the most majestic organization throughout the events we are considering has been that of Great Britain. It was the host of the ambassadors' conference, and likewise of the Balkan plenipotentiaries; and it was fortunate in having as foreign minister Sir Edward Grey, a man of sound understanding, of strong convictions, of thorough knowledge, of versatile capacity, who, throughout his guidance of those difficult negotiations carried on in London, enjoyed not only the undivided support of his own party, but also a generous abstinence from obstruction on the part of the Conservatives. It may be said that he commanded the confidence and had the backing of the British nation and empire undivided; and that likewise in a high degree his was the leading part in the councils of all Europe. The England which gave him unstinted approval was not the England which in 1878 had seized Cyprus and occupied Egypt. There was no thought of territorial aggrandizement at the expense of any other people. For that reason the utterances of the government at Westminster were doubly weighty. They have been characterized by the confidence and sobriety which arise only from fixed determinations and readiness for action. This accounts for the ever-growing influence of the British ambassador at Constantinople, for the rather strange but admirable attitude of Berlin 
which put an advanced German liberal, Prince Lichtnowsky, as successor to Marshall von Bieberstein at the Court of Saint James, and indicated a willingness for cooperation that must be considered magnanimous in view of the dazed and almost hypnotic suspicions which the British had so long entertained regarding German policy.

Great weight, therefore, may be placed upon the declarations of Sir Edward Grey. His voice may be considered almost, if not entirely, to express European sentiment. In order, therefore, to grasp the effects of the Balkan wars upon Europe at large, we may safely rely upon some of his most important authoritative and official public statements. In no uncertain tones he utters a solemn warning to Turkey in which he says, "That her failure to accept the advice of the Powers as regards her western frontier is almost sure to bring on the Turkish government disastrous consequences, either in the shape of financial distress or of armed intervention from which no one can defend her." The one essential feature of her new western boundary must be, he declared, that the line should possess strategic strength. ${ }^{1}$

As to Mohammedan powers in general, Great Britain will in the future, as in the past, assume for itself the assurance that the "rational sentiments and religious feelings of Mohammedan subjects within her dominions shall be respected and have full scope." As a corollary to this, Great Britain can be neither intolerant nor aggressive regarding any Mussulman power. "But under no circumstances could we protect Mohammedan powers, as such, from the consequences of their own behavior." "To suppose that

1The delimitation as arranged at Constantinople appears exactly the opposite. 
Will Wild Europe Hear and Heed? we can undertake the protection of, and are bound to regulate our European policy so as to side with a Mussulman power when that Mussulman power rejects the advice given to it-that is not a claim which we can admit."

As to the question of intervention, he has on several occasions made the very trenchant remark that any other than armed intervention would be impossible, and that to go to war for the sake of preventing war is an absurdity and a contradiction in terms.

All these are brief and weighty utterances, yet they have not entirely dispelled nervousness or distrust. Procrastination is the essential vice of the Orient. The lapse of time creates new interests and new currents of feeling. Wild Europe has long heard the admonition of civilized Europe given with great show of importance and empty emphasis to Turkey. Throughout generations these instructions have been utterly disregarded and secretly ridiculed. When, now, the admonitions of the great powers are addressed no longer to Mohammedans, but to professing Christians, the question naturally rises, Do they signify anything more than before? Already the new masters of the Balkan peninsula have given an example of their intolerance and fanaticism in the treatment of western missionaries at Avlona. America is far away, as distance is reckoned, from all the scenes of Balkan horrors. American travelers are for the most part utterly ignorant of the language, institutions, and temper of the Balkan peoples. We have not, therefore, from lack of data, profoundly considered hitherto the effect upon American interests, either religious, industrial, or commercial, of the expulsion of the Turks and the annihilation of Turkish rule in 


\section{SIX POWERS AND BALKAN WARS 263}

those parts of the world, but, dispassionately considered, every one of them is more endangered every hour.

Peering into the future through the smoke of incendiarism, with senses blunted by the cries of the helpless, the moans of the wounded, and the awful sights of mutilated corpses, of crippled and disfigured survivors, the man would be rash indeed who would venture upon prediction. Yet America has long had peace upon her own frontiers; her experiences were for a generation utterly foreign to any like those which have molested the safety and health, moral or physical, of European nations. But with the Spanish War all was changed. While comparisons are dangerous, yet, judging from that conflict, and from the history of Mexico, there appears to be probable and possible for the western powers of Europe only one final outcome in the Balkan States; perhaps also for us, in the settlement of intolerable conditions between our frontier and the canal strip. Already we have seen in those lands what began as an ordered warfare degenerate into brutal, reckless, and guerilla conflicts. We have seen a war of enfranchisement quickly transformed into a war of conquest, and then into a struggle without quarter, a conflict of life and death for the extermination of one and measurably both combatants. We have seen lands, already ravaged, devastated, and delivered to a desert solitude, plowed once more with bullets and bayonets and harrowed by the small arms of ghoulish banditti. We have seen great districts abandoned and their few surviving inhabitants huddled in squalor and famine behind the fortifications thrown up to defend towns. Finally, we have seen the barbarous perpetrators of 
all these outrages frankly and shamelessly confessing the misery, the famine, the hunger, and the thirst among their victims, those who were weak and helpless to combat the vain ambitions and mad passions of their leaders. On the other hand we have seen malefactors high in place denying their deeds and holding out their hands with prayers for assistance to alleviate the misery they have wrought. All our hearts are wrung and our purses will be opened and our charities will be abundant, but whatever can be done in this way can be but temporary. In the long run, there as here, it seems as if nothing short of absolue exhaustion, an exhaustion which is not far distant, could secure a remedy of any efficiency for such shocking social diseases. Hat in hand, the wild peoples of both Europe and America will have to make a piteous plea for peaceful intervention. Utterly incapable of self-restraint and of self-government, they will have to ask for the restoration of order under foreign leaders; for a well-organized constabulary under officers who can command obedience and exercise some degree of control until the rod of correction has done its work and made the memory of punishment a wholesome, permanent preventive for passionate excess.

Islam in the Balkans

According to the latest authorities, there are still left in the Balkans two million Moslems, of whom it is reckoned that at least a million are Turks. Had Bulgaria been able to make good her earliest claims, there would have been within her boundary about one half a million of these "aliens." The principal city of Bosnia is Sarayevo. At the present hour it is a curious conglomeration of a modern and somewhat impressive German city along with a half-regenerated Turkish town. There are impor- 
tant Roman Catholic churches, a very stately Greek church, and a number of mosques, one of which, the Husref-Bey, is large and impressive, dating from the sixteenth century. It was with the utmost difficulty that I got into anything like friendly relations with its chief administrator, who suspected that, after all asseverations to the contrary, his visitor was but an Austrian emissary. Some pertinacity, and the exhibition of a slight familiarity with the Koran, finally, however, rendered him communicative. He said that the Moslems of Bosnia were, on the whole, fairly content ; that their institutions, religious life, and traditions received kindly consideration from the Austrian authorities. It may be well to interject here that the onetime Turkish provinces of the Herzegovina and Bosnia are a joint possession, belonging neither to Hungary nor to Austria, but administered from Vienna in the interests of both-an undivided imperial domain of the Austro-Hungarian monarchy. Under the tolerant rule which they enjoy, these Slavic Mohammedans have a local government, liberty of the press and of speech, fair representation, and make no complaints of undue restriction or persecution of any form. Their kindly treatment by Austria-Hungary is, of course, well known to all Moslems in Europe, and probably for that reason those who live within the boundaries of the native Christian states expect in the final settlement a "modus vivendi" for themselves similar to that which their coreligionists enjoy in the districts already under Christian rule. Montenegro likewise practices a broad and kindly tolerance in dealing with her few Albanian subjects of the Mohammedan faith.

There is nothing about which Europeans differ 
more than about the character of the comparatively few Turks still remaining to the west of the Bosporus and the Straits. Many indulge in unmeasured encomiums, while others find no language in which to describe their backwardness and worthlessness. Apparently, this is due to two causes: first, the degree in which the so-called Turks of certain localities have intermingled with Christians and the character of the Christians with whom they have intermingled; in the second place, to the temperament and disposition of the observer. Probably the numbers of really pure Turks now in existence might be measured in terms of five figures; the rest are the descendants of men who carried away as captives great numbers-some think millions-of Christian women, who, immured in harems, were the mothers of vast numbers who consider themselves Turks and possess the Turkish type. The many Christian families which, male and female, became Moslems in order to escape the devastations of the Turkish soldiery centuries ago, intermarried, moreover, with the conquering hordes. The result of these admixtures of Christian blood is by many believed to have a determinative character in the various types of Turks found in different places. An eyewitness in the valley of Asia Minor watered by the river Pactolus, has assured me that the thousands of fugitives from Europe taking refuge in that district are people of a delightful character, industrious, thrifty, responsive to kind treatment and to discipline; the horrible mutilations inflicted upon them by the soldiery of the Christian powers in Europe they endure with patience and fortitude. By their frank, pleasant, democratic spirit of mutual self-help they recommend themselves most highly to Euro- 


\section{SIX POWERS AND BALKAN WARS 267}

peans. They are excellent excavators in the splendid American enterprise at Sardis, they are indispensable in the harvest fields, they are fond of their little gardens, of running waters, of nature in her gentle moods, and even of poetry. Among them Professor Littmann, of Strassburg, a most distinguished German Orientalist, has discovered a considerable proportion who speak a Turkish language fairly pure, and who are sufficiently intelligent to give thrilling accounts of their sufferings at the hands of komitadjis in Thrace and Macedonia.

The descriptions already given of Turkish settle- Islam in Asia ments in Europe apply with double force to their towns and homes in Asia. The houses, for the most part frame, covered and lined with wood, are kept in no repair. The streets reek with filth. The only scavengers are the half-wild dogs who, because of their usefulness, enjoy a strange immunity and license. The bazaars deal in such wares as would commend themselves to only the humblest dwellers in Western cities-cheap fabrics, worthless knickknacks, and a few commodities for the support of life. There is some exhibition from time to time, and spasmodically, of energy and enterprise, but it is shown almost entirely by Greeks and Jews, or a few European Slavs. Their agriculture is in a deplorable state of backwardness, their forests have been so ravaged that the rainfall is untrustworthy and their water supply for the raising of stock or for irrigation insufficient.

There are a few railway lines in Asia Minor-one, owned by Germans, running from Scutari, opposite Constantinople, on to Konia (the ancient Iconium), which is in the process of extension to Bagdad and 
possibly further. From one of its stations, about half way on the total length of the line, there starts a branch, built and controlled by the French, which runs to Smyrna. There is also a railway from Magnesia to Pandora, on the Sea of Marmora, and finally the English have built and manage a line eastward from Smyrna through Ephesus, which will eventually connect with the German system. The best authorities affirm that these railways have in no way changed the character of the districts through which they run; that there is no revival of enterprise or trade and no increase of population in consequence of them. The manufacture of opium has come almost to a standstill because of the restrictions upon its sale. As is well known, considerable numbers of Turks, Syrians, and Asiatic Greeks have emigrated to the United States in recent years. A small proportion of them have returned to their native seats and exhibit on their own shores in Asia, in some slight degree, the enterprise which they have had awakened here. American mission stations are scattered here and there and make some headway against the dullness, apathy, and ignorance of the populations round about.

The purpose of such remarks about Asia Minor is to indicate why the Turkish armies, about which much has been said, proved the broken reed which they were and are. Because of the character of those who were drafted into their ranks they had no endurance. Quite contrary to the facts is the widespread error which imagines the existence of Turkish populations

- in Asia from which efficient recruits can be drawn. There is no source of supply among the Turks in Asia from which the armies fighting about Constantinople and along the Thracian or Macedonian coasts 
can be adequately recruited. The Turkish empire, as it will be in fact, may be an empire maintained by European diplomacy. But shorn of its European possessions, it will be a rickety structure, destitute of the props and stays upon which it has hitherto rested; capable of regeneration only by administration through gendarmerie and constabulary composed perhaps of natives but officered and disciplined by trained soldiers from Western lands.

Something has already been said about the spirit of absolute equality which permeates Mohammedanism, about the entire absence of rank and caste in worship, society, or trade. Not only is this characteristic of the cult itself, and of all who devoutly practice it, but it is especially and peculiarly a Turkish quality. Even when the rank and file of the Turkish army submitted to discipline and suffered itself to be drilled and trained, when there was a semblance of organization and fighting spirit, there were no fixed distinctions of rank between officers and men. The officers were exactly like the men themselves; they commanded obedience only because of expediency, much as the preachers and administrators of the mosques secure a semblance of order and enjoy some respect because of their native ability. It is credibly said that during the recent wars the Turks confronting. the Hellenic troops had no conception of how to handle the splendid cannons, guns, and war munitions which they had purchased in great quantities; and that their first experience in making use of them was the sorry, awkward bustling of stolid dreamers when brought to some realizing sense of danger by the whistling of Greek shells and the rattling of Greek machine guns. Whatever prestige 
the Turks of a generation ago gained at Plevna has been utterly dispelled; even the tenacity with which they held Adrianople and the smart return to the Maritza valley after the disarmament of Bulgaria cannot restore it. 


\section{$\mathrm{X}$}

\section{HOPES AND FEARS}





\section{$\mathbf{X}$}

\section{HOPES AND FEARS}

THE peace movement has in recent years assumed dimensions which half a century ago would have The Peace been considered utterly utopian. Indeed, it has gone so far that its advocates have themselves become moral challengers and wordy combatants. They have stigmatized as not merely brutal but as utterly uncivilized all display of force and every settlement of international difficulties except that of reference to courts. To them all questions of international relations have become alike legal and justiciable. Moved by unquestionable zeal and supplied with ample funds, their tracts flutter into our countinghouses and workrooms, on the wings of every mail delivery. They denounce all armaments and find no other safeguard for the amity of nations than in the virtues which so far have been those of a highly trained and sternly disciplined personality. The analogy between individuals and organized society is so attractive that it has been extended to cover the entire field of social activities. We are almost persuaded that there is a national conscience in the same sense in which there is a personal one. It is a brilliant and shining goal, for which all men of good will and high principle must ever strive. Yet the virtue of self-restraint is rare in natural persons, and, even in them, easily degenerates into pusillanimity.

Many of our worthy pacifists have suffered pro- 
Encouraging found discouragement in the contemporary history Facts

Common

Origins in the Balkans

of Eastern Europe, but there are, nevertheless, reasons for great encouragement, not to say for elation, when we consider the course of events during a half century. We must be struck by the fact that for over forty years there have been no armed conflicts between the really advanced nations, and that throughout a period of nearly two years, rife with possible reasons for disagreement; yes, even for considering and offensively upholding the point of honor between them, they have not merely made self-denying agreements, but have likewise observed them with a conscientious faithfulness hitherto unknown in international dealings. They have shown not merely a fine self-restraint, but they have exhibited a patience regarding their unruly wards which has afforded a superb example alike to the contestants in the Balkan wars themselves, to us, and to our posterity.

Enough has been said in the previous chapters to indicate how uncertain is the so-called nationality of the Balkan States. When we ask ourselves in this day and generation what is requisite for the constitution of a nation we are sorely puzzled to find any satisfactory answer. We know that all the old ideas have been relegated to the chambers of memory. There are powerful and, in a sense, homogeneous states which have no singleness of origin, whose citizens are not descended from a common ancestry, and who have no common unity of tradition. Indeed, the passion for expansion has produced strong and vigorous nations which are the most amazing congeries of unrelated parts, all living harmoniously under single central governments. In these nations there is no unity of speech, for struggles to secure the use of one 
language by all their citizens prove to be a source of friction and difficulty; or, even worse, a cause of dangerous disunion and revolt. Nor is there in contemporary national lives any true unity or equality in institutions and the administration of the laws. With knowledge more or less imperfect of such undisputed facts, there is in Eastern Europe a great race stock which does possess some consciousness of common origin and is nevertheless divided hopelessly into the great sections of north and south Slavs. Having made the most careful inquiries from intelligent sources, the writer is convinced that there is a unity of language among all Slavs unsuspected by the great majority, even of scholars. A Russian diplomat long in the service, and stationed for the most part in Slavic lands outside of Russia, vigorously asserted that a patient, slow-speaking, born Slav of any stock can, in conversation with any other born Slav, both understand and be understood, which is not true of the different peoples who call themselves Teutons or of those who are styled Latins. Aside from unity of origin, tradition, and speech, the Slavs have a further unity in the matter of religious faith and ecclesiastical organization.

The observer must feel a sense of dismay when, Elements of further, he beholds the south Slav portion of this Disunion great race stock, more unified in these respects than any other, embittered against the Slavic north; and itself hopelessly shattered into petty political organizations, eager to emphasize differences rather than to preserve correspondences. It is customary for those who attach a somewhat sacrosanct meaning to the word "republic" to declare these evils the result of dynastic conspiracies. Such talk is not merely 
untrue, it is stupid. Our readers will have observed that every Balkan dynasty, except that of little Montenegro and the blood-stained Obrenovitches of Servia, reigns because of agreements among the great foreign nations of Europe, and is tolerated by its subjects just in proportion as it identifies itself with their interests and what they call their patriotism. It will be only in the next generation of reigning Balkan sovereigns, if the dynasties maintain themselves so long, that the respective Balkan peoples will feel themselves to have native rulers.

The quarrels of these little states are due to a cause which lies deeper, namely, the stage of civilization which they have respectively reached. To an unsuspected degree they are still in the clan stage of government. It is not political considerations which mold their history, except in an inchoate form; with them patriotism is a matter of personal like or dislike for a leader, an affair of reciprocal interests, of enthusiasm for chieftains of some sort, for men who may be merely petty local leaders. The rare exceptions are those who possess the gifts which fascinate the multitude, the large agglomerations of local units. There are great tracts of the Balkan peninsula where still the controlling institution is that of the vendetta. It is by reason of that curse of primitive man that the king of Servia sits on his throne. There are other districts within which local government in some degree concerns itself with the welfare of all who live under its limited control. There are still others where there is something like a perception of that welfare which is common not to tens nor even hundreds but to millions of like-minded people; where there can be noted a hazy perception of real government, but where, as yet, this 
perception exercises little influence, and where the currents of what can be called only by anticipation public opinion still find their principal strength and direction in the personal guidance and interest of leaders who are not much more than tribal heroes.

It can easily be understood how embryonic were the nationalities formed by the combinations of such clan leaders and their followers. But it is a misleading analogy to draw the parallel so attractive to those concerned of the formative process whereby the nations of Central and Western Europe came into being through the combinations of various feudal units. Feudalism, although in no sense a political system, was nevertheless a very powerful and highly organized social one; and in no way comparable in its social organization to clanship.

The nationalities and states in southeastern Europe have, nevertheless, an organic germ within them, and their evolution may be much more rapid hereafter than it has been in the past. Political forces, like natural ones, have no fixed rate, and operate much more swiftly at one time than another. Certainly, Rumania, barely sixty years old, is much nearer to being a nation than Servia. During the space of more than an entire century Servia's progress toward real nationality was negligible, and it was only within these very latest years that she became conscious of national responsibility and behaved with the gravity of a people which sees its duty and contrives to do it. There is a sense in which every one of these nationalities is artificial. That of Albania is little more than a paper structure, erected on paper for the convenience of other nations. Throughout the course of history there has been no more puzzling phenomenon

Possible Advance in Nationality 
in the ineffective human laboratories of the Balkans than that presented at the present hour within the arbitrary boundaries fixed for what is heralded as a coming state. We can hardly believe that such a state will ever be more than a convenient administrative district kept together by pressure from without and ruled with no other sanction than that of unbending and stern application of foreign force.

Even if it be freely admitted as a fact that elsewhere petty local communities were perpetually flying at each other's throats throughout a long period, and that within two or three generations there has been comparative peace within their increasing bordefs, yet we have been eyewitnesses of the fact that the relations between those larger communities are no better ordered than they were between the smaller. Wild Europe has continued to be wild Europe, with the single difference that the contestants were brigands of a larger growth.

An Armed Peace

The enormous increase in military strength on the part of the south Slavs, however divided among themselves they may be, accompanied by a similar steady growth of military strength among the north Slavs, has produced the conviction in Germanic Europe that no peace on its eastern frontier is possible, except an armed peace, a peace enforced by sheer brute strength against a lower civilization which manifests its growing pains in such fierce strife as that of the last year. Americans can very easily realize the situation of both Germany and German Austria if they figure to themselves a similar neighbor upon contiguous territory in a like state of semicivilization, but able to call within a few days a well-armed, equipped, and drilled army numbered by the hundred thousand 
into the field. Throughout our history we have felt, as civilized Europe has, and have proved by action, as the European powers have latterly done, that our neighbors to the south must, if possible, be permitted to fight out their own quarrels; but we have also felt that, if necessary, they must be brought to book by armed force and compelled, under military sanctions, to cease from murder and rapine, to exercise at least so much self-discipline that orderly relations might be maintained with them. As we have remarked in another connection, the armaments of the European world have been increased to an appalling extent solely and entirely because of the menace which is believed to exist in the possible and even probable exercise of the force accumulated in the Balkans for the purpose of these latest wars. Were we their close neighbors, nothing could shake our conviction that the only peace possible was an armed one. We have previously used their own word "extermination." How near an approach to that dreadful goal has been made is displayed in the figures of a Bulgarian census taken in the first weeks of January, I9I4. In the conquered territories assigned to them the adult males numbered 702,000 before the outbreak of hostilities; at their close there remained alive only 300,501 !

The relations of European powers to each other are, of course, many sided. Throughout the duration of these wars there was, as repeatedly noted, real

Delicate Relations of the Powers unity of all the Six Great Powers to delimit the field of hostilities and confine the fighting to the territories of the combatants. But they had other and very important relations which occupied and continue to occupy the strained attention of their statesmen. The 
Triple Entente was wooing Spain; the notion of a common Mediterranean policy for those dwelling on the shores of the Mediterranean manifested itself in an imperious way, and the whole question of Mediterranean control was thrown into the forum of public debate. The interests of Great Britain in that matter have not changed and are widely different from those of France, Spain, Italy, Greece, and Russia.

Meanwhile, the Triple Alliance was regarding with complacency the better understanding and closer union between the three Scandinavian powers, and was successfully cultivating their good will. The efforts made to promote a better and milder state of feeling between Great Britain and Germany have been little short of Herculean. There have been important results, but as yet not entirely proportionate to the exertions made. The most that can be said is that on both sides hysterical and unreasoning bitterness is no longer manifested, and that the wisest and calmest public opinion in both nations regards with interest and approval every effort to create some degree of cordiality. We hear very much at this distance about the proposal for a naval holiday, that is, for a temporary cessation of the waste and extravagance involved in the rivalry for overwhelming sea power. Yet, in our enthusiasm for a suspension of war preparations, we should be reminded that in a small but important way Greece, having been successful during the Balkan wars in her naval policy, has seen her very existence as a nation once again thrown into the balance by Turkey's purchase of a dreadnought, that her prime minister, Venezelos, has made the round of the European Cabinets asking that 
they forbid the renewal by Turkey of hostilities either by land or sea; and, incidentally, that a sop may be thrown to the unreasoning exaltation of his fellow countrymen by leaving, at least for a time, Greek garrisons in the Greek towns within the lines designated as the frontier of Albania. Now, nothing could be easier than to command peace by sea between Greece and Turkey; but who shall issue the mandate, and who shall profit by commanding such a cessation of arms? Italy and Austria-Hungary, without attracting much attention, are steadily increasing their naval power with a view to just such an emergency; and the increase of existing naval power in any direction demands a general readjustment and produces a nervous uneasiness in the nations hitherto accustomed to be supreme in that regard.

Close examination of the relations between the Balkan powers and the Triple Alliance reveals sources of disturbance which, though momentarily sealed, might easily be reopened. When Austria-Hungary demanded a revision by the Six Powers of the treaty of Bucharest which distributed the spoils and was signed by representatives of all the Balkan States, except Turkey, on August 10, 1913, it was her trusted ally and bulwark, Germany, which thwarted the plan and announced its emphatic approval of the treaty. This was due to a widespread and firm conviction that Emperor William had given to his brother-inlaw, King Constantine, convincing reasons for moderation in the demands of Greece on the one side and had enforced similar considerations with his Hohenzollern relative, the king of Rumania, on the other. It was without question highly significant that in reply to the emperor's congratulatory dispatch King Carol 
of Rumania expressed thanks for services rendered. In order to soothe Austro-Hungarian susceptibilities it was necessary at a later date for the emperor to protest anew a loyal friendship for his faithful ally, Austria-Hungary.

Italy supported Austria-Hungary in her demand that Scutari be included in Albania, and this was an act of tremendous significance, because the muchloved consort of King Victor Emmanuel is the daughter of King Nicholas of Montenegro, and temperamentally a devoted patriot-a fine, public-spirited woman alike as regards the land of her birth and that of her adoption. Naturally enough, some slight jealousy of Austro-Hungarian influence in the new Albania has been felt throughout every rank of the Italian people. This uneasiness was further heightened when it was known that the excitable and mercurial population of Triest, the new queen of the Adriatic, the metropolis of "Italia Irridenta," had taken this opportunity to make anti-Italian demonstrations before the Italian consulate. How far the temper thus created is likely to influence Italy's course regarding the Egean Islands she had seized from Turkey and still holds in pawn cannot be known at the present writing, but what is thought and felt in the nervous, hypersensitive chancelleries of the European capitals is manifested in a British note to the Powers issued in the first weeks of I9I4.

Ostensibly this note was to soothe the exasperation of both Italy and Austria-Hungary regarding the south Albanian frontier and the work of the commission which was to have been completed on November 30, I9I 3 , but had been delayed for more than a month. In reality, it appears as if its weightiest paragraphs 
were those dealing with the question of the Ægean Islands held respectively by Greece and Italy. The note suggests the retention by Greece of all the islands it had occupied, except the two at the mouth of the Dardanelles, Imbros and Tenedos, always with the understanding that she fortify none of them nor make any one a naval base. It further emphasizes and repeats the categorical assurances given by the Italian government that on the conclusion of peace with Turkey it would evacuate the islands it had seized. It calls attention to the fact that while Turkey had not transported from Tripolitan soil every remnant of its army, nevertheless it had disavowed and placed "hors cadres" the officers there remaining, and that the treaty of Lausanne had thus acquired full validity. The time, therefore, is ripe for settlement. When these islands are restored to Turkey they should, according to the suggestion of the note, receive some form of autonomous government. This proposition is manifestly intended to placate all the Mediterranean powers, including Turkey and Italy. The Italians have been, during the period of their occupation, untiring in the improvement of their temporary possessions, especially in organizing and developing the resources, long untouched but considerable, which still exist in those Elysian spots, notably in Rhodes.

Inasmuch as the respective members in each of the two threefold arrangements or understandings, by whichever name they are known, sedulously and carefully watch each other in regard to the strength of their available military armaments by land or by sea, it is manifest that these semifederal unions would not be renewed from time to time as they are unless the situation were fairly satisfactory to all. Of course 
the readjustments of internal politics in each and all have much to do with their foreign affairs. By means of an elaborate diplomatic system, however, each power thoroughly understands the situation as regards every other; not merely in matters of public knowledge but, oftentimes, through their confessed system of espionage, in matters intended to be kept secret. We may reasonably conclude, therefore, that, on the whole, the existing situation is considered fairly satisfactory. The equilibrium is quite as stable as any that has existed for two generations.

"United States of Europe"

The good habit of peaceful negotiation without recourse either to force or to courts of arbitration has been crystallized so far as to give great promise for the future. The good habit of referring acute difficulties to the cool deliberations of an international court is not so well established, although promising beginnings have been made. Idealists have long discussed the possibility of a "United States of Europe." While such a federation is far from realization in the sense attached generally to the idea connoted by those words, yet lovers of peace ought to realize that, as far as the Six Powers are concerned, much has been accomplished during these recent years toward furnishing a practical and striking example of what a more perfect union would be able to do for the advancement of mankind. It is not the dream of a visionary that such an initial unstable equilibrium may become more and more stable and trustworthy as Western Europe is confronted with the difficult situation which exists in the eastern portion of that continent. It seems like a categorical imperative that the higher civilization should unite all its forces, alike for possible conflict and for the peaceful uplift 
of a great mass of humanity emerging from darkness.

In the endeavor to draw from the facts that have recently come under our observation some conclusions regarding that which we do not know, we, at least, are Some Tentative Conclusions justified in believing that should there be a new outbreak in the Balkan States during the near future, the Six Powers would again adopt the policy of patient waiting, which has proved, in spite of its patent faults, on the whole, satisfactory to all concerned. The result, of course, would be a more complete exhaustion of every one of the Balkan powers, including Turkey. At any rate, there is no longer any excuse for federation against Turkey and the renewal of hostilities on that basis. What seems much more likely is the transfer of the antiquated Occidental doctrine of "balance" from Western to southeastern Europe. This would result in creating two jealous and hostile federations for the preservation on the one side of what has already been gained by the members of one: and, on the other side, the prevention of further aggression to increase their gains by the nations who have profited, as is felt, far beyond their deserts.

It is not absurd to conceive at least of Greece and Servia, with possibly Rumania and Montenegro, forming a league to assure, by means of a long or comparatively long cessation of warfare, the consolidation of their power in the conquered territories definitely apportioned to them at Bucharest. But it is a matter of no great importance how separate understandings may be reached among the Balkan powers. It is a matter of the first importance that they have already contemplated them and that in their primitive historical laboratory the experiences and experiments of older nations 
may be tried for their purposes. Should there be formed two fairly stable federations, it would not be so utterly impossible that out of the two one should eventually arise that could be consummated in no other way. Considering the strength the Balkan powers have exhibited, and the fact that four of them proved the efficiency of federation even for so short a time, it must be finally revealed to them that only by closer and longer federation can they finally present a respectable front toward Central Europe and assert the right which they claim to determine for themselves their final destinies?

Each of these states has quite enough to do within its own frontiers to exhaust every effort they could possibly exert for thirty years to come. While Francis Joseph is the sovereign of Austria-Hungary there can be no question of division in his monarchy; not even an effective demand, as we believe, for its transformation from a dual to a triple one, having its Slav population organized into a state with relations to the crown similar to those which Hungary now maintains. When the aged ruler is gathered to his fathers the worst that can happen would be something of that sort, because the centrifugal forces of disintegration will be more than counteracted by pressure from without. It must, therefore, be the task of Rumanian statesmen to curb the lively but uncertain aspirations of their people to enlarge the kingdom so that it will comprise within still greater frontiers all who claim to be Rumanians, including the great number inhabiting Transylvania under the rule of the Dual Monarchy. Nor will it be entirely easy to pacify her new subjects within the strategic frontier to the south, which she has recently acquired. Most of them are Turks and Moslems, while 
many are patriotic Bulgarians. It will be a matter of enormous expense to fortify this new frontier, to establish and enlarge her Black Sea commerce, to strengthen her already redoubtable army, and secure better relations with her powerful neighbor on the north.

The burdens which Servia must carry for years to come are even heavier. She has nearly doubled the extent of her territory, and to her lot it has fallen to regenerate the greater part of Macedonia, whose tribulations, already described, have almost completed the long process of annihilating all her resources, human and physical. The rich pasture lands are still there, but in the north they are held by Mohammedan Albanians, and in the south by Christian Bulgarians. The people of Novi-Bazar are Servian Moslems whose social station and organization make them as difficult of assimilation as the Albanians. Servia claims, of course, that the so-called Bulgarians of Macedonia are Bulgarized Serbs, who, if left undisturbed to her training, will in ten or fifteen years become enthusiastic Servians. In the meanwhile she has first to outlaw the komitadjis and bring the members of those cruel bands to trial and punishment; she has to lay before the exhausted villagers of Macedonia the choice between Servian and Bulgarian nationality, and more than all else, she has to lay the foundations for a permanent economic prosperity, by means of new transportation lines. She expects, when the Greek railway system is finally connected by way of Larissa and Salonica with that of the north, and when her own lines are put into satisfactory condition, that great numbers of tourists from the west will at least behold her natural beauties from car windows, and particu- 
larly that Rumanian commerce will use the new trunk line for easier access to the Mediterranean, and that thus by a substantial growth of freight and passenger traffic she will enormously increase her material prosperity. In case of a customs union with Montenegro she would have direct access to the Adriatic through Antivari and Dulcigno. The neglected fields of Macedonia must also be restored to tillage, what are still smoking ruins must once again be rebuilt for human habitation, and a more vigorous administration than she has hitherto practiced must be created and set in operation. In short, there must be a moral regeneration of her people on the civic side equal to that which it has undergone on the military. These are labors of Hercules. We can only hope that they can be performed by those to whom they are intrusted.

The task of Bulgaria is equally severe. Above all else, her courage must be resuscitated and her very life restored. Her exhaustion is more complete than that of any other of the recent combatants. What is possibly the most distasteful of all her endeavors will be the cultivation of helpful relations on one side with Austria-Hungary and on the other with her ruthless and embittered enemy Turkey. To win and keep the friendship of these states seems her only resource against further depredations. The Dual Monarchy, in spite of the creation of Albania, is dissatisfied with the settlement made at Bucharest and seems determined to prevent the solidification of existing conditions. It is afraid of the new and larger Servia. It is accused of secretly supporting Albanian disturbers on one of the Servian frontiers, while on the other the quarantine regulations and their enforcement are made as exasperating as possible. It like- 
wise claims a special rate for the transportation of its goods to Salonica. What is worst of all, it seems likely to demand a protectorate over Roman Catholics dwelling in Servia similar to that which it claims to exercise over Roman Catholics within the Albanian frontiers. Whether or not Servia, Montenegro, and Greece, with some assistance from Rumania, may be able to keep the peace would be a matter of doubt were it not for the prostration of Turkey and Bulgaria, both of which, though still warlike, are prone and panting and cannot be for long years very dangerous antagonists either by sea or by land.

Necessity laughs at theory: how far the antiquated principle of nationality, based on creed and language, has been disregarded appears from the map. The delimitation contemplated in the secret treaty scouted it entirely, as the sketch line shows. The boundaries tentatively fixed pay somewhat more attention to it, but still very little. The frontier between Turkey and Bulgaria begins north of Iniada on the Black Sea and by a westward curve ten miles or more from Adrianople reaches the Maritza River, which it follows to the Egean: in the northern portions of this segment the inhabitants are Bulgarians; in the southern they are Greeks, almost exclusively so on the Egean. By confession most of the people are Moslems, indeed overwhelmingly so.

The slight gain of Bulgaria on the Euxine is the valley of the Galadschio River with the port of Agathopoli: the population is Bulgarian and Christian in the main. The more substantial enlargement by the annexation of western Thrace to the south of the Egean coast from the mouth of the Maritza to that of the Mesta; and by the acquisition also of the inland 
valleys of the Mesta and Struma Rivers with the town of Strumnitza presents a very serious problem. Within these limits are numerous Greeks and some Turks: the people of northeastern Macedonia are Bulgarians and Christians eager to amalgamate with their kinsfolk. But the problem of the four hundred thousand Pomaks, Moslem Bulgarians of western Thrace, is most serious; their fanaticism is excessive, and thirty years ago they perpetrated the most frightful atrocities on their Christian kinsfolk. They stand now an unsolved enigma, and might, under contingencies easily imagined, largely neutralize the advantage gained by Bulgaria in securing an outlet to the Egean.

Many consider that Greece requires a period of recuperation quite as extended as that essential both to Bulgaria and Turkey. She has to maintain her preeminence by sea; she has to fortify and garrison the long and unscientific frontier recently acquired. In Salonica she has the most coveted harbor of the Egean; more than half of its one hundred and seventy-five thousand inhabitants are Spanish Jews not possible to be Hellenized; and were it not for the possible and probable financial assistance of her kinsfolk living elsewhere than in the enlarged Hellas, the possibility of assimilation would appear desperate.

On the mainland she has southern Epirus, but is forced to leave within the Servian frontier large numbers of her compatriots and withdraw her garrisons from their towns. This is likely to prove a cause of unceasing turmoil and an exasperation sure to arouse intermittent outbreaks of violence. She secures the hand-shaped peninsula of Chalcidice and the Macedonian shore. Her boundary begins east of Corfu, includes the Vozintza watershed, the entire Wistritza 
valley, and the inland south of Monastir. The inhabitants of these districts are largely Greek Christians, but there are many Moslem Vlachs on the uplands, numerous Greek Moslems in various communities, and a substantial number of both Albanians and Turks. By the contemplated disposal of the Egean islands she becomes an insular and of necessity a maritime power to an extent greater than ever. In Crete she has the key to the Egean. She will add to the many islands she already possesses Chios, Mitylene, Lemnos, Samothrace, and Tenedos, perhaps. Samos will maintain its autonomy and Thasos remains under Egyptian sway. Italian aspirations are momentarily quenched, but they are not annihilated. The tension with Turkey is such that in it there is still another standing menace to the peaceful solution of the troubles existing in the expansion of Hellenic power.

The reverse of this dreary outline, however, is to be found in the very helplessness of the Balkan powers. Like boys who have fought it out, they have a wholesome mutual respect one for the other, and their wounds, though not mortal, ache and will take long to heal. All the rest of Europe is weary of its increasing armaments. The experience which the great powers have so recently had, makes for better acquaintance among them and their peoples; for a higher degree of self-respect, and for the continuation of the general equilibrium, which, however nice in its adjustment, nevertheless exists. The problem of Turkey in Europe is largely solved. To permit any renewal of a warfare likely to disturb or destroy the existing solution would demand on the part of all other nations a still further burden of taxation and of intolerable extravagance for armies and 
fleets. The conclusion of the whole matter seems to be that this cannot and will not be permitted. The Balkan fires are likely to be banked for an age to come; the alembics are shattered, the instruments of precision, as they were considered, are racked and untrustworthy, the ghosts evoked by the witches' cauldron of their inept politics have been relegated to the limbo of extinction. In particular the dogma that nationality, ecclesiasticism, and consanguinity are the foundations of political efficiency has been discredited. 
क्ष 


\section{APPENDIX}

\section{Traité d'Amitié et d'Alliance \\ Entre le Royaume de Bulgarie \\ Et le Royaume de Serbie}

S. M. Ferdinand ${ }^{\mathrm{I}}$, roi des Bulgares, et S. M. Pierre Ier, roi de Serbie, pénétrés de la conviction de la communauté d'interêts et de la similitude des destinées de leurs Etats et des deux peuples frères, bulgare et serbe, et décidés à défendre solidairement, avec des forces communes, ces intérêts et à s'efforcer de les mener à bonne fin, sont convenus de ce qui suit:

\section{Article PRemier}

Le royaume de "3ulgarie et le royaume de Serbie se garantissent mutuellement leur indépendance politique et l'intégrité de leur territoire, en s'engageant d'une manière absolue et sans restriction d'aucune sorte à se porte réciproquement secours, avec la totalité de leurs forces, dans tout cas où l'un des deux royaumes serait attaqué par un ou plusieurs Etats.

ART. 2

Les deux parties contractantes s'engagent de même à se porter mutuellement secours, avec la totalité de leurs forces, au cas où l'une quelconque des grandes puissances tenterait de s'annexer, ou d'occuper, ou de prendre possession avec ses troupes, même provisoirement, de n'importe quelle partie des territoires de la péninsule des Balkans se trouvant actuellement sous la domination turque, si l'une des parties contractantes estime ce fait contraire à ses intérêts vitaux et constituant un casus belli.

\section{ART. 3}

Les deux parties contractantes s'engagent à ne conclure la paix que conjointement et après entente préalable.

\section{ART. 4}

Une convention militaire sera conclue à l'effet d'assurer l'exécution du présent traité d'une manière complète et le plus 
conforme au but poursuivi. Cette convention stipulera aussi bien tout ce qu'il y aura lieu d'entreprendre de part et d'autre en cas de guerre, que tout ce qui, ayant trait à l'organisation militaire, la dislocation et la mobilisation des troupes, les rapports des hauts commandements, devra être établi, dés le temps de paix, pour la préparation et la bonne conduite de la guerre.

La convention militaire fera partie intégrante du présent traité. Son élaboration devra commencer au plus tard quinze jours après la signature du présent traité et être terminée dans le délai suivant de deux mois.

\section{ART. 5}

Le présent traité et la convention militaire seront en vigueur du jour de leur signature jusqu'au 3I décembre 1920 inclusivement. Ils ne pourront être prorogés au delà de ce délai qu'après une entente complémentaire, expressément sanctionnée, des deux parties contractantes. Toutefois, au cas où au joụr de l'expiration du traité et de la convention militaire, les deux parties se trouveraient être en guerre où sans avoir liquidé encore la situation resultant de la guerre, le traité et la convention seront maintenus en vigueur jusqu'à la signature de la paix ou à la liquidation de l'état de choses amené par la guerre.

\section{ART. 6}

Le présent traité sera établi en deux exemplaires uniformes, rédigés tous les deux en langue serbe et bulgare. Il sera signé par les souverains et les ministres des affaires étrangères des deux Etats. La convention militaire, également en deux exemplaires rédigés en bulgare et en serbe, sera signée par les souverains, les ministres des affaires étrangères et les plénipotentiaires militaires spéciaux.

ART. 7

Le présent traité et la convention militaire ne pourront être publiés ou communiqués à d'autres Etats qu'après entente préalable des deux parties contractantes, et ce conjointement et simultanément.

Une entente préalable sera de même nécessaire pour l'admission d'un tiers Etat dans l'alliance.

Fait à Sofia, le 29 février 1912 
Annexe secrète au traité d'amitié et d'alliance entre le royaume de Bulgarie et le royaume de Serbie

\section{ArTiCle PREMier}

$\mathrm{Au}$ cas où des troubles intérieurs, de nature à mettre en danger les interêts nationaux ou d'Etat des parties contractantes ou de l'une d'elles, survenaient en Turquie, comme au cas où des difficultés intérieures ou extérieures avec lesquelles la Turquie se verrait aux prises mettraient en cause le maintien du statu quo dans la péninsule des Balkans, celle des deux parties contractantes qui aboutirait la première à la conviction qu'une action militaire doit être engagée de ce fait s'adressera, par une proposition motivée, à l'autre partie qui sera tenue d'entrer immediatement dans un échange de vues, et si elle ne tombe pas d'accord avec son alliée, de lui donner une réponse motivée.

Si une entente en vue d'une action intervient, cette entente devra être communiquée à la Russie, et au cas où cette puissance ne s'y opposerait pas, l'action sera engagée, conformément à l'entente établie et en s'inspirant en tout des sentiments de solidarité et de communauté d'intérêts. Dans le cas contraire - soit si une entente n'intervient pas-les deux Etats feront appel à l'opinion de la Russie, laquelle opinion sera, si et dans la mesure dans laquelle la Russie se prononcera, obligatoire pour les deux parties.

$\mathrm{Au}$ cas où la Russie s'abstenant de donner son opinion et l'entente entre les deux parties contractantes ne pouvant, même après cela, être obtenue, celle des deux parties qui est pour une action décide d'engager cette dernière à elle seule et à ses risques, l'autre partie sera tenue d'observer une neutralité amicale vis-à-vis de son alliée, de procéder sur-le-champ à une mobilisation dans les limites prévues par la convention militaire et de se porter, avec toutes ses forces, au secours de son alliée, si un tiers Etat prenait le parti de la Turquie.

\section{ART. 2}

Tous les accroissements territoriaux qui seraient réalisés par une action commune dans le sens des articles premier et second du traité et de l'article premier de la présente annexe secrète, tombent sous la domination commune (condominium) des deux 
états alliés. Leur liquidation aura lieu sans retard, dans un délai maximum de trois mois après le rétablissement de la paix, et sur les bases suivantes:

La Serbie reconnait à la Bulgarie le droit sur les territoires à l'est des Rhodope et de la rivière Strouma; la Bulgarie reconnait le droit de la Serbie sur ceux situés au nord et à l'ouest du Char-Planina.

Quant aux territoires compris entre le Char, les Rhodope, la mer Egée et le lac d'Ochrida, si les deux parties acquièrent la conviction que leur organisation en province autonome distincte est impossible en vue des intérêts communs des nationalités bulgare et serbe ou pour d'autres raisons d'ordre intérieur ou extérieur, il sera disposé de ces territoires conformément aux stipulations ci-dessous:

La Serbie s'engage à ne formuler aucune revendication en ce qui concerne les territoires situés au delà de la ligne tracée sur la carte ci-annexée et qui, ayant son point de départ à la frontière turco-bulgare, au mont Golem (au nord de $\mathrm{Kr}$. Palanka) suit la direction genérale du sud-ouest jusqu'au lac d'Ochrida, en passant par le mont Kitka; entre les villages de Metejevo et Podarji-Kon, par le sommet à l'est du village $\mathrm{Ne}$ rav, en suivant la ligne de partage des eaux jusqu'au sommet I.000 au nord du village de Baschtévo, entre les villages de Liubentzi et Petarlitza, par le sommet Ostritch 1.000 (LissetzPlanina), le sommet $\mathrm{I} .050$ entre les villages de Dratch et Opila, par les villages de Talichmantzi et Jivalevo, le sommet I.050, le sommet I.000, le village Kichali, la ligne principale de partage des eaux Gradichté-Planina jusqu'au sommet Gorichté, vers le sommet 1.023, suivant ensuite la ligne de partage des eaux entre les villages Ivankovtzi et Loghintzi, par Vetersko et Sopot sur le Vardar. Traversant le Vardar, elle suit les crêtes vers le sommet 2.550 et jusqu'à la montagne Petropole, par la ligne de partage des eaux de cette montagne entre les villages de Krapa et Barbarès jusqu'au sommet 1.200, entre les villages de Yakryenovo et Drenovo, jusqu'au mont Tchesma (I.254), par la ligne de partage des eaux des montagnes BabaPlanina et Krouchka-Tepessi, entre les villages de Salp et Tzerske, jusqu'au sommet de la Protoyska-Planina, à l'est du village de Belitza, par Bréjani, jusqu'au sommet 1.200 (IlinskaPlanina), par la ligne de partage des eaux passant par le sommet 1.330 jusqu'au sommet I.21 7 et entre les villages de Livoichta 
et Gorentzi jusqu'au lac d'Ochrida près du monastère de Gabovtzi.

La Bulgarie s'engage à accepter cette frontiére si S. M. l'empereur de Russie, qui sera sollicité d'être l'arbitre suprême en cette question, se prononce en faveur de cette ligne.

Il va de soi que les deux parties contractantes s'engagent à accepter comme frontière définitive la ligne que S. M. l'empereur de Russie, dans les limites susindiquées, aurait trouvée correspondre le plus aux droits et aux intérêts des deux parties.

ART. 3

Copie du traité et de la présente annexe secrète sera communiqué conjointement au gouvernement impérial de Russie, qui sera prié en même temps d'en prendre acte, de faire preuve de bienveillance à l'égard des buts qu'ils poursuivent, et de prier S. M. l'empereur de Russie de daigner accepter et approuver les attributions désignées pour sa personne et son gouvernement, par les clauses de ces deux actes.

ART. 4

Tout différend qui surgirait touchant l'interprétation et l'exécution d'une quelconque des clauses du traité, de la présente annexe secrète et de la convention militaire sera soumis à la décision définitive de la Russie, dès lors que l'une des deux parties aura déclaré qu'elle estime impossible une entente par des pourparlers directs.

ART. 5

Aucune des dispositions de la présente annexe secrète ne pourra être publiée ou communiquée à un autre Etat sans une entente préalable des deux parties et l'assentiment de la Russie.

Fait à Sofia, le 29 février 1912

\section{Convention Militaire}

Entre le Royaume de Bulgarie

et le Royaume de Serbie

Conformément à l'esprit et sur la base de l'article 3 du traité d'amitié et d'alliance entre le royaume de Bulgarie et le royaume de Serbie et afin de mieux assurer la conduite de la guerre avec succès et la réalisation plus complète des buts que l'alliance a en vue, les deux parties contractantes conviennent des stipula- 
tions ci-dessous, qui auront en tout même force et valeur que les dispositions du traité lui-même.

\section{ARTICLE PREMIER}

Le royaume de Bulgarie et le royaume de Serbie s'engagent, dans les cas prévus par les articles I et 2 du traité d'alliance et par l'article I de l'annexe secrète à ce traité, à se porter mutuellement secours, la Bulgarie avec une force armée qui ne devra pas être inférieure à deux cent mille combattants et la Serbie avec une force d'au moins cent cinquante mille combattants, en mesure aussi bien de combattre à la frontière que de prendre part à des operations militaires hors du territoire national.

Dans ce nombre ne sauraient être compris ni les combattants de formations surnuméraires, ni ceux du troisième ban serbe, ni les troupes territoriales bulgares.

Ce contingent de combattants devra être rendu à la frontière ou au delà des frontières de son territoire national-dans la direction où il devra être dirigé suivant les causes et le but de la guerre, et d'après le développement des opérations militairesau plus tard le $2 \mathrm{I}^{\mathrm{\theta}}$ jour après la déclaration de la guerre ou la communication de l'Etat allié que la casus foderis s'est produit. Toutefois, même avant l'expiration de ce délai, les deux parties considéreront comme leur devoir d'alliée-et si cela est conforme à la nature des opérations militaires et peut contribuer à l'issue favorable de la guerre-d'envoyer, même partiellement et dans les limites de la mobilisation et de la concentration, leurs troupes sur le champ de bataille dès le septième jour à partir de la déclaration de la guerre ou de la survenance du casus foderis.

ART. 2

Si la Roumanie attaque la Bulgarie, la Serbie est tenue de lui déclarer immédiatement la guerre et de diriger contre elle ses forces, d'au moins cent mille combattants, soit sur le moyen Danube, soit sur le théâtre d'opérations de la Dobroudja.

Au cas où la Turquie attaquerait la Bulgarie, la Serbie s'engage à pénétrer en Turquie et à distraire de ses troupes mobilisées, cent mille combattants au moins pour les diriger sur le théâtre d'opérations du Vardar.

Si la Serbie se trouve être à ce moment seule ou conjointement avec la Bulgarie, déjà en guerre avec un tiers Etat, elle 
engagera contre la Roumanie ou la Turquie toutes les troupes dont elle conservera la libre disposition.

ART. 3

Si l'Autriche-Hongrie attaque la Serbie, la Bulgarie est tenue de déclarer immédiatement la guerre à l'Autriche-Hongrie et de diriger ses troupes, d'au moins deux cent mille combattants, en Serbie, de telle sorte que, unies à l'armée serbe, elles opèrent soit offensivement, soit défensivement, contre l'Autriche-Hongrie.

La même obligation incombera à la Bulgarie vis-à-vis de la Serbie au cas où l'Autriche-Hongrie, sous quelque prétexte que ce soit, d'accord ou sans le consentement de la Turquie, fait pénétrer ses troupes dans le sandjak de Novi-Bazar et que par suite la Serbie lui déclare la guerre ou, pour la défense de ses intéréts, dirige ses troupes dans le sandjak et par là provoque un conflit armé entre elle et l'Autriche-Hongrie.

Au cas où la Turquie attaquerait la Serbie, la Bulgarie s'engage à franchir immédiatement la frontière turque et à prélever sur ses troupes, mobilisées conformément à l'article premier de la présente convention, une armée forte d'au moins cent mille combattants, qui sera dirigée sur le théâtre d'opérations $d \mathfrak{u}$ Vardar.

Si la Roumanie attaque la Serbie, la Bulgarie est tenue d'attaquer les troupes roumaines dès qu'elles auront pénétré, en traversant le Danube, sur le territoire serbe.

Si la Bulgarie, dans l'un quelconque des cas envisagés par le présent article, se trouve déjà, seule ou conjointement avec la Serbie, en guerre avec un tiers Etat, elle est tenue de porter au secours de la Serbie toutes les troupes dont elle conserverait la libre disposition.

ART. 4

Si la Bulgarie et la Serbie, suivant une entente préalable, déclarent la guerre à la Turquie, l'une et l'autre seront tenues, s'il n'en est disposé autrement par un arrangement spécial, de prélever sur leurs troupes, mobilisées conformément à l'article premier de la présente convention, et de diriger sur le théâtre d'opérations du Vardar une armée d'au moins cent mille combattants.

ART. 5

Au cas où l'une des parties contractantes déclarerait la guerre à un tiers Etat sans entente préalable et sans le consentement de 
l'autre partie contractante, cette dernière sera déliée des obligations prévues à l'article premier de la présente convention, mais sera tenue d'observer, pendant la durée de la guerre une neutralité amicale vis-à-vis de son alliée, ainsi que de mobiliser sans retard une force d'au moins cinquante mille combattants qui sera concentrée de manière à assurer au mieux la liberté des mouvements, de son alliée.

\section{ArT. 6}

En cas de guerre conjointe, aucune des parties contractantes ne pourra conclure avec l'ennemi d'armistice plus long que 24 heures, sans une entente préalable et sans le consentement de l'autre partie.

Une entente préalable et par écrit sera de même nécessaire pour que des pourparlers de paix puissent être engagés et un traité de paix signé.

\section{ART. 7}

Pendant la durée de la guerre, les troupes de chacune des parties contractantes seront commandées et toutes leurs opérations seront dirigées par leurs propres commandements.

Lorsque des corps de troupes appartenant aux armées des deux Etats opéreront contre un même objectif, le commandement commun sera pris, pour des unités de même importance, par le chef !e plus ancien en grade, et pour des unités d'importance différente par le chef le plus ancien au point de vue du commandement exercé.

Lorsqu'une ou plusieurs armées distinctes appartenant à une des parties contractantes seront mises à la disposition de l'autre partie, elles se trouveront sous les ordres de leurs propres commandants qui, pour la conduite stratégique des opérations, seront soumis au commandant en chef de l'armée à la disposition de laquelle elles sont mises.

En cas de guerre conjointe contre la Turquie, le commandement en chef sur le théâtre d'opérations du Vardar appartiendra à la Serbie si l'armée principale serbe opère sur ce théâtre et si elle est numériquement plus forte que les troupes bulgares sur ce théâtre conformément à l'article 4 de la présente convention. Toutefois si l'armée principale serbe n'opère pas sur ce théâtre et lorsqu'elle y sera numériquement plus faible que les troupes bulgares, le commandement en chef sur ce théâtre appartiendra à la Bulgarie. 
ART. 8

Au cas où les troupes des deux parties contractantes se trouveraient placées sous les ordres d'un même commandant, tous les ordres et toutes les prescriptions se rapportant à la conduite stratégique des opérations tactiques communes seront rédigées dans les deux langues-en bulgare et en serbe.

ArT. 9

En ce qui concerne le ravitaillement et les subsistances en général, le logement, le service medical, le transport des blessés et malades ou l'inhumation des morts, le transport du matériel de guerre et autres objets similaires, l'armée de chacune des parties contractantes jouira des mêmes droits et facilités sur le territoire de l'autre partie et par les mêmes procédés que les troupes de cette dernière partie, conformément aux lois et règles locales. Toutes les autorités locales doivent, dans le même but, prêter leur appui aux troupes alliées.

Le payement de toutes les subsistances sera réglé par chaque partie pour son compte aux prix locaux, de préférence en espèces et dans des cas exceptionnels contre bons délivrés spécialement.

Le transport des troupes et de tout le matériel de guerre, subsistances et autres objets en chemin de fer et les frais y relatifs seront à la charge de la partie sur le territoire de laquelle ce transport a lieu.

ART. Io

Les trophées appartiennent à l'armée qui les aura pris.

Dans le cas où la prise a lieu par l'effet d'un combat en commun sur le même terrain, les deux armées partageront les trophées proportionnellement aux forces des combattants qui $y$ auront directement participé.

ART. II

Durant la guerre, chaque partie contractante aura un délégué dans l'état-major du commandement en chef ou dans les commandements des armées, lesquels délégués entretiendront les liens entre les deux armées sous tous les rapports. 
ART. 12

Les opérations stratégiques et les cas qui ne sont pas prévus, ainsi que les contestations qui pourraient surgir seront réglés d'un commun accord par les deux commandements en chef.

\section{ART. I3}

Les chefs des états-majors des armées alliées s'entendront, immédiatement après la conclusion de la présente convention, sur la distribution des troupes mobilisées d'après l'article premier de cette convention et leur groupement dans la zone de concentration dans les cas exposés ci-dessus, sur les routes qui devront être réparées ou construites de nouveau en vue de la concentration rapide sur la frontière et les opérations ultérieures.

ART. I4

La présente convention sera en vigueur à partir du jour de sa signature et durera tant qu'aura force le traité d'amitié et d'alliance auquel elle est annexée à titre de partie intégrante.

\section{Arrangement entre les états-majors de Bulgarie et de Serbie}

Conformément à l'article $\mathrm{I} 3$ de la convention militaire existant entre le royaume de Bulgarie et le royaume de Serbie, les délégués désignés par les deux parties ont, sur la base des plans d'opérations respectifs, convenu de ce qui suit:

Au cas d'une guerre entre la Bulgarie et la Serbie d'une part et la Turquie de l'autre:

Dans l'hypothèse où la principale armée turque serait concentrée dans la région d'Uskub, Koumanovo, Kratovo, Kotchani, Velès, les troupes alliées destinées à agir sur le théâtre d'opérations du Vardar seront réparties comme suit:

$\mathrm{I}^{0}$ Une armée serbe de deux divisions marchera, par le KaraDagh, sur Uskub. Cette armée formera l'aile droite des troupes alliées ;

$2^{0}$ Une armée serbe de cinq divisions d'infanterie et une division de cavalerie avancera, par la vallée de la Moravitza et de la Ptchinia, sur le front Koumanovo-Kratovo. Cette armée constituera le centre des troupes alliées avec la mission d'opérer de front contre l'ennemi; 
$3^{0}$ Une armée bulgare de trois divisions formera l'aile gauche des troupes alliées, avec la mission d'opérer contre l'aile droite et sur les derrières de l'ennemi, dans les directions de KustendilEgri-Palanka-Uskub et Kustendil-Tzarévo-Sélo-Kotchani.

$4^{\circ}$ Les deux chefs d'état-major général reconnaitront ensemble la région entre Kustendil et Vrania, et si cette reconnaissance démontre le possibilité d'employer de grandes masses dans la direction Kustendil-Egri-Palanka-Uskub, les deux divisions serbes destinées à opérer, par le Kara-Dagh, contre Uskub, seront, si la situation générale le permet, employées à renforcer l'aile gauche des troupes alliées et seront concentrées à cet effet près de Kustendil.

$5^{\circ}$ Pour couvrir le flanc droit des troupes alliées, le chef d'état-major de l'armée serbe disposera à sa convenance des trois divisions restantes du deuxième ban.

$6^{\circ}$ Le chef d'état-major de l'armée bulgare s'engage à agir pour la prompte mise en état de la route de Bossilegrad à Vlassina.

$7^{\circ} \mathrm{Si}$ la situation exige le renforcement des troupes bulgares sur le théâtre d'opérations de la Maritza et si, pour le théâtre d'opérations du Vardar, toutes les troupes ci-dessus énumérées ne sont point indispensables, les unités nécessaires seront transportées de ce dernier théâtre d'opérations sur celui de la Maritza. A l'inverse, si la situation exige le renforcement des troupes alliées sur le théâtre d'opérations du Vardar et si le maintien de toutes les troupes désignées pour les opérations sur le théâtre de la Maritza n'est pas indispensable, les unités nécessaires seront transportées de ce thêâtre sur celui du Vardar.

\section{Annexe}

Les deux états-majors généraux s'engagent:

a) A échanger tous leurs renseignements sur les armées des pays limitrophes;

b) A se procurer mutuellement le nombre voulu d'exemplaires de tous les règlements, instructions, cartes, etc., tant officiels que secrets;

c) A envoyer chacun dans l'armée alliée un certain nombre d'officiers chargés de se familiariser avec son organisation et d'en étudier la langue, conformément à l'art. II de la convention militaire.
d) Les chefs d'état-major des armées serbe et bulgare se 
rencontreront chaque automne pour se mettre au courant de la situation générale et pour introduire dans les arrangements conclus les modifications rendues nécessaires par les changements de la situation.

Varna, 19 juin 1912

Général R. Poutnik, Général Fitchfrf.

\section{Traité d'Alliance Defensive \\ Entre la Bulgarie et la Grèce}

Considérant que les deux royaumes désirent fermement la conservation de la paix dans la péninsule balkanique et peuvent, par une alliance défensive solide, mieux répondre à ce besoin:

Considérant, dans ce même ordre d'idées, que la coexistence pacifique des différentes nationalités en Turquie, sur la base d'une égalité politique réelle et véritable et le respect des droits découlant des traités ou autrement concédés aux nationalités chrétiennes de l'empire, constituent des conditions nécessaires pour la consolidation de l'état de choses en Orient;

Considérant enfin qu'une coopération des deux royaumes, dans le sens indiqué, est de nature, dans l'intérêt même de leurs bons rapports avec l'empire ottoman, à faciliter et à corroborer l'entente des éléments grec et bulgare en Turquie;

Le gouvernement de Sa Majesté le roi des Bulgares et le gouvernement de Sa Majesté le roi des Hellènes, se promettant de ne pas donner une tendance agressive quelconque à leur accord purement défensif et ayant résolu de conclure une alliance de paix et de protection réciproque dans les termes ci-dessous indiqués, ont nommé pour leus plénipotentiaires. . .

Lesquels, après avoir échangé leurs pleins pouvoirs, ont arrêté ce qui suit:

\section{Article premier}

$\mathrm{Si}$, contrairement au sincère désir des deux hautes parties contractantes, et en dépit d'une attitude de leur gouvernement évitant tout acte d'agression et toute provocation vis-à-vis de l'empire ottoman, l'un des deux Etats venait à être attaqué par la Turquie, soit dans son territoire, soit par une atteinte systématique aux droits découlant des traités ou des principes fondamentaux du droit des gens, les deux hautes parties con- 
tractantes sont tenues à se prêter réciproquement secours avec la totalité de leurs forces armées et par suite à ne conclure la paix que conjointement et d'accord.

ART. 2

Les deux hautes parties contractantes se promettent mutuellement, d'un côté d'user de leur influence morale auprès de leurs congénères en Turquie afin qu'ils contribuent sincerement à la coexistence pacifique des éléments constituant la population de l'empire, et de l'autre côté de se prêter une assistance réciproque et de marcher d'accord, dans toute action, auprès du gouvernement ottoman ou auprès des grandes puissances, qui aurait pour but d'obtenir ou d'assurer la réalisation des droits découlant des traités ou autrement concédés aux nationalités grecque et bulgare, l'application de l'égalité politique et des garanties constitutionnelles.

\section{ART. 3}

Le présent traité aura une durée de trois ans à partir du jour de sa signature et sera renouvelé tacitement pour une année sauf dénonciation. Sa dénonciation doit être notifiée au moins six mois avant l'expiration de la troisième année à partir de la signature du traité.

\section{ART. 4}

Le présent traité sera gardé secret. Il ne pourra être communiqué à une tierce puissance soit intégralement, soit en partie, ni divulgué en partie ou en tout qu'avec le consentement des deux hautes parties contractantes.

Le présent traité sera ratifié le plus tôt que faire se pourra. Les ratifications seront échangées à Sofia (ou à Athènes).

En foi de quoi, les plénipotentiaires respectifs ont signé le présent traité et y ont apposé leurs cachets.

Fait à Sofia, en double expédition, le I6 mai 1912

I. E. Guéchoff, D. Panas.

\section{DÉClaration}

L'article $I^{\text {er }}$ ne se rapporte notamment pas au cas où une guerre viendrait à éclater entre la Grèce et la Turquie par suite de l'admission dans le Parlement grec des députés crétois contre la volonté du gouvernement ottoman; dans ce cas, la Bulgarie n'est tenue qu'à garder vis-à-vis de la Grèce une neutralité bien- 
veillante. Et comme la liquidation de la crise des affaires d'Orient, née des événements de I908, aussi quant à la question crétoise, correspond à l'intérêt général, et est même de nature, sans troubler l'équilibre dans la péninsule balkanique, à y consolider dans l'intérêt de la paix la situation internationale, la Bulgarie (indépendamment des engagements assumés par le présent traité) promet de ne gêner d'aucune façon une action éventuelle de la Grèce qui tendrait à la solution de cette question.

I. E. GuÉchoff, D. Panas.

\section{Convention Militaire}

S. M. le roi des Bulgares et S. M. le roi des Hellènes, désirant complèter par une convention militaire le traité d'alliance défensive conclu à Sofia le I6 mai IgI2 entre le royaume de Bulgarie et le royaume de Grèce, ont, dans ce but, nommé pour leurs plénipotentiaires:

Sa Majesté le roi des Bulgares:

Son Exc. M. Iv. Ev. Guéchoff, etc., etc.

Sa Majesté le roi des Hellènes:

Son Exc. M. D. Panas, etc., etc.

Lesquels après s'être communiqué leurs pleins pouvoirs trouvés en bonne et due forme, sont convenus de ce qui suit:

\section{ARTICLE PREMIER}

Dans le cas où, conformément aux obligations découlant du traité d'alliance défensive conclu à Sofia le I6 mai I9I2 entre la Bulgarie et la Grèce, la Grèce interviendrait militairement contre la Turquie dans une guerre bulgaro-turque, ou bien la Bulgarie contre la Turquie dans une guerre turco-grecque, les deux Etats, bulgare et grec, s'engagent à se prêter mutuellement secours, soit la Grèce avec un effectif atteignant au minimum cent vingt mille hommes, et la Bulgarie avec un effectif d'au moins trois cent mille hommes; ces forces devront être aptes aussi bien à entrer en campagne sur la frontière qu'à prendre part à des opérations militaires en dehors des limites du territoire national. 
Les troupes susindiquées devront être concentrées à la frontière et à même de la franchir au plus tard le vingtième jour qui aura suivi la mobilisation ou l'avis donné par l'une des parties contractantes que le casus federis s'est produit.

\section{ART. 2}

Au cas où la Grèce viendrait à être attaquée par la Turquie, la Bulgarie s'engage à déclarer la guerre à cette dernière puissance et à entrer en campagne contre elle avec l'ensemble de ses forces, fixées, au terme de l'article premier, à un minimum de trois cent mille hommes, en conformant ses opérations militaires au plan élaboré par l'état-major bulgare.

$\mathrm{Au}$ cas où la Bulgarie viendrait à être attaquée par la Turquie, la Grèce s'engage à déclarer la guerre à cette dernière puissance et à entrer en campagne contre elle avec l'ensemble de ses forces, fixées, aux termes de l'article premier, à un minimum de cent vingt mille hommes, en conformant ses opérations militaires au plan élaboré par l'état-major grec. L'objectif principal de la flotte hellénique devra toutefois être de se rendre maitresse de la mer Egée et d'interrompre les communications par cette voie entre l'Asie-Mineure et la Turquie d'Europe.

Dans les cas prévus aux deux paragraphes précédents, la Bulgarie s'engage à opérer offensivement avec une partie importante de son armée contre les forces turques concentrées dans la région des vilayets de Kossovo, Monastir et Salonique. Si la Serbie, en vertu de ses accords avec la Bulgarie, prend part à la guerre, la Bulgarie pourra disposer de la totalité de ses forces militaires en Thrace, mais dans ce cas elle prend par le présent acte l'engagement envers la Grèce que des forces militaires serbes d'un effectif d'au moins cent vingt mille combattants opèreront offensivement contre les forces turques concentrées dans la région des trois vilayets susmentionnés.

\section{ART. 3}

Si la Bulgarie et la Grèce, aux termes d'une entente préalable, déclarent la guerre à la Turquie, elles sont l'une et l'autre tenues -à moins qu'il n'en soit disposé autrement par un accord spécial -de faire entrer en campagne les effectifs prévus à l'article premier de la présente convention. 
Les dispositions de deux derniers paragraphes de l'article 2 sont dans ce cas aussi applicables.

\section{ART. 4}

$A u$ cas où l'un des gouvernements contractants déclarerait la guerre à un Etat autre que la Turquie, sans une entente préalable et sans le consentement de l'autre gouvernement, ce dernier est délié des obligations exposées à l'article premier, mais reste néanmoins tenu d'observer, pendant toute la durée de la guerre, une neutralité amicale à l'égard de son allié.

\section{ART. 5}

En cas de guerre conjointe, aucun des Etats alliés ne pourra conclure d'armistice d'une durée supérieure à vingt-quatre heures, sans une entente préalable et sans le consentement de l'autre Etat allié.

L'entente des deux parties contractantes, contenu dans un accord écrit, sera de même nécessaire pour que l'une d'elles puisse engager des négociations en vue de la paix ou conclure un traité de paix.

\section{ART. 6}

Dans le cas où la Bulgarie et la Grèce ayant mobilisé leurs forces armées ou étant entrées en campagne, la Grèce se verrait obligée de régler la question crétoise suivant les vœux des populations de l'île et serait pour cela attaquée par la Turquie, la Bulgarie s'engage à se porter à son secours, conformément à l'article premier de la présente convention.

\section{ArT. 7}

Les chefs d'état-major général des armées bulgare et grecque devront se renseigner mutuellement et en temps opportun sur leurs plans d'opérations en cas d'une guerre. Ils devront en outre faire connaitre tous les ans les modifications apportées à ces plans du fait de circonstances nouvelles.

\section{ART. 8}

La présente convention deviendra obligatoire pour les deux parties contractantes sitôt après avoir été signée; elle demeurera en vigueur pendant toute la durée du traité d'alliance défensive 


\section{APPENDIX}

du 16 mai 1912, auquel elle est incorporée à titre de partie intégrante.

Fait a Sofia, en double exemplaire, le 22 septembre 1912

I. E. Gúchorf,

Général Frtchers.

D. Panas,

J. P. MÉtaXes, capitaine. 

INDEX

3I3 



\section{INDEX}

Abdul Hamid, secluded life of, 29; refused recognition by millions, 29; cited, 43; an accomplished opportunist in politics, 43; cares of, 45; bitterness of toward Great Britain, 46; unseated and sent a prisoner to Salonica, 85; Oriental despotism practiced by, I47

Abdul Medjid, cited, r2o

Adams, John Quincy, quoted, $24 \mathrm{I}$

Adrianople, invested by Bulgarians, 166; keeping of under Turkish rule, 179, 247

Egean Isles, different peoples occupying the, 100; importance of Greek inhabitants in, Ior; perplexing situation relative to, 245; held by Italy, 282

Albanians, no question as to their essential unity, 42; a riddle, 75 ; generally accepted hypothesis of origin of, 77 ; independent of religion in personal conduct, 78; physical and mental characteristics of, 78; language and original character retained by, Ior; nationality asserted by, r9o

Alexander I of Servia, consort chosen by, I4I; assassinated, I4I ; penalties paid by murderers of, 143

Alexander I of Russia, enthronement of, ro; death of, 106

Alexander the Great, effect of his triumphs on the conquered, 58

Alexander Ypsilanti, proclamation issued by, 105
Alfred, Prince, chosen to succeed King Otto of Greece, I09

Algeciras Conference, cited, 85 Ali, just succession of prevented, 46

Ali Saib, celebrated Turkish general, defeated, 95

Allies, success of, 165 ; war cry of, 169; all Turkey in Europe in possession of, 172 ; discord among the, I73

America, being made unilingual and homogeneous, 35

Anastasius, defeated by the Slavs, 65

Armament, some figures relative to, I76

Armistice of Bulair, signing of, 174

Aryans, cited, 34; theoretical reconstruction of, 36 ; term defined, 40

Ashkenazi Jew, the, cruelties inflicted upon, 33

Asia Minor, ethnic stocks of, 3; massacre of Christians in, I57; railway lines in, 267

Athens, two views of, II2

Austria-Hungary, annexation of Bosnia and the Herzegovina by, I89; discussed, 254

Bajazet I, defeat and exile of, Bajazet II, reign of described, Io

Balkan Alliance, formation of, I83; believed once to be impossible, r86; military arrangements of, 202

Balkan peninsula, composition of, 3 ; prehistoric man in the, 55 ; earliest traceable immi- 
gration of settlers into, 57 ; an important migration into, 64 ; invasion of the by Avars, 65 ; principle of nationality in, 183

Balkan peoples, stage of development reached by, III ; twenty years of diplomacy among, I86; united by common suffering, 192

Balkan States, by whom inhabited, 4 ; of to-day, story of, r4; revival of trade in, 88 ; populations of, $\mathrm{I} 5 \mathrm{I}$; apportionment of surrendered territories an acute question in, I75; the term "nationality" in, 249; Islam in the, 264 ; nationality of uncertain, 274; elements of disunion in, 275 ; possible advance of in nationality, 277; armed peace in, 278

Bartlett, Ashmead, quoted, 226

Belgrade, palace scandals of, I42

Berlin Exchange, panic on, 177

Bouchier, quoted, 203; cited, 209, 219

Bryce, James, suggestion of, I83

"Bulgar," synonymous with "vulgar," ro3

Bulgaria, only permitted language in church and school in, I02; literary remains of burned, ro3; Prince Ferdinand made ruler of, I30; court and people discussed, I3I, I32; advantage possessed by, 150; independence declared by, I55; task faced by, 288; final abdication of Alexander as ruler of, 130 ; rulership of offered to and declined by Prince Waldemar of Denmark, I30

Bulgarian Church, secession of from control of Greek patriarchate in Constantinople, I27
Bulgars, Asiatic race called the, 40; nearest kin to the Turks, 66; founders of a mighty empire, 67; attached to Greek Catholic Church, 7I ; ambitions to control the Balkan peninsula, 7r; originally an Altaic horde, 72; physique described, 72 ; regarded as a dangerous element in Macedonia, 200

Byron, Lord, amazing verse of, 106; death of, 106

Canning, decisive step taken by, 106; death of, 107

Capitulations, cited, 17

Carnegie Peace Foundation, cited, 225

Carol, King, cited, 28I

Cavour, cited, 84

Cettigne, capital of Montenegro, described, 95 ; language spoken in, 96

Charles of Hohenzollern-Sigmaringen, Prince, chosen king of Rumania, I2I

Chieftains, government established and maintained by, 57; overthrown, 58

Christians, Byzantine type of, 37

Committee of Union and Progress, accomplishments of, I53; attempt to destroy power of, I57; composition of, I6I

Conflagration, European, danger of, 163

Congress of Vienna, cited, ${ }^{0} 4$

Constantine of Greece, King, cited, 28I

Constantine the Great, cited, 4

Constantinople, under Ottoman rule, 3 ; nationalities in, 4 ; fall of, I5; class of officials ruling at, and an example, 30; conquerors of never sure of their position in Christian world, 102; 
Greek patriarch at, 102; ascendancy regained by, 154

Cousa, acknowledged as Alexander John I, 120

Crete, rebellion of, I09; union with Greece voted by, 156

Crimean War, beginning of, II9

Cuba, cause of transformations in, 84

Customs system of Turks, analyzed, 28

Czar Peter the Great, victorious alliance formed by, 92

Czar Simeon, cited, I4

Czar Stephen-Dushan, cited, I4; achievements and death of, 68; climax of Servian strength reached under, I35

Daneff, prime minister, cited, 230

Danilo I of Montenegro, great accomplishments of, 93; defeat of Omar Pasha by, 94; assassinated by one of his own subjects, 94

Dardanelles, closing of, I6I

David, last so-called "Roman" ruler, cited, 5

Decibalus, King, power of annihilated, 62

Derwish, Turkish general, cited, 94

Diocletian, cited, 4

Diplomacy, European, awakened, 49

Disraeli, action of, 19

Draga, death of, I4I

Dual Monarchy, domination of in economic matters, 149; cited, 286

East Roman, or Byzantine, empire, fall of, 4; other names applied to, 39 ; language of, 39

East Rumelia, move to incorporate with Bulgaria, I28; Prince Alexander appointed governor-general of, I29
Emperor, East Roman, described, 6; his form of government, 7

Enver Bey, action of, 169

Europe, southeastern, nationalities of, 3 ; an ethnological museum, 3; described; 83; Western, types strongly developed in, 36

Feudalism, a social and economic system, I5

France, discussed, 259

Francis I, treaty concluded by, I6

Francis Joseph, cited, 286

Garibaldi, cited, 84

Genthios, King, defeated and captured, 59.

George, late king of the $\mathrm{Hel}$ lenes, discussed, II I

Germany, discussed, 258

Ghegs, the, national heroes furnished by, 77

Ghika, reform efforts of, II9

Goths, settlement of, 63 ; in Albanian Alps, 77

Grand Council of the Ottoman empire, summoning of, I69

Great Britain, profits pocketed by, 212 ; discussed, 260

"Great Idea," defined, 38; the common tie of colonist Albanians and native Greeks, IOI; determinative role of in Eastern Europe, II7; cited, I86, 235

"Great Servia" idea, the, I39

Greco-Bulgarian treaty, statement of, 197

Greece, progress of, 38 ; tactical mistakes made by, 38 ; modern, why called Slavic. 40 ; varying elements of population comprising, $4 \mathrm{I}$; becomes the province of Achaia, 60; the effect of Roman influence on, $6 \mathrm{I}$; Roman citizenship conferred on all freemen, $6 \mathrm{r}$; inde- 
pendence of declared by Powers, I07; declared a hereditary monarchy by London Conference, 108; story of consolidation of, I08; present peace and good order in, II2; German influence seen in, II3; plight of in 1908,150

Greek Assembly, the, first meeting of, 106; king selected by, I07

Greek Church, the, ramifications of its ecclesiastical order, I3; created by Greeks, IOI

Greeks, modern, from whom descended, 38 ; loss of political independence of the, 59; assisted by Albania in struggle for liberty, 99; dress of, 99; wholesale massacres of in island of Chios, I06; persecuted by Bulgaria, 188

Gregory X, cited, I6

Grey, Sir Edward, cited, I74; declaration of, 226

Gueshoff, policy of, 194

Gypsies, the, generally nomadic, 79

Hapsburgs, cited, I6

Hellenes, a cherished idea of, I04

Holy League, purpose of, I6

Hungarians, entrance of into Slavic territory, 67; remarkable civilization developed by, 67

Hungary, emancipated from Turkish rule, I33

Hunyadi, victories of, 9

Ignatieff, campaigns of, cited, I9

International Commission of Control, composition of, I8o Invaders, Turkish, in Asia, 5 Ionian Isles, ceded to Greece by Great Britain, 109
Ionians, cited, 55

Italy, Tripoli, and Cyrenaica occupied by, 159; fears of, I60

Ivan the Terrible, cited, I6

Janissaries, described, I2

Japhetites, cited, 34

Javanes, cited, 34

Jews, the, cited, I3; those of Ashkenazi branch hated and feared, 79; those of Sephardim branch generally respected, 80

Justinian, extension of Roman power under, 5; system of fortifications inaugurated by, 65

Kanaris, victory of, 106

Kapo d'Istrias, plenipotentiaries won to Greek cause by, I04; belief concerning, I07; assassinated by fellow patriots, 107

Karageorge, assassination of, I37

Karageorgevich, Alexander, chosen ruler of Servia, I38; deposed, I39

Leopold of Saxe Coburg, selected as king of Greece and declines, 107

Levant, the, destiny of, $5 \mathrm{I}$

Lewis I, King, cited, I08

Littmann, Professor, cited, 267

London Conference, action of relative to Greece, 108

Macedonia, woes and sorrows and cruelties in, 4I ; heterogeneous population of, $4 \mathrm{I}$; lines of division in, 43 ; atrocities in mainly the work of Christians, 49; demands an end of rapine and murder, 88 ; program for regeneration of, I48; futile efforts for reform in, I88; harmony among Christian races in, 
I9I ; murders of Christian leaders in, 194; revolt of Bulgarians in, I99; lawlessness in, 214; description of refugees from, 215 ; autonomy in opposed by Greece, $23 I$

Mahomet II, East Roman empire crushed by, Io; further victories and death of, Io

Marshall von Bieberstein, British influence nullified by, I53

Martel, Charles, cited, I5

Maximilian I, plan of for partition of Turkey, I6

Mazzini, cited, 84

Mehemet Ali of Egypt, existence of Turkey threatened by, I8; help of sought by Sultan, 106

Metternich system, Europe weary of, 106

Mexico, transformations in, 84

Miaulis, Admiral, own fleet destroyed by, 107

Milan, king of Servia, war declared by, 129

Milan IV, reign of 140 ; abdication of, I4I

Milyukoff, Professor, cited, 225

Mohammedanism, modified by Occidental influences, I4; spirit of equality in, 269

Montenegrins, possessed of primitive virtues, 70

Montenegro, physical features of, 89; aim and aspiration of, 9I ; good will of important to Turkey, 94 ; area and population of, 97 ; industries in, 97; army system of, 98; slight achievements of, 234

Morocco, cited, 85

Moslem law, protection from injurious administration of, I7

Müller, William, influence of in Germany, 106

Murad I, cited, 9; death of, 9

Murad II, victories of, 9
Napoleon, march of to Moscow, II8

Napoleon III, discernment of, 120

Napoleonic epoch, condition of Turkey during, i 8

Nationality, Slavic ideas of, 50

Navarino, battle of, I07

New Byzantium, restoration of postponed, 4I

Nicholas of Montenegro, reviving ambition of, 89; task faced by, 94 ; peace acquired by, 94 ; victories of, 95

Nicholas I of Russia, hostile to Austrian leadership, I06

Nicholas Ypsilanti, army of destroyed, I05

Obrenovich, Milosh, revolt inaugurated by, I37; abdication of, 138 ; recalled to throne, I39

Oghusians, cited, 8

Omar, Turkish general, cited, 94

Orchan, cited, 9

Osman, Othman, or Ottoman, founder of his line, cited, 8

Otto of Bavaria, crown of Greece offered to, I08; his throne declared vacant while absent, I09

Ottoman empire, administration of the, 13; integral part of European state system, I7; ignorance of conditions prevalent in twenty years ago, 24

Pan-Slavism, folly of illustrated, 208

Parthians, cited, 56

Pasha Kara-Mahmoud, defeat of by Peter I, 92

Paul, murder of in Saint Petersburg referred to, Io

Peace movement, dimensions assumed by, 273

Peace, partial accomplishment of, I72 
Pelasgians, a fabulous people, cited, 64

Peoples, European, once subject to Turkey, 34

Peter of Servia, King, enthronement of, 142

Peter II of Montenegro, an amazing personage, 93

Phanar, a quarter of Constantinople, cited, 37

Phanariotes, qualities of, 37

Philip of Flanders, throne of Rumania offered to and declined by, I2I

Philip II of Macedon, strong will of, 58

Pliny, Slavs mentioned by, 66

"Powers," the, attitude and temper of, 24I ; agreements of, 242 ; delicate relations of, 279

Prenk-Bib-Doda, cited, 77

Punic War, the second, cited, 59

Rayahs, little interested in nationalities of, 37

Reformation, the, cited, I6

Ristitch, Servian statesman, suggestion of, I84

Roman empire, rise of the, 59

Rumania, present kingdom of, $4 \mathrm{I}$; plan of for aggrandizement, 88; provinces united to form, I03; brilliant chapter in history of, I23; at war, I24; capital city of described, I25; social and economic questions solved by, I 26

Rumanian, garb of, 55 ; divergence of opinion as to ethnic character of the, 6I; physical differences noted, 62

Rumelia, portion of Bulgaria known as, 43

Russia, aims of, I7; wants Constantinople, I7; Napoleon's seizure of Egypt abhorrent to, I8; forced to support Turkey, I8; Czar of, his assumption of protectorate over Greek Christians in Palestine, I8; political influence of in the Balkans, 19; the persistently embittered foe of Turkey, I05

San Stefano, treaty of, cited, I9

Savoff, General, cited, I64, 230

Scander Beg, cited, 9; a national hero, 77; intolerable rule of, 9I

Scipio, L. victory of over Dalmatians, 59

Scutari, entrance of by King Nicholas, I7I ; taken possession by the Six Powers, I74

Scythians, what the word designates, 56

Secret treaty, called a conspiracy, 224

Selamlik, the, nature of, 29

Selim I, cited, Io

Selim II, cited, I I

Seljuke Turks, settlement of in Asia Minor, 4; discussed, 8

Serbo-Bulgarian treaty, provision of, 201

Serbo-Croats, general designation of Slavs, 69; physical qualities noted, 69; improvement of under Austro-Hungarian rule, 70 ; in Albanian Alps, 77

Servian Church, subordinated to patriarchate at Constantinople, I02; recognized as independent, I 35

Servia, rise of, I33, I34; factional quarrels in, I36; defeat of by Bulgaria, I40; corruption in public life in, I42; statesmen produced by, I84; principal industry of, 200 ; burdens to be borne by, 287

Shiite Persians, the, aversion of to Sunnite orthodox, 46 
Sigismund II, cited, 16

Sixtus V, cited, I6

Sobieski, John, cited, 5

Soleiman II, military successes of, II ; death of, II

Soleiman Khan, cited, 8

Soleiman, renowned Turkish general, repulsed, 95

Stambuloff, rise of, 130 ; assassination of, I3O

Stephanove, Professor, quoted, 224

Stephen, guerilla warfare of, 9I

Stone, Miss, capture of, 214

Stratford de Redclyffe, Lord, cited, 46

Sturdza, improvements sought by, II9

Sublime Porte, the, sobriquet of, I5; promises made by, 42

Sultan Abdul Aziz, boundary settled by, 94

Sultans, concessions secured from, 17

Teutons, the conquering, 28

Thracians, the, described, 55

Trajan, death of, cited, 63

Transylvania, cited, 286

Treaties made with the Porte, I7

Treaty of Berlin, made only to be violated, I9; parts of Albania ceded by to Nicholas, 96 ; cited, $147,148,155$, I60, I84, I85, 203, 21 I

Treaty of Bucharest, terms of settlement of, I78; cited, 247; criticism of, 248

Treaty of Constantinople, line established by, I79

Treaty of Kutschuk-Kainardje, what it established, II7

Treaty of Lausanne, signing of, I6r ; disposition of Agean Isles by, 245; full validity acquired by, 283

Treaty of London, determinations of, 246 ; original inten- tions of largely set aside, 247

Treaty of Paris, restorations of, II9

Treaty of peace, the, 228

Tricoupis, Greek statesman, hope of, 185

Triple Alliance, cited, 152, 158, 228, 280, 281

Triple Entente, cited, 158, 228

Turanians, cited, 36

Turkey, Russia a watchful foe of, I7; released from bondage by Crimean War, I9; in Europe, former boundaries of, 23 ; subject populations of, 33; decline and fall of, I28; declaration of war by, I63

Turkification, process of, 159; cited, 209; work of begun in Macedonia, 2I2; where forced to desist from, 2I3

Turkish rule, survival of, 32

Turks, courageous explorers and fighters, 7; supplant Byzantine administrators in Europe, 8; virtues retained by, 25; fine qualities exhibited by, 26; characteristics of, 26 ; women-folk of, 27 ; divorce among, 27; treatment of beggars by, 27; childish behavior of, 28; appearance of the in Balkan peninsula, 68 ; racial qualities of, 68

United States, process of assimilating all types of humanity in, 25I

"United States of Europe," a, suggested by idealists, 284

University of Athens, brilliancy of the, 60

Venezelos, good judgment of, I93; proposition submitted by, 195; efforts of for peace, 280

Victoria, Queen, cited, I09

Vlachs, a contingent in Macedonia, 42; called also Wal- 
lachs and Kutzovlachs, vagabond tendencies of, physical characteristics of, 73 ; distinctive dress of, 74

War, cause of in the Balkans, 35 ; second stage of, 170 ; between Italy and Turkey, 196 ; latest, national characteristics in, 207; conditions before the, 209; atrocities of, 2I7-223

Wellington, Duke of, agreement negotiated by, I06

Westphalia, treaty of, cited, I7

West, social order familiar to, I IO

William, Emperor, of Germany, cited, I I3
William Frederick of Wied, Prince, chosen ruler of autonomous Albania, I80

William, Prince, of Denmark, chosen king of the Hellenes, I09

World movement, what dependent upon, I7

Young Turks, hopeless effort of, 78; mobilization of armies by, 85 ; elaborate plan of, 86 ; reverses of, I56; amnesty granted by, I59; revolution of based on chimera, I88; suppression of atrocities perpetrated by, 209

Young Turk Revolution, how regarded, I55; no real change wrought by, 200 






\section{PLEASE DO NOT REMOVE CARDS OR SLIPS FROM THIS POCKET}

\section{UNIVERSITY OF TORONTO LIBRARY}

DR

45

558

Sloane, William Milligan

The Balkans 


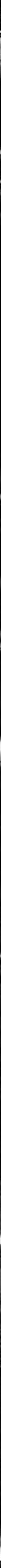

